ORNL- -6718

DE93 002621

\author{
Foisil Energy Program
}

FOSSIL ENERGY PROGRAM SEMIANNUAL PROGRESS REPORT FOR OCTOBER 1990 THROUGH MARCH 1991

R. R. Judkins

Program Manager

Date Published: July 1992

Prepared for the

DOE Office of Fossil Energy

(AA 000000 0)

Prepared by the

OAK RIDGE NATIONAL LABORATORY

Oak Ridge, Tennessee 37831-6285

managed by

MARTIN MARIETTA ENERGY SYSTEMS, INC.

for the

U.S. DEPARTMENT OF ENERGY

under Contract DE-AC05-84OR21400 


\section{REPORTS PREVIOUSLY ISSUED IN THIS SERIES}

Previous reports in this series included quarterly and semiannual publications. A complete listing of these reports through March 1990 is given in ORNL-6650.

ORNL-6486 Fossil Energy Program Semiannual Progress Report for October 1987 Through March 1988

ORNL-6522 Fossil Energy Program Semiannual Progress Report for April 1988 Through September 1988

ORNL-6562 Fossil Energy Program Semiannual Progress Report for October 1988 Through March 1989

ORNL-6617 Fossil Energy Program Semiannual Progress Report for April 1989 Through September 1989

ORNL-6634 Fossil Energy Program Semiannual Progress Report for October 1989 Through March 1990

ORNL-6650 Fossil Energy Program Semiannual Progress Report for April 1990 Through September 1990 


\section{CONTENTS}

\section{ABSTRACT}

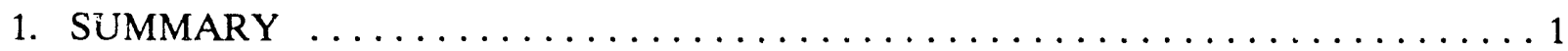

1.1 MATERIALS RESEARCH AND DEVELOPMENT $\ldots \ldots \ldots \ldots \ldots \ldots \ldots 1$

1.2 ENVIRONMENTAL ANALYSIS AND INFORMATION SYSTEMS $\ldots \ldots \ldots \ldots$

1.3 COAL CONVERSION DEVELOPMENT $\ldots \ldots \ldots \ldots \ldots \ldots \ldots \ldots \ldots$

1.4 COAL COMBUSTION RESEARCH $\ldots \ldots \ldots \ldots \ldots \ldots \ldots \ldots \ldots \ldots$

2. MATERIALS RESEARCH AND DEVELOPMENT $\ldots \ldots \ldots \ldots \ldots \ldots \ldots \ldots$

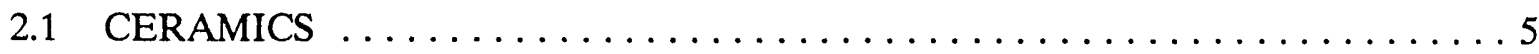

2.1.1 Ceramic Fiber-Ceramic Matrix Hot-Gas Filters $\ldots \ldots \ldots \ldots \ldots \ldots \ldots 6$

2.1.1.1 Background $\ldots \ldots \ldots \ldots \ldots \ldots \ldots \ldots \ldots \ldots \ldots \ldots \ldots \ldots \ldots \ldots \ldots \ldots \ldots$

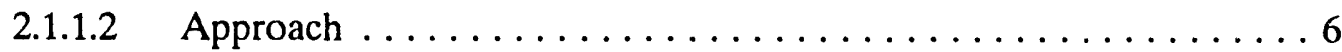

2.1.1.3 Discussion of Current Activities . . . . . . . . . . . . . 7

2.1.2 Effects of Oxidation and Combustion Environments on the Properties of Nicalon $\otimes /$ SiC Composites . . . . . . . . . . . . . . . . . . 9

2.1.2.1 Background $\ldots \ldots \ldots \ldots \ldots \ldots \ldots \ldots \ldots \ldots \ldots$

2.1.2.2 Composite Fabrication $\ldots \ldots \ldots \ldots \ldots \ldots \ldots \ldots \ldots \ldots \ldots$

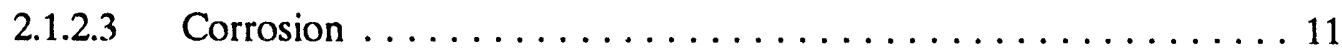

2.1.2.4 Characterization .......................... 12

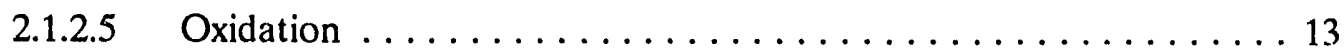

2.1.2.6 Corrosion in Combustion Environments $\ldots \ldots \ldots \ldots \ldots \ldots \ldots$

2.1.2.7 Discussion ............................ 16

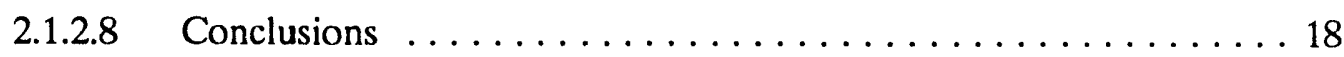

2.1.2.9 References . . . . . . . . . . . . . . . . . . . . . 18

2.1.3 Microwave Sintering of Lanthanum Chromite $\ldots \ldots \ldots \ldots \ldots \ldots \ldots$

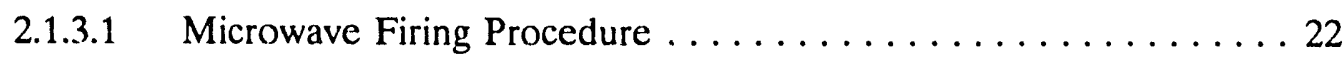

2.1.3.2 Material Selection and Processing ................. 24

2.1.3.3 Temperature Measurement $\ldots \ldots \ldots \ldots \ldots \ldots \ldots \ldots \ldots 24$

2.1.3.4 Sintering of $\mathrm{LaCrO}_{3}$ Materials $\ldots \ldots \ldots \ldots \ldots \ldots \ldots \ldots \ldots$

2.1.3.5 References .......................... 30 
2.2 ALLOY DEVELOPMENT $\ldots \ldots \ldots \ldots \ldots \ldots \ldots \ldots \ldots \ldots \ldots \ldots \ldots \ldots \ldots \ldots \ldots \ldots \ldots$

2.2 .1 Environmuntal Effects on Iron Aluminides $\ldots \ldots \ldots \ldots \ldots \ldots \ldots \ldots \ldots \ldots$

2.2.1.1 Microscopic Studies of Reaction Product Scales . . . . . . . 32

2.2.1.2 Exposures to Mixed Gases $\ldots \ldots \ldots \ldots \ldots \ldots \ldots \ldots \ldots \ldots$

2.2.1.3 Tests in Operating Gasifiers . ................. 37

2.2.1.4 References ............................. 39

2.2.2 Investigation of Austenitic Alloys for Advanced Heat Recovery and Hot-Gas Cleanup Systems . .............................. 39

2.2.2.1 Long-Time Testing of Lean Stainless Steels $\ldots \ldots \ldots \ldots \ldots 40$

2.2.2.2 Testing of Weldments . . . . . . . . . . . . . . . 41

2.2.2.3 Evaluation of Modified Alloy $800 \mathrm{H} \ldots \ldots \ldots \ldots \ldots \ldots .43$

2.2.2.4 Alloys for Hot-Gas Cleanup Applications . .............. 44

2.2.2.5 References ........................... 49

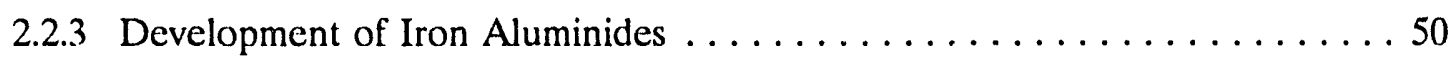

2.2.3.1 References ............................. 60

2.3 CORROSION AND EROSION RESEARCH $\ldots \ldots \ldots \ldots \ldots \ldots \ldots \ldots$

2.3.1 The Measurement of the Mechanical Properties of Oxide Scales .......6 60 2.3.1.1 References ......................... 71

2.3.2 Erosion Studies on a $\mathrm{Fe}_{3} \mathrm{Al}$-Based Iron Aluminide and $1100 \mathrm{Al} \ldots \ldots .72$ 2.3.2.1 References .......................... 83

2.4 TECHNOLOGY ASSESSMENT AND TECHNOLOGY TRANSFER $\ldots \ldots \ldots 84$

2.4.1 Coal Conversion and Utilization Plant Support Services ............ 84

3. ENVIRONMENTAL ANALYSIS AND INFORMATION SYSTEMS $\ldots \ldots \ldots \ldots 93$

3.1 ENVIRONMENTAL SUPPORT TO THE CLEAN COAL PROGRAM .....993

4. COAL CONVERSION DEVELOPMENT $\ldots \ldots \ldots \ldots \ldots \ldots \ldots \ldots \ldots \ldots$

4.1 BIOLOGICAL COAL CONVERSION $\ldots \ldots \ldots \ldots \ldots \ldots \ldots \ldots \ldots . \ldots 9$

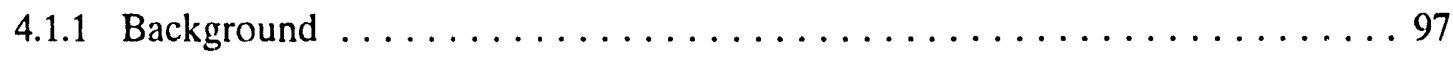

4.1.1.1 Anaerobic Microbial Coal Conversion .............. 97

4.1.1.2 Anaerobic Enzymatic Solubilization of Coal . .......... 98

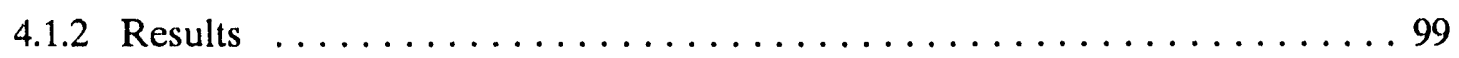

4.1.2.1 Anaerobic Microbial Coal Conversion .............. 99 
4.1.2.1.1 Culture Enrichment . . . . . . . . . . . . .99

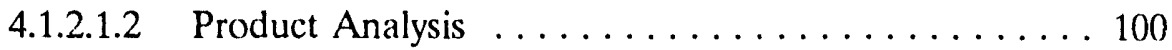

4.1.2.2 Enzymatic Solubilization of Coal . . . . . . . . . . . . . . 102

4.1.2.2.1 Chemical Modification of Enzymes ......... 102

4.1.2.2.2 Benzene Solubilization of Membrane-Bound Hydrogenase . . . . . . . . . . . . 103

4.1.2.2.3 Degradation of a Model Compound . . . . . . . . . 104

4.1.2.2.4 Coal Solubilization Tests . . . . . . . . . . . . 104

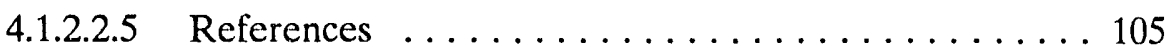

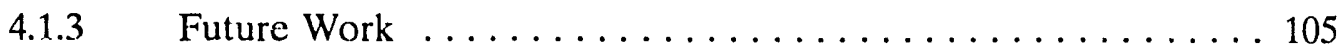

4.1.3.1 Anaerobic Microbial Coal Conversion . . . . . . . . . . . . 105

4.1.3.2 Enzymatic Solubilization of Coal . . . . . . . . . . . 105

4.2 MILD GASIFICATION PRODUCT CHARACTERIZATION . . . . . . 105

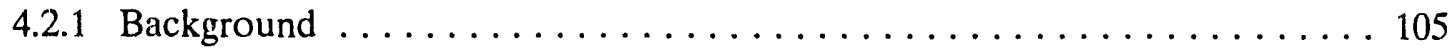

4.2.2 Progress for This Reporting Period . . . . . . . . . . . . . . 107

5. COAL COMBUSTION RESEARCH ......................... 109

5.1 TECHNICAL SUPPORT TO PETC-USAID COLLABORATIVE COAL PROJECTS ... . . . . . . . . . . . . . . . . . . . . . . . 109

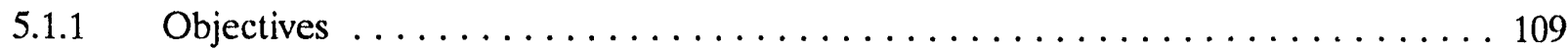

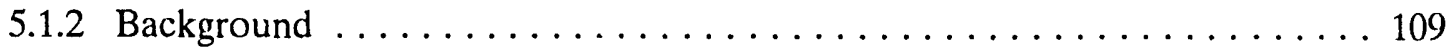

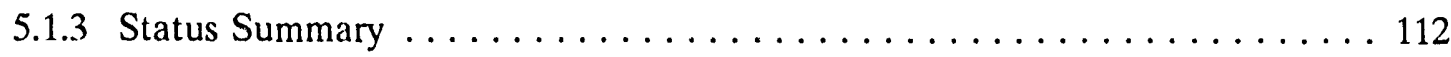

6. FOSSIL FUELS SUPPLIES MODELING AND RESEARCH . . . . . . . . . . 119

6.1 STRATEGIC PETROLEUM RESERVE PLANNING AND MODELING . . . 119

6.1.1 Benefits of Alternative Drawdown and Distribution Capabilities for the

Strategic Petroleum Reserve . . . . . . . . . . . . . . . . . . 119

6.1.2 Estimating the Benefits and Costs of a Refined Petroleum Product Reserve 119

7. EVALUATIONS AND ASSESSMENTS $\ldots \ldots \ldots \ldots \ldots \ldots \ldots \ldots \ldots \ldots \ldots \ldots$

7.1 THE EXTERNAL COSTS OF FUEL CYCLES PROJECT . . . . . . . . . . 121

7.1.1 Summary of Meetings and Documents Related to the External Costs of Fuel Cycles Project, June 1991 . . . . . . . . . . . . . . . . . . . . . . . . . 124

7.1.1.1 Significant Meetings . . . . . . . . . . . . . . . . . 124 
7.1.1.2 Documents Prepared by ORNL and RFF . . . . . . . . 125

7.1.1.3 Documents Prepared by the CEC . . . . . . . . . . . . 125

7.2 ANALYTICAL ASSISTANCE AND ANALYSIS FOR THE STRATEGIC PETROLEUM RESERVE .................... 126

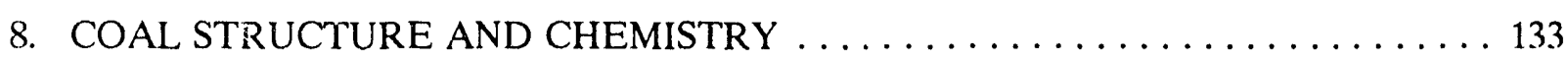

8.1 CHEMISTRY AND STRUCTURE OF COALS: METHODOLOGY FOR ASSESSING SURFACE AREA AND POROSITY FOR CARBONACEOUS MATERIALS UTILIZING INERT VAPOR SORPTION ISOTHERM . . . . 133

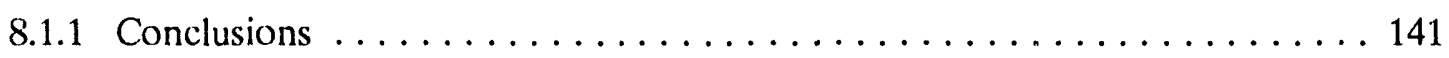

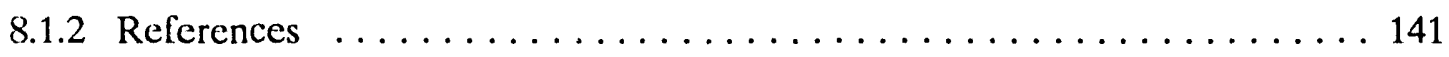

8.2 INVESTIGATION OF COAL SURFACES AND INTERFACES $\ldots \ldots \ldots \ldots 14$

8.2.1 Analytical Characterization of Coal Surfaces and Interfaces . . . . . . . . 142

8.2 .2 References . . . . . . . . . . . . . . . . . 144

APPENDIX. ORGANIZATION CHART FOR THE FOSSIL ENERGY PROGRAM . . 149 


\title{
FOSSIL ENERGY PROGRAM SEMIANNUAL PROGRESS REPORT FOR OCTOBER 1990 THROUGH MARCH 1991
}

\author{
R. R. Judkins, Program Manager
}

\begin{abstract}
This report covers progress made during the period October 1, 1990, through March 31, 1991, for research and development projects that contribute to the advancement of various fossil energy technologies. Projects on the Fossil Energy Program are supported by the DOE Office of Fossil Energy, the DOE Morgantown Energy Technology Center, the DOE Pittsburgh Energy Technology Center, the DOE Fossil Energy Clean Coal Technology Program, the DOE Office of Basic Energy Sciences, the DOE Fossil Energy Office of Petroleum Reserves, the DOE Fossil Energy Naval Petroleum and Oil Shale Reserves, and the U.S. Agency for International Development. The Fossil Energy Program organization chart is shown in the appendix.
\end{abstract}

\section{SUMMARY}

\subsection{MATERIALS RESEARCH AND DEVELOPMENT}

The materials research and development for fossil energy applications at Oak Ridge National Laboratory consists of: ceramics development for high temperature applications, new metal alloys with unique mechanical properties, and corrosion and erosion research to understand the material behavior in combustion and conversion environments. The transfer of technology funded under this program is enhanced with concerted efforts to interact with industry, perform joint programs and work with those interested in using the technology.

Emphasis this period was on: the behavior of $\mathrm{SiC}$ and coatings on Nicalon $\otimes / \mathrm{SiC}$ composites in simulated fossil fuel environments, ceramic membranes for hydrogen separation, microwave sintering of lanthanum chromite for fuel cells and continuing alloy development of iron aluminides including weldability, environmental effects and fracture behavior. Austenitic alloys were pursued for advanced heat recovery and hot gas cleanup, and fundamental studies on erosion/corrosion continued. Our materials technical support to the Wilsonville (Alabama) 
Advanced Coal Liquefaction Facility, the Great Plains Coal Gasification Plant and selected Clean Coal Technology Program Projects has shown increased activity.

$\mathrm{SiC}$ has progressed to be a viable candidate for fossil systems applications, but it is susceptible to attack by combustion gases above $1200^{\circ} \mathrm{C}$. To understand the nature of the attack, Nicalon $\otimes / S i C$ composites have been exposed to oxidizing and simulated fossil fuel environments to evaluate corrosion, glass layer formation, flexure strength degradation, and compositional changes at the surface and fiber interface. Coatings are being developed to protect $\mathrm{SiC}$ from corrosion. Several candidates for oxide coatings on $\mathrm{SiC}$ have been identified and systems to apply the coatings are being developed

A process of producing ceramic membranes to separate hydrogen from gasified coal at high temperatures has produced membranes with a mean pore radius of 7 angstroms or less.

With fuel cells, lanthanum chromite is often the design material that acts as the electrical interconnect between the stacks of electrolytic cells. A composition of lanthanum chromite was microwave sintered and annealed and the special microwave effect did not occur with this material as it did with alumina and zirconia.

The evaluation of commercial and developmental austenitic alloys for advanced heat recovery and hot-gas cleanup systems is being completed. Long-time creep testing $(45,000 \mathrm{~h})$ of the lean stainless steels showed an extrapolated $100,000 \mathrm{~h}$, high average rupture strength of $100 \mathrm{MPa}$ and $5 \%$ rupture strain at $700^{\circ} \mathrm{C}$. Testing of weldments was extended beyond $10,000 \mathrm{~h}$ and $20 \mathrm{Cr}-3 \mathrm{GNi}-2 \mathrm{Mo}-\mathrm{Fe}$ alloys reached $30,000 \mathrm{~h}$. Research has been initiated to examine alloys at $850^{\circ} \mathrm{C}$ for hot-gas cleanup.

Research on $\mathrm{Fe}_{3} \mathrm{Al}$ alloys has shown that specific compositions coupled with thermomechanical processing techniques can produce room temperature ductilities of $10-20 \%$ and yield strengths of $500 \mathrm{MPa}$ up to $600^{\circ} \mathrm{C}$. The creep resistance can also be increased with small additions of $\mathrm{Mo}, \mathrm{Nb}$, and $\mathrm{Zr}$. Selected alloys have been vacuum induction melted and hot worked at ORNL and two industrial concerns. The tensile and creep properties were similar to previous laboratory heats. Weldability is a function of the alloy composition and processing conditions. Several compositions were found to be weldable using appropriate preheat and postweld heat treatments to avoid hydrogen embrittlement. Charpy V-notch testing of one composition indicated a high ductile-to-brittle transition temperature. Grain size and annealing temperature greatly affected the toughness behavior. Several iron aluminide compositions are being evaluated in atmospheres typical of coal gasifiers involving 
gas mixtures of $\mathrm{H}_{2} \mathrm{~S}-\mathrm{H}_{2}-\mathrm{H}_{2} \mathrm{O}$ at 700 to $800^{\circ} \mathrm{C}$. The protective scales formed in sulfurcontaining environments are being examined and compared to those formed in air. Oxide growth processes are being monitored using ${ }^{18} \mathrm{O} . \mathrm{Fe}_{3} \mathrm{Al}$ was eroded in single particle and multiple particle tests to determine deformation behavior and thermal effects. The overall erosion resistance of the alloy was relatively good and may be improved as the alloy's ductility is improved.

The mechanical properties of oxide scales affect the ability of high temperature materials to resist degradation by oxidation and corrosion. Recently a mechanical properties microprobe has been made available to measure the hardness, Young's modulus, and plasticity of scales and bulk oxides by depth sensing submicron indentation testing. The results obtained on iron aluminide and chromium were consistent with those expected based on other properties of these materials.

\subsection{ENVIRONMENTAL ANALYSIS AND INFORMATION SYSTEMS}

Activities in environmental analysis and information systems included assistance to the DOE Office of Clean Coal Technology by preparing four issue papers discussing environmental topics related to the Clean Coal Program, especially the effects of commercial deployment of clean coal technologies on those topic areas. Topics selected for the papers were acid deposition, the Clean Air Act Amendments of 1990, global climate change, and solid waste.

ORNL is also providing assistance to the Morgantown and Pittsburgh Energy Technology Centers (METC and PETC) in reviewing and preparing documents required by the National Environmental Policy Act (NEPA) for several projects selected for the Clean Coal Program. A key activity was the preparation for PETC of a preliminary draft Environmental Impact Statement (EIS) for the Healy Clean Coal Project in Healy, Alaska. This work is notable because it is the first site-specific EIS prepared for the Clean Coal Program.

\subsection{COAL CONVERSION DEVELOPMENT}

Coal conversion research has continued on the biological solubilization of coal and the characterization of mild gasification product. 


\subsection{COAL COMBUSTION RESEARCH}

In response to the request from the Pittsburgh Energy Technical Center (PETC), the Oak Ridge National Laboratory (ORNL) is providing technical assistance in the implementation of collaborative coal projects under the U.S. Agency for International Development (USAID)/Government of India (GOI) Phase II, Alternataive Energy Resources Development (AERD) Project. 


\title{
2. MATERIALS RESEARCH AND DEVELOPMENT
}

\author{
R. R. Judkins
}

This section describes research and development activities performed for the Fossil Energy Materials Program. Work on the Fossil Energy Materials Program includes the fabrication and characterization of fiber-reinforced ceramic composites, development of ceramic fiber-ceramic matrix hot-gas filters, development and testing of ceramic membranes for separation of gases, microwave sintering of materials for fuel cells, development of iron aluı..inides, studies of environmental effects on iron aluminides, development and evaluation of advanced austenitic alloys, evaluation of materials for hot-gas filter support systems, fundamental studies of erosion and corrosion, development of surface treatments and alloy modifications for corrosion-resistant oxide scales, and materials testing and failure analysis support to coal conversion and utilization plants.

\subsection{CERAMICS}

Ceramics are of interest in fossil energy systems, particularly for use in heat engines and heat recovery devices, because of their ability to withstand high temperatures and corrosive-erosive environments. Most anticipated fossil energy applications of this type of material involve temperatures above $1100^{\circ} \mathrm{C}$. Stationary heat engines for the production of power are an important application for coal and coal-derived fuels and represent significant materials problems that are not always encountered in engines that use petroleum fuels or natural gas. Gas turbine and diesel engines are the primary engine types for use in fossil systems. The application of ceramics for heat recovery devices if of interest because of high temperatures and hostile environments that make available alloys unsuitable because of their lack of the mechanical strength or corrosion resistance required.

Potential applications for ceramic heat exchangers in fossil energy systems are in two areas. In one, the heat exchanger is used to transfer heat from a fossil-fuel-firing process to a high-pressure working fluid. The second application uses the heat exchanger (recuperator) to recover heats from hot waste gases by preheating combustion are, preheating batch materials, preheating process reactants, or for some similar purpose. 
2.1.1 Ceramic Fiber-Ceramic Matrix Hot-Gas Filters - D. P. Stinton, J. C. McLaughlin, and L. R. Riester

The purpose of this project is to develop a ceramic fiber-ceramic matrix composite that will be suitable as a high-temperature particulate filter for use in hot-gas cleanup systems. The goal is to produce a composite that has the requisite strength, toughness, and corrosion resistance, but which also has sufficient porosity to be permeable to the gas stream and the size and distribution of porosity to be an effective filter. A practical process will be developed for fabricating porous ceramic fiber-ceramic matrix filter materials.

\subsubsection{Background}

The AR\&TD Fossil Energy Materials Program has been developing composite materials with improved properties for use in fossil energv systems. One of the materials is a ceramic fiber-ceramic matrix composite made by chemical vapor deposition. In this process, a ceramic material $(\mathrm{SiC})$ is deposited on the fibers of a fibrous preform bonding them together, and partialiy filling the space between the fibers. This process was developed to produce ceramic fiber filter materials for use in hot-gas cleanup systems. Fibrous preforms containing appropriate volume loading were partially infiltrated with a ceramic matrix to provide sufficient strength, toughness, and porosity to provide adequate gas fiow through the porous fiber medium. Such a composite provides excellent filter efficiency and cleanability and should have the mechanical properties required to tolerate the cyclic stresses imposed in service. Because of interest expressed by industry, the AR\&TD Fossil Energy Materials Program subcontracted with the $3 \mathrm{M}$ Company to fabricate full-size fiber-reinforced candle filters for proof testing.

\subsubsection{Appruach}

$\mathrm{SiC}$ is currently the prime candidate for the matrix of ceramic fiber-ceramic matrix hot gas filters because of its high strength at elevated temperature, excellent oxidation resistance, good thermal shock resistance, and light weight. Unfortunately, sodium, potassium, and steam have been shown to cause degradation of $\mathrm{SiC}$ at temperatures above $\approx 1000^{\circ} \mathrm{C}$. The outer surfaces of $\mathrm{SiC}$ components oxidize at high temperatures to form a silica layer that inhibits further oxidation. However, sodium from the environment or impurities present in the fuel can react with this silica layer, such that it is no longer protective. The primary corrosion mechanism is the formation of a sodium-silicate glass at temperatures above $\approx 800^{\circ} \mathrm{C}$. The objective of this research is to develop a coating that will protect the SiC filters from sodium corrosion as well as provide oxidation protection. 


\subsubsection{Discussion of Current Activities}

Development of a protective coating for $\mathrm{SiC}$ is difficult because the coatings crack due to the mismatch in coeff:cient of thermal expansion (CTE) between the substrate (low CTE) and the coating (high CTE). The list of potential materials for corrosion protection of $\mathrm{SiC}$ is very limited because the material must be an oxide (for oxidation resistance) with a CTE approximately equal to $\mathrm{SiC}\left(5.5 \times 10^{-6} /{ }^{\circ} \mathrm{C}\right)$. Carbon/carbon composites are a material with a very low thermal expsansion $(\approx 0)$ that must be protected from oxidation in high-temperature aerospace applications. However, after 20 years of investigation no oxidation resistant coatings have been found that can survive the dramatic thermal cycles, although several materials with low CTE's were identified that might be useful for the higher CTE SiC-matrix filters.

(Table 2.1-1).

Development of processes to chemically vapor deposit all of the potential materials describeci above would be very costly and time consuming. Therefore, relatively easy to prepaze hot-pressed samples of these materials are being exposed to sodium-containing combustion environments to assess their corrosion resistance. Chemical vapor deposition processes will then be developed for the most promising materials.

Table 2.1-1. Refractory oxides with potential for oxidation/corrosion protection

\begin{tabular}{lll}
\hline Compound & $\begin{array}{l}\text { Density } \\
\left(\mathrm{g} / \mathrm{cm}^{3}\right)\end{array}$ & $\begin{array}{c}\mathrm{CTE} \\
\left(\mathrm{x} 10^{-6} / \cdot \mathrm{C}\right)\end{array}$ \\
\hline & & \\
$\mathrm{A}_{2} \mathrm{O}_{3}{ }^{*}$ & 3.97 & 8.0 \\
$3 \mathrm{~A}_{2} \mathrm{O}_{3} \cdot 2 \mathrm{SiO}_{2}$ & 2.8 & 5.7 \\
$\mathrm{SiC}^{*}$ & 3.21 & 5.5 \\
$\mathrm{ZrTiO}_{4}$ & $\approx 5$ & $\approx 4$ \\
$\mathrm{HFTiO}_{4}$ & $\approx 5$ & $\approx 4$ \\
$\mathrm{Ta}_{2} \mathrm{O}_{5} \cdot 6 \mathrm{ZrO}_{2}$ & $\approx 6$ & $\approx 4$ \\
$\mathrm{Ta}_{2} \mathrm{O}_{5} \cdot 6 \mathrm{HfO}_{2}$ & $\approx 6$ & $\approx 4$ \\
$\mathrm{Ta}_{2} \mathrm{O}_{5}$ & 8.02 & 3.6 \\
$\mathrm{Si}_{3} \mathrm{~N}_{4}{ }^{*}$ & 3.19 & 3.0 \\
$\mathrm{~A}_{2}{ }^{2} \mathrm{TiO}$ & 3.68 & 2.2 \\
carbon/carbon $^{*}$ & 1.9 & $\approx 0$ \\
\end{tabular}

${ }^{*}$ Included only as a reference and not as a potential coating. 
Processes for the chemical vapor deposition of $\mathrm{Ta}_{2} \mathrm{O}_{5}$ have already been developed at this laboratory. The system consists of an inductively heated substrate within a quartz tube sealed on each end by threaded stainless steel end caps. Chlorine and argon gas are introduced into a tantalum chlorinator electrically heated to $600^{\circ} \mathrm{C}$. $\mathrm{TaCl}_{5}$ exiting the chlorinator is mixed with oxygen flowing through a separate inlet tube. The deposition temperature $\left(1000-1300^{\circ} \mathrm{C}\right)$ is measured by an optical pyrometer sighting through a window in the end cap directly on the substrate.

Specimens of $\mathrm{Al}_{2} \mathrm{TiO}_{5}, \mathrm{ZrTiO}_{4}$, and $3 \mathrm{Al}_{2} \mathrm{O}_{3} \cdot 2 \mathrm{SiO}_{2}$ were successfully hot pressed for corrosion testing. Evaluation of these materials by $\mathrm{X}$-ray diffraction revealed that the desired crystalline compounds had been produced. The initial hot-pressing conditions selected for the $\mathrm{Al}_{2} \mathrm{TiO}_{5}$ produced a porous pellet, therefore, a dense specimen was obtained from a commercial source. X-ray diffraction of the commercial material showed that the outer surface was predominantly $\mathrm{Al}_{2} \mathrm{O}_{3}$, whereas the interior of the pellet was $\mathrm{Al}_{2} \mathrm{TiO}_{5}$. Tise hotpressed pellets of $\mathrm{ZrTiO}_{4}$ and $3 \mathrm{Al}_{2} \mathrm{O}_{3} \cdot 2 \mathrm{SiO}_{2}$ were fine grained, but the former contained approximately $20 \%$ porosity.

After exposing each of the candidate materials plus a sintered $\alpha$-SiC specimen to a combustion environment at $1000^{\circ} \mathrm{C}$, the pellets were examined metallographically. The $\alpha$-SiC had a surface layer of glass about $20 \mu \mathrm{m}$ thick. Significantly better corrosion resistance, which is consistent with published results of Federer, was exhibited by $3 \mathrm{Al}_{2} \mathrm{O}_{3} \cdot 2 \mathrm{SiO}_{2}$ which had a $10 \mu \mathrm{m}$ glass layer. Further improvements in corrosion resistance are seen by $\mathrm{ZrTiO}_{4}$ and $\mathrm{Al}_{2} \mathrm{TiO}_{5}$ since the reaction layers were $\approx 4 \mu \mathrm{m}$ and $<2 \mu \mathrm{m}$ thick, respectively. $\mathrm{Al}_{2} \mathrm{O}_{3}$ grains were observed on the surface of the polished $\mathrm{Al}_{2} \mathrm{TiO}_{5}$ sample, thus verifying the $\mathrm{X}$-ray diffraction results discussed previously.

SiC-coated graphite substrates overcoated with $\mathrm{Ta}_{2} \mathrm{O}_{5}$ were also corrosion tested. During coating in an oxidizing environment, the $\mathrm{SiC}$ formed a relatively thick crystalline $\mathrm{SiO}_{2}$ protective layer. The $\mathrm{Ta}_{2} \mathrm{O}_{5}$ coating nucleated onto the $\mathrm{SiO}_{2}$ with small equiaxed grains that grew into large columnar ones normal to the surface. Corrosion testing left the $\mathrm{Ta}_{2} \mathrm{O}_{5}$ coating and the crystalline sublayer unaffected.

Successful hot-pressing conditions have not yet been determined for $\mathrm{HfTiO}_{4}$, $\mathrm{Ta}_{2} \mathrm{O}_{5} \bullet 6 \mathrm{ZrO}_{2}$, and $\mathrm{Ta}_{2} \mathrm{O}_{5} \bullet 6 \mathrm{HfO}_{2}$. Analysis of the pellets produced to date by X-ray diffraction have indicated unidentified phases. Additional process development will be required before corrosion testing can be initiated for these materials. 


\subsubsection{Effects of Oxidation and Combustion Environments on the Properties of Nicalon ${ }^{\star} / \mathrm{SiC}$ Composites - R. A. Lowden and R. D. James}

The stability of Nicalon ${ }^{\otimes} / \mathrm{SiC}$ composites with a graphitic carbon interface layer at elevated temperatures in oxidizing and simulated fossil fuel environments has been investigated. Composite specimens with and without an external $\mathrm{SiC}$ surface coating have been oxidized in air and have been exposed to a variety of combustion environments at a temperature of $1273 \mathrm{~K}$. A burner rig furnace was constructed for simulating corrosive fossil fuel environments containing water vapor, sulfur, and sodium. Post-exposure room temperature flexure tests were performed to measure the strengths of the samples, and optical and electron microscopy have been employed to analyze corrosion, glass layer formation, and compositional changes at the surface of the specimens and at the fiber-matrix interface. Correlations between exposure environment, the interface, and mechanical properties of the composites were examined.

\subsubsection{Background}

The efficiency of many energy conversion and industrial processes can be improved by simply increasing operating temperatures and pressures. The increased severity of the environments, however, requires materials with exceptional high temperature properties and corrosion resistance. Ceramics exhibit excellent high temperature strength and stability, and thus are leading candidates for use in the critical components of high-temperature combustion and power generation systems. However, the utilization of conventional ceramics in these high-temperature, high-stress applications is hindered by their inherent brittleness and lack of damage tolerance.

One method of improving the fracture properties of a ceramic is the addition of fibers. The incorporation of high-strength fibers to brittle glass and ceramic matrices has produced substantial increases in strength, crack resistance, and work of fracture in many of these materials. ${ }^{1-3}$ Fiber-reinforced ceramic composites are currently being evaluated for an assortment of high temperature applications. ${ }^{4,5}$ The commercial availability of a variety continuous ceramic fibers coupled with recent advances in the processing of ceramic matrices has resulted in significant activity in the development, characterization, and utilization of continuous fiber-reinforced ceramic composites.

To date, emphasis in the development of these advanced materiais has been placed on processing and mechanical properties. Glass-ceramic and ceramic matrices are being 
reinforced with polymer-derived $\mathrm{Si}-\mathrm{C}-\mathrm{O}$ fibers and moderate quantities of these materials are being fabricated using a variety of techniques. ${ }^{1-6}$ Although exceptional room and elevated temperature properties have been reported, only limited information has been presented regarding the stability of these composite systems in simulated service environments. Oxidation and corrosion will have detrimental effects on the fibers and matrices and thus the properties of the composites. These issues must be addressed before final acceptance of these materials for critical components in elevated-temperature commercial applications.

It is also well known that although the fibers and matrix play major roles in determining the final properties of a composite, the fiber-matrix interface has a significant influence on the fracture behavior and mechanical properties of reinforced ceramics. ${ }^{7-9}$ Typically, fiber coatings are used to protect ceramic fibers from chemical attack during processing and to control interfacial forces. ${ }^{8,9}$ Carbon, whether intentionally deposited on the fibers prior to consolidation ${ }^{8,9}$ or formed serendipitously during processing, ${ }^{10}$ is the most commonly used interlayer in ceramic composites today. Carbon coatings have performed well in a variety of systems, however, the poor oxidation resistance of carbonaceous materials has prompted intense scrutiny of their usefulness at elevated temperatures in oxidizing environments. Thus the present investigation examined the effects of elevated temperature exposure to corrosive environments on the interface and properties of Nicalon $\% \mathrm{SiC}$ composites with a graphitic carbon interface layer.

\subsubsection{Composite Fabrication}

Fibrous preforms were fabricated by stacking multiple layers of Nicalon ${ }^{\circledR}$ plain-weave fabric rotated in a $0 \pm 30^{\circ}$ sequence within the cavity of a graphite holder. The layers were hand compressed to produce a preform with a nominal loading of $40 \mathrm{vol} \%$ fiber and were held in place by a perforated graphite lid pinned to the holder. The cloth sizing was removed through multiple washings with acetone. The nominal size of the fibrous preforms was $75 \mathrm{~mm}$ in diameter and $16 \mathrm{~mm}$ thick.

Preforms were next precoated with a $0.3 \mu \mathrm{m}$ layer of carbon, deposited from an argon/propylene mixture at $1375 \mathrm{~K}$ and $3.3 \mathrm{kPa}$ pressure. The thickness of the carbon layer was determined from weight gain and polarized light microscopy of polished cross sections. The preforms were densified with $\mathrm{SiC}$ using a forced-flow thermal-gradient chemical vapor infiltration (FCVI) technique which has been previously described in detail elsewhere. ${ }^{6,8,9,11}$ The $\mathrm{SiC}$ matrix was produced by the decomposition of methyltrichlorosilane $\left(\mathrm{CH}_{3} \mathrm{SiCl}_{3}\right.$ or 
MTS) in hydrogen using a hot-surface temperature of $1473 \mathrm{~K}$ and atmospheric pressure. Processing times were $\approx 40 \mathrm{~h}$ and the infiltrated composite samples had a nominal density of $2.6 \mathrm{~g} / \mathrm{cm}^{3}$, approximately $85-90 \%$ of theoretical density.

Bars were cut from the samples parallel to the $0^{\circ}$ orientation of the top layer of cloth using a diamond saw, and tensile and compression surfaces were ground parallel to the long axis of the specimen. The average dimensions of the test bars from the composite samples were $3 \times 4 \times 50 \mathrm{~mm}$ and all specimens were measured and weighed to determine densities. A portion of the flexure specimens were coated with a $40 \mu \mathrm{m} \mathrm{SiC} \mathrm{layer} \mathrm{deposited} \mathrm{from} \mathrm{MTS} \mathrm{in}$ hydrogen at $1473 \mathrm{~K}$ and $3.3 \mathrm{kPa}$. The thickness of the $\mathrm{SiC}$ coating was calculated from weight gain and surface area measurements.

\subsubsection{Corrosion}

Composite specimens were oxidized in static air at $1273 \mathrm{~K}$ for 100,500 , and $1000 \mathrm{~h}$. Flexure bars with and without $\mathrm{SiC}$ surface coatings were placed in the cavity of an atmospheric box furnace and heated to temperature at a rate of $300^{\circ} / \mathrm{h}$. Once the furnace achieved equilibrium, the final temperature was measured and set using a hand-held optical pyrometer, and maintained using a thermocouple-controlled programmer. At the specified time, the furnace was shut off and allowed to cool unassisted.

A burner rig furnace, shown in Fig. 2.1-1, was employed to examine the oxidation and corrosion of the Nicalon ${ }^{\otimes} / \mathrm{SiC}$ composite specimens in simulated combustion environments. ${ }^{12-14}$ Constant temperature was maintained by a resistively-heated clam shell furnace, and an aluminum oxide tube was used as a combustion chamber. Concentric aluminum oxide tubes carried natural gas, air, and other gases into the hot zone where they mixed and burned. A platinum wire mesh affixed to the outlet of the burner tube ensured ignition of the gases. Mass flow controllers were used to regulate gas flow and total gas flow was maintained at a nominal $5.5 \mathrm{l} / \mathrm{min}$ in all experiments.

Flexure bars were arranged laterally on an aluminum oxide base placed approximately $25 \mathrm{~cm}$ from the burner outlet. The furnace was heated to $1273 \mathrm{~K}$ and allowed to equilibrate. Combustion gases were then introduced to the system and conditions were held constant for $100 \mathrm{~h}$ upon which the reactant flows were terminated and the furnace allowed to cool. Building supplied air and natural gas were used and a fuel to air ratio of 0.1 was maintained in all tests. The calculated composition of the combustion atmosphere in the burner rig furnace are given in Table 2.1-2. 


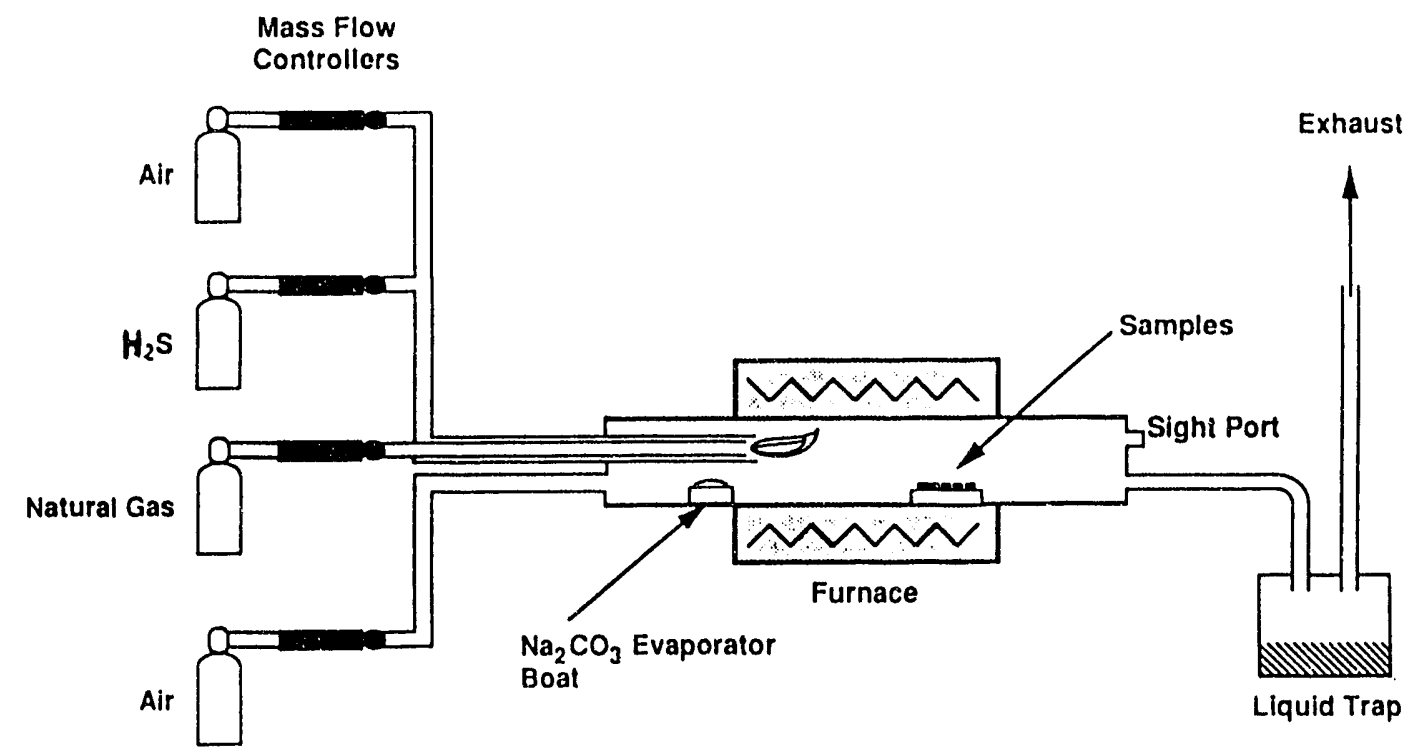

Fig. 2.1-1. Schematic of the burner rig furnace.

Sulfur containing atmospheres, which can result from the burning of fuels such as coal, were simulated by adding hydrogen sulfide gas, $\mathrm{H}_{2} \mathrm{~S}$, to the combustion gas mixture. A sulfur content of $1 \%$ was selected from various sources ${ }^{15-17}$ and was accomplished by adding 50 $\mathrm{cm}^{3} / \mathrm{min} \mathrm{H}_{2} \mathrm{~S}$ to the gas/air mixture. It was predicted that the addition of sulfur would result in the production of $\mathrm{H}_{2} \mathrm{SO}_{3}$ in the combustion gas. The effects of the addition of the sulfurcontaining gas on the combustion products of natural gas and air are displayed in Table 2.1-2

Sodium carbonate, $\mathrm{Na}_{2} \mathrm{CO}_{3}$, was used as the source of sodium in the experiments. ${ }^{17-19}$ An aluminum oxide boat was filled with $\mathrm{Na}_{2} \mathrm{CO}_{3}$ and sintered at $1173 \mathrm{~K}$ for $24 \mathrm{~h}$. The sintered sample was placed in the burner rig furnace upstream from the composite specimens and heated to $1173 \mathrm{~K}$. $\mathrm{Na}_{2} \mathrm{CO}_{3}$ vapor was carried to the samples by passing a portion of the combustion air over the boat. $\mathrm{A} \mathrm{Na}_{2} \mathrm{CO}_{3}$ flow of $\approx 0.25 \mathrm{~cm}^{3} / \mathrm{min}$ was calculated from the weight change of the sintered sample, producing $\approx 80 \mathrm{ppm} \mathrm{Na}$ in the gas mixture (Table 2.12).

\subsubsection{Characterization}

Room temperature flexure strengths for the treated composites were measured in fourpoint bending. A support span of $40 \mathrm{~mm}$, a loading span of $20 \mathrm{~mm}$, and a crosshead speed of $0.508 \mathrm{~mm} / \mathrm{min}$ were used and all specimens were loaded perpendicular to the layers of cloth. 
Table 2.1-2. Calculated composition of combustion atmospheres

\begin{tabular}{lccc}
\hline \multicolumn{4}{c}{ Combustion product gases } \\
$\mathrm{Gas}+\mathrm{Air}$ & $+1 \% \mathrm{H}_{2} \mathrm{~S}+\mathrm{Na}_{2} \mathrm{CO}_{3}$ & Species & (vol\%) \\
\hline $\mathrm{N}_{2} 7$ & 71.2 & 70.9 & 71.2 \\
$\mathrm{H}_{2} \mathrm{O} 1$ & 15.7 & 14.7 & 15.7 \\
$\mathrm{CO}_{2}$ & 9.3 & 9.3 & 9.3 \\
$\mathrm{O}_{2}$ & 1.9 & 1.4 & 1.9 \\
$\mathrm{NO}_{x}$ & 1.8 & 2.5 & 1.8 \\
$\mathrm{H}_{2} \mathrm{SOa}$ & - & 1.0 & $-\overline{\mathrm{Nam} \mathrm{Na}}$ \\
$\mathrm{Na}_{2} \mathrm{O}$ & - & - & $\sim 80 \mathrm{ppm}$ \\
\hline
\end{tabular}

Load-displacement curves were recorded to examine the fracture process and determine the loads for ultimate strength calculations.

The fracture surfaces of the specimens were examined using a scanning electron microscope (SEM). Specimens that did not completely part during flexure testing were broken by hand so that the fracture surfaces could be examined. Polished specimen cross sections were prepared using standard metallographic techniques and were examined using optical microscopy. Detailed characterization of the interfacial regions of the composites was also performed employing transmission electron microscopy (TEM).

\subsubsection{Oxidation}

Although the exposure to $1273 \mathrm{~K}$ in air produced a slight discoloration of the composite specimens with a $\mathrm{SiC}$ surface coating, suggesting some degree of oxidation, the strengths of the specimens were unaffected. SiC-coated samples maintained strengths in excess of $300 \mathrm{MPa}$ even after $1000 \mathrm{~h}$ (Fig. 2.1-2). In contrast, all unprotected specimens exhibited a significant loss in flexure strength even after short treatment times. The detrimental effects of oxidation on the fracture behavior, i.e., fiber pull-out and toughness, of the unprotected specimens were found to be progressive (Fig. 2.1-3). Short term oxidation at $1273 \mathrm{~K}$ resulted in a loss of strength, however, the composites demonstrated gradual failure accompanied by extensive fiber pull-out. As the length of exposure was increased, the degree of fiber pull-out diminished, eventually resulting in completely brittle fracture. TEM analysis of the embrittled composites revealed that an amorphous silica layer replaced the carbon coating at the fiber-matrix interface throughout the specimens (Fig. 2.1-4). 
ORNL-DWG 90-9705

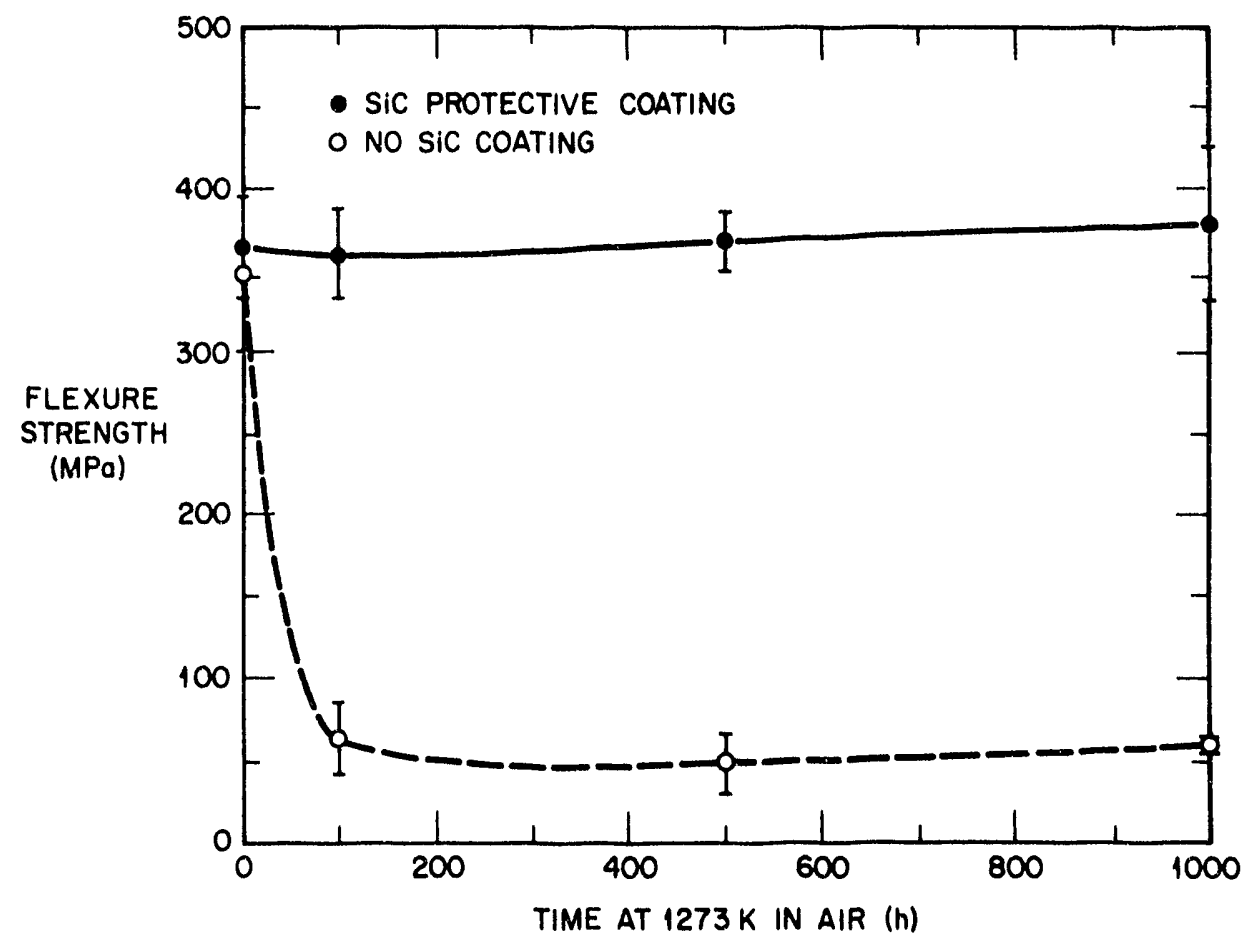

Fig. 2.1-2. The effect of oxidation in air at $1273 \mathrm{~K}$ on the flexure strength of Nicalon/SiC composites with a carbon interlayer.

ORNL-DWG $90-12036$

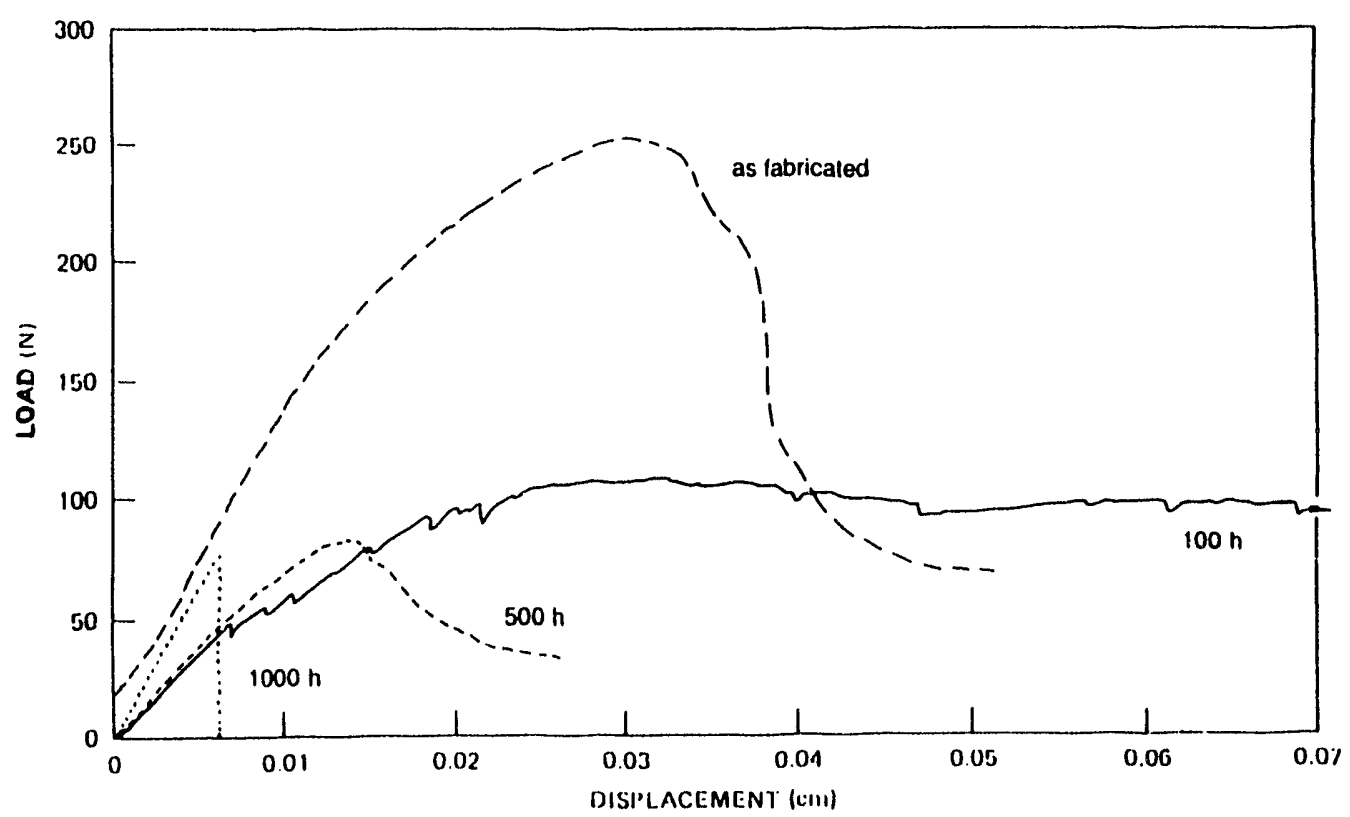

Fig. 2.1-3. The progressive effects of oxidation on the flexure behavior of unprotected specimens, time in $h$ indicated on curves. 

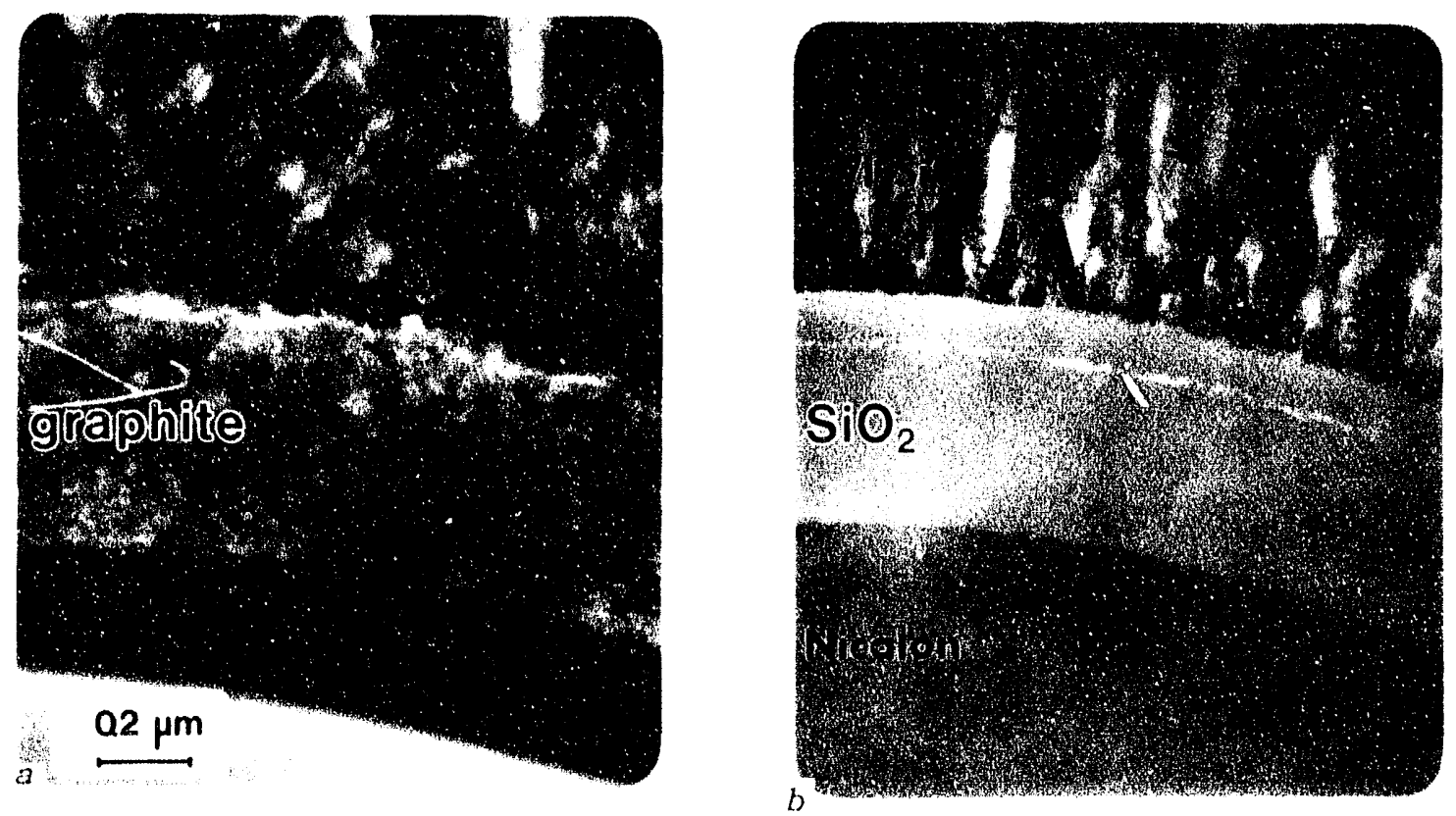

Fig. 2.1-4. TEM micrographs of the interface region for oxidized composites (a) with and (b) without a $\mathrm{SiC}$ external layer.

\subsubsection{Corrosion in Combustion Environments}

Exposure to the combustion products of natural gas and air at $1273 \mathrm{~K}$ resulted in strengths similar to those produced by oxidation in air (Fig. 2.1-5). However, the embrittlement of unprotected composites was much more rapid. After only 100 h exposure to the combustion environment, the composites without a SiC outer layer exhibited low strength and catastrophic, brittle fracture. TEM analysis again showed the carbon interlayer was removed and oxidation of the fibers and matrix resulted in the formation of an amorphous silica layer at the interface.

The presence of sulfur appeared to enhance the degradation of the strength for all specimens, with and without a $\mathrm{SiC}$ external coating. As for uncoated composites exposed to the combustion of natural gas in air without sulfur, the unprotected bars possessed low strength and no evidence of fiber pull-out. The strengths of the SiC-coated samples were slightly lower than all protected samples, regardless of exposure time and/or atmosphere (Fig. 2.1-5).

A thick glassy layer was formed on the surfaces of the specimens tested in a sodiumcontaining environment. The glass coating resulted from the corrosion to the protective $\mathrm{SiC}$ coating, and of the matrix and fibers for the unprotected specimens (Fig. 2.1-6). Unprotected 
specimens were weak and brittle. The carbon interlayer remained intact in SiC-coated samples and flexure strengths were only slightly decreased. Flexure strength data for the Na corrosion specimens is also presented in Fig. 2.1-1.

\subsubsection{Discussion}

The poor oxidation resistance of carbon is well known. ${ }^{20}$ Carbon begins to oxidize at temperatures around $700 \mathrm{~K}$ and oxidation is rapid in air at temperatures above $1173 \mathrm{~K}$. Oxidation rates of $\approx 10^{-3} \mathrm{~g} / \mathrm{cm}^{2}-\mathrm{min}$, or about $5 \mu \mathrm{m} / \mathrm{min}$, at $1273 \mathrm{~K}$ in air are typical for pyrolytic graphite. ${ }^{20}$ The oxidation of Nicalon ${ }^{\circledR} / \mathrm{SiC}$ composites begins by ittack of the carbon interface coating at exposed fiber ends. With the fibers lying in one direction, oxidation proceeds along the fiber lengths. Once the carbon is removed along the entire fiber length, the matrix and fiber oxidize to form a silica layer that eventually bonds the components together. The strong bond at the fiber-matrix interface does not permit debonding and sliding, resulting in brittle behavior. Also, oxidation degrades the properties of the fiber, enhancing the embrittlement of the composite.

This type of "pipeline" oxidation has been observed in similar composite systems. $5,21,22$ In contrast, the carbon interlayer remained unchanged in specimens with a $\mathrm{SiC}$ surface coating after 1000 hours. The ends of the fibers were not exposed, thus hindering oxidation of the carbon interlayer and composite constituents.

A distinct boundary was detected in the amorphous silica layer that was formed at the fiber-matrix interface. It is speculated that this interface, which appeared to be positioned similarly in all highly corroded specimens, was present due to the difference in the oxidation rates of the fibers and matrix. The oxidation rate of CVD SiC is extremely slow at temperatures below $1473 \mathrm{~K} \cdot{ }^{17,23,24}$ Only a very thin oxidation layer (noted as a slight discoloration of the surfaces) was observed for all heat-treated composites with the exception of those exposed to a sodium-containing atmosphere. Conversely, the Nicalon ${ }^{\circledR}$ fibers, composed of $\mathrm{SiC}, \mathrm{SiO}_{2}$, and $\mathrm{C}$, oxidize more rapidly, producing a thicker $\mathrm{SiO}_{2}$ layer than at the matrix surface. ${ }^{25,26}$

The oxidation rates of both $\mathrm{SiC}$ and $\mathrm{C}$ are accelerated by the presence of water vapor or sulfur. ${ }^{16,17}$ The unprotected samples, exposed to the combustion products of natural gas and air at $1273 \mathrm{~K}$, which contains approximately $15 \mathrm{vol} \%$ water vapor, exhibited brittle failure after only $100 \mathrm{~h}$. The presence of sulfur produced an addition decrease in strength in all exposed specimens. Microprobe analysis found sulfur in small segregated pockets along the 
ORNL-DWG 91-12950

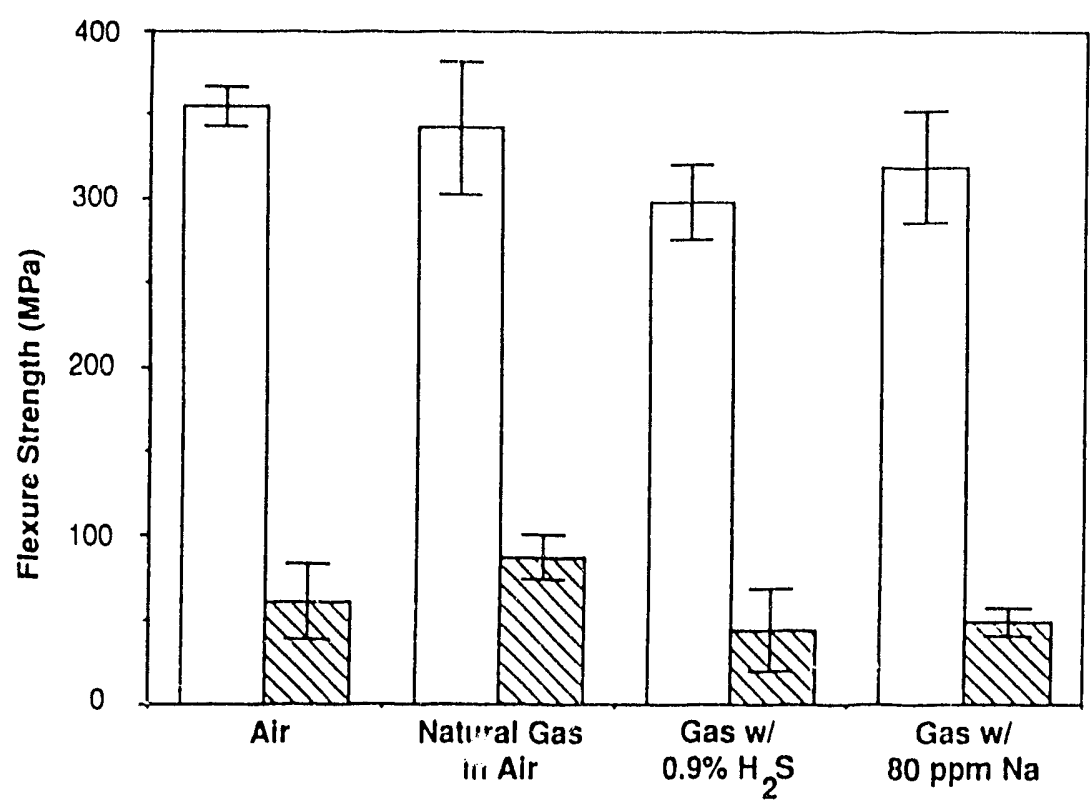

Temperature $=1273 \mathrm{~K}$

Exposure Time $=100$ hours

$\square$ SiC Seal Coated

$\triangle$ Uncoated

Fig. 2.1-5. Comparison of composite flexure strengths after $100 \mathrm{~h}, 1273 \mathrm{~K}$ exposures to various corrosion environments.

YP10737
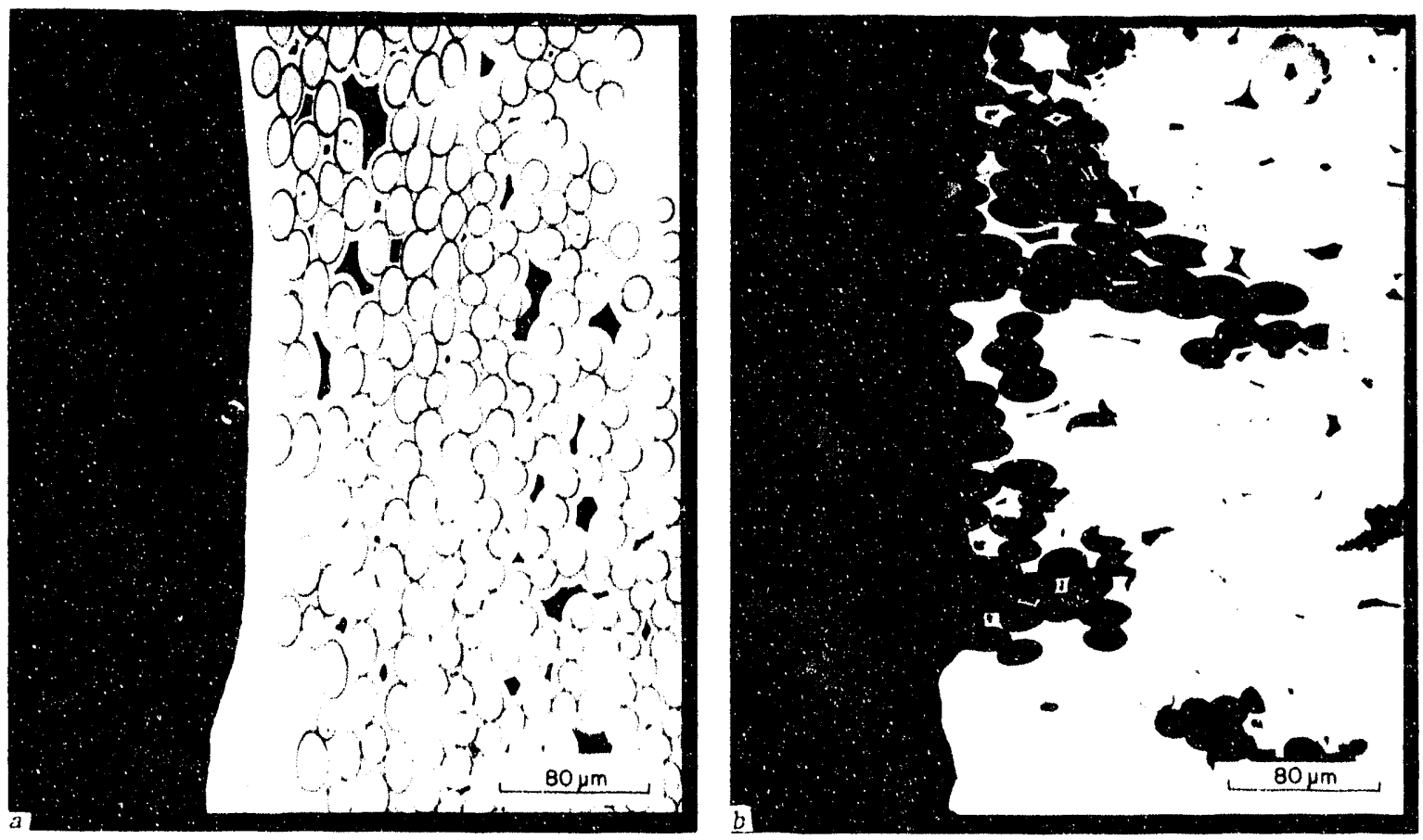

Fig. 2.1-6. Micrograph of glass layer formed during exposure to Na-containing combustion atmosphere; (a) SiC protective coating, and (b) unprotected. 
fiber-matrix interface. The limited distribution of sulfur throughout the composite structures and components makes the degradation mechanisms difficult to determine.

Sodium additions to the test environment produced very thick glass layers on the surface of the specimens. Alkali oxides such as soda, $\mathrm{Na}_{2} \mathrm{O}$, react with silicon-based materials to form low-melting point phases. ${ }^{19}$ When the normally protective silica surface film is contaminated with $\mathrm{Na}_{2} \mathrm{O}$, a lower melting temperature glass with higher oxygen diffusivity results. This allows oxidation to proceed more quickly at the $\mathrm{SiO}_{2} / \mathrm{SiC}$ interface, causing rapid recession and consumption of the $\mathrm{SiC}$. This effect was most evident for the unprotected specimens where oxidation of the carbon interlayer and composite constituents proceeded quickly in the Na-containing atmosphere. Extensive consumption of the fibers and matrix near the external surfaces was observed. The SiC external coating appeared to provide adequate protection for the interface, and the fibers and matrix in these limited exposures. However, it is clear that continued exposure would result in gross corrosion of the protective SiC surface coating and finally the composite, resulting in a significant degradation of performance.

\subsubsection{Conclusions}

Investigation of the effects of oxidation and corrosion of Nicalon ${ }^{\circledast} / \mathrm{SiC}$ composites with a carbon interlayer confirmed the need for a protective external coating. The mechanical properties of uncoated composite samples were degraded after only $100 \mathrm{~h}$ of exposure at $1273 \mathrm{~K}$ in air. It appears this is due to the complete oxidation of the carbon interlayer throughout the composite specimens. Longer exposure produced brittle behavior as the fibers and matrix oxidized to form a silica interlayer, strongly bonding the components together. A CVD SiC coating, however, protected the composites against oxidation by sealing off the exposed fibers on the surface of the sample.

Combustion environments hastened the embrittlement of unprotected samples. Water vapor and sulfur accelerated the oxidation process. Exposure to sodium weakened the composites by reacting with the ceramic components to form a soda-glass corrosion product. The rapid consumption of the composites in the Na-containing atmosphere indicated that although the $\mathrm{SiC}$ seal coating is helpful in oxidizing atmospheres, it will likely not be resistant to long term attack by sodium at elevated temperatures.

\subsubsection{References}

1. D. P. Stinton, A. J. Caputo, and R. A. Lowden, "Synthesis of Fiber-Reinforced SiC Composites by Chemical Vapor Infiltration," Am. Ceram. Soc. Bull. 65(2), 347-350 (1986). 
2. R. A. J. Sambell, A. Briggs, D. C. Phillips, and D. H. Bowen, "Carbon Fiber Composites with Glass and Glass-Ceramic Matrices, Part 2: Continuous Fibers,"

J. Mater. Sci. 7, 676-681 (1972).

3. K. M. Prewo, and J. J. Brennan, "High-Strength Silicon Carbide Fiber-Reinforced Glass-Matrix Composites," J. Mater. Sci. 15, $463-468$ (1980).

4. K. M. Prewo, J. J. Brennan, and G. K. Layden, "Fiber-Reinforced Glasses and Glass-Ceramics for High Performance Applications," Ceram. Bull. 65(2), 305-322 (1986).

5. T. Mah, M. G. Mendiratta, A. P. Katz, and K. S. Mazdiyasni, "Recent Developments in Fiber-Reinforced High Temperature Ceramic Composites," Ceram. Bull. 66(2), 304-317 (1987).

6. A. J. Caputo, D. P. Stinton, R. A. Lowden, and T. M. Besmann, "Fiber-Reinforced SiC Composites with Improved Mechanical Properties," Am. Ceram. Soc. Bull. 66(2), 268-272 (1987).

7. B. Budiansky, J. W. Hutchinson, and A. G. Evans, "Matrix Fracture in FiberReinforced Ceramics," J. Mech. Phys. Solids 34(2), 167-189 (1986).

8. R. A. Lowden, Characterization and Control of the Fiber-Matrix Interface in Cieramic Matrix Composites, ORNL/TM-11039, Oak Ridge National Laboratory, Oak Ridge, TN (March 1989).

9. R. A. Lowden, and K. L. More, "The Effect of Fiber Coatings on Interfacial Shear Strength and the Mechanical Behavior of Ceramic Composites," MRS Symposium Proceedings, Vol. 170, Tailoring Multiphase and Composite Ceramics (March 1989).

10. J. J. Brennan, "Interfacial Characterization of Glass and Glass-Ceramic Matrix/Nicalon ${ }^{\circledR}$ SiC Fiber Composites," MRS Proceedings, Vol. 20, Tailoring Multiphase and Composite Ceramics, ed. R. E. Tressler et al., Plenum Publishing Corporation, pp. 549-560 (1986).

11. T. M. Besmann, R. A. Lowden, D. P. Stinton, and T. L. Starr, "A Method for the Rapid Chemical Vapor Infiltration of Ceramic Composites," J. de Physique 5(50), Colloque C5, 229-239 (1989).

12. P. Hancock, "The Use of Laboratory and Rig Tests to Simulate Gas Turbine Corrosion Problems," Corrosion Science 22(1), 51-65 (1982).

13. N. S. Jacobson, C. A. Stearns, and J. L. Smialek, "Burner Rig Corrosion of SiC at $1000^{\circ} \mathrm{C}, "$ Advanced Ceramic Materials 1(2), 154-161 (1986).

14. D. S. Fox, and J. L. Smialek, "Burner Rig Hot Corrosion of Silicon Carbide and Silicon Nitride," J. Amer. Ceram. Soc. 73(2), 303-311 (1990). 
15. T. C. Tiearney, Jr., and K. Natesan, "Sulfidation-Oxidation of Advanced Metallic Materials on Simulated Low-Btu Coal Gasifier Environments," Oxidation of Metals 17(1/2), 1-25 (1982).

16. I. A. Yavorskii, V. I. Elchin, and G. G. Gnesin, "Reactions of Silicon Carbide with Oxidizing Atmospheres," Soviet Powder Metallurgy and Metal Ceramics 17, 542-545 (1978).

17. D. W. McKee, and D. Chatterji, "Corrosion of Silicon Carbide in Gases and Alkaline Melts," J. Am. Ceram. Soc. 59(9-10), $441-444$ (1976).

18. J. I. Federer, "Corrosion of $\mathrm{SiC}$ by $\mathrm{Na}_{2} \mathrm{SO}_{4}$," Advanced Ceramic Materials 3(1), 5661 (1988).

19. R. H. Jones, C. H. Henager, Jr., P. P. Trzaskoma, N. S. Stoloff, T. P. Moffat, and B. D. Lichter, "Environmental Effects on Advanced Materials," Journal of Metals, 19-30 (December 1988).

20. J. E. Hove, and W. C. Riley, "Graphite," pp. 14-76 in Ceramics for Advanied Technologies, John Wiley and Sons, New Yoik, New York (1965).

21. N. Fretty, and M. Boussuge, "Relationship Between High-Temperature Development of Fiber-Matrix Interfaces and the Mechanical Behavior of SiC-SiC Composites," Composites Science and Technology 37, 177-89 (1990).

22. E. Menessier, A. Guette, R. Pailler, R. Naslain, L. Rabardel, B. Hosten, T. Macke, and P. Lespade, "Thermo-mechanical Characterization of Ceramic Composites Made of a LAS Glass-Ceramic Reinforced with Silicon Carbide Fibers," pp. 121-127 in Proceeding of the Third European Conference on Composite Materials, A. R. Bunsell, P. Lamicq, and A. Massiah, Elsevier Applied Science (1989).

23. B. Frisch, W. R. Thiele, R. Drumm, and B. Münnich, "On the Oxidation Mechanisms of Silicon Carbicie in the 300 to $1300^{\circ} \mathrm{C}$ Temperature Range," CFI/Ber. 65(8/9), 277-284 (1988).

24. G. H. Shiroky, "Oxidation Behavior of Chemically Vapor Deposited Silicon Carbide," Advanced Ceramic Materials 2(2), 137-141 (1987).

25. A. S. Fareed, P. Fang, M. Koczak, and F. Ko, "Thermochemical Properties of SiC Yarn," Ceram. Bull. 66(2), 353-358 (1987).

26. T. J. Clark, M. Jaffe, J. Rabe, and N. R. Langley, "Thermal Degradation of Nicalon SiC Fibers," Ceram. Eng. Sci. Proc. 6(7-8), 576-588 (1985).

\subsubsection{Microwave Sintering of Lanthanum Chromite - M. A. Janney and H. D. Kimrey}

Sintering and annealing of a lanthanum chromite composition is described. In contrast to previous microwave sintering investigations on alumina and zirconia, no "microwave effect" was observed in the lanthanum chromite system. That is, there was no acceleration of 
densification or microstructure development by the microwave field. The high electronic conductivity of the lanthanum chromite is hypothesized to be responsible for lack of a "microwave effect" in this system.

One of the key components of the monolithic solid oxide fuel cell (MSOFC) is the material that acts as the electrical interconnection between stacks of electrolytic cells. In most configurations, the interconnect material is based on $\mathrm{LaCrO}_{3}{ }^{1} \mathrm{LaCrO}_{3}$ meets all of the requirements for the interconnect material; it has high electronic conductivity, is stable in both oxidizing and reducing atmospheres, and can be sintered to high density, in air, with the appropriate additions of cation dopants such as $\mathrm{Ca}$ or $\mathrm{Sr}^{2}{ }^{2}$ In our current studies, we are surveying the microwave processing of several MSOFC materials. A previous paper ${ }^{3}$ showed that significant advantages were obtained from microwave firing of $\mathrm{ZrO}_{2}-8$ mol \% $\mathrm{Y}_{2} \mathrm{O}_{3}$, including lowering the sintering temperature by $\sim 150^{\circ} \mathrm{C}$ and producing a finer grain size in the final fired piece. It was the intent of this work to investigate the role of microwave processing on the firing of $\mathrm{LaCrO}_{3}$ and to see of similar benefits would obtain.

A major difference between the zirconia and the $\mathrm{LaCrO}_{3}$ systems is in their electrical conductivities. Zirconia is an ionic conductor at the MSOFC operating temperature of $1000^{\circ} \mathrm{C}$ but $\mathrm{LaCrO}_{3}$ is an electronic conductor (actually a semiconductor). Furthermore, the change in conductivity with temperature is significantly different for the two materials. At ambient temperature, zirconia is an excellent insulator (resistivity $>10^{10} \mathrm{ohm}-\mathrm{cm}$ ) whereas $\mathrm{LaCrO}_{3}$ is a fair conductor (resistivity $\sim 10^{2} \mathrm{ohm}-\mathrm{cm}$ ); however, at $1000^{\circ} \mathrm{C}$, zirconia has an ionic resistivity of only $\sim 10 \mathrm{ohm}-\mathrm{cm}$ whereas $\mathrm{LaCrO}_{3}$ has a resistivity of $\sim 1 \mathrm{ohm}-\mathrm{cm}$. Therefore, the change in resistivity for zirconia is $\sim 10$ orders of magnitude; but, for $\mathrm{LaCrO}_{3}$ it is only $\sim 2$ orders of magnitude. This has a profound effect on microwave processing. As was shown previously, ${ }^{3}$ zirconia is difficult to process by direct microwave heating because of thermal runaway. A combination of high thermal resistance and rapid change in microwave absorbance (caused by its extreme change in conductivity with temperature) creates "hot spots" in the zirconia that lead to highly localized sintering. $\mathrm{LaCrO}_{3}$ should be easier to process because its electrical properties do not change as rapidly as do those of zirconia and because its thermal conductivity is much higher, which together should prevent the formation of "hot spots" in the material.

Microwave firing of ceramics is an emerging process technology which holds the promise of accelerated firing schedules and greater control over microstructure. ${ }^{3,4,6}$ However, a scientific basis to explain anomalous effects such as enhanced sintering and diffusion ${ }^{3 \cdot 6}$ does 
not exist. Furthermore, the technological understanding required to use microwaves effectively in processing materials is often lacking. The interactions between microwave radiation and the materials being processed have to be taken into account in planning and executing experiments; these interactions are often unknown or unquantified. Also, the effects of the microwave field on the insulation, the thermocouples, and the setters that are used must be considered. ${ }^{7}$

\subsubsection{Microwave Firing Procedure}

The sintering experiments were conducted using a technique that was developed in our previous work. ${ }^{3-5}$ The part to be sintered was buried in bulk zirconia fiber (ZYBF), ${ }^{2}$ which was contained in a crucible made of an alumina castable insulating refractory. ${ }^{b} \mathrm{~A} 1 / 8$ in. $(0.3 \mathrm{~cm})$ diam platinum-sheathed, Type $S$ thermocouple embedded in a $1 / 4$ in. $(0.6 \mathrm{~cm})$ diam by $1 / 2 \mathrm{in} .(1.2 \mathrm{~cm})$ deep hole in the part was used to measure the temperature. The platinum sheath shielded the thermocouple wires from the microwave field, thus reducing the tendency for arcing from the thermocouple; bare thermocouple wires would arc continually. The zirconia bulk fiber was used for two reasons. First, ZYBF is chemically compatible with $\mathrm{LaCrO}_{3}$, which few other refractories are. Second, ZYBF has a relatively high microwave loss, which was reasonably close to the loss properties of the $\mathrm{LaCrO}_{3}$ sample. Our experience has shown that it is desirable to match the heating characteristics of the first-wall insulation with those of the sample to avoid producing an inverse temperature gradient in the sample (i.e., the center hotter than the surface). The alumina castable crucible acted as the primary thermal insulation because it was heated very little in the $2.45 \mathrm{GHz}$ microwave field. Comparison furnace sintering runs were conducted in a conventional, air-fired furnace. ${ }^{c}$ Samples were fired in an alumina boat while sitting on a zirconia fiberboard setter (ZYBF), and were covered by an alumina crucible (not in contact with the sample) to reduce $\mathrm{Cr}$ evaporation from the sample.

Arcing between the platinum sheath of the thermocouple and the sample was observed during our initial investigation. The evidence for arcing was two-fold: (1) direct observation of the tip of the thermocouple revealed that the metal sheath was heavily pitted and locally

\footnotetext{
'Zircar Products, Inc., Florida, N.Y.

${ }^{b} \mathrm{~K} 3300$ Castable, Thermal Ceramics, Augusta, Ga.

'Model EHSK-12, Keith Co., Inc., Pico Rivera, Ca.
} 
melted in certain regions; and (2) the temperature and power fluctuated wildly during the heatup phase of the sintering run. Arcing between the sample and the thermocouple sheath was not unexpected given the high conductivity of the sample. Arcing caused the tip of the thermocouple to heat excessively, which produced a series of upward spikes in the temperature profile. Because the rapid heating pushed the thermocouple temperature well above the controller setpoint, the furnace controller shut off the power, the arcing stopped, and the temperature of the thermocouple tip dropped rapidly. Since the thermocouple temperature was now below the setpoint temperature of the furnace controller, power was reapplied and arcing resumed. Thus a rapid periodic temperature fluctuation was established, Fig. 2.1-7. Note that the magnitude of the fluctuation increased with incre .ng temperature. It is desirable that arcing be avoided during microwave processing because it represents a major

ORNL-DWG $91-9724$

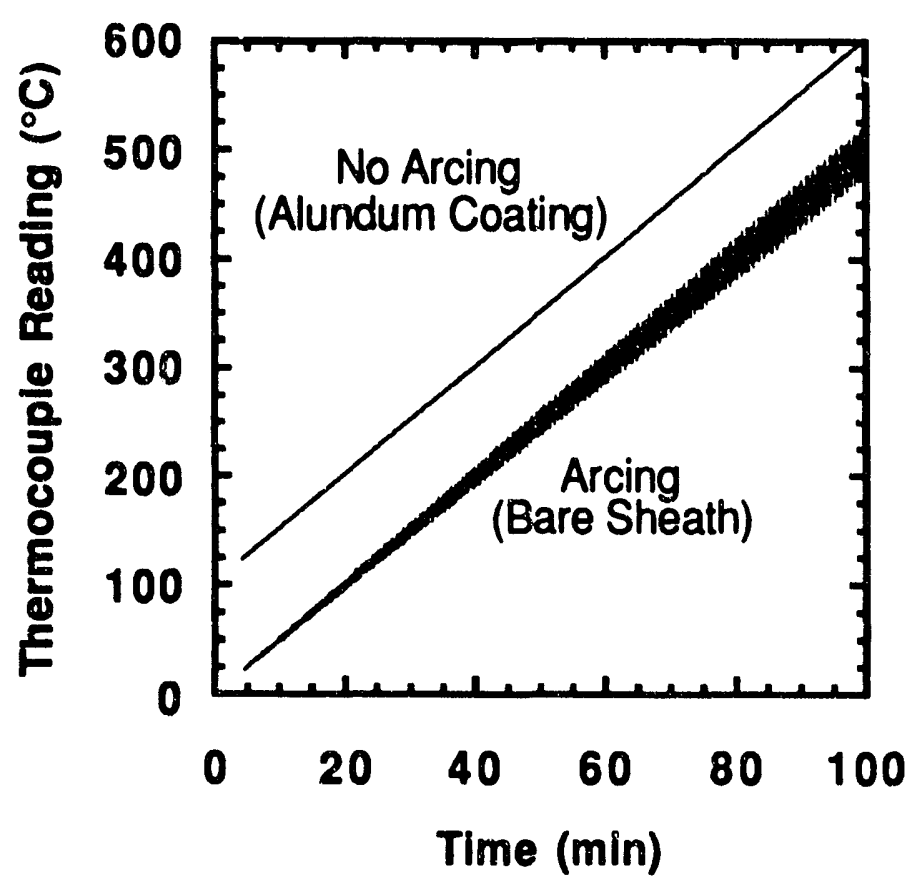

Fig. 2.1-7. Arcing between the platinum sheath of the thermocouple and the $\mathrm{LaCrO}_{3}$ sample was indicated by erratic readings from the thermocouple. The problem was corrected by coating the platinum sheath with alundum cement. The time-temperature trace for the "no arcing" condition has been shifted by $100^{\circ} \mathrm{C}$ for clarity. 
perturbation of the microwave field, and therefore produces significant non-uniformities in the heating of the part. To prevent arcing, a dielectric barrier was placed between the thermocouple sheath and the sample, which reduced the electric field strength in that region, and hence the propensity to arcing. This was accomplished by coating the platinum thermocouple sheath with a layer of Alundum ${ }^{d}$ cement. The resulting furnace run using the alundum-coated Pt-sheathed thermocouple is shown as the top trace in Fig. 2.1-7. The microwave power-time traces (not shown) mimicked the temperature-time curves in both cases; i.e., the trace was irregular for the arcing case and smooth for the non-arching case. No further evidence of arching was observed.

\subsubsection{Material Selection and Processing}

A doped lanthanum chromite ${ }^{e}$ with the composition $\left(\mathrm{La}_{0.79} \mathrm{Ca}_{0.2}\right)\left(\mathrm{Cr}_{0.9} \mathrm{Co}_{0.1}\right) \mathrm{O}_{3}$ was used in this investigation. This composition was chosen because it is sinterable in conventional air furnaces ${ }^{2}$ at $1450-1500^{\circ} \mathrm{C}$ and because it is currently being used in fuel cell development programs. ${ }^{10}$ Samples 1.0 in. $(2.5 \mathrm{~cm})$ diam by $3 / 4 \mathrm{in} .(1.8 \mathrm{~cm})$ high were die pressed at $7 \mathrm{kpsi}$ $(50 \mathrm{MPa})$, then isopressed at $30 \mathrm{kpsi}(210 \mathrm{MPa})$.

\subsubsection{Temperature Measurement}

As was indicated in the Experimental Procedure section, arcing of the thermocouple to the sample was initially a problem. This prompted us to question whether there were other problems associated with the measurement of temperature in these experiments. To test our temperature measurement capability, an experiment was designed whereby temperature was monitored with both a thermocouple and a 2-color infrared pyrometer.

Figure 2.1-8 shows the details of the experimental setup. A 1 in. $(2.5 \mathrm{~cm})$ diam by $3 / 4$ in. $(1.9 \mathrm{~cm})$ tall green lanthanum chromite pellet was used. A thermocouple well, 1/4 in. $(0.6 \mathrm{~cm})$ diam by $1 / 2$ in. $(1.2 \mathrm{~cm})$ deep was drilled into the bottom of the green sample for insertion of the platinum-sheathed, Type $S$ thermocouple. A pyrometer sight hole, $\sim 5 / 16$ in. $(0.8 \mathrm{~cm})$ diam, was drilled into the side of the sample and a $1 / 4 \mathrm{in} .(0.6 \mathrm{~cm})$ diam alumina sight

\footnotetext{
${ }^{\mathrm{J}}$ Fisher Scientific, Pittshurgh.

'HUA Assoc., Rolla, Mo.
} 
ORNL-DWG 91-9725

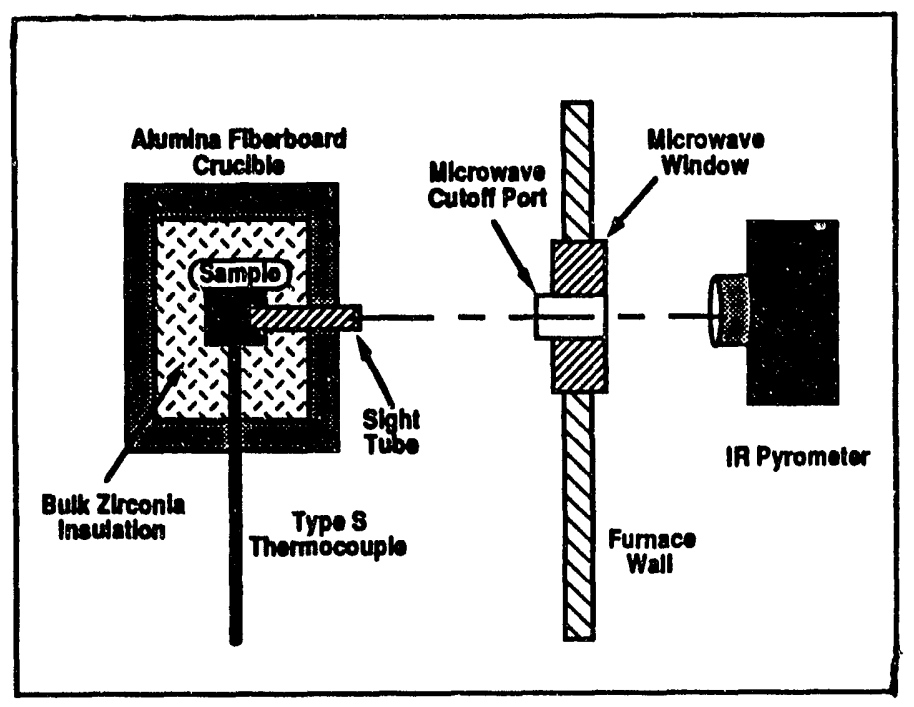

Fig. 2.1-8. Setup for simultaneous measurement of the temperature of a $\mathrm{LaCrO}_{3}$ pellet fired in a microwave furnace by thermocouple and infrared pyrometer.

tube was inserted into the sample through an alumina insulating cylinder ${ }^{f}$ and through the ZYBF that surrounded the part. The regions where the temperatures were being measured by the two methods were less than $1 / 4$ in. $(0.6 \mathrm{~cm})$ apart and therefore represented essentially the same volume within the sample. On heating in the ORNL \#2 furnace, excellent agreement was obtained between the temperature readings of the thermocouple and the 2-color infrared pyrometer. During the soak period, the thermocouple reading was between 1301 and $1306^{\circ} \mathrm{C}$ and the pyrometer reading varied from 1300 to $1310^{\circ} \mathrm{C}$. We conclude, therefore, that our temperature measurements were essentially correct.

\subsubsection{Sintering of $\mathrm{LaCrO}_{3}$ Matcrials}

Figure 2.1-9 is a densification curve for the composition $\left(\mathrm{La}_{0.79} \mathrm{Ca}_{0.2}\right)\left(\mathrm{Cr}_{0.9} \mathrm{Co}_{0.1}\right) \mathrm{O}_{3}$ which compares the sintering behavior for conventional and microwave sintering. Samples were heated at $10^{\circ} \mathrm{C} / \mathrm{min}$ to the sintering temperature and held for $1 \mathrm{~h}$ at temperature. The sintering response of the lanthanum chromite to the two methods of heating was similar; no enhancement of densification by microwave firing was observed. The microstructure of the $\left(\mathrm{La}_{0.79} \mathrm{Ca}_{0.2}\right)\left(\mathrm{Cr}_{0.9} \mathrm{Co}_{0.1}\right) \mathrm{O}_{3}$ sintered at $1400^{\circ} \mathrm{C}$ for $1 \mathrm{~h}$ consisted of a major phase of primary

'Zircar Products, Inc., Florida, N.Y. 
idiomorphic grains (primarily rectangular prisms) of $\mathrm{LaCrO}_{3}$ solid solution surrounded by an intergranular liquid phase, together with $\sim 6 \%$ porosity. The primary grains contained mainly $\mathrm{La}$ and $\mathrm{Cr}$, as one would expect from a $\mathrm{LaCrO}_{3}$ composition, with a small amount of $\mathrm{Ca}$ and Co. However, there was a second feature to these grains. Most of them were "cored"; i.e., the center of the grains was rich in La and poor in Ca, Table 2.1-3. Coring was observed in both the microwave and the conventionally fired samples. The intergranular liquid phase was essentially a cobalt oxide melt with 5 to 10 cation $\% \mathrm{Cr}$, and trace amounts of La and $\mathrm{Ca}$. In the samples fired at $1300^{\circ} \mathrm{C}$ in the microwave furnace, two different liquid phase compositions were found, presumably because the temperature achieved during sintering was not high enough to homogenize the microstructure. To investigate the process of homogenization, long-term annealing studies were conducted under both conventional and microwave firing conditions. Samples were annealed at 1400,1450 , and $1500^{\circ} \mathrm{C}$ for $48 \mathrm{~h}$ in both the $2.45 \mathrm{GHz}$ microwave furnace and in the conventional furnace. Table 2.1-4 shows that there was essentially no difference in the fired densities of the samples. Typical microstructures for both conventional and microwave annealing conditions at $1450^{\circ} \mathrm{C}$ are shown in Fig. 2.1-10. Some, but not all, of the idiomorphic shape of the primary lanthanum chromite grains has been lost during the long-term anneal. Pockets of liquid phase which are high in $\mathrm{CoO}$ remain in both of the samples shown in Fig. 2.1-10. The microstructures of the 1400 and $1500^{\circ} \mathrm{C}$ annealed samples were similar to those shown in Fig. 2.1-10 except that the degree of coarsening was less $\left(1400^{\circ} \mathrm{C}\right)$ or more $\left(1500^{\circ} \mathrm{C}\right)$. None of the experimental evidence suggests that there is a significant difference between the lanthanum chromite microstructures produced by conventional asd microwave firing. These results raise significant questions regarding why the "microwave effect" is essentially absent in the lanthanum chromite system.

It has been shown that microwave heating of alumina (at $28 \mathrm{GHz}$ ) and zirconia (at $2.45 \mathrm{GHz}$ ) accelerates densification, ${ }^{3,4,6}$ grain growth, ${ }^{5}$ and oxygen diffusion ${ }^{4}$ in these materials. The mechanisms by which microwaves interact with these materials are not well understood. They are, however, related to the ionic defects present in these predominantly ionic materials. For example, $\mathrm{Ho}^{9}$ has demonstrated for the case of aluminum oxide that, for materials of similar purity, single crystal sapphire has much lower loss than does polycrystalline alumina. It was concluded in his study that the grain boundaries, which are essentially large planar ionic defects, are the sites of most of the microwave absorption in the polycrystalline alumina. A similar mode of microwave absorption was hypothesized for other ionically coupling materials. 
ORNL-DWG 90-17102

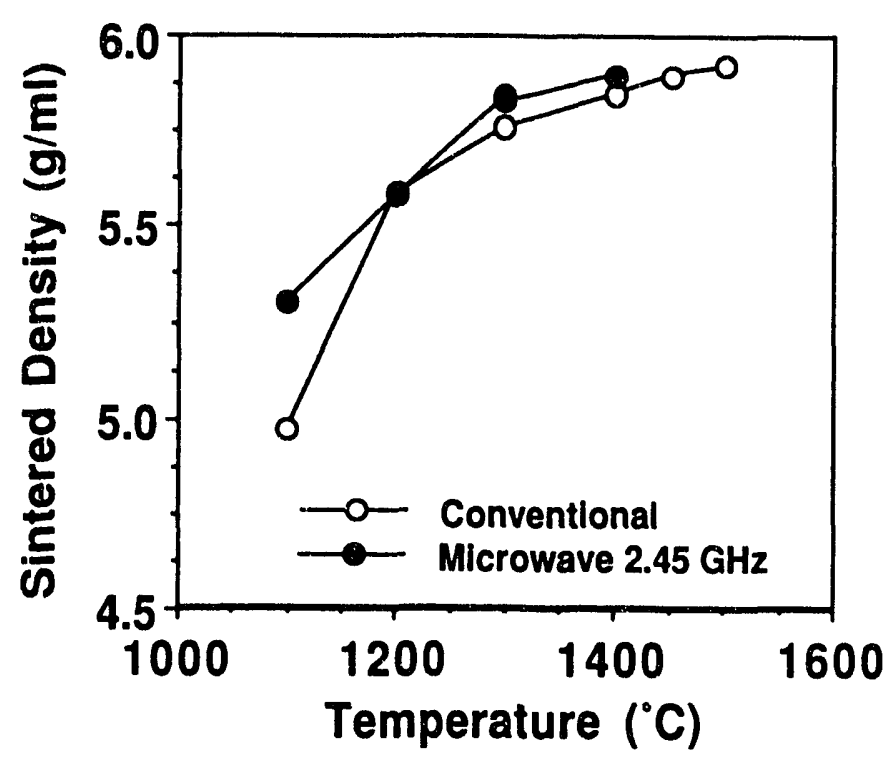

Fig. 2.1-9. There was little difference between conventional and microwave sintering of $\left[\left(\mathrm{La}_{0.79} \mathrm{Ca}_{0.2}\right)\right.$ $\left.\left(\mathrm{Cr}_{0.9} \mathrm{Co}_{0.1}\right) \mathrm{O}_{3}\right]$ systems.

Table 2.1-3. Compositional differences existed among phases processed under different conditions in the lanthanum chromite

$\left.\left[\left(\mathrm{La}_{0.79} \mathrm{Ca}_{0.2}\right)\left(\mathrm{Cr}_{0.9} \mathrm{Co}_{0.1}\right) \mathrm{O}_{3}\right)\right]$ system

\begin{tabular}{|c|c|c|c|c|c|c|c|}
\hline \multirow[t]{2}{*}{ Feature } & \multirow{2}{*}{$\begin{array}{r}\text { Time } \\
(\mathrm{h})\end{array}$} & \multirow{2}{*}{$\begin{array}{l}\text { Temp } \\
\left({ }^{\circ} \mathrm{C}\right)\end{array}$} & \multirow[t]{2}{*}{ Sample * } & \multicolumn{4}{|c|}{ Cation Concentratior. } \\
\hline & & & & $\frac{\mathrm{La}}{(8)^{*}}$ & $\frac{\mathrm{Ca}}{(8)}$ & $\frac{\mathrm{Cr}}{(8)}$ & $\frac{\text { Co }}{(8)}$ \\
\hline \multicolumn{8}{|c|}{ Matrix Composition } \\
\hline MW & 1 & 1300 & LMW90002 & 37.6 & 8.7 & 49.5 & 4.2 \\
\hline MW & 48 & 1400 & LMW90010 & 40.2 & 9.5 & 46.3 & 4.0 \\
\hline Conventional & 1 & 1500 & LC90005 & 38.9 & 9.2 & 47.7 & 4.2 \\
\hline Conventional & 48 & 1400 & LC90008 & 38.3 & 10.0 & 47.9 & 3.7 \\
\hline \multicolumn{8}{|c|}{ Precipitate Composicion } \\
\hline MW & 48 & 1400 & LMW90010 & 45.8 & 4.31 & 47.3 & 2.6 \\
\hline Conventional & 1 & 1400 & LC, 90003 & 43.7 & 5.2 & 45.7 & 5.4 \\
\hline Conventional & 48 & 1400 & LC90008 & 43.9 & 5.5 & 46.7 & 3.9 \\
\hline \multicolumn{8}{|c|}{ Liquid Phase Composition } \\
\hline \multirow[t]{3}{*}{ MW, $1 \mathrm{~h}$} & 1 & 1300 & LMW90002 & & & & \\
\hline & & & Liquid \#1 & 9.7 & 2.6 & 46.3 & 41.4 \\
\hline & & & Liquid \#2 & 2.9 & 0.7 & 7.4 & 89.0 \\
\hline Conventional & 1 & 1400 & LC90003 & 5.5 & 1.5 & 9.8 & 83.3 \\
\hline Conventional & 48 & 1400 & LC90008 & 0.7 & 1.0 & 4.4 & 93.9 \\
\hline
\end{tabular}


Table 2.1-4. Sintered densities for $48 \mathrm{~h}$ lanthanum chromite annealing study

\begin{tabular}{lccl}
\hline Sample \# & $\begin{array}{c}\text { Temperature } \\
\left({ }^{\circ} \mathrm{C}\right)\end{array}$ & $\begin{array}{c}\text { Microwave/ } \\
\text { Conventional }\end{array}$ & $\begin{array}{c}\text { Density } \\
\left(\mathrm{g} / \mathrm{cm}^{3}\right)\end{array}$ \\
\hline LMW91003 & 1400 & MW & 6.20 \\
LMW91001 & 1450 & MW & 6.16 \\
LMW91002 & 1500 & MW & 6.12 \\
& & & \\
LC91005 & 1400 & CONV & 6.15 \\
LC91001 & 1450 & CONV & 6.2 \\
LC91002 & 1500 & CONV & 6.07 \\
\end{tabular}

In the case of $\mathrm{LaCrO}_{3}$, the coupling mechanism is due to the interaction of the microwave electric field with the electronic charge carriers, as occurs for microwave interactions with metals rather than with ionic charge carriers. Hence, in the case of alumina and zirconia, the microwaves can interact directly with the defects that are involved in mass transport processes; but, in the caseof $\mathrm{LaCrO}_{3}$, the microwave field instead acts directly on the electrons but only indirectly, in the form of hea', on the defects. That the "microwave effect" is largely absent in the $\mathrm{LaCrO}_{3}$ system may $\mathrm{t}_{\mathrm{i}}^{\mathrm{a}} \mathrm{-n}$ be understood in terms of the electronic coupling that exists as compared with the large "microwave effect" that exists for systems such as alumina and zirconia, which exhibit coupling to the ionic defects.

The results obtained herein for lanthanum chromite have important implications for microwave processing of other electronically conducting materials. By analogy with the chromite system, other conducting oxide systems will probably show little benefit from microwave processing. These materials include other chromites, vanadites, ferrites, cobaltites, and ruthenites. ${ }^{12}$ One can extend the range of prediction to include the effect of microwaves on other conducting materials such as metals and refractory carbides, nitrides, borides, and silicides. One must be careful in extending the analogy, however, since many materials shade gradually from one type of behavior to another. Take for example the case of zirconium oxide. There is a gradual change properties as one moves from the stoichiometric $\mathrm{ZrO}_{2.00}$ to a substoichiometric $\mathrm{ZrO}_{2-x}$ (both of which are ionic conductors), through various intermediate phases eventually to the fully metallic $\mathrm{ZrO}_{1 \pm}$. At what point in the composition range will the "microwave effect" be diminished or disappear is not at all clear. 
YP11523
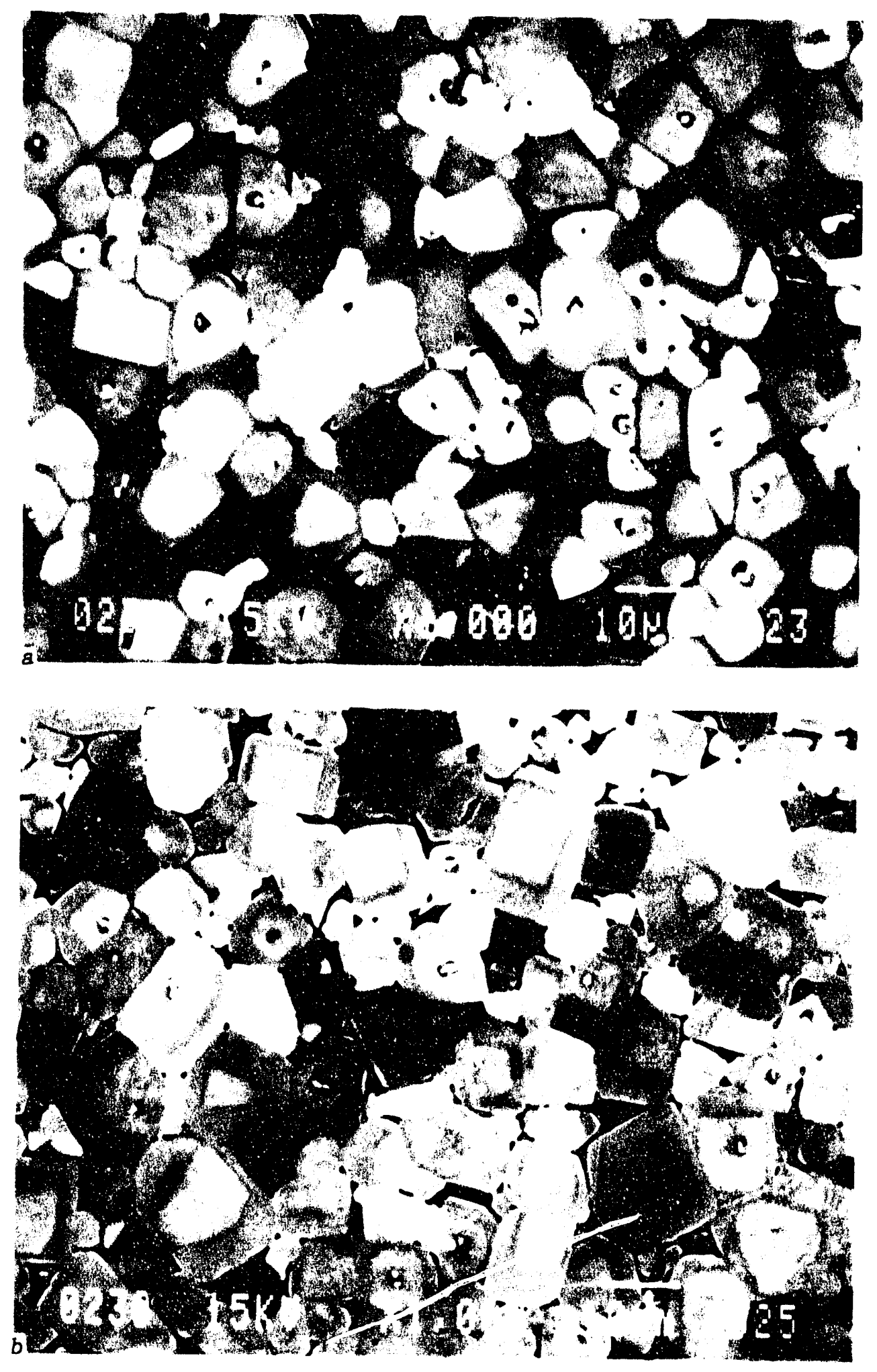

Fig. 2.1-10. The microstructures of the microwave and conventionally-fired samples were similar after annealing at $1450^{\circ} \mathrm{C}$ for $48 \mathrm{~h}$ : (a) microwave; (b) conventional. Scanning electron micrograph, back-scattered electron mode; $1000 \mathrm{X}$ magnification. 
Lanthanum chromite was an easy material to fire in a $2.45 \mathrm{GHz}$ microwave furnace. It couples well because of its relatively low electrical resistivity $(\sim 0.1 \mathrm{ohm}-\mathrm{cm}$ at ambient temperature). However, no "microwave effect" was observed for the system studied; i.e., there was no acceleration of densification or microstructural development in the system produced by microwave firing. This was in marked contrast to the large "microwave effects" that had been observed previously in systems such as alumina and zirconia. The differences have been attributed to the differences in the modes of coupling of the microwaves to the chromite system and the alumina and zirconia systems. In the chromite system, coupling is to the electronic charges carriers, which do not participate in mass transport processes. In the alumina and zirconia systems, coupling is to the ionic defects in the crystal, which are directly responsible for mass transport.

\subsubsection{References}

1. N. Q. Minh, "High-Temperature Fuel Cells, Part 2: The Solid Oxide Cell," Chemtech, February 1991, pp. 120-126.

2. L. A. Chick, J. L. Bates, and G. D. Maupin, "Air-Sintering Mechanisms of Chromites," in preparation.

3. M. A. Janney, C. L. Calhoun, and H. D. Kimrey, "Microwave Sintering of Solid Oxide Fuel Cell Materials, I: Zirconia - $8 \mathrm{~mol} \%$ Yttria," submitted to the J. Am. Ceram. Soc.

4. M. A. Janney and H. D. Kimrey, "Diffusion-Controlled Processes in MicrowaveFired Oxide Ceramics," in Microwave Processing of Materials II, MRS Symp. Proc., Vol. 189, W. B. Snyder, W. H. Sutton, D. L. Johnson, and M. F. Iskander, eds., Materials Research Society, Pittsburgh, 1990.

5. M. A. Janney, H. D. Kimrey, M. A. Schmidt, and J. O. Kiggans, "Grain Growth in Microwave-Annealed Alumina," J. Am. Ceram. Soc., in press.

6. Y. L. Tian, D. L. Johnson, and M. E. Brodwin, "Ultrafine Microstructure of $\mathrm{Al}_{2} \mathrm{O}_{3}$ Produced by Microwave Sintering," Ceramic Powder Science, II, pp. 925-32, G. L. Messing, E. R. Fuller, and H. Hausner, eds., American Ceramic Society, Westerville, Ohio, 1988.

7. C. E. Holcombe and N. L. Dykes, "Importance of 'Casketing' for Microwave Sintering of Materials," J. Matl. Sci. Lett., 9, 425-28 (1990).

8. N. Q. Minh, C. R. Horne, F. Liu, P. R. Strazak, T. L. Stillwagon, and J. J. Van Akerman, in Proceedings of the First International Symposium on Solid Oxide Fuel Cells, C. S. Singhal, ed., The Electrochemical Society: Pennington, N.J., 1989, p. 307.

9. W. W. Ho, "High-Temperature Dielectric Properties of Polycrystalline Ceramics," MRS Symp. Proc., Vol. 124, pp. 137-48, W. H. Sutton, M. H. Brooks, and I. J. Chabinsky, eds., Materials Research Society, Pittsburgh, 1988. 
10. R. W. Vest and J. M. Honig, "Highly Conducting Ceramics and the ConductorInsulator Transition," pp. 343-453 in Electrical Conductivity in Ceramics and Glass, Part B, ed. N. M. Tallan, Marcel Dekker, Inc., 1974.

\subsection{ALLOY DEVELOPMENT}

\subsubsection{Environmental Effects on Iron Aluminides - J. H. DeVan}

Alloys based on the $\mathrm{Fe}_{3} \mathrm{Al}$ system are under development at Oak Ridge National Laboratory (ORNL) in support of coal conversion and combustion materials requirements. Of particular interest is the performance of these alloys in coal gasifiers involving product gases with relatively low oxygen activities $\left(<10^{-20} \mathrm{~atm}\right)$ and high sulfur activities $\left(>10^{-8} \mathrm{~atm}\right)$.

Using $\mathrm{H}_{2} \mathrm{~S}-\mathrm{H}_{2}-\mathrm{H}_{2} \mathrm{O}$ gas mixtures, several experimental iron-aluminum alloys have been tested to assess the effects of aluminum concentration on corrosion bchavior at 700 to $800^{\circ} \mathrm{C}$ in a simulated gasifier environment. Included in these studies are alloys that have been aluminized to convert the outer surfaces to $\mathrm{FeAl}(50$ at. \% $\mathrm{Al})$. Thermogravimetric analyses, together with metallographic and chemical analyses of the corrosion product scales, are performed to determine the role of constituent metallic elements on oxidation and sulfidation processes. Additionally, the corrosion resistance of $\mathrm{Fe}_{3} \mathrm{Al}$ alloys is being evaluated by exposures at 600 to $900^{\circ} \mathrm{C}$ in the gas-cooler section of an operating gasifier in the United Kingdom.

The nature of protective scales formed on $\mathrm{Fe}_{3} \mathrm{Al}$-based alloys in sulfur-containing atmospheres, as compared to air, is being evaluated using secondary ion mass spectroscopy (SIMS) and transmission electron microscopy (TEM). Marker experiments using ${ }^{18}(0$ are conducted in conjunction with the SIMS studies to monitor oxide growth processes.

A common requirement exists for corrosion-resistant alloys for heat exchangers and heat recovery systems in coal combustion and conversion plants. Because the operating environments contain sulfur, chlorine, and carbon, as well as oxygen, alloys are subject to severe corrosion. At higher temperatures where corrosion resistance depends on the growth and integrity of protective oxide scales, sulfur has been found to accelerate oxidation kinetics and promote scale spalling. At lower temperatures the formation of sulfur-and chlorine-containing acids can lead to stress-assisted cracking as well as general wastage.

The purpose of this investigation is to evaluate the corrosion properties of $\mathrm{Fe}_{3} \mathrm{Al}$-based alloys as they relate to fossil energy applications. Corrosion evaluations of the alloys are being conducted in mixed-oxidant (oxygen-sulfur-chlorine) environments for variable times at 500 to 
$800^{\circ} \mathrm{C}$, and the results are compared with companion experiments in single-oxidant (oxygen) environments. The experiments are designed to reveal the effects of sulfur and chlorine on oxide scale growth and integrity. The microstructures, grain sizes, and impurity distribution in the oxide are analyzed by X-ray diffraction (XRD), energy dispersive X-ray spectroscopy (EDS), Auger electron microscopy (AEM), and scanning electron microscopy (SEM) [for both transverse sections and longitudinal sections of oxides]. The corrosion mechanisms and the nucleation and growth of oxides and sulfides are characterized by thermogravimetric analysis (TGA), transmission electron microscopy (TEM), and secondary ion mass spectroscopy (SIMS). The latter technique is used in combination with ${ }^{18} 0$ labeling to determine the transport mechanisms controlling oxide growth and the effects of sulfur on these mechanisms.

Oxidation-sulfidation behavior of $\mathrm{Fe}_{3} \mathrm{Al}$-based alloys is also being evaluated under actual service conditions in operating gasifiers. ${ }^{1}$ Test results for specimens exposed in the product stream of a gasifier in the United Kingdom are compared directly with results from laboratory tests at equivalent temperatures and sulfur/oxygen activities.

\subsubsection{Microscopic Studies of Reaction Product Scales}

As noted last reporting period, ${ }^{1}$ we have been studying the nature and growth patterns of corrosion product scales formed on $\mathrm{Fe}_{3} \mathrm{Al}$-based alloys in $\mathrm{H}_{2} \mathrm{~S}-\mathrm{H}_{2}-\mathrm{H}_{2} \mathrm{O}$ atmospheres at 700 to $800^{\circ} \mathrm{C}$. Energy-dispersive X-ray analyses have shown the scales to be composed principally of aluminum with negligible amounts of iron or sulfur. (Oxygen could not be analyzed by the spectrometer used.) TEM results further indicate that the scales are extremely fine grained, with the grains being randomly oriented.

An additional approach being used to evaluate processes controlling film growth involves the use of SIMS coupled with an ${ }^{18} 0$ tracer. Specimens of Fe-28\% Al (FA61) and $\mathrm{Fe}-28 \% \mathrm{Al}-2 \% \mathrm{Cr}$ (FAS) were oxidized in air for $168 \mathrm{~h}$ at $800^{\circ} \mathrm{C}$ and then were sent to Harwell Laboratory for a similar exposure in oxygen enriched with the mass $18\left({ }^{18} 0\right)$ isotope at $0.2 \mathrm{~atm}$ (also at $800^{\circ} \mathrm{C}$ ). Following the latter treatment, one edge of each specimen was metallographically polished at a $15^{\circ}$ angle of coincidence with a principal oxidized surface, thereby producing a shallow-taper cut through the oxide scale. The specimens were then returned to ORNL for analysis of the ${ }^{18} 0$ distribution in the oxide scale.

The weight changes recorded after the various oxidation treatments are listed in Table 2.2-1. The total weight gains $\left(0.05-0.13 \mathrm{mg} / \mathrm{cm}^{2}\right)$ translate to an average scale thickness of from 0.1 to $0.35 \mu \mathrm{m}$, assuming the oxide to be predominantly $\gamma-\mathrm{Al}_{2} \mathrm{O}_{3}$. The scales were first 
Table 2.2-1. Weight changes of $\mathrm{Fe}_{3} \mathrm{Al}$ alloys used for ${ }^{18} \mathrm{O}$ marker experiments

\begin{tabular}{|c|c|c|c|c|}
\hline \multirow{3}{*}{$\begin{array}{l}\text { Oxidation } \\
\text { treatment }\end{array}$} & \multicolumn{4}{|c|}{ Weight change $\left(\mathrm{mg} / \mathrm{cm}^{2}\right)$} \\
\hline & \multicolumn{2}{|c|}{$\mathrm{Fe}-28 z$} & \multicolumn{2}{|c|}{$\mathrm{Fe}-288$} \\
\hline & No. 1 & No. 2 & No. 1 & No. 2 \\
\hline $\begin{array}{l}168 \mathrm{~h} \text { in air } \\
\text { at } 800^{\circ} \mathrm{C}\end{array}$ & +0.04 & +0.04 & +0.08 & +0.00 \\
\hline $\begin{array}{l}168 \mathrm{~h} \text { in }{ }^{18} \mathrm{O} /{ }^{16} \mathrm{O} \\
\text { at } 800^{\circ} \mathrm{C}\end{array}$ & +0.01 & +0.01 & +0.05 & +0.06 \\
\hline Combined & 0.05 & 0.05 & 0.13 & 0.06 \\
\hline
\end{tabular}

analyzed by depth profiling (ablation) using gallium ions incident at a right angle with the oxidized surface. The relative intensities of ${ }^{18} 0^{-}$to ${ }^{16} 0^{-}$ions at varying depths through the scale were recorded by a mass spectrometer, and a profile of the two isotopes is shown in Fig. 2.2-1. The ${ }^{18} \mathrm{O}$ peak near the oxide/gas interface is evidence for oxide growth occurring at the gas side of the scale (i.e., growth controlled by cation diffusion). However, the oxygen concentrations (particularly that of ${ }^{16} 0^{-}$at the scale/metal interface) do not decrease as rapidly as would be expected assuming a uniform oxide thickness. In fact, scanning electron images of the scale showed a very noruniform scale thickness, with the thickest cross sections developing at surface imperfections induced by the 600 -grit abrasive paper that was used to prepare the original surface. Thus, even within the smallest area of oxide that could be demarked for analysis, ablation of the oxide down to the underlying metal occurred relatively early in some sections and much later in others, with the result that oxygen fluxes diminished in multiple steps rather than all at once. The scratches left by the initial surface preparation also interfered with the examination of the taper cut through the oxide. The oxide appeared to grow preferentially on the peaks and valleys of the scratches, so that the taper cross section sliced through localized pockets of oxide that were too isolated and small to analyze effectively.

Despite the problems with surface roughness, the present results do lend strong support to the supposition ${ }^{2}$ that oxide growth on alumina formers at lower temperatures is 
ORNL-DWG 90-10249

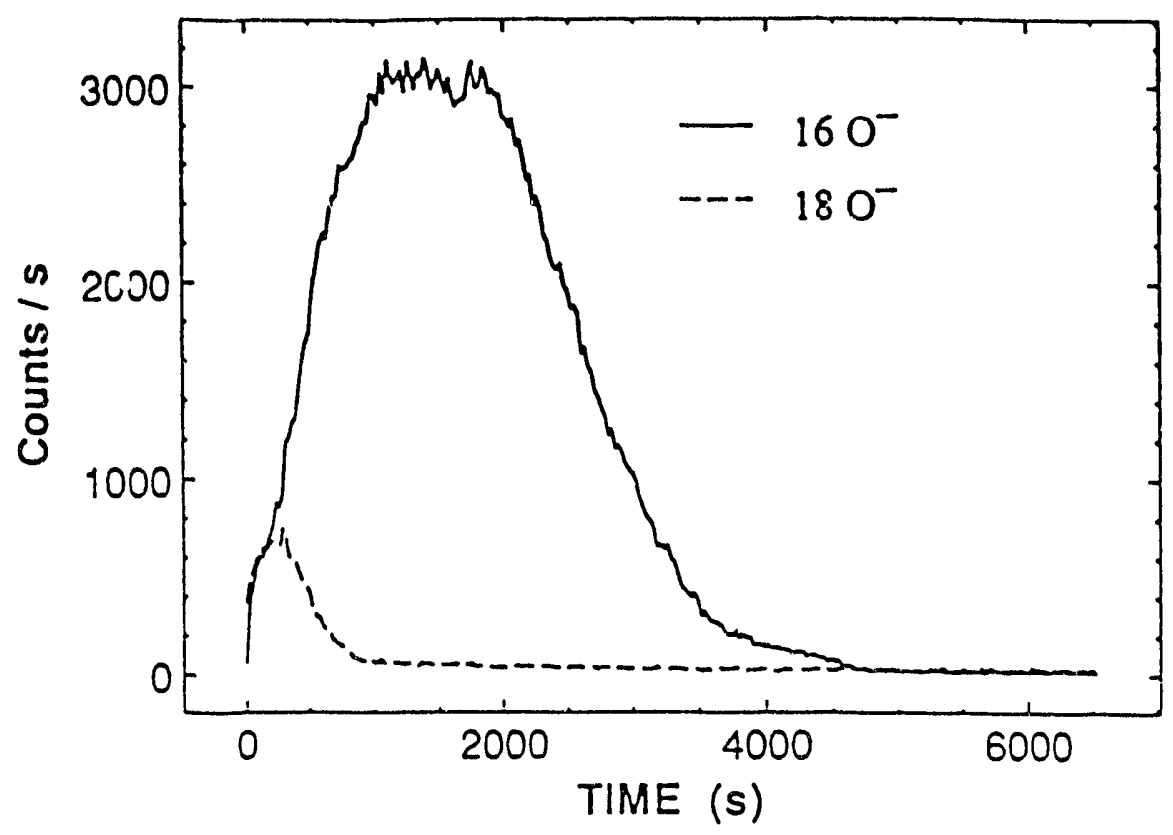

Fig. 2.2-1. Depth profile of oxide film formed on $\mathrm{Fe}-28 \% \mathrm{Al}-2 \% \mathrm{Cr}$ at $800^{\circ} \mathrm{C}$ showing relative ${ }^{18} \mathrm{O}$ and ${ }^{16} \mathrm{O}$ concentrations determined by secondary ion mass spectroscopy. Depth below the original external oxide surface is proportional to sputtering time (denoted by the $\mathrm{X}$-axis).

controlled by cation movement. The results also indicate the importance of surface finish on the initiation and growth of oxides on iron aluminides. Accordingly, further marker experiments are planned with both chemically and mechanically polished surfaces to compare their oxidation rates and morphologies with those of the present samples.

\subsubsection{Exposures to Mixed Gases}

Recent corrosion evaluations in $\mathrm{H}_{2} \mathrm{~S}-\mathrm{H}_{2}-\mathrm{H}_{2} \mathrm{O}$ mixed gases have involved two specific test objectives: (1) effects of $\mathrm{HCl}$ as an additional gas component, and (2) effects of aluminized coatings on $\mathrm{Fe} 28 \% \mathrm{Al}-5 \% \mathrm{Cr}$ alloys. Test equipment has been modified to permit the incorporation of $\mathrm{HCl}$ at concentrations of 500 to $10,000 \mathrm{ppm}$ (by volume) in our $\mathrm{H}_{2} \mathrm{~S}-\mathrm{H}_{2}-\mathrm{H}_{2} \mathrm{O}$ mixed gas. The method presently used to add $\mathrm{H}_{2} \mathrm{O}$ to the mixed gas (i.e., bubbling a $\mathrm{H}_{2} \mathrm{~S}-\mathrm{H}_{2}$ gas mixture through a water bath at controlled temperature) has been modified to allow the simultaneous addition of $\mathrm{H}_{2} \mathrm{~S}$ and $\mathrm{HC}$. By controlling both the concentration of $\mathrm{HCl}$ in the water bath and the bath temperature, a fixed concentration of $\mathrm{H}_{2} \mathrm{O}(1.7 \mathrm{vol} \%)$ and a variable concentration of $\mathrm{HCl}(500-10,000 \mathrm{ppm})$ can be added to the $\mathrm{H}_{2} \mathrm{~S}-\mathrm{H}_{2}$ gas mixture. 
Other modifications of our test apparatus have involved changes in our gas supply lines, including the replacement of stainless steel parts with teflon. Based on laboratory screening tests in $\mathrm{H}_{2} \mathrm{~S}-\mathrm{H}_{2}-\mathrm{H}_{2} \mathrm{O}$ gas mixtures at 700 to $800^{\circ} \mathrm{C}$, binary $\mathrm{Fe}_{3} \mathrm{Al}$ alloys (nominally $28 \% \mathrm{Al}$ ) are equivalent in corrosion resistance to $\mathrm{FeAl}$ alloys containing still higher aluminum levels $(<40 \%)$. However, the higher aluminum levels do provide an improvement in corrosion resistance when chromium additions are made to the respective alloys. This effect is illustrated in Fig. 2.2-2, which compares the weight changes of a $40 \%$ Al alloy containing $4 \% \mathrm{Cr}$ with a $28 \% \mathrm{Al}$ alloy containing $4 \% \mathrm{Cr}$. The corrosion rate of the higher $\mathrm{Al}$ alloy shows no change in $\mathrm{H}_{2} \mathrm{~S}-\mathrm{H}_{2}-\mathrm{H}_{2} \mathrm{O}$ at $800^{\circ} \mathrm{C}$ compared to $\mathrm{Fe}-28 \% \mathrm{Al}$, while the rate of $\mathrm{Fe}-28 \% \mathrm{Al}-4 \% \mathrm{Cr}$ is considerably greater than that of binary Fe-28\% Al. To avoid the loss in corrosion resistance associated with chromium, we have recommended that $\mathrm{Fe}_{3} \mathrm{Al}$ alloys marked specifically for service in low $\mathrm{P}_{02}$-high $\mathrm{pS}_{2}$ mixed gas environments (e.g., gasifiers) should be limited to chromium concentrations of $<2 \%$. For applications under more oxidizing conditions, however, such as combustion atmospheres, $\mathrm{Fe}_{3} \mathrm{Al}$ alloys containing up to $5 \% \mathrm{Cr}$ have generally afforded better corrosion resistance than the $2 \% \mathrm{Cr}$ alloy. ${ }^{3}$

To meet both the lower and higher $\mathrm{P}_{02}$ requirements in a single material, we are evaluating the possibility of increasing the aluminum concentration at the exposed surfaces of chromium-containing $\mathrm{Fe}_{3} \mathrm{Al}$ alloys, so as to emulate the corrosion behavior of $\mathrm{FeAl}$ alloys containing $40 \% \mathrm{Al}$. Surface treatment of the $\mathrm{Fe}_{3} \mathrm{Al}$ alloys is being done at Ohio State University (OSU) as part of the chromizing/aluminizing development effort supported by the Fossil Energy Advanced Research and Technology Development Material Program. Specimens of a geometry suitable for weight change studies are provided to OSU for treating by their developmental pack-aluminizing process. Aluminum activities are controlled to promote the growth of an Fe $\mathrm{Al}$ surface zone with a corresponding aluminum concentration no greater than $50 \%$, thus ensuring that there is no phase transformation accompanying the aluminizing process. ( $\mathrm{Fe}_{3} \mathrm{Al}$ and $\mathrm{FeAl}$ have identical crystal structures at the aluminizing temperature.) Microstructures of $\mathrm{Fe}_{3} \mathrm{Al}$ alloys created by the $\mathrm{OSU}$ process typically show a uniform FeAl layer growing outward from the original surface, controlled by outward diffusion of iron, and a subsurface zone of FeAl contiguous with this outer layer, which forms by inward diffusion of $\mathrm{Al}$. The combined thickness of the inner and outer FeAl zones ranges from 47 to 147 microns, depending on the process time and temperature. Corrosion tests of two FA-129 (Fe-28\% Al-5\% Cr-0.5\% Nb-0.2\% C) specimens treated by this pack-aluminizing process 


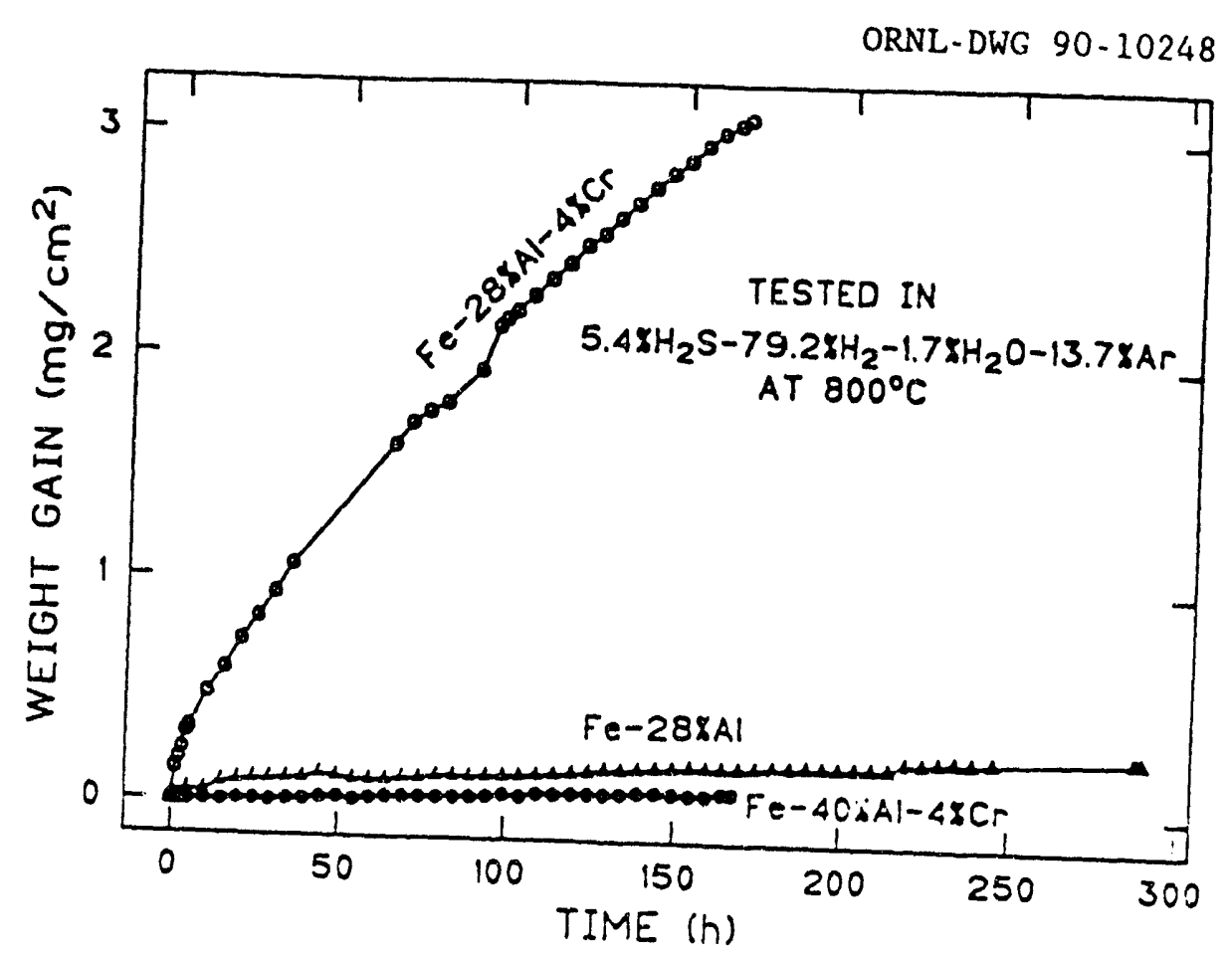

Fig. 2.2-2. Comparison of weight changes of $\mathrm{Fe}_{3} \mathrm{Al}$ and $\mathrm{FeAl}$ alloys containing $4 \% \mathrm{Cr}$ with $\mathrm{Fe}-28 \% \mathrm{Al}$. Alloys were exposed to $\mathrm{H}_{2} \mathrm{~S}-\mathrm{H}_{2}-\mathrm{H}_{2} \mathrm{O}$
gas mixture at $800{ }^{\circ} \mathrm{C}$.

(OSU-3 and OSU-5) were recently conducted for $168 \mathrm{~h}$ in $5.4 \% \mathrm{H}_{2} \mathrm{~S}-79.2 \% \mathrm{H}_{2}-1.7 \% \mathrm{H}_{2} \mathrm{O}$ $13.7 \% \mathrm{Ar}(\mathrm{vol} \%)$ at $800^{\circ} \mathrm{C}$, and the weight change results are compared with those of an untreated specimen in Fig. 2.2-3. The aluminizing treatment obviously enhanced the corrosion resistance of both specimens, in agreement with the effect of increasing aluminum concentration from 28 to $40 \%$ in iron aluminides containing $5 \%$ chromium (Fig. 2.2-2). The small difference in weight change between the two aluminized specimens may be attributable to a difference in the respective aluminizing treatments. Although the times and temperatures of the treatments were held constant, the specimen with the higher weight change in the mixed gas (OSU -5) was treated in a bed that incorporated boron as well as aluminum as a diffusing species. The total mass increase incurred during the latter treatment $\left(8.0 \mathrm{mg} / \mathrm{cm}^{2}\right)$ was slightly less than that incurred in the bed without boron $\left(9.7 \mathrm{mg} / \mathrm{cm}^{2}\right)$. Thus, the higher corrosion rate of OSU.5 may be associated either with a slightly thinner aluminized layer or with the presence of boron in the surface layer. 
ORNL-DWG 90-10247

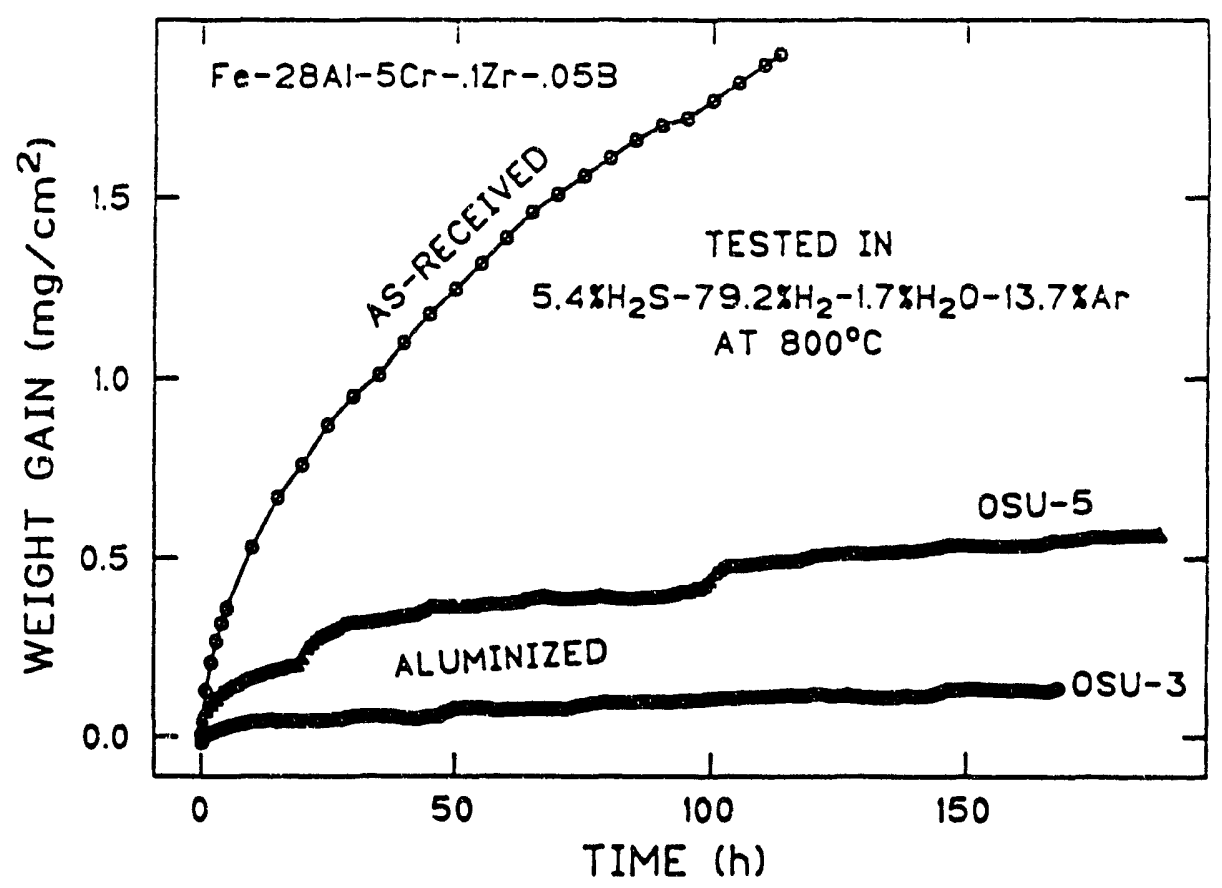

Fig. 2.2-3. Eifect of aluminizing surface treatment on corrosion rate of $\mathrm{Fe}-28 \% \mathrm{Al}-5 \% \mathrm{Cr}-. / 1 \% \mathrm{Zr}-.05 \% \mathrm{~B}$ alloy in $\mathrm{H}_{2} \mathrm{~S}-\mathrm{H}_{2}-\mathrm{H}_{2} \mathrm{O}$ gas mixture at $800^{\circ} \mathrm{C}$.

\subsubsection{Tests in Operating Gasifiers}

Specimens of two $\mathrm{Fe}_{3} \mathrm{Al}$-based alloys have been supplied to the Coal Research Establishment (CRE) of the British Coal Corporation for testing in a pressurized coal gasifier located at Stoke Orchard in England.' This gasifier is being operated by CRE as part of a topping cycle initiative supported by an association of European companies. The concept couples a gas turbine with a pressurized coal gasifier and also incorporates either a circulating fluid bed or pressurized fluidized-bed combustor that will operate on char from the gasifier. The $\mathrm{Fe}_{3} \mathrm{Al}$ alloys are being exposed together with other candidate heat exchanger materials in the product gas immediately after it exits from the gasifier. The specimens are in the form of rings, $36 \mathrm{~mm} \mathrm{OD} \times 26 \mathrm{~mm}$ ID $\times 10-20 \mathrm{~mm}$ long, and are supported on a cornmon mandrel. Two Fe-28\% Al alloys, one containing $2 \% \mathrm{Cr}$ (FAS) and the other $5 \% \mathrm{Cr}$ (FA-129) were fabricated to the required dimensions and supplied to CRE in June 1990.

Initial operation of the plant began in February 1991, when a 250-h run was completed. The test section designated for materials cvaluation was located downstream of a tertiary cyclone where product gas temperatures were projected to be in the range 900 to 
$500^{\circ} \mathrm{C}$. However, because of unanticipated heat losses, the operating temperature of the section was determined to be in the range 650 to $450^{\circ} \mathrm{C}$. Another test section is being installed to allow testing at higher temperatures and will be located downstream of the primary cyclone. During the initial commissioning period, only two of the $\mathrm{Fe}_{3} \mathrm{Al}$ specimens were exposed in gasifier gas, and the exposure temperature was limited to $550^{\circ} \mathrm{C}$. No results are yet available from sections through these samples, although visual examination indicated only a thin oxide layer. The plant is scheduled to operate for two 500-h periods over the duration of 1991 and for two additional 500-h periods in 1992. $\mathrm{Fe}_{3} \mathrm{Al}$ specimens will be included in each of these runs. Results of visual and metallographic examinations will be reported by CRE as they become available.

Preliminary oxidation tests using an oxygen isotope $\left({ }^{18} 0\right)$ marker were conducted to establish the growth mechanism of alumina scales on $\mathrm{Fe}_{3} \mathrm{Al}$-based alloys at $800^{\circ} \mathrm{C}$. Scales grown initially in air and then in oxygen enriched in ${ }^{18} 0$ were depth profiled using SIMS. Concentrated ${ }^{18} 0$ at the outermost surface of the scale indicated that scale growth was most likely controlled by the outward movement of aluminum through the scale.

The thickness of the oxide, as determined by SIMS analysis of the above specimens, was found to vary as a result of the surface roughness introduced by mechanical abrasion prior to the oxidation exposures. This effect, which resulted in a more gradual apparent decrease in the ${ }^{18} 0$ gradient than actually existed, emphasizes the importance of surface finish on scale morphology.

The effects of surface treating $\mathrm{Fe}_{3} \mathrm{Al}$ alloys to increase the near-surface aluminum content are being studied in a $\mathrm{H}_{2} \mathrm{~S}-\mathrm{H}_{2}-\mathrm{H}_{2} \mathrm{O}$ gas mixture at $800^{\circ} \mathrm{C}$. An alloy containing $28 \% \mathrm{Al}$ and $5 \% \mathrm{Cr}$ was aluminized at Ohio State University to convert the outer surfaces to FeAl. The corrosion rate over a 168 -h period was significantly reduced by the aluminizing treatment, the rate being commensurate with that of a FeAl-based alloy containing $40 \% \mathrm{Al}$ and $4 \% \mathrm{Cr}$.

Two Fe-28\% Al alloys, containing $2 \%$ and $5 \% \mathrm{Cr}$ respectively, have been supplied to the Coal Research Establishment of the British Coal Corporation for testing in the product gas stream of an operating gasifier. Testing to date has been limited by variable operating conditions during plant commissioning; however, an initial exposure at $550^{\circ} \mathrm{C}$ showed no evidence of attack beyond a thin oxide film. Additional 500-h tests are scheduled for the remainder of 1991 through 1992 and will provide evaluations of the $\mathrm{Fe}_{3} \mathrm{Al}$ alloys at temperatures up to $900^{\circ} \mathrm{C}$. 


\subsubsection{References}

1. J. H. DeVan, "Environmental Effects on Iron Aluminides," pp. 353-56 in AR\&TD Fossil Energy Materials Program Semiannual Progress Report for Period Ending September 30, 1990, ORNL/FMP-90/2, Martin Marietta Energy Systems, Inc., Oak Ridge National Laboratory, December 1990.

2. E. W. A. Young, H. E. Bishop, and J. W. H. de Wit, "On the Use of Markers and Tracers to Establish the Growth Mechanism of Alumina Scales During High Temperature Oxidation," Surface and -Interface Analysis 9, 163 (1986).

3. S. Van Weele and J. L. Blough, "Fireside Corrosion Testing of Candidate Superheater Tube Alloys, Coatings, and Cladding," in Proceedings of the Fifth Annual Fossil Energy Conference, Oak Ridge, TN, Session IIA.

4. F. D. Geib, M. A. Harper, and R. A. Rapp, "Fundamental Study of Aluminizing and Chromizing Processes" in Proceedings of the Fifth Annual Fossil Energy Conference, Oak Ridge, TN, Session IIA.

\subsubsection{Investigation of Austenitic Alloys for Advanced Heat Recovery and Hot-Gas Cleanup Systems - R. W. Swindeman}

Evaluation of commercial and developmental austenitic alloys for advanced heat recovery and hot-gas cleanup systems was directed toward the completion of studies of lean stainless steels and continuation of research on filler metals and higher chromium austenitic alloys for more demanding service conditions. Testing of lean stainless steels under long-time creep $(45,000 \mathrm{~h})$ confirmed the expectations that the alloys could meet the target mechanical performance requirements for strength (100 MPa average rupture strength at $700^{\circ} \mathrm{C}$ and $100,000 \mathrm{~h}$ ) and ductility (5\% rupture strain at 100,000 h). Testing of weldments made with CRE 16-8-2 stainless steel and alloy 556 was extended to beyond 10,000 h. Testing of $20 \mathrm{Cr}-30 \mathrm{Ni}-2 \mathrm{Mo}-\mathrm{Fe}$ alloys reached times beyond 30,000 h. Alloys containing small levels of nitrogen exhibited good strength, and even a vacuum-melted low-nitrogen alloy was stronger than alloy $800 \mathrm{H}$. Research was started to examine alloys for hot-gas cleanup systems at temperatures around $850^{\circ} \mathrm{C}$.

The purpose of this activity is to evaluate advanced austenitic alloys for the design, construction, and reliable operation of advanced heat recovery systems and hot-gas cleanup systems. ${ }^{1}$ Due to limitations in the high-temperature strength and corrosion resistance of ironbase alloys and the high cost of nickel-base superalloys, most fossil power plants produce steam at temperatures around $550^{\circ} \mathrm{C}$ and pressures near $32 \mathrm{MPa}$. However, advances in materials science relating composition and microstructure of steels to their high-temperature 
mechanical properties and stability have made it possible to develop austenitic alloys with significantly improved strength and ductility. Similar advances in the development of coating and cladding techniques of these high-strength alloys provide an opportunity to improve the reliability in regard to corrosion protection.

\subsubsection{Long-Time Testing of Lean Stainless Stecls}

The lean stainless steels are those that contain less than $20 \%$ chromium, and types 304 , 316,321 , and 347 stainless steels are examples. However, to meet the requirements for tubing in an advanced boiler, it was expected that a candidate alloy would need to possess nearly twice the creep strength of the best of the commercial 300 series austenitic stainless steels. ${ }^{2}$ To accomplish this, MC-forming elements such as titanium, niobium, and vanadium were added to a $14 \% \mathrm{Cr}-16 \% \mathrm{Ni}-2 \% \mathrm{Mo}-\mathrm{Fe}$ base composition. New materials developed at ORNL are identified as HT-UPS (high-temperature ultrafine-precipitation strengthened) steels by Maziasz $z^{3}$ and a recent report provided a detailed evaluation and assessment of the potential of these alloys. ${ }^{4}$ More than fourteen alloys were produced and some typical chemistries are listed in Table 2.2-2.

Most of the research on the lean stainless steels has been completed, but a few longtime tests are continuing. Figure 2.2-4 shows the trend for the creep of the hot-rolled, copper-bearing CE3 alloy under low-stress creep conditions. The test at $100 \mathrm{MPa}$ maintained a

Table 2.2-2. Chemical compositions of several lean stainless steels (wt \%)

\begin{tabular}{ccccc}
\hline E1ement & 316SS & CE3 & AX5 & BWT4 \\
\hline C & 0.057 & 0.086 & 0.076 & 0.088 \\
Si & 0.58 & 0.21 & 0.12 & 0.10 \\
Mn & 1.86 & 1.75 & 2.04 & 1.79 \\
$\mathrm{Ni}$ & 13.5 & 16.2 & 16.2 & 15.04 \\
$\mathrm{Cr}$ & 17.2 & 14.5 & 13.9 & 13.7 \\
$\mathrm{Ti}$ & 0.02 & 0.27 & 0.27 & 0.10 \\
$\mathrm{Nb}$ & 0.12 & 0.15 & 0.17 & \\
$\mathrm{~V}$ & 0.56 & 0.52 & 0.44 & \\
$\mathrm{Mo}$ & 2.34 & 2.41 & 2.46 & 2.19 \\
$\mathrm{P}$ & 0.024 & 0.071 & 0.024 & 0.016 \\
$\mathrm{~B}$ & 0.005 & 0.005 & 0.004 & \\
$\mathrm{~N}$ & 0.030 & 0.012 & 0.021 & 0.008 \\
$\mathrm{Cu}$ & 0.10 & 1.96 & & \\
\hline
\end{tabular}


ORNL-DWG $91-9712$

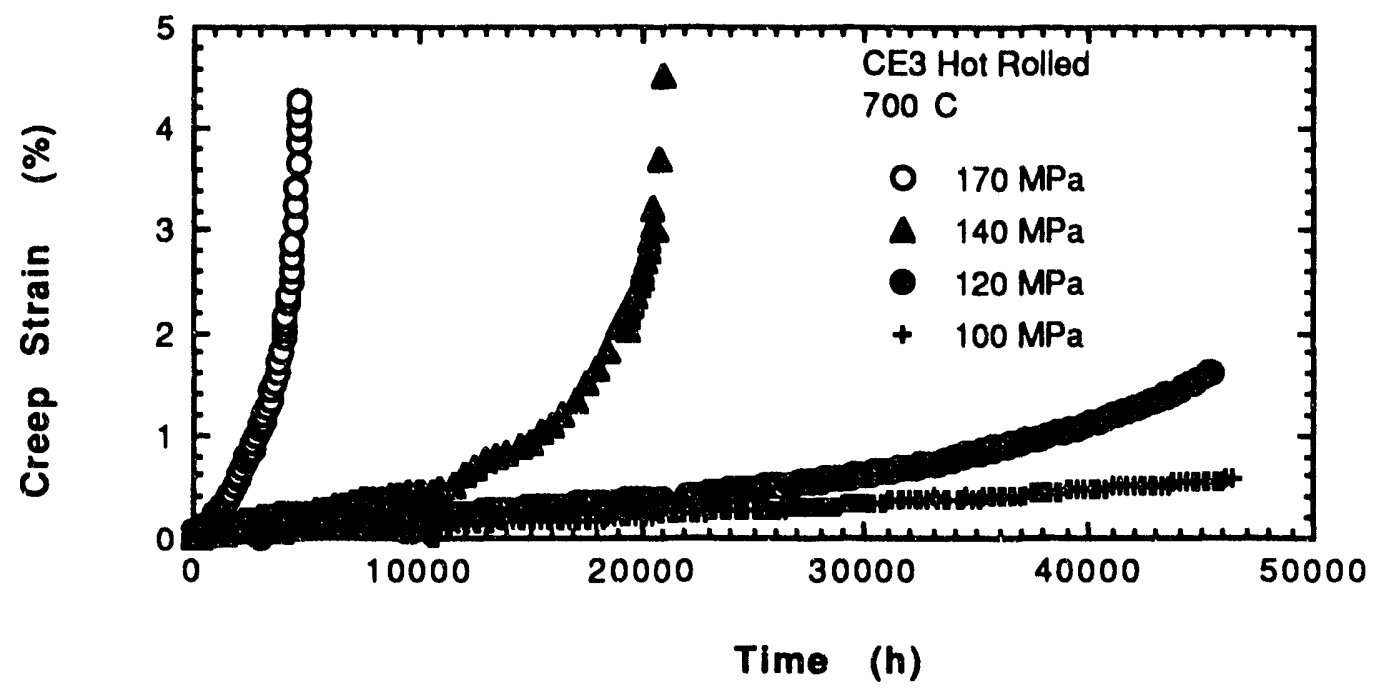

Fig. 2.2-4. Long-time creep curves for hot-rolled CE3 tested at $700^{\circ} \mathrm{C}$.

steady creep rate for at least $45,000 \mathrm{~h}$. Data indicate that the CE3 heat would exceed the target rupture strength of $100 \mathrm{MPa}$ at $700^{\circ} \mathrm{C}$ and $100,000 \mathrm{~h}$. Tests on cold-rolled plate (AX series alloys) have indicated higher strengths than those seen in hot-rolled CE3 material. Typical long time test data have been plotted in Fig. 2.2-5. Here, it may be seen that alloy AX5 endured over $40,000 \mathrm{~h}$ at $700^{\circ} \mathrm{C}$ and $170 \mathrm{MPa}$ and $30,000 \mathrm{~h}$ at $600^{\circ} \mathrm{C}$ and $350 \mathrm{MPa}$. Reduction of areas was $20 \%$ or greater.

Recently, testing of specimens from BWT4 tubular product was started. Various thermal-mechanical conditions were investigated, and it was found that the optimum strength could be produced by a $5 \%$ cold reduction of annealed material. Typical creep curves for specimens from the tubing are shown in Fig. $2.2-6$ for tests at $700^{\circ} \mathrm{C}$ and $170 \mathrm{MPa}$. In the hot-extruded condition, the tubing endured $1000 \mathrm{~h}$, while in the $5 \%$ cold-sunk condition the tubing exhibited very little creep after $15,000 \mathrm{~h}$.

\subsubsection{Testing of Weldments}

The niobium-bearing, MC-forming alloys such as type 347 stainless steel have problems with regard to hot-cracking in weldments, and the lean stainless steel HT-UPS alloys also contain niobium. Further, the HT-UPS lean stainless steels have low chromium to nickel ratios and solidify with no delta ferrite ${ }^{5}$, hence, dissimilar filler metals are needed to minimize hot-cracking. Typical filler metals are Inconel $82^{\circ}$, CRE 16-8-2 stainless steel, and Haynes 


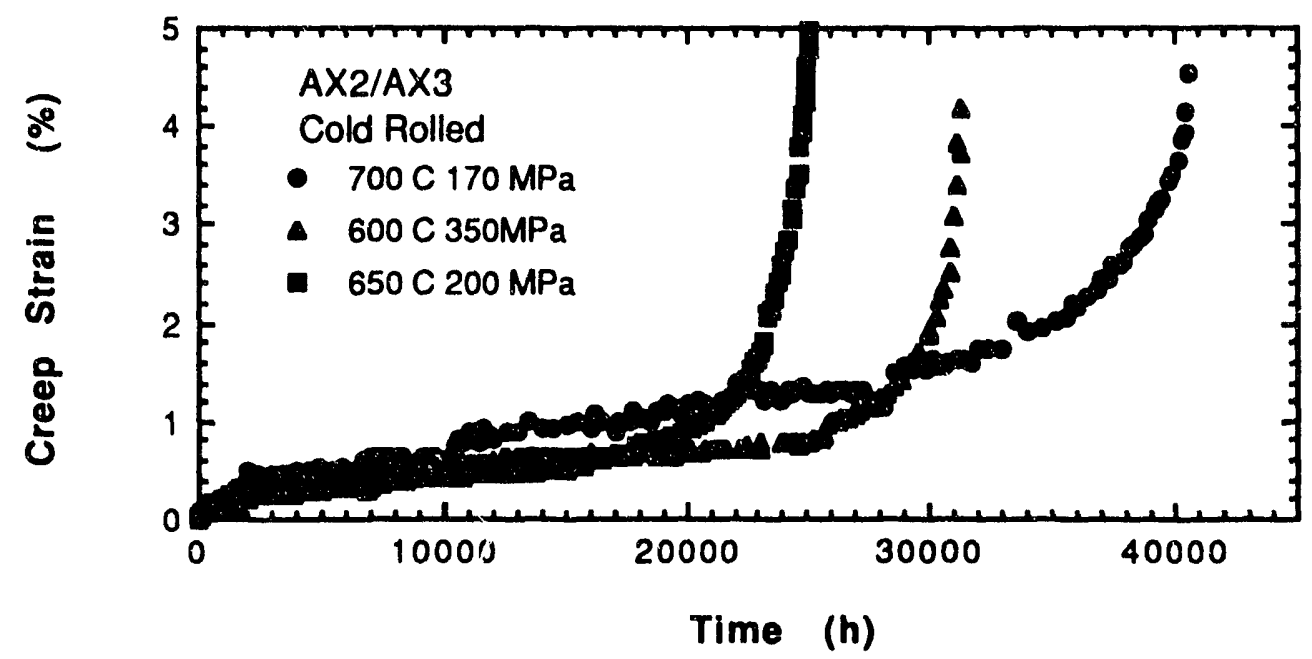

Fig. 2.2-5. Long-time creep curves for cold-rolled AX5 tested at three temperatures.

ORNL-DWG 91-9714

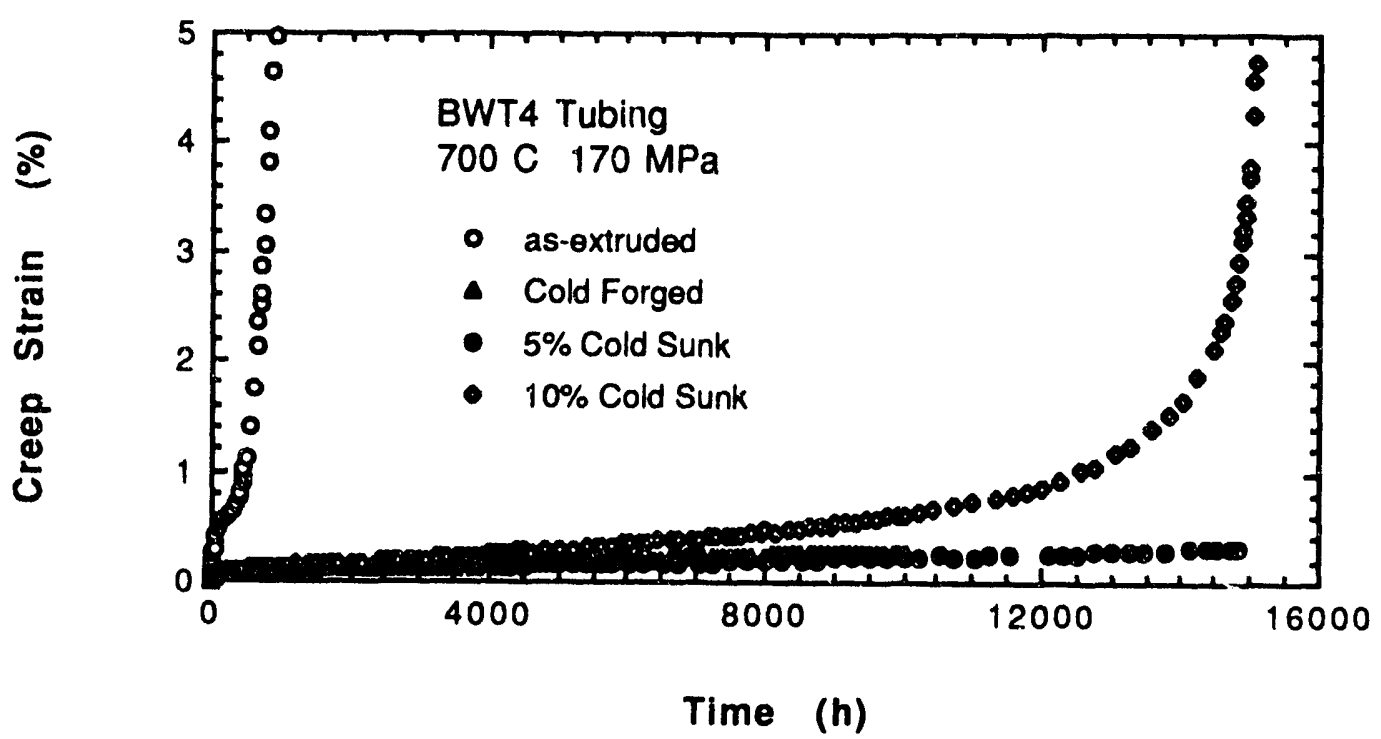

Fig. 2.2-6. Effect of cold work on the creep of BWT4 at $700^{\circ} \mathrm{C}$. 
alloy $556{ }^{4}{ }^{4}$ The 10,000 $\mathrm{h}$ rupture strengths of other filler metals are compared in Fig. 2.2-7. Included are trends for all-filler metal and weldments in which the filler metal was used to join HT-UPS alloys. Alloy 556 filler metal exhibited the best strength above $700^{\circ} \mathrm{C}$, followed by CRE 16-8-2 stainless steel. Below $650^{\circ} \mathrm{C}$ Inconel $82^{\circ}$ would be a good choice.

\subsubsection{Evaluation of Modified Alloy $800 \mathrm{H}$}

The high chromium austenitic alloys are those that contain 20 to $30 \%$ chromium, 20 to 35\% nickel, and iron. Examples are 310 stainless steel and alloy $800 \mathrm{H}$. There are many modifications to the alloys, and new alloys of particular interest to the advanced austenitic alloy evaluation activity include Sumitomo HR3C , which is a modified type 310 stainless steel $^{6}$, and Nippon Steel NF7090, which is a modified $20 \mathrm{Cr}-25 \mathrm{Ni}$ steel ${ }^{7}$. In addition, modifications to alloy $800 \mathrm{H}$ have been examined at $\mathrm{ORNL}^{8}$ and by Doi, et al. ${ }^{9}$ Compositions are identified in Table 2.2-3.

The ORNL-modified $800 \mathrm{H}$ alloys $\mathrm{AX} 2$ and $\mathrm{AX} 3$ were produced as 13 -mm thick plate, and the BWT7 alloy was produced as hot-extruded tubing. The influence of thermalmechanical processing of these HT-UPS alloys is under investigation. Small amounts of cold or warm work were found to be beneficial in improving the strength of the AX2 and AX3 alloys. This may be seen in Fig. 2.2-8 which compares the creep curves for annealed and millannealed $\left(1200^{\circ} \mathrm{C}\right.$ annealed plus $10 \%$ cold-rolled) specimens in Fig. 2.2-8a with curves for

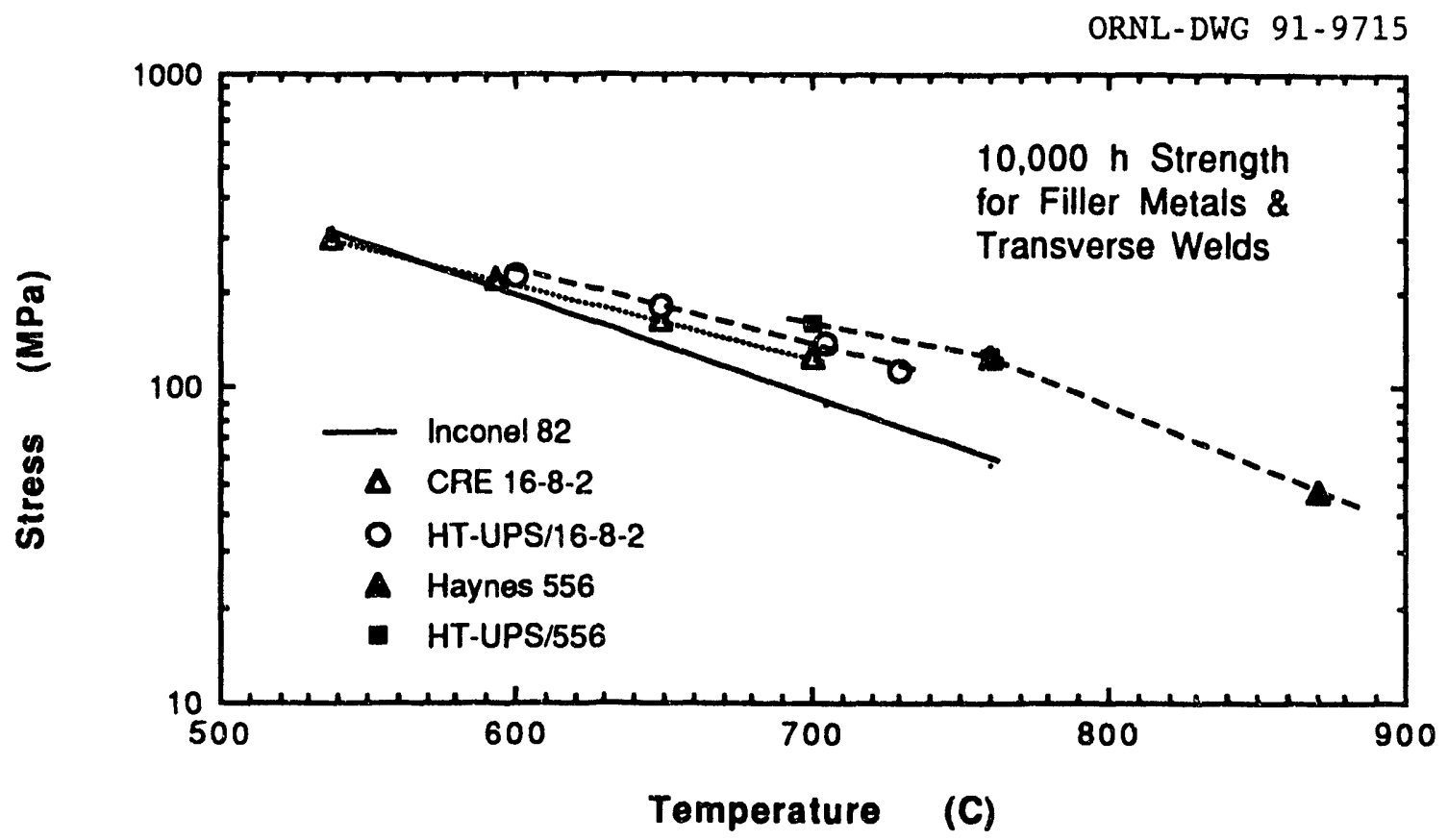

Fig. 2.2-7. Comparison of the $10,000 \mathrm{~h}$ strength of several filler metals and weldments. 
Table 2.2-3. Chemical compositions of several high chromium alloys (wt \%)

\begin{tabular}{|c|c|c|c|c|c|c|}
\hline E1. & $800 \mathrm{H}$ & $\mathrm{HR} 3 \mathrm{C}$ & NF709 & AX2 & $\mathrm{AX} 3$ & BWT7 \\
\hline C & 0.08 & 0.060 & 0.150 & 0.090 & 0.092 & 0.100 \\
\hline Si & 0.24 & 0.40 & 0.50 & 0.23 & 0.22 & 0.10 \\
\hline $\mathrm{Mn}$ & 0.90 & 1.2 & 1.0 & 1.96 & 2.0 & 2.0 \\
\hline $\mathrm{Ni}$ & 32.1 & 20.1 & 25.1 & 30.1 & 30.1 & 30.1 \\
\hline $\mathrm{Cr}$ & 20.1 & 25.1 & 20.1 & 20.1 & 21.1 & 20.1 \\
\hline $\mathrm{Ti}$ & 0.42 & & & 0.36 & 0.36 & 0.28 \\
\hline $\mathrm{Nb}$ & 0.45 & 0.20 & 0.24 & 0.24 & 0.22 & \\
\hline $\mathrm{V}$ & & & & 0.53 & 0.52 & 0.59 \\
\hline Mo & & & 1.5 & 1.96 & 2.0 & 1.89 \\
\hline$P$ & 0.02 & & & 0.045 & 0.031 & 0.020 \\
\hline B & & & 0.005 & 0.011 & 0.010 & 0.006 \\
\hline $\mathrm{N}$ & & 0.20 & 0.05 & 0.028 & 0.029 & 0.007 \\
\hline Al & 0.43 & & & & & 0.01 \\
\hline
\end{tabular}

$1200^{\circ} \mathrm{C}$ annealed specimens in Fig. 2.2-8b. The cold-rolled AX2 and AX3 materials lasted significantly longer at the test conditions of $700^{\circ} \mathrm{C}$ and $170 \mathrm{MPa}$.

Testing of the BWT7 alloy annealed at $1200^{\circ} \mathrm{C}$ is in the early stages, but some comparisons may be made with the annealed $\mathrm{AX}$ alloys and $800 \mathrm{H}$ on the basis of the stress versus the minimum creep rate. Data produced at $650^{\circ} \mathrm{C}$ have been plotted in Fig. 2.2-9. The BWT7 tubing in the $1200^{\circ} \mathrm{C}$ condition was weaker than the AX alloys but stronger than alloy $800 \mathrm{HT}$. A new lot of BWT7 tubing has been processed in the $1190^{\circ} \mathrm{C}$ and $5 \%$ cold pilgered condition. ${ }^{10}$ Testing of this material will begin soon.

\subsubsection{Alloys for Hot-Gas Cleanup Applications}

Hot-gas cleanup systems are being developed for pressurized fluidized bed combustors (PFBC). One cleanup concept involved the use of ceramic barrier filters that operate at temperatures in the range 800 to $900^{\circ} \mathrm{C}^{11}$ Metallic materials will be used to support the filters and fabricate the blowback manifold systems that are required for filter cleaning. Although the gaseous environment is oxidizing, a potential for some sulfidation exists if sulfurbearing particulates collect on metallic components in the dirty gas side of the gas stream. High oxidation resistance, fabricability, and good thermal fatigue resistance are of primary concern in the selection of the structural components, and several alloys are being investigated to establish the potential for eventual use. ${ }^{12}$ Some alloys are listed in Table 2.2-4 and include RA333 , Haynes alloy 556 ${ }^{\circ}$, Inconel $617{ }^{\circ}$, HR $160^{\circ}$, and nickel-chromium-aluminides IC221 
ORNL-DWG 91-9716

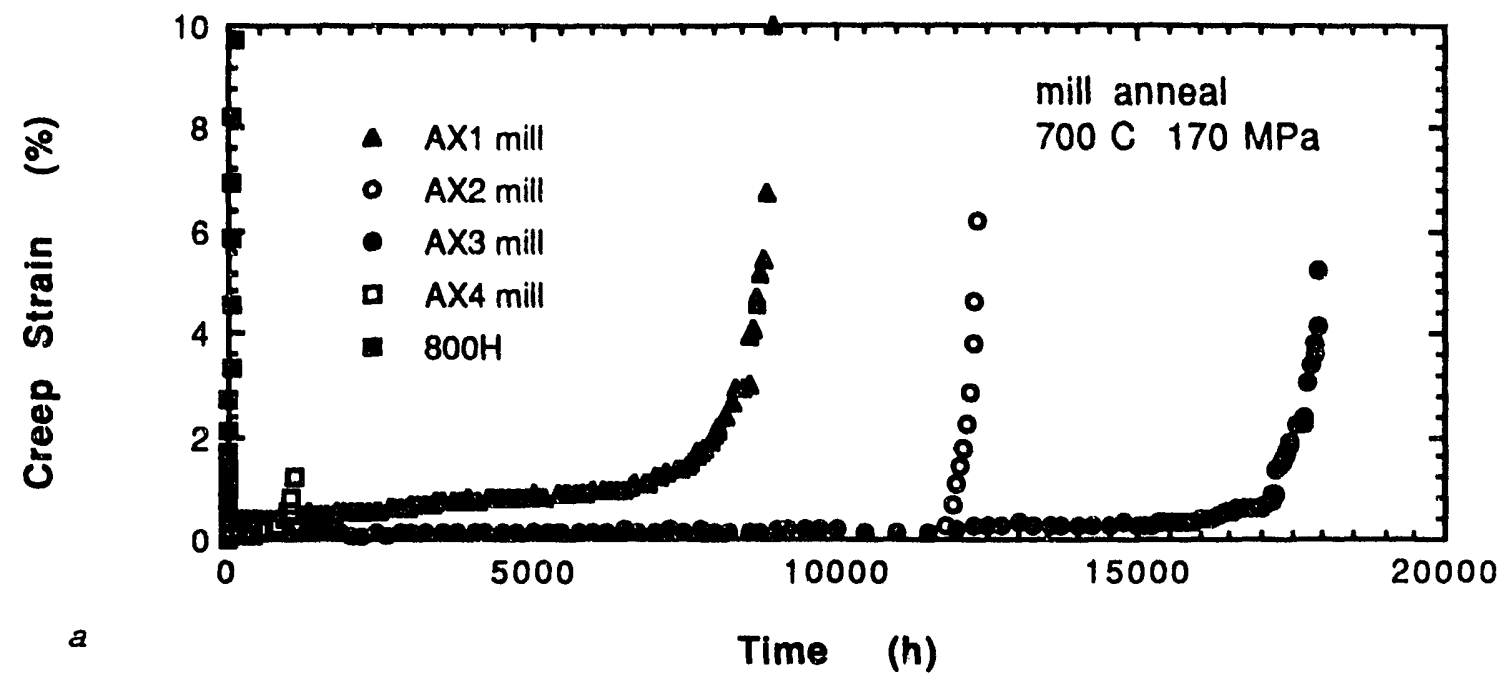

ORNL-DWG 91-9717

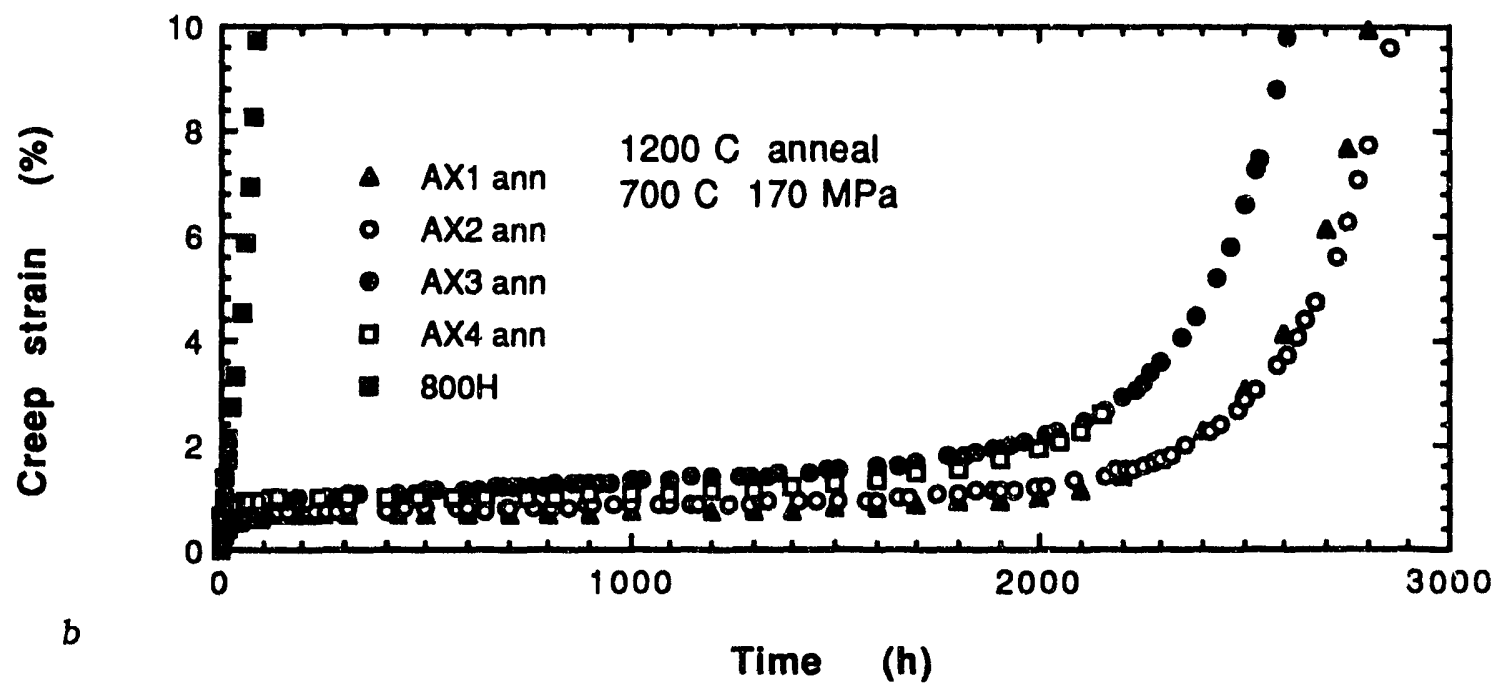

Fig. 2.2-8. Creep curves for several $20 \% \mathrm{Cr}-30 \% \mathrm{Ni}-\mathrm{Fe}$ alloys tested at $700^{\circ} \mathrm{C}$ and $170 \mathrm{MPa}$ (a) mill-annealed and (b) $1200^{\circ} \mathrm{C}$ annealed. 
ORNL-DWG 91-9718

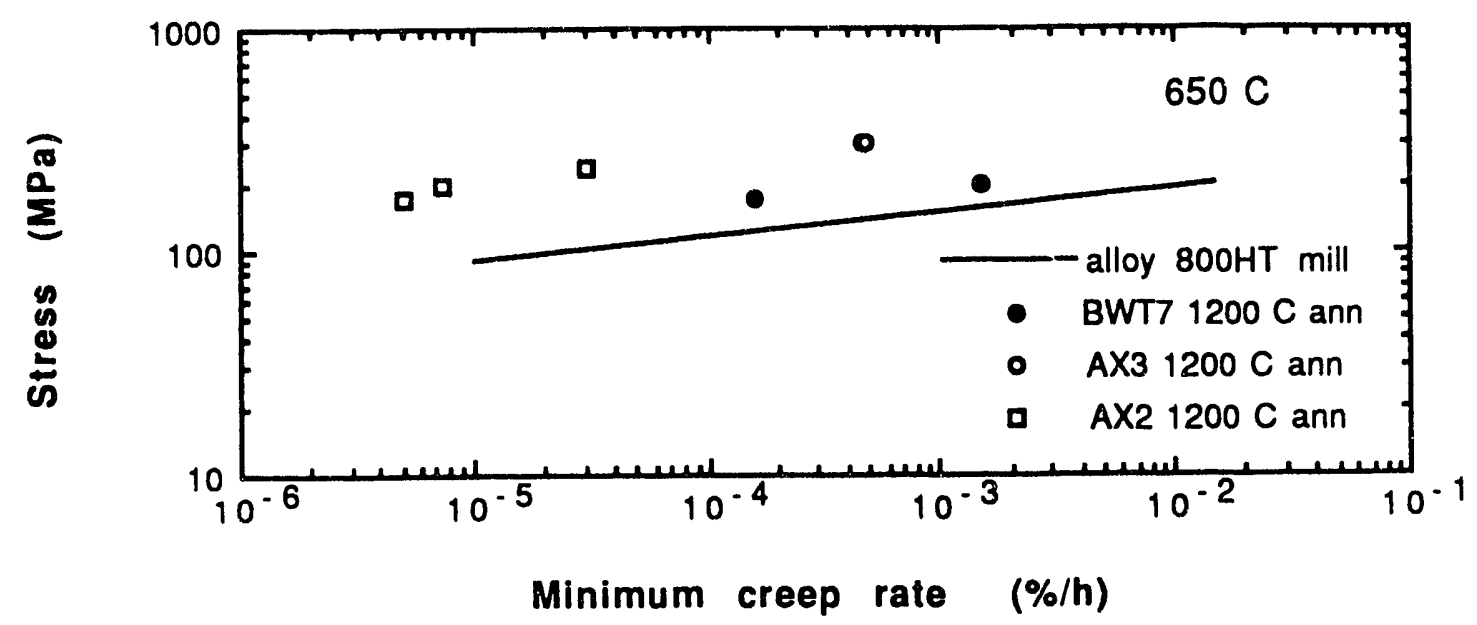
$650^{\circ} \mathrm{C}$.

Fig. 2.2-9. Comparison of minimum creep rates for $20 \% \mathrm{Cr}-30 \% \mathrm{Ni}-\mathrm{Fe}$ alloys at

Table 2.2-4. Chemical composition of alloys for hot-gas cleanup vessel internals (wt \%)

\begin{tabular}{lcccccc}
\hline & RA333 & Alloy 556 & IC221 & IC396M & HR160 & 617 \\
\hline $\mathrm{C}$ & 0.05 & 0.10 & - & - & 0.05 & 0.07 \\
$\mathrm{Cr}$ & 24.4 & 21.55 & 7.8 & 7.7 & 27.9 & 20.3 \\
$\mathrm{Ni}$ & 45.1 & 22.1 & $\mathrm{Ba1}$ & $\mathrm{Bal}$ & 37.4 & 57.35 \\
$\mathrm{Mo}$ & 2.74 & 2.83 & - & 3.0 & - & 8.58 \\
$\mathrm{Mn}$ & 1.53 & 0.95 & - & - & 0.40 & 0.05 \\
$\mathrm{Si}$ & 1.22 & 0.40 & - & - & 2.78 & 0.16 \\
$\mathrm{Fe}$ & 16.7 & $\mathrm{Bal}$ & - & - & 1.6 & 1.0 \\
$\mathrm{Al}$ & 0.06 & 0.13 & 8.5 & 8.0 & - & 0.76 \\
$\mathrm{Co}$ & 2.93 & 18.18 & - & - & 29.0 & 11.72 \\
$\mathrm{Ti}$ & - & - & - & - & 0.46 & - \\
$\mathrm{Nb} / \mathrm{Ta}$ & - & 0.75 & - & - & - & - \\
$\mathrm{W}$ & 3.02 & 2.45 & - & - & - & - \\
$\mathrm{N}$ & 0.028 & 0.16 & - & - & 0.003 & - \\
$\mathrm{La}$ & - & 0.039 & - & - & - & - \\
$\mathrm{Zr}$ & - & 0.012 & 1.7 & 0.8 & - & - \\
$\mathrm{B}$ & - & 0.002 & 0.02 & 0.01 & - & \\
\hline
\end{tabular}


and IC396M. Research is being directed at producing the data needed for high-temperature component design, rather than optimization of chemistry or fabrication processes, and work underway includes creep-fatigue, thermal-mechanical fatigue, and the development of parameters needed in design evaluations.

Alloy 556 was selected as ar. alternate to RA333 and $800 \mathrm{H}$ for the construction of the tubesheet for the hot-gas cleanup vessel in the Tidd PFBC. ${ }^{12}$ The tensile and creep rupture data provided by the alloy vendor were judged to be adequate for the analysis, but fatigue and creep-fatigue data were lacking. To provide information needed in the analysis, a series of continuous cycling fatigue tests was performed at temperatures in the range $25,300,500,750$, and $871^{\circ} \mathrm{C} .{ }^{13}$ Curves constructed from the data at three temperatures are compared to alloy $800 \mathrm{H}$ and $800 \mathrm{HT}$ in Fig. 2.2-10. The fatigue resistance of the 556 alloy was found to be superior to alloy $800 \mathrm{H}$.

The nickel-chromium-aluminides offer an advantage for service under conditions of low primary stress and high transient loadings because they possess high yield strengths and relatively poor creep strengths. This combination reduces the likelihood of plastic strains during transients and the rapid relaxation of any residual stresses that would produce creep for a simulated Tidd plant power cycle revealed satisfactory performance of the intermetallic alloy. ${ }^{12}$ Additional research was undertaken on an electroslag casting of alloy IC396M. Most tensile, creep, and relaxation testing was completed, and some of the results have been summarized in Fig. 2.2-11. This figure plots stress versus log time for relaxation tests starting near the yield strength and extending to approximately $100 \mathrm{~h}$. High yield strengths and rapid relaxation rates were observed in the IC396M. A few fatigue tests and creep-fatigue tests will be undertaken on the material. Testing of HR160 will also be started.

Table 2.2-5. Creep properties of ternary iron aluminides

\begin{tabular}{|c|c|c|c|c|c|}
\hline $\begin{array}{c}\text { Alloy } \\
\text { composition } \\
(a t .8)\end{array}$ & $\begin{array}{l}\text { Rupture } \\
\text { life } \\
\text { (h) }\end{array}$ & $\begin{array}{l}\text { Ductility } \\
(\&)\end{array}$ & $\begin{array}{l}\text { Minimum } \\
\text { creep rate } \\
\left(s^{-1}\right)\end{array}$ & $\begin{array}{l}\text { Activation } \\
\text { energy } \\
\text { (kcal/mole) }\end{array}$ & $\begin{array}{c}\text { Creep } \\
\text { exponent }\end{array}$ \\
\hline $\mathrm{Fe}-28 \mathrm{Al}$ & 0.6 & 37.0 & $8.5 \times 10^{-3}$ & 83 & $3.5, \quad 7.7$ \\
\hline $\mathrm{Fe}-28 \mathrm{Al}-2 \mathrm{Mo}$ & 49.9 & 44.3 & $1.3 \times 10^{-4}$ & 80 & $1.4,6.8$ \\
\hline $\mathrm{Fe}-28 \mathrm{Al}-1 \mathrm{Nb}$ & 304.0 & 37.3 & $1.4 \times 10^{-6}$ & 80 & $1.8,19$ \\
\hline
\end{tabular}

\footnotetext{
aHeat treated to produce $80 \mu \mathrm{m}$ grain size, then $4 \mathrm{~d}$ at $500^{\circ} \mathrm{C}$ for ordering. bProperty measured at $650^{\circ} \mathrm{C}$ and $138 \mathrm{MPa}$.

'Property measured at $138 \mathrm{MPa}$.

dProperty measured at $625-650^{\circ} \mathrm{C}$.
} 
ORNL-DWG 91.9719

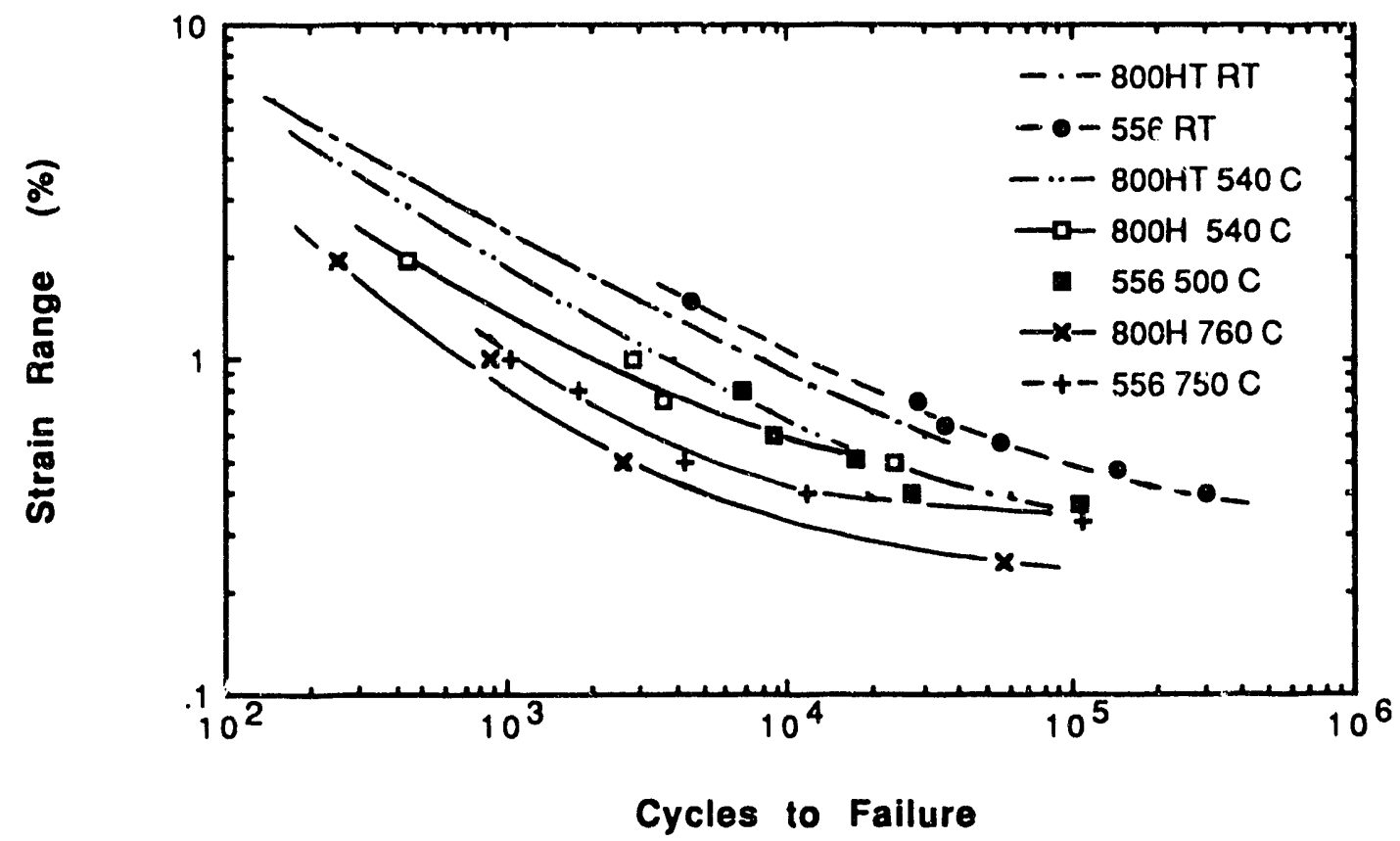
$800 \mathrm{HT}$.

Fig. 2.2-10. Comparison of the low cycle fatigue resistance of alloy 556 with $800 \mathrm{H}$ and

ORNL-DWG 91-9720

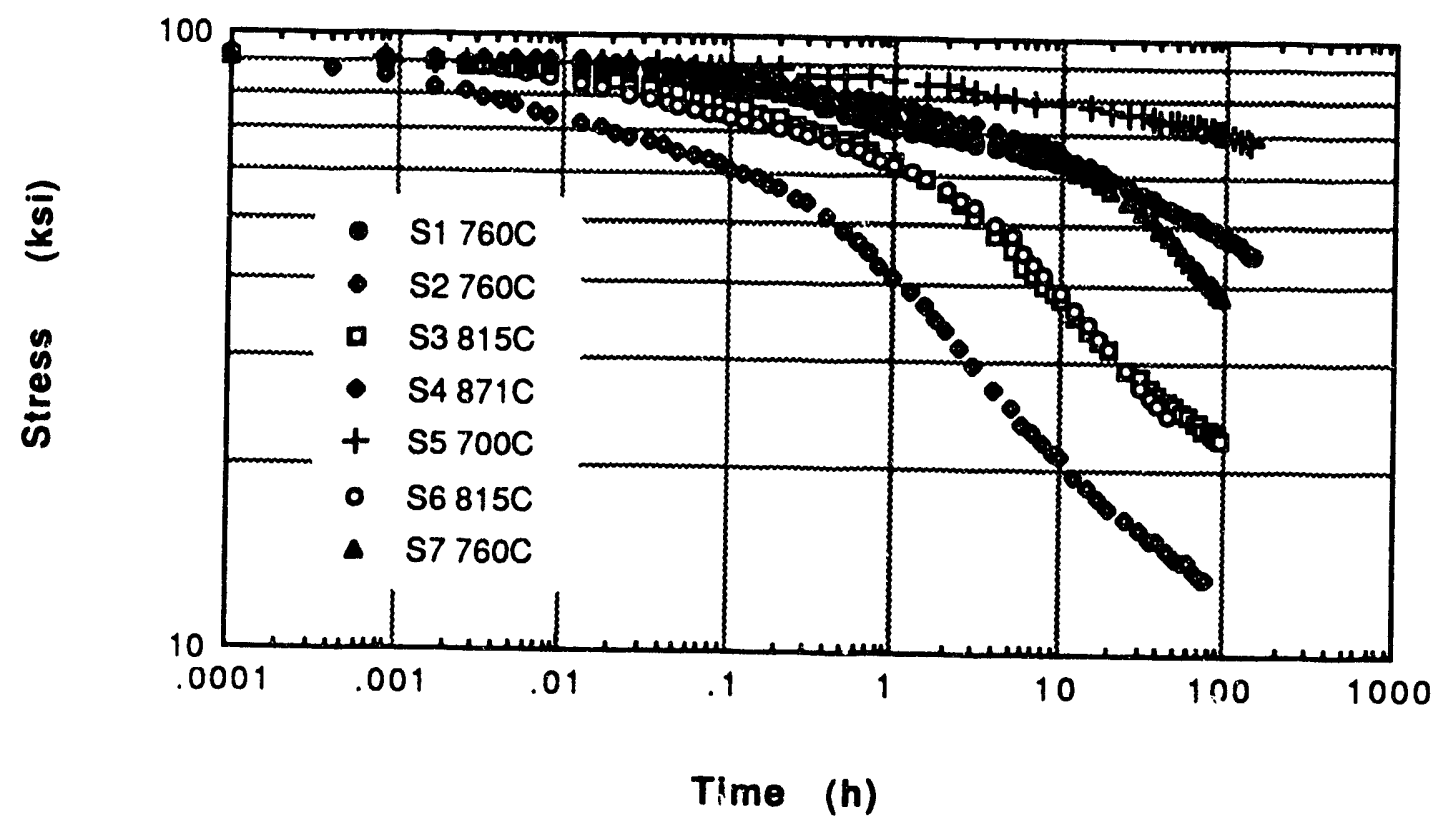

Fig. 2.2-11. Typical relaxation curves for IC396M. 
Long-time testing of HT-UPS lean austenitic stainless steels continued to show that the alloys have excellent strength and ductility.

Stress-rupture testing of transverse (cross) weldments in HT-UPS alloys joined with different filler metals revealed that strength was controlled by the strength of the filler metal. Alloy 556 was found to be the strongest at temperatures above $650^{\circ} \mathrm{C}$.

Creep-rupture testing of modified alloy $800 \mathrm{H}$ tubing (HT-UPS alloy BWT7) indicated lower strength than the AX series plate products but strengths superior to alloy $800 \mathrm{HT}$ were observed.

Experimental evaluation was begun of candidate alloys (RA333, alloy 556, and IC396M) for hot-gas cleanup vessel internals. Fatigue testing of alloy 556 was completed at a number of temperatures, and progress was made in the development of a creep law for the nickel-chromium-aluminide alloy 396M.

\subsubsection{References}

1. P. L. Rittenhouse, et al., Assessment of Materials Needs for Advanced Steam Cycle Coal Fired Plants, ORNL-6274, 1985.

2. R. W. Swindeman et al., Alloy Design Criteria and Evaluation Methods for Advanced Austenitic Alloys in Steam Service, ORNL-6274 (May 1986).

3. P. J. Maziasz, "Developing an Austenitic Stainless Steel for Improved Performance in Fossil Power Facilities," J. Met. 41, 14-20 (1989).

4. R. W. Swindeman et al., Evaluation of Advanced Austenitic Alloys Relative to Alloy Design Criteria for Steam Service - Part 1- Lean Stainless Steels, ORNL-6629 (May 1990).

5. C. D. Lundin et al., The Hot Ductility and Hot Cracking Behavior of Modified 316 Stainless Steels Designed for High Temperature Service, University of Tennessee, ORNL/Sub/88-07685/01 (1989).

6. Y. Sawaragi, H. Teranishi, and K. Yoshikawa, "The Development of Newly Steel with High Elevated Temperature Strength and High Corrosion Resistance for Boiler," Proceedings, International Conference on Creep, Japan Society of Mechanical Engineers, Tokyo, Japan, pp. 238-44, 1988.

7. T. Takahashi et al., "Development of a High Strength $25 \mathrm{Ni}-20 \mathrm{Cr}$ Steel for Tubes in Ultra Supercritical Power Boilers," paper 41-1 in Second International Conference on Improved Coal Fired Power Plants, EPRI publication GS-6422, 1989.

8. R. W. Swindeman et al., Procurement and Screening Test Data for Advanced Austenitic Alloys for $650^{\circ} \mathrm{C}$ Steam Service (Part 2, Final Report), ORNL/TM-10206/P2 (April 1988). 
9. H. Doi et al., "Effects of $\mathrm{Nb}$ and Mo on Creep Rupture Strength of $23 \mathrm{Cr}-34 \mathrm{Ni}$ Iron Base Alloy," pp. 227-32 in Proceedings, International Conference on Creep, Japan Society of Mechanical Engineers, Tokyo, Japan, 1986.

10. M. Topolski, Evaluation of the Fabricability of Advanced Austenitic Tubing, Final Report CRD \#1207, RDD:91:4500-01-01:01, Babcock \& Wilcox Alliance Research Center, Alliance, OH (March 1991).

11. T. E. Lippert et al., Performance Evaluation of a Ceramic Cross-Flow Filter on a Bench-Scale Coal Gasifier, DOE/MC/21338-2749, Vol. 1 and 2, U.S. Department of Energy, Morgantown Energy Technology Center, Morgantown, WV (September 1989).

12. R. W. Swindeman et al., Evaluation of Advanced Austenitic Alloys Relative to Alloy Design Criteria for Steam Senvice - Part 2 - 20 to 30\% Chromium Alloys, ORNL-6629 (May 1990).

13. T. Krukemyer, Crecp-Fatigue of a 22Cr-20Ni-18Co-Fe Alloy at Elevated Temperatures, University of Toledo, Masters Thesis (Draft copy, June 1991).

2.2.3 Development of Iron Aluminides - C. G. McKamey and P. J. Maziasz

Our efforts to develop $\mathrm{Fe}_{3} \mathrm{Al}$-based iron aluminides for fossil energy structural applications continue. Using alloy development and thermomechanical processing techniques, alloys with room temperature tensile ductilities of $10-20 \%$ and yield strengths of $500 \mathrm{MPa}$ at temperatures to $600^{\circ} \mathrm{C}$ have been produced. Preliminary creep rupture studies have shown that $\mathrm{Fe}_{3} \mathrm{Al}$, which has very-poor creep resistance, can be strengthened significantly by alloy additions, particularly by small additions of $\mathrm{Mo}, \mathrm{Nb}$, and $\mathrm{Zr}$. The reason for this improvement in creep life with alloying additions is under study and may be the result of a combination of factors, including grain boundary strengthening, resistance to dynamic recrystallization during stressing, precipitation strengthening, and changes in dislocation formation and mobility. Preliminary transmission electron microscopy analysis indicates that $\mathrm{Fe}_{3} \mathrm{Al}$ fails along weak grain boundaries and/or sub-grain boundaries formed by dislocation pileups. Addition of niobium affects the dislocation structure and produces precipitates which strengthen high-angle boundaries and pin dislocations; together, these factors appear to reduce dislocation subgrain boundary formation. These results indicate that controlling the composition and the microstructure through macro-and microalloying and/or thermomechanical processing can further improve the creep-rupture life and reduce the minimum creep rate.

Iron aluminides based on $\mathrm{Fe}_{3} \mathrm{Al}$ have excellent oxidation and corrosion resistance. ${ }^{1}$ However, until recently their potential use as structural material has been hindered by low 
room temperature ductility $(<5 \%)$ and a drop in strength above $600^{\circ} \mathrm{C}^{2}$ Recent studies indicate that the poor ambient-temperature ductility observed in many aluminides is often caused by dynamic hydrogen embrittlement resulting from the dissociation of water molecules in the environment by aluminum atoms on the surface of the alloy. ${ }^{3-6}$ This environmental embrittlement can be minimized through modification of alloy chemistry, microstructure, and surface condition. $^{\text {s-8 }}$ Development efforts at this laboratory have indicated that by controlling alloy chemistry and thermomechanical processing, $\mathrm{Fe}_{3} \mathrm{Al}$-based alloys can achieve ambient temperature tensile ductilities of $10-20 \%$ and tensile yield strengths of as high as $500 \mathrm{MPa}{ }^{7}$ Preliminary studies of $\mathrm{Fe}_{3} \mathrm{Al}$-based ternary alloys have shown that additions of molybdenum or niobium result in improved creep rupture properties. At $593^{\circ} \mathrm{C}\left(1100^{\circ} \mathrm{F}\right)$ and $207 \mathrm{MPa}$ (30 ksi), the binary lasted only $2-5 \mathrm{~h}$, while the niobium-containing ternary alloy lasted over 300 h. ${ }^{9}$ These improved properties make $\mathrm{Fe}_{3} \mathrm{Al}$-based alloys more competitive with conventional austenitic and ferritic steels.

High-temperature creep in many ordered alloys and intermetallics is controlled by many of the same mechanisms that operate in ordinary metals and alloys (i.e., diffusional processes, dislocation glide and climb, and grain boundary sliding), but with some additional effects due to the ordered atomic structure. The activation energy for creep is approximated by the activation energy for self-diffusion because the above mechanisms involve the formation, mobility, and absorption of vacancies. ${ }^{10}$ Diffusional processes are slightly different in ordered lattices because the distance between equivalent sites is longer. These factors alone would result in higher activation energies and decreased creep rates. However, ordered materials also have additional features such as non-stoichiometry, anti-phase domain boundaries, and superdislocations whose effects on defect concentrations are not well known. $\mathrm{Fe}_{3} \mathrm{Al}$, however, has been known for some time to have very poor creep resistance. ${ }^{2}$ Although niobium and, to a lesser extent, molybdenum greatly improve the creep rupture resistance as ternary additives, 9,11 they do not necessarily provide room temperature ductility. With additions of other elements whose primary effect is to produce room-temperature ductility, synergistic effects become important. One purpose of the present phase of our alloy development program is to study such synergistic effects and separate the positive from negative synergisms, so that $\mathrm{Fe}_{3} \mathrm{Al}$-based alloys can be produced with improved creep rupture resistance to temperatures of $650-700^{\circ} \mathrm{C}$, adequate room temperature tensile ductility $(>10 \%)$, and still be weldable, fabricable, and maintain their excellent corrosion resistance. This paper 
will emphasize our recent efforts to determine the effects of alloying additions on high temperature creep properties of iron aluminides. Included will be recent analytical studies to determine the mechanism involved in the improved creep resistance with the addition of niobium, and the synergistic mechanical effects produced by further alloying of the molybdenum- or niobium-containing ternary alloys.

All $\mathrm{Fe}_{3} \mathrm{Al}$ alloys for this study were prepared by arc-melting and drop casting into chilled copper molds. Hot rolling to $0.76-\mathrm{mm}$-thick sheet was accomplished at $1000-600^{\circ} \mathrm{C}$. Flat tensile specimens $(0.76 \times 3.18 \times 12.7 \mathrm{~mm})$ were mechanically punched from the hot rolled sheet. The binary and ternary alloys containing molybdenum or niobium were heat treated to produce approximately the same grain size of $80 \mu \mathrm{m}\left(1 \mathrm{~h}\right.$ at 750,900 , and $1000^{\circ} \mathrm{C}$, respectively), followed by $3-5 \mathrm{~d}$ at $500^{\circ} \mathrm{C}$ for $\mathrm{DO}_{3}$ ordering. Creep rupture tests to determine creep parameters were performed at $550-750^{\circ} \mathrm{C}$ in air using stresses of $34-276 \mathrm{MPa}$. The modes of failure for the binary $\mathrm{Fe}_{3} \mathrm{Al}$ and for the ternary alloy containing niobium were determined using optical metallography, scanning electron microscopy (SEM), and transmission electron microscopy (TEM).

For the second part of this study, a variety of compositions based on the $\mathrm{Fe}_{3} \mathrm{Al}$-Mo and - Nb tcrnary alloys were produced by the same fabrication steps listed above. After punching, the specimens were given a standard heat treatment of $1 \mathrm{~h}$ at $850^{\circ} \mathrm{C}$ for recrystallization and 5-7 $\mathrm{d}$ at $500^{\circ} \mathrm{C}$ to produce the $\mathrm{DO}_{3}$ ordered structure. This heat treatment produced various grain sizes, depending on composition, and only partial recrystallization in some of the more complicated compositions. (At this point in the program, no systematic study has yet been made to determine the effects of heat treatment and grain size on the creep-rupture properties.) For comparison between alloy compositions, all creep rupture tests were performed in air at $593^{\circ} \mathrm{C}$ and $207 \mathrm{MPa}$.

Table 2.2-5 shows creep-rupture data (at $593^{\circ} \mathrm{C}$ and $207 \mathrm{MPa}$ ) reported earlier for binary $\mathrm{Fe}_{3} \mathrm{Al}$ and the ternary alloys containing either molybdenum or niobium. ${ }^{9}$ Although the addition of molybdenum reduces the minimum creep rate by two orders of magnitude, the longer creep-rupture life and even lower creep rate for the niobium-containing alloy indicates that niobium is the best ternary addition for improving creep resistance in $\mathrm{Fe}_{3} \mathrm{Al}$ based alloys. The creep activation energy measured for these alloys is slightly higher than the activation energy for either self-diffusion of iron $(60-70 \mathrm{kcal} / \mathrm{mole})^{12-14}$ or for the diffusion of aluminum in iron (45-60-kcal/mole), ${ }^{2,14,15}$ suggesting that, in these alloys, the dominant creep mechanism involves diffusional processes (such as vacancy emission from grain boundaries or 
superdislocations). The rate-controlling mechanisms for these three alloys depend upon the applied stress at $625-650^{\circ} \mathrm{C}$ (Table 2.2-5), with higher stress exponents occurring at the higher strain rates. These stress exponents provide guidelines for determination of the rate-controlling mechanisms. At low stresses, an exponent of $\mathbf{3 . 5}$ for the binary alloy indicates that creep is controlled by a viscous glide mechanism, while exponents of 1-2 for the two ternary alloys suggest that bulk or grain-boundary diffusion is their rate-controlling mechanism. At higher stresses, exponents between 6.5 and 8 for the binary and the molybdenum-containing ternary suggest dislocation climb as the rate controlling mechanism. A very large exponent of 19 was measured for the niobium containing alloy, which suggests further strengthening of the dislocation structure against climb (i.e., precipitation strengthening). The effects of niobium in this alloy may be due to alloy effects on dislocation-dislocation interactions, as well as dislocation pinning by precipitates which were detected in the microstructure using TEM. ${ }^{11}$

Niobium appears to be beneficially effecting creep resistance in several ways. Figure 2.2-12 shows the microstructure of the binary alloy and the ternary containing niobium after rupture at $650^{\circ} \mathrm{C}$ and $138 \mathrm{MPa}$. By measuring the length of the specimens before and after rupture, an elongation of $37 \%$ was determined for both alloys. However, the binary $\mathrm{Fe}_{3} \mathrm{Al}$ alloy experienced excessive separation along the grain boundaries that may be related to creep-void evolution along those boundaries, particularly at triple-points, and easy crack propagation. A lot of "squiggly" grain boundaries were also seen. Fracture appears to be intergranular with little necking or plasticity of individual grains. By contrast, there appears to be good mechanical integrity along the grain boundaries of the niobium-containing ternary alloy. There is virtually no intergranular separation and only a few large creep voids are observed. Failure occurs in a ductile mode via plastic instability with significant necking and with individual grains showing significant deformation. The ȘEM fractographs of these two alloys, shown in Fig. 2.2-13, illustrate these differences in their fracture behavior.

TEM of the binary and niobium-containing ternary alloys provided further evidence for effects of the niobium addition. Figure 2.2-14 shows the binary alloy creep ruptured at $625^{\circ} \mathrm{C}$ and $34.5 \mathrm{MPa}$. Very few dislocations were observed along the high angle grain boundaries or within the matrix. Instead, dislocations appeared to pile-up and form low-angle subgrain boundaries in which their movement via glide or climb-glide was dramatically restricted. All the evidence together indicates that the low creep life and intergranular failure 
ORNL-PHOTO $.4469-91$
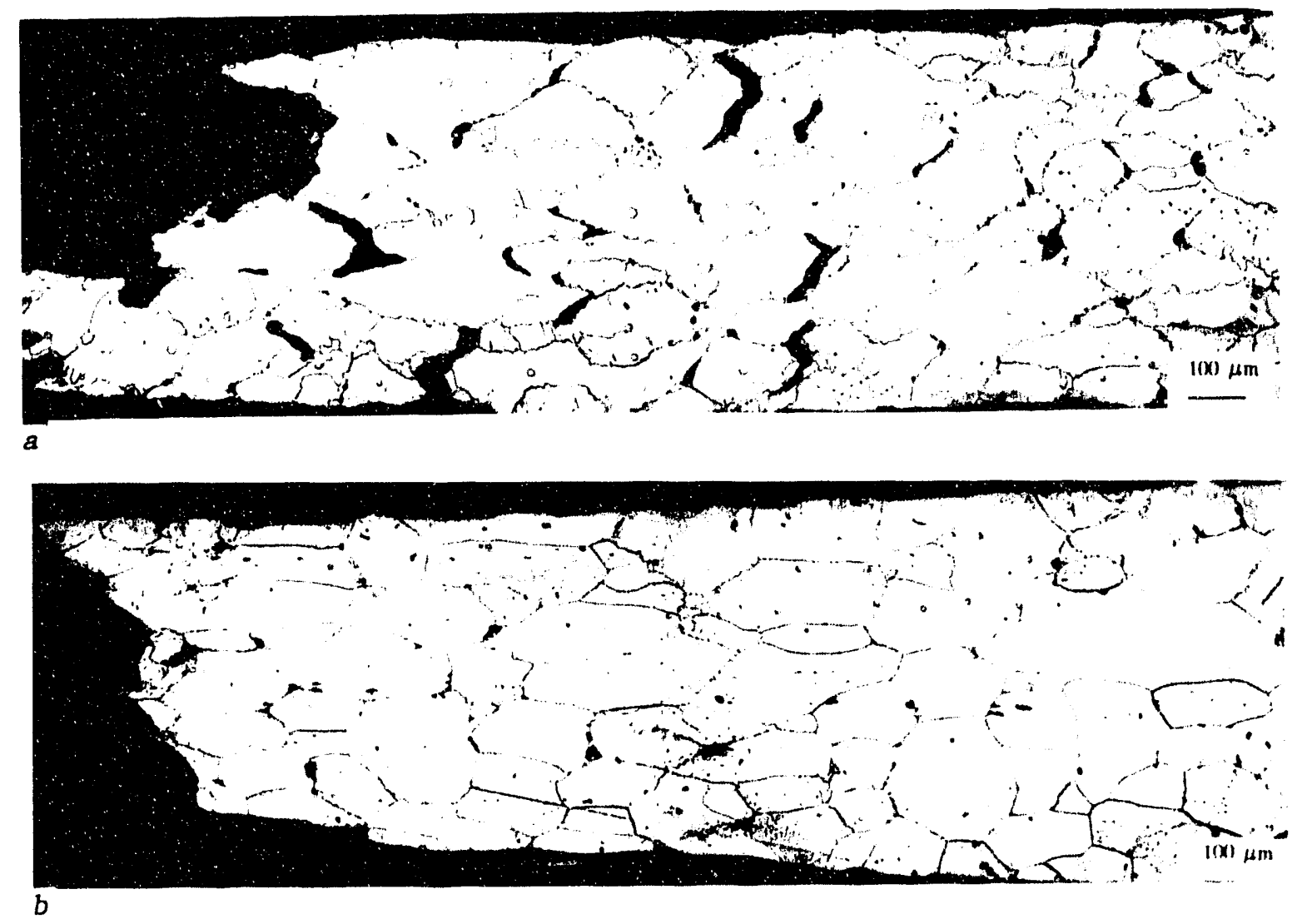

Fig. 2.2-12. Optical micrographs showing microstructure of the binary $\mathrm{Fe}_{3} \mathrm{Al}$ alloy (a) and the ternary alloy containing niobium (b) after rupture at $650^{\circ} \mathrm{C}$ and $138 \mathrm{MPa}$.

ORNL-PHOTO 4470-91
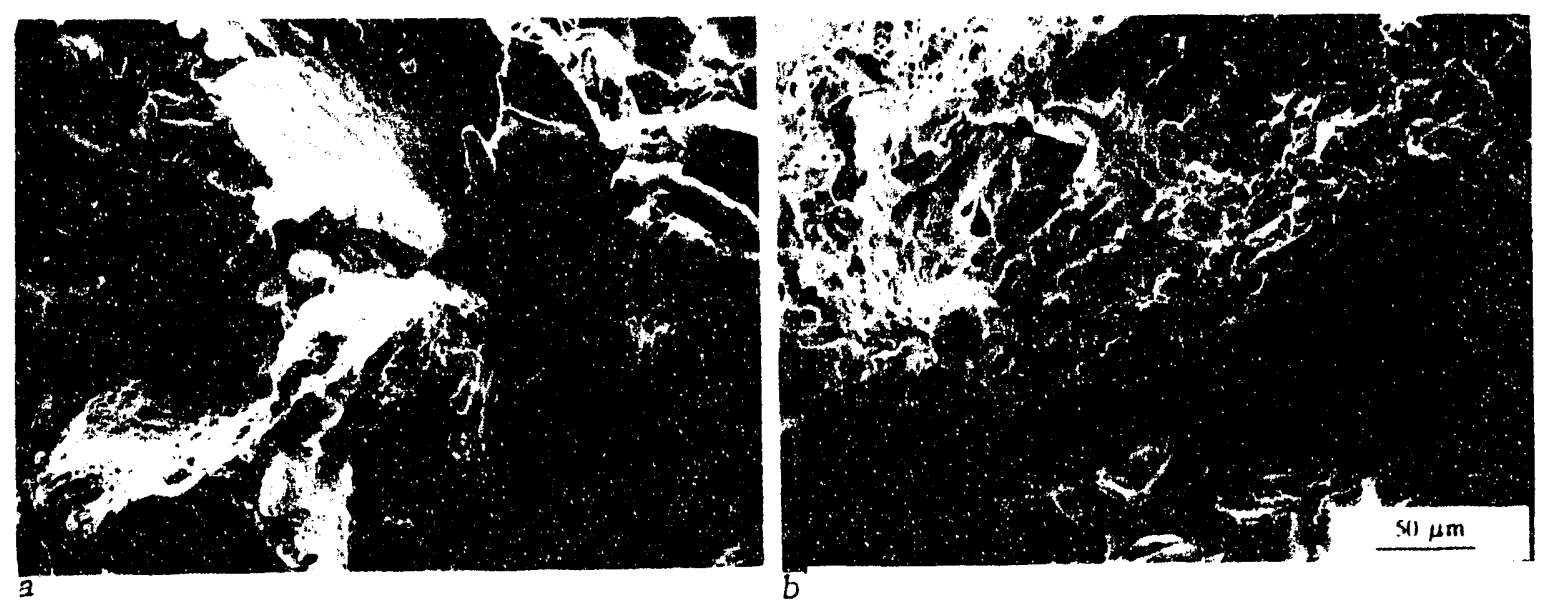

Fig. 2.2-13. SEM fractographs of creep-ruptured specimens showing (a) brittle failure of $\mathrm{Fe}_{3} \mathrm{Al}$ and (b) ductile failure of $\mathrm{Fe}_{3} \mathrm{Al}+\mathrm{Nb}$. 
of this alloy was probably due to weak high-angle grain boundaries and the reduced ability of dislocations to move or multiply to produce matrix plasticity.

By contrast, TEM of the niobium-containing ternary alloy (Fig. 2.2-15) showed many dislocation networks in the matrix, with very little formation of subgrain arrays. Niobium-rich precipitates were found on the high-angle grain boundaries, along with dislocations, both of which should strengthen the grain boundaries. Smaller zirconium-and-niobium-rich precipitates (zirconium would be a contaminant in this alloy) were also observed in the matrix, and appeared to pin dislocations. The ductile failure mode was a result of both the grain boundaries and the matrix being able to deform plastically, consistent with the microstructure observed. This alloy also had a longer creep-rupture life because precipitates and dislocations strengthened the grain boundaries while dislocation-dislocation and dislocation-precipitate interactions strengthened the matrix.

With the objective of producing alloy compositions which combine high-temperature creep-rupture resistance with good room-temperature tensile properties, several more complex compositions were studied. Table 2.2-6 shows the effect of other elemental additions on the creep properties of the molybdenum- and niobium-modified alloys tested at $593^{\circ} \mathrm{C}$ and $207 \mathrm{MPa}$. The number in parenthesis after the average rupture life is the total number of tests for that alloy. Although niobium was the best ternary addition for creep resistance, the addition of most other elements to the $\mathrm{Fe}_{3} \mathrm{Al}-\mathrm{Nb}$ ternary alloy resulted in decreased rupture lives and increased minimum creep rates for all combinations tested. Even the addition of further niobium to the 2 at.\% level produced a reduction in rupture resistance.

The molybdenum-containing ternary alloy was strengthened further by additions of zirconium or niobium, while chromium and boron had little effect on rupture life. While addition of only 0.1 at. $\% \mathrm{Zr}$ resulted in rupture lives of over $200 \mathrm{~h}$, the addition of zirconium and niobium in combination resulted in an average life of over $450 \mathrm{~h}$. Note that the addition of carbon to those alloys caused a dramatic reduction in the rupture life and an increase in the minimum creep rate. This was substantiated on other compositions for carbon levels down to 0.1 at.\%. However, carbon has been shown to be beneficial for weldability, and synergistic effects of carbon with other alloying elements that have not yet been tested, or the lowering of the carbon level, could produce more positive effects on creep resistance. [Recently an alloy containing $0.03 \% \mathrm{C}$ produced a very good creep-rupture life of almost $400 \mathrm{~h}$ (see Table 2.2-7).] If The zirconium-and-niobium-rich fine precipitates observed by TEM to pin dislocations are carbides, then some potential for optimizing such strengthening still exists. 
ORNL-PHOTO $4468-91$

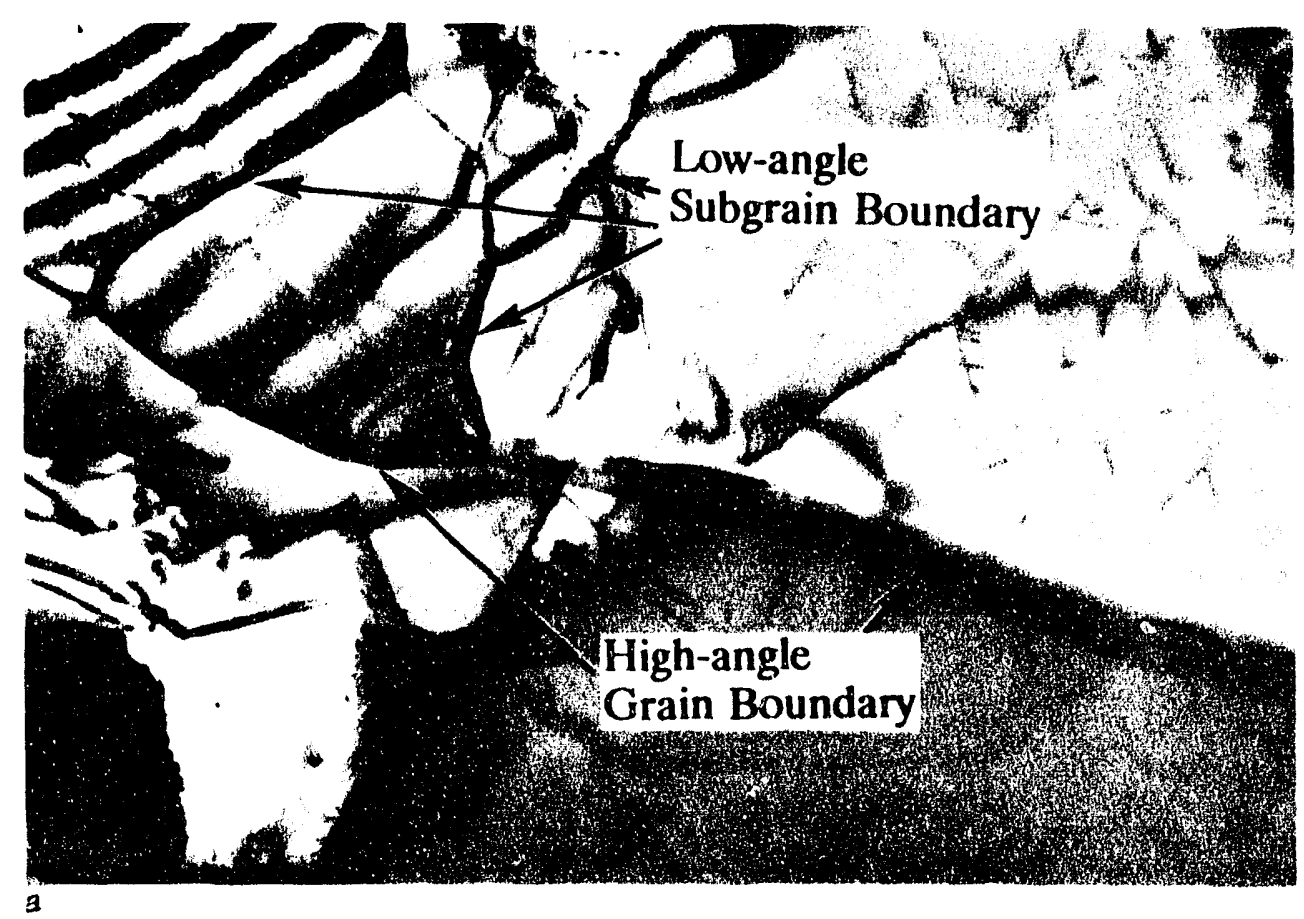

ORNL-PHOTO $4467-91$
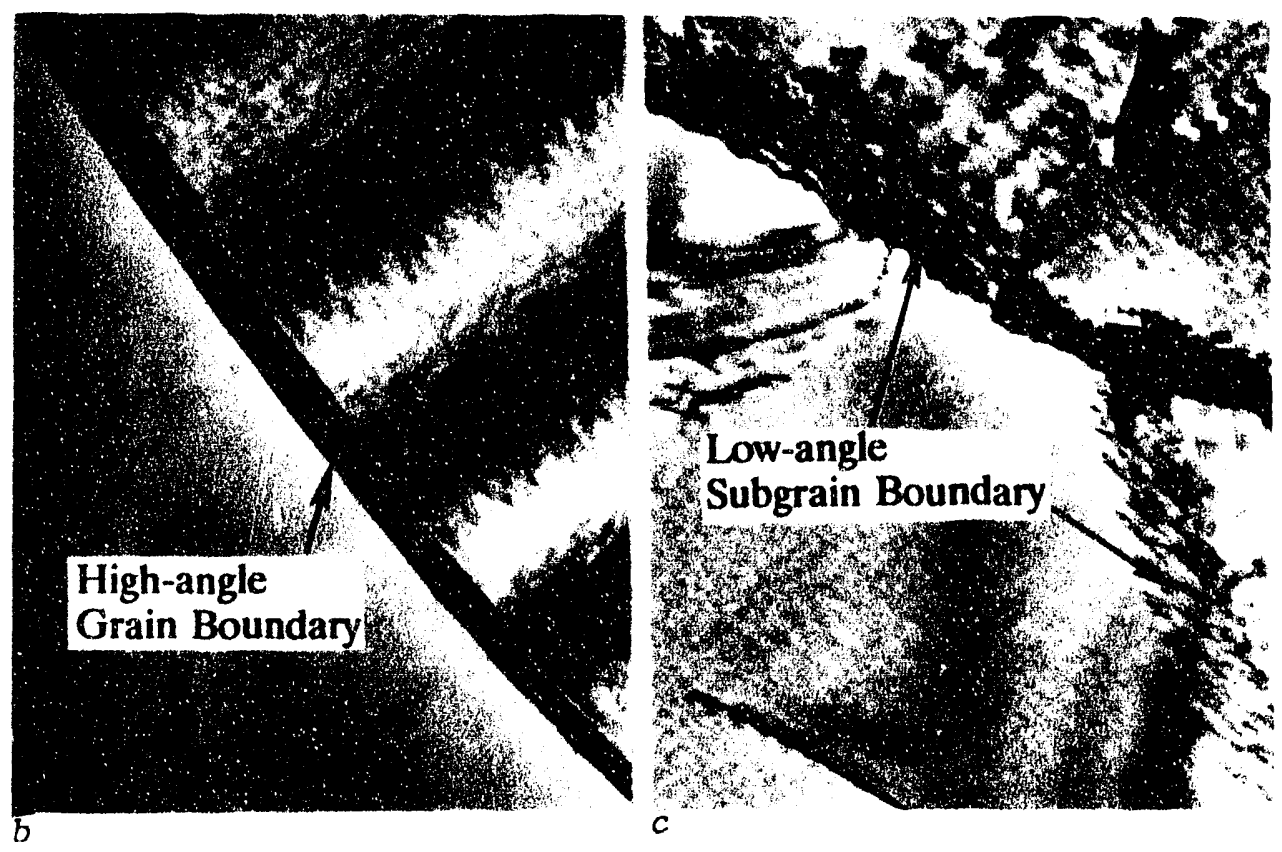

Fig. 2.2-14. Low- (a) and high-magnification (b,c) TEM micrographs of $\mathrm{Fe}_{3} \mathrm{Al}$ showing assembly of dislocations into low-angle subgrain boundaries. 


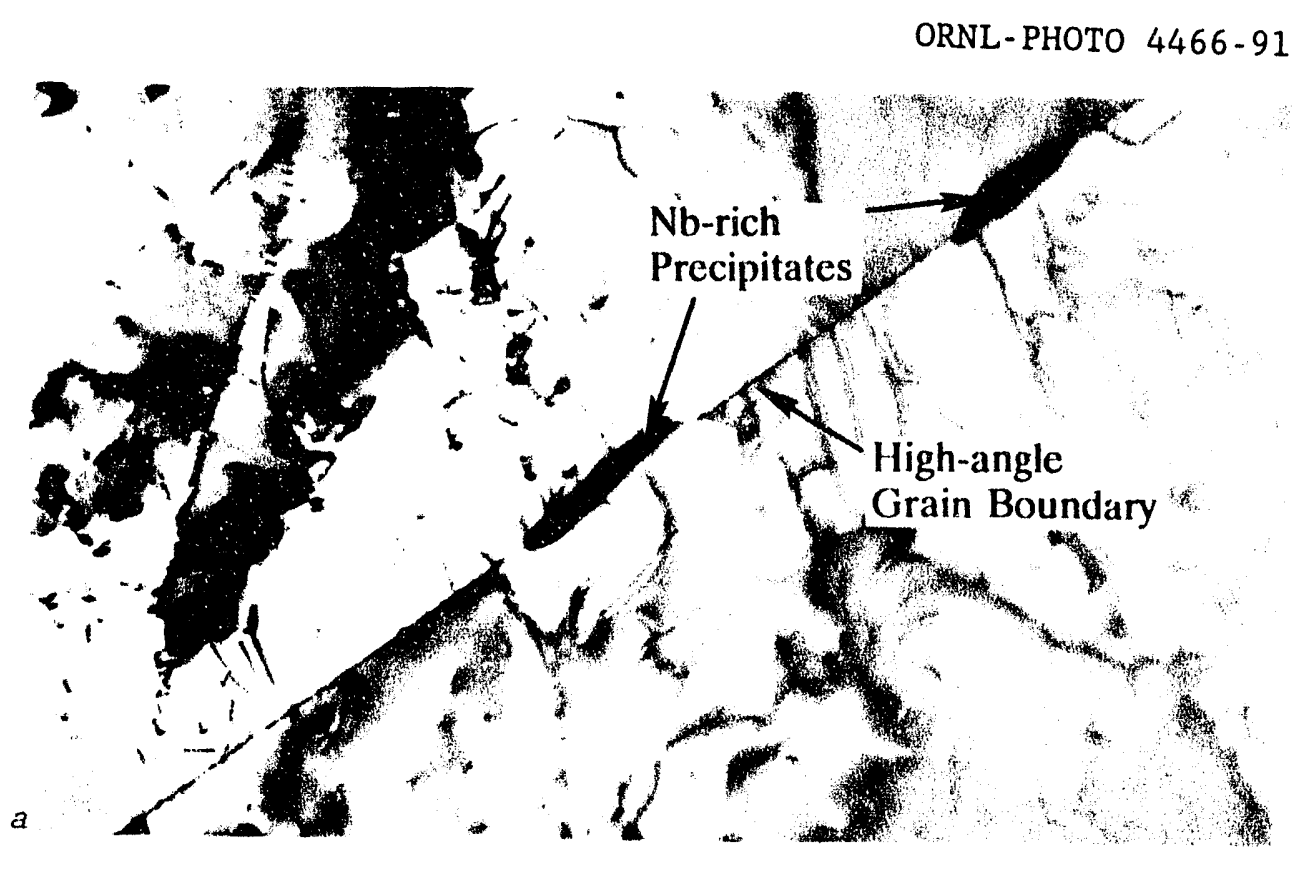

ORNL-PHOTO 4471-91

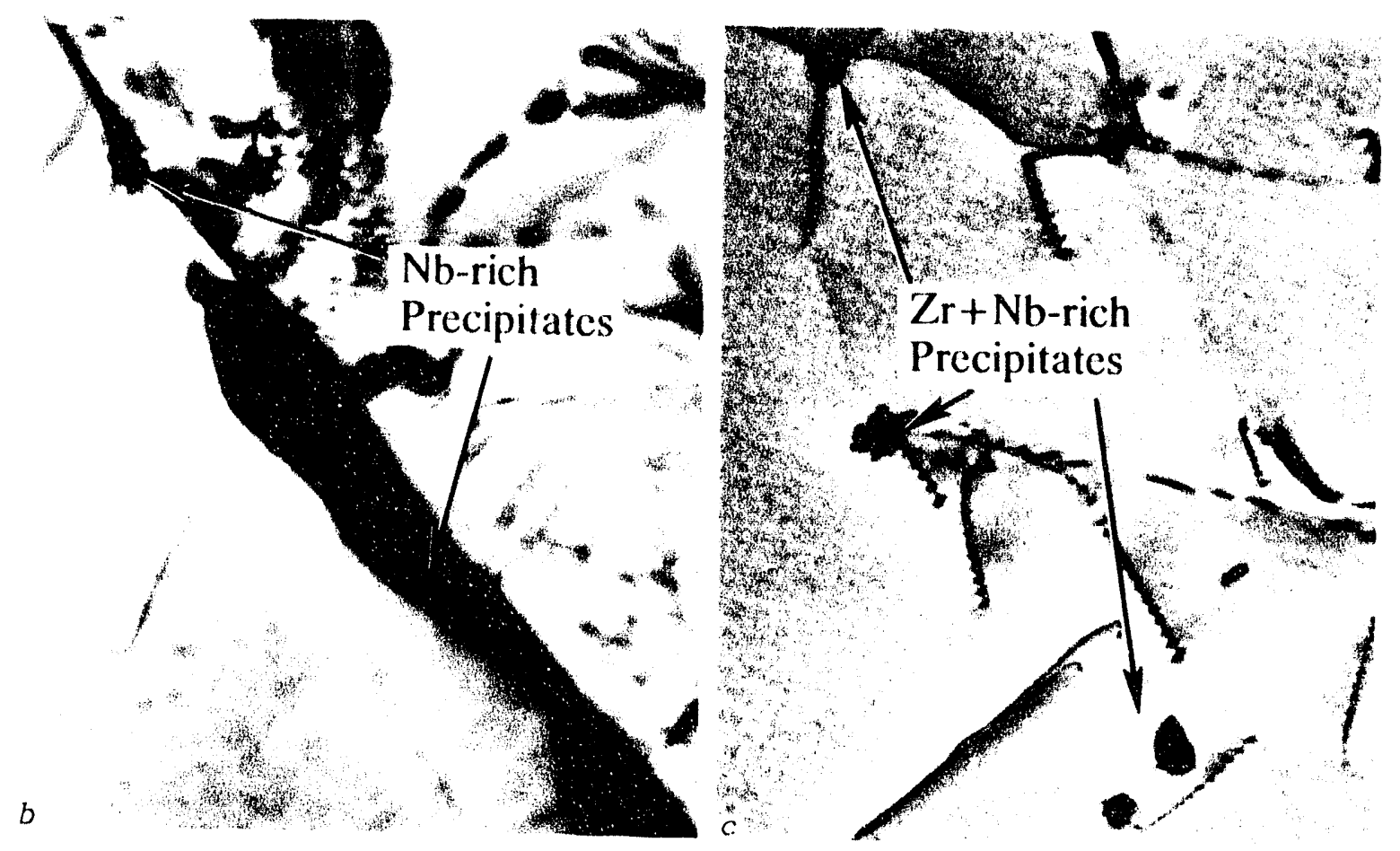

Fig. 2.2-15. Low- (a) and high-magnification (b,c) TEM micrographs of Nb-containing alloy showing $\mathrm{Nb}$-rich precipitates decorating high-angle grain boundary and small $\mathrm{Nb}-\mathrm{Z}$ :-rich precipitates pinning dislocations in the matrix. 
Table 2.2-6. Effect of alloying on creep properties of $\mathrm{Fe}_{3} \mathrm{Al}$

\begin{tabular}{|c|c|c|c|c|}
\hline Alloy & $\begin{array}{c}\text { Composition } \\
(\text { at. }\end{array}$ & $\begin{array}{c}\text { Rupture I1fe } \\
(h)\end{array}$ & $\begin{array}{c}\text { Elongation } \\
(8)\end{array}$ & $\begin{array}{c}\text { Minimum } \\
\text { creep rate } \\
(8 / h)\end{array}$ \\
\hline FA- 61 & binary & $3.0(2)$ & 31.0 & 10.3 \\
\hline FA- 62 & 2Mo & $81.5(3)$ & 17.5 & 0.15 \\
\hline FA -73 & $2 \mathrm{Mo}, 0.5 \mathrm{~B}$ & $35.5(5)$ & 17.6 & $0.2,0.6$ \\
\hline FA- 91 & $2 \mathrm{Mo}, 0.12 \mathrm{r}$ & $209.5(2)$ & 50.6 & 0.04 \\
\hline FA- 92 & $2 \mathrm{Mo}, 0.1 \mathrm{Zr}, 0.2 \mathrm{~B}$ & 249.0 (1) & 51.4 & 0.08 \\
\hline $\mathrm{FA}-88$ & $2 \mathrm{Mo}, 0.1 \mathrm{Zr}, 0.2 \mathrm{C}$ & $16.5(5)$ & 43.9 & 1.5 \\
\hline FA- 95 & $2 \mathrm{Mo}, 2 \mathrm{Cr}, 0.1 \mathrm{Zr}, 0.2 \mathrm{~B}$ & $223.3(3)$ & 63.2 & 0.08 \\
\hline FA-96 & $2 \mathrm{Mo}, 2 \mathrm{Cr}, 0.5 \mathrm{Nb}, 0.05 \mathrm{~B}$ & $120.8(2)$ & 35.0 & 0.16 \\
\hline FA- 97 & $2 \mathrm{Mo}, 2 \mathrm{Cr}, 0.1 \mathrm{Zr}, 0.2 \mathrm{~B}, 0.5 \mathrm{Nb}$ & $463.4(2)$ & 47.2 & 0.04 \\
\hline $\mathrm{FA}-79$ & $1 \mathrm{Nb}$ & $324.8(2)$ & 26.9 & 0.04 \\
\hline$F A \cdot 115$ & $2 \mathrm{Nb}$ & $41.9(3)$ & 5.4 & 0.8 \\
\hline $\mathrm{FA}-112$ & $1 \mathrm{Nb}, 0.05 \mathrm{~B}$ & $84.4(2)$ & 51.6 & 0.35 \\
\hline $\mathrm{FA}-105$ & $0.8 \mathrm{Nb}, 4 \mathrm{Cr}$ & $63.8(3)$ & 50.9 & 0.5 \\
\hline FA- 81 & $1 \mathrm{Nb}, 4 \mathrm{Cr}, 0.05 \mathrm{~B}$ & 18.1 (3) & 8.3 & 1.2 \\
\hline FA- 93 & $1 \mathrm{Nb}, 4 \mathrm{Cr}, 0.1 \mathrm{Zr}$ & $22.2(3)$ & 9.7 & 0.7 \\
\hline$F A-111$ & $0.8 \mathrm{Nb}, 4 \mathrm{Cr}, 0.5 \mathrm{Mo}, 0.05 \mathrm{~B}$ & $94.6(4)$ & 0.3 & 0.6 \\
\hline
\end{tabular}

A1l alloys contain 28 at. $8 \mathrm{Al}$.

Table 2.2-7. Room temperature tensile properties versus creep-rupture resistance for $\mathrm{Fe}_{3} \mathrm{Al}$-based alloys

\begin{tabular}{|c|c|c|c|c|c|c|c|}
\hline \multirow[b]{2}{*}{ Alloy } & \multirow[b]{2}{*}{$\begin{array}{l}\text { Composition } \\
(\mathrm{at} .8)\end{array}$} & \multirow[b]{2}{*}{$\begin{array}{l}\text { Yleld } \\
\text { (MPa) }\end{array}$} & \multicolumn{2}{|c|}{ RT Tensile } & \multicolumn{2}{|c|}{ Creep rupture ${ }^{b}$} & \multirow[b]{2}{*}{$\begin{array}{c}\mathrm{MCR} \\
(\mathrm{B} / \mathrm{h})\end{array}$} \\
\hline & & & $\begin{array}{l}\text { U1t. } \\
\text { (MPa) }\end{array}$ & $\begin{array}{l}\text { Elong. } \\
\text { (8) }\end{array}$ & $\begin{array}{r}\text { Life } \\
(h)\end{array}$ & $\begin{array}{l}\text { Elong. } \\
\text { (8) }\end{array}$ & \\
\hline FA- 61 & $\mathrm{Fe}-28 \mathrm{Al}$ & 434 & 716 & 8.0 & 3 & 31 & 10.3 \\
\hline $\begin{array}{l}F A-127 \\
F A-129 \\
F A-130\end{array}$ & $\begin{array}{l}+5 \mathrm{Cr}, .5 \mathrm{Nb} \\
+5 \mathrm{Cr}, .5 \mathrm{Nb}, .2 \mathrm{C} \\
+5 \mathrm{Cr}, .5 \mathrm{Mo}, .5 \mathrm{Nb} \\
.12 \mathrm{Zr}, .05 \mathrm{~B}\end{array}$ & $\begin{array}{l}415 \\
384 \\
554\end{array}$ & $\begin{array}{l}302 \\
930 \\
942\end{array}$ & $\begin{array}{l}11.6 \\
16.9 \\
12.6\end{array}$ & $\begin{array}{r}42 \\
22 \\
202\end{array}$ & $\begin{array}{l}55 \\
75 \\
61\end{array}$ & $\begin{array}{l}0.8 \\
0.95 \\
0.1\end{array}$ \\
\hline $\begin{array}{l}F A-97 \\
F A-168\end{array}$ & $\begin{array}{l}+2 \mathrm{Mo}, 2 \mathrm{Cr}, .5 \mathrm{Nb}, \\
.1 \mathrm{Zr}, .2 \mathrm{~B} \\
+5 \mathrm{Cr}, .8 \mathrm{Mo}, .5 \mathrm{Nb} \\
.05 \mathrm{Zr}, .005 \mathrm{~B}, .03 \mathrm{C}\end{array}$ & $>690$ & 676 & $<5.0$ & 463 & 47 & 0.04 \\
\hline
\end{tabular}

"Heat treated $1 \mathrm{~h} / 750^{\circ} \mathrm{C}$ air cooled.

${ }^{b}$ Heat treated $1 \mathrm{~h} / 850^{\circ} \mathrm{C}+3-7 \mathrm{~d} / 500^{\circ} \mathrm{C}$; tested at $593^{\circ} \mathrm{C}, 207 \mathrm{MPa}$, 
Our studies to date indicate that a combination of at least the three elements $\mathrm{Mo}, \mathrm{Nb}$, and $\mathrm{Zr}$ is needed to produce the best creep rupture lives in these alloys. Alloy FA-97, containing a combination of $\mathrm{Cr}, \mathrm{Mo}, \mathrm{Nb}$, and $\mathrm{Zr}$ is the best alloy tested so far (see Table 2.2-7), highlighting the importance of synergistic alloying effects. If othe- positive synergisms are identified, they may lead to even better creep-rupture resistance. However, large concentrations of hardening elements (such as $\mathrm{Mo}, \mathrm{Nb}, \mathrm{Zr}$, etc.) have a detrimental effect on room temperature tensile ductility: the ductility of FA-97 is less than 5\%. This behavior may also be affected by non-optimum thermomechanical processing of these more complex alloys. Our current efforts are aimed at alloying between the compositions of FA-97 and FA-129, as well as exploring the effects of alternate processing conditions.

Table 2.2-7 shows a progression of alloys from FA-127, which has approximately $12 \%$ room temperature tensile ductility, through FA-129, which has a room temperature ductility of over $15 \%$ but very poor creep strength, to alloy FA-130, which also has about $12 \%$ ductility but improved creep-rupture strength. Studies of alloy compositions that fall between FA-97 and FA-130 are in progress, along with microcharacterization studies to determine the synergistic effects of elemental additions and the mechanisms that lead to better properties behavior.

Our studies have indicated that creep-rupture resistance in binary $\mathrm{Fe}_{3} \mathrm{Al}$ at temperatures near $600^{\circ} \mathrm{C}$ is very poor, with failure occurring through gross separation of grain boundaries, with little plastic deformation of grains. The elements $\mathrm{Nb}$ and Mo have been identified as producing lower minimum creep rates and longer creep-rupture lives. TEM and SEM analysis of the niobium-containing ternary alloy, in particular, indicates that grain boundaries are strengthened and matrix dislocations are pinned by niobium based precipitates. However, large concentrations of these strengthening elements can reduce room temperature tensile ductility and may have adverse effects on weldability and fabricability. Therefore, our present efforts in the alloy development of these alloys for improved creep resistance involves finding the right combination and concentrations of elements and in determining the mechanisms by which these elements produce strengthening. To date, we have determined that a combination of $\mathrm{Mo}, \mathrm{Nb}$, and $\mathrm{Zr}$ produces the best creep-rupture resistance through synergistic mechanisms which are yet to be completely identified. Additions of other elements and their effects on the mechanical, welding, and fabrication properties are also being pursued. 


\subsubsection{References}

1. J. H. DeVan, H. S. Hsu, and M. Howell, SulfidationllOxidation Properties of Iron-Based Alloys Containing Niobium and Aluminum, ORNL/TM-11176, May 1989.

2. C. G. McKamey, J. H. DeVan, P. F. Tortorelli, and V. K. Sikka, to be published in J. Mater. Res. 6(8), (1991).

3. C. T. Liu, E. H. Lee, and C. G. McKamey, Scripta Metal. 23, 875-880 (1989).

4. C. T. Liu, C. G. McKamey, and E. H. Lee, Scripta Metall. 24(2), 385 (1990).

5. C. T. Liu and C. G. McKamey, High Temperature Aluminides and Intermetallics, ed. S. H. Whang, C. T. Liu, D. P. Pope, and J. 0. Stiegler (TMS, Allentown, PA, 1990), p. 133.

6. C. G. McKamey and C. T. Liu, to be published in Proceedings of ADVMAT/91 Environmental Effects on Advanced Materials Symposium, 1991.

7. V. K. Sikka, C. G. McKamey, C. R. Howell, and R. H. Baldwin, Fabrication and Mechanical Properties of Fe Al-Based Aluminides, ORNL/TM-11465, March 1990.

8. C. G. McKamey and C. T. Liu, Scripta Metall. 24, 2119 (1990).

9. C. G. McKamey, Proceedings of the Fourth Annual Conference on Fossil Energy Materials, Oak Ridge National Laboratory, ORNL/FMP-90/1, August 1990, p. 197.

10. N. S. Stoloff and R. G. Davies, Prog. Mater. Sci. 13, 1 (1966).

11. D. M. Dimiduk, M. G. Mendiratta, D. Banerjee, and H. A. Lipsitt, Acta Metall. 36, 2947 (1988).

12. A. Lawley, J. A. Coll, and R. W. Cahn, Trans. Met. Soc. AIME 218, 166 (1960).

13. V. S. Raghunathan and B. D. Sharma, Philos. Mag. A 43(2), 427 (1981).

14. I. A. Akimova, V. M. Mironov, and A. V. Pokoyev, Phys. Met. Metall. 56(6), 175 (1983).

15. A. Vignes, J. Philibert, N. Badia et al; Diffusion Data 3, 269 (1969).

\subsection{CORROSION AND EROSION RESEARCH}

2.3.1 The Measurement of the Mechanical Propertics of Oxide Scales - P. F. Tortorelli and J. R. Keiser

A mechanical properties microprobe (MPM) was used to measure hardness, Young's modulus, and plasticity of scales and bulk oxides by depth-sensing submicron indentation 
testing. Results for oxidized iron aluminide and chromium were within the range of expected values based on data from other methods and were self-consistent with other MPM studies. However, because the hardness and modulus of the scales did not always match those of the corresponding bulk oxide, it is questionable whether scale behavior can always be modeled using bulk properties.

Experiments with polished cross sections of scales yielded more statistically rigorous data than results from top-down indentations but were more difficult to implement because of a much smaller target for indenter placement. The results of this study suggested improvements in the MPM methodology and specimen preparation that should reduce experimental uncertainty, increase the fraction of successful indentations, and yield better resolution of minor differences in properties.

The ability of a metallic material to withstand aggressive oxidizing environments is crucial to the efficient and reliable operation of many high-temperature systems. Therefore, a better understanding of the relevant high-temperature oxidation processes is important in trying to improve alloy design approaches to highly corrosion-resistant materials. To this end, the mechanical properties of oxide scales are being characterized based on the premise that these properties (hardness, modulus, etc.) ultimately determine whether a chemically stable surface oxide will retain its integrity in corrosive, high-temperature environments (see for example, Refs. 1-4) and, thus, whether a particular high-temperature alloy is generally corrosion resistant.

The determination of various mechanical properties of high-temperature oxide scales has been of interest for many years. Applicable methods by which this can be done include traditional microhardness testing, ${ }^{5}$ frequency damping measurements of elastic properties, ${ }^{6}$ and acoustic emission detection of scale cracking. ${ }^{7,8}$ Recently, it has been shown that depth-sensing submicron indentation testing can be used to determine both plastic and elastic properties of oxide scales and that such an approach can be applied to surface products that are too sparse or thin for more typical techniques. ${ }^{9,10}$ Results from such work can be used as partial input to calculations of fracture toughness ${ }^{3}$ and to help establish spallation conditions for different scales ${ }^{24,11}$ as a function of alloy composition.

As with any hardness technique, there are both drawbacks and advantages to submicron indentation testing for mechanical properties determinations. When applied to oxide scales, more concerns arise, not the least of which is the relevance of room temperature measurements for scales whose performance is judged at elevated temperature. 5,10 Wood and 
Hodgkiess ${ }^{5}$ address many of these issues in an excellent manner and their arguments will not be repeated here. However, it is important to note that many of the advantages cited for hardness measurements of oxide scales are even more compelling in view of the recent availability of the means to conduct depth-sensing indentation testing on a submicron scale. The present paper reports data for chromia and alumina obtained by a depth-sensing submicron indentation technique with an emphasis on the development of methodologies for specific application to the measurement of mechanical properties of thin oxide scales.

A mechanical properties microprobe (MPM) was used to measure the hardness and Young's modulus of scales and bulk oxides by depth-sensing submicron indentation testing. Such techniques have been successfully applied to thin films on substrates as well as to bulk solids. ${ }^{12,13}$ In the MPM, an indenter is forced into the surface of a specimen (via magnetic coupling) while its displacement is measured by a capacitance gage. The smallest loading increment is approximately $0.3 \mu \mathrm{N}$ (with a maximum load of $120 \mathrm{mN}$ ), and the displacement resolution is less than $1 \mathrm{~nm}$. A light microscope is used to determine the area over which to place indentations, and indenter movements in all three dimensions are controlled by a computer, which is also used for data acquisition and analysis. Load versus displacement is continually monitored during an indentation event and, from this data, hardness, elastic modulus, and plastic depth can be determined as described elsewhere. ${ }^{10,12,13}$ A Berkovitch (three-faced) type of diamond indenter was used. For the penetration depths used in this study (125 to $200 \mathrm{~nm}$ ), the lateral dimensions of an indentation were on the order of $1 \mu \mathrm{m}$.

Two approaches were used to obtain indentation results from thin scales grown on metallic materials. In one method, an oxidized specimen was cut and polished in cross section. Attempts were then made to land the indenter into the scale. Because protective surface oxides are of primary interest, and, by nature, such layers are normally rather thin, it was difficult to assure indentation into the actual scales despite the small dimensions of the indenter (principally due to thermal drift). Consequently, for a typical cross section, many indentations targeted for the scale landed in the underlying alloy substrate or the mounting material. However, when this procedure was successful, quite reasonable values for scale hardness and modulus were found, ${ }^{9,10}$ and concerns about the influence of the substrate on the measurement of scale properties ${ }^{13,14}$ (apart from strain effects) are minimized. Another approach to scale measurements avoids the problem of limited target area by indenting from the top down (i.e., in the direction normal to the principal growth dimension of the scale). However, the depth sensitivity of the MPM requires relatively smooth surfaces on which to 
indent (so the instrument can accurately define the surface plane and the indenter can clear any asperities) and, often times, oxides scales can be of sufficient roughness to render the submicron indentation process inoperable. Nevertheless, several specimens of this type were analyzed in the present study and a fraction of them yielded acceptable results as described below.

B sth alumina-rich and chromia scales were studied. For the former, a binary iron aluminide (28 at. \% Al) was oxidized in air at $900^{\circ} \mathrm{C}$ for $168 \mathrm{~h}$. The specimen was then sectioned, polished, and indented in cross section. The chromia scales were formed on pure chromium by air oxidation at either 850 or $950^{\circ} \mathrm{C}$. They were then indented from the top down as described above. Because it is important to verify the validity of the MPM measurements of scale hardnesses and moduli, and to determine whether these properties might differ from those of their respective bulk oxides, alumina and chromia ceramics were also characterized using submicron indentation testing. These measurements were made on polished specimens of pure, polycrystalline $\mathrm{Al}_{2} \mathrm{O}_{3}$, c-axis sapphire and sintered chromia.

In the present experiments, placing the diamond indenter squarely in the polished cross section of a scale grown on $\mathrm{Fe}_{3} \mathrm{Al}$ was only infrequently successful. This was due not only to the thinness of the oxide, but also to the lack of any detectable corrosion product on much of the surface because of inhomogeneous nucleation and growth, or loss of the scale during cooling and/or subsequent preparation for indentation. As shown in Fig. 2.3-1, successful indentations were clearly distinguishable from those in the alloy substrate or in the mounting material by their greater load at a given displacement and the greater elastic component of the total deformation (as indicated by the displacement-axis intercept of the extrapolated initial unloading curve $\left.{ }^{10}\right)$. Thirteen indentations yielded load-displacement curves like that shown in Fig. 2.3-1(a) and gave values of $25 \pm 5$ and $290 \pm 36 \mathrm{GPa}$, respectively, for the average hardness at maximum load $(\mathrm{H})$ and Young's modulus $(\mathrm{E})$, as determined from the slope of the initial unloading curve. ${ }^{13}$ Table 2.3-1 compares these results to similar measurements on bulk alumina specimens and unoxidized $\mathrm{Fe}_{3} \mathrm{Al}$. The hardness of the scale on the iron aluminide was considerably higher than that for the alloy and its load-displacement curves resembled those of the bulk oxide (Fig. 2.3-1). However, in most cases, the hardness and modulus of the scale on the iron aluminide were lower than those measured for the bulk form of alumina.

Results on the hardness and modulus of chromia-rich scales from indentations made on polished cross sections of oxidized stainless steel have been reported previously. ${ }^{10}$ In the 
present study, the MPM was used on scales grown on pure chromium utilizing the top-down approach described above. While the problems associated with identifying and indenting a thin scale in cross section were eliminated, the number of successful indentations obtained in this case was limited by the roughness of the subject scales. Nevertheless, a sufficient number of acceptable load-displacement curves (six) was obtained for a scale grown on pure chromium (oxidized at $850^{\circ} \mathrm{C}$ ) to yield average values of hardness and Young's modulus of $22 \pm 7$ and $404 \pm 91 \mathrm{GPa}$, respectively. Six indentations on a second chromium specimen oxidized at $950^{\circ} \mathrm{C}$ gave averages of $\mathrm{H}=18 \pm 6$ and $\mathrm{E}=320 \pm 81 \mathrm{GPa}$. For comparison, MPM characterization of a polished and sintered $\mathrm{Cr}_{2} \mathrm{O}_{3}$ product yielded an average hardness of $29 \pm 2 \mathrm{GPa}$ and a Young's modulus of $316 \pm 24 \mathrm{GPa}$.

Hardness and Young's modulus are key parameters that have been applied to predicting the mechanical behavior of oxide scales (see, for example, Refs. 2-4, 11). Calculations of the critical strain for cracking, the temperature differential threshold for spallation, the fracture toughness parameter $\mathrm{K}_{\mathrm{IC}}$, and scale thickness limits for oxide yielding require knowledge of these properties (as well as others). If an understanding of the effects of changes in oxidation and alloy conditions on scale behavior is desired, self-consistent, sensitive measurements of hardness and modulus are more important than absolute accuracy. Good precision is therefore vital. Nevertheless, measurements that also yield confirmatory numbers for hardness and modulus increase confidence in the use of the MPM for mechanical characterization of oxide scales. Initial indications of the appropriateness of this submicron indentation method have previously been reported; ${ }^{9}$ the elastic modulus of chromia-rich scales on stainless steel closely matched literature data for bulk chromia. The present results again show that the MPM approach yields hardnesses and moduli for scales and bulk oxides that appear reasonable in light of data obtained by other methods, as shown in Tables 2.3-2 and 2.3-3. The agreement is quite good in view of all the possible factors (surface preparation, impurities, crystallographic effects, etc.) that can contribute to variations in hardness and modulus ${ }^{15}$ since such parameters were not controlled in all cases. Furthermore, hardness is not a well defined material property, and reported values can vary significantly depending on the particular measurement method used to generate the data. Despite this, the MPM always yielded values of scale hardness consistent with those for bulk ceramics like chromia and alumina (as opposed to metals and softer oxides). The good precision of the measurements is evident from the generally small standard deviations among indents in the same specimen. 


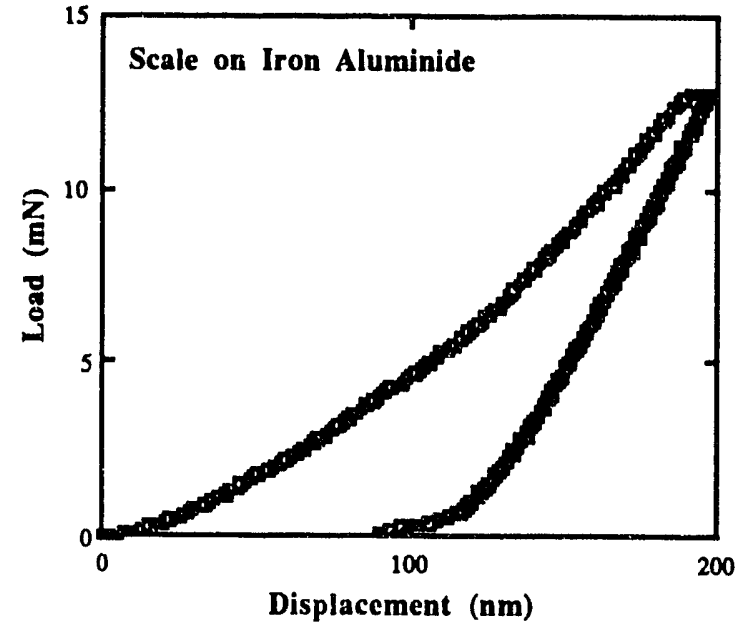

(a)

ORNL-DWG 91-9723

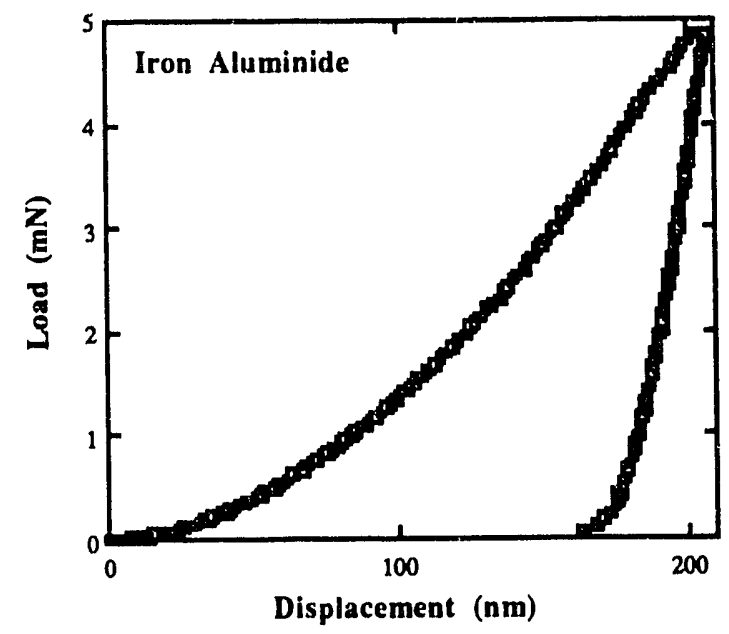

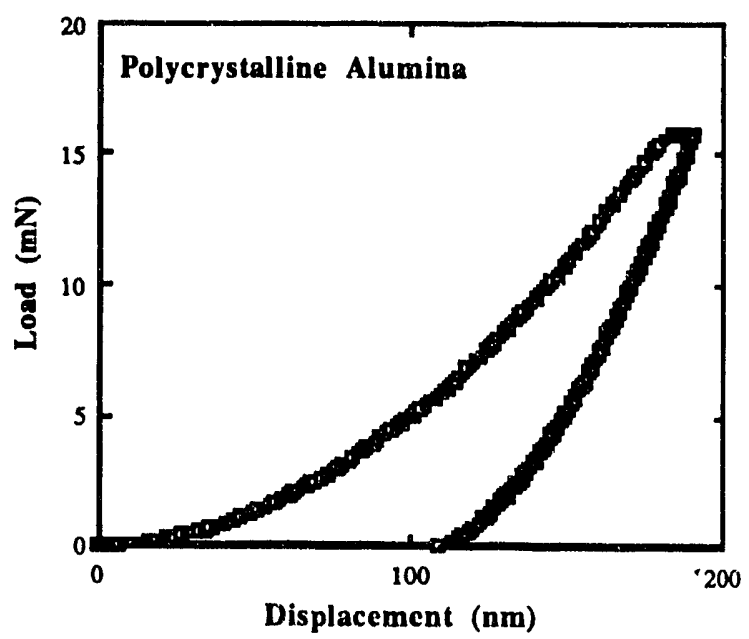

(b)
Fig. 2.3-1. Load versus displacement for: (a) scale grown on $\mathrm{Fe}_{3} \mathrm{Al}$, (b) bulk alumina, and (c) unoxidized $\mathrm{Fe}_{3} \mathrm{Al}$.

(c)

While, in general, the MPM data did fall within the range of values expected for oxides of the respective types, there were some exceptions. For the scales, some deviation from established values can be explained on the basis of substrate effects and surface oxide composition and these factors will be discussed below. In addition, there is a significant variation among the moduli for the four polycrystalline specimens of bulk alumina, and several of these values, as well as the measured moduli and hardnesses of the sapphire, are higher than what is reported in the literature (see Table 2.3-2). It is known that MPM unloading measurements can yield moduli that are higher than expected for harder materials like those in this study, ${ }^{13}$ but such a finding does not explain the difference between the MPM sapphire data of Oliver et al. ${ }^{16}$ and 
Table 2.3-1. Hardness (H) and Young's modulus (E) for alumina and $\mathrm{Fe}_{3} \mathrm{Al}$ as measured using the MPM

\begin{tabular}{lccc}
\hline \multicolumn{1}{c}{ Type } & $\mathrm{H}$ & $\mathrm{E}$ & $\mathrm{H} / \mathrm{E}$ \\
& $(6 \mathrm{~Pa})$ & $6(\mathrm{~Pa})$ & $\left(\mathrm{X} 10^{2}\right)$ \\
\hline Scale formed on $\mathrm{Fe}_{3} \mathrm{Al}$ oxidation at $900^{\circ} \mathrm{C}$ & $25 \pm 5$ & $290 \pm 36$ & $8.5 \pm 1.5$ \\
& & & \\
Bulk polycrystalline $\mathrm{Al}_{2} \mathrm{O}_{3}$ & $32 \pm 3$ & $424 \pm 28$ & $6.5 \pm 0.4$ \\
& $32 \pm 4$ & $482 \pm 50$ & $6.5 \pm 0.4$ \\
& $34 \pm 4$ & $463 \pm 27$ & $7.3 \pm 0.4$ \\
Bulk sapphire & $36 \pm 4$ & $539 \pm 44$ & $6.7 \pm 0.3$ \\
& & & \\
& & & \\
Unoxidized $\mathrm{Fe}_{3} \mathrm{Al}$ & $40 \pm 2$ & $553 \pm 7$ & $7.2 \pm 0.3$ \\
& $40 \pm 3$ & $557 \pm 2$ & $7.2 \pm 0.3$ \\
\end{tabular}

Table 2.3-2. Comparison of MPM data for alumina with results from literature

\begin{tabular}{|c|c|c|c|c|}
\hline \multirow{2}{*}{ Approach } & \multicolumn{2}{|c|}{ Scale } & \multicolumn{2}{|c|}{ Bulk oxide } \\
\hline & $\mathrm{H}(\mathrm{GPa})$ & $\mathrm{E}(\mathrm{GPa})$ & $\mathrm{H}(\mathrm{GPa})$ & $\mathrm{E}(\mathrm{GPa})$ \\
\hline MPM - this study & 25 & 290 & $32-36$ & $425-540$ \\
\hline $\begin{array}{l}\mathrm{MPM} \text { - alumina on } \\
\mathrm{Fe}-36 \text { at. \& } \mathrm{Al}^{10}\end{array}$ & 29 & 261 & - & - \\
\hline $\begin{array}{l}\text { Microhardness - alumina on } \\
\mathrm{Fe}-\mathrm{Cr}-\mathrm{Al}{ }^{5}\end{array}$ & 22 & - & - & - \\
\hline MPM-c-axis sapphire ${ }^{16}$ & - & - & 30 & 400 \\
\hline $\begin{array}{l}\text { Robertson \& Manning } \\
\text { estimates form literature }{ }^{4}\end{array}$ & 20 & - & - & 400 \\
\hline McColm survey ${ }^{15}$ & - & - & $19-23$ & 406 \\
\hline
\end{tabular}


the present modulus measurements (Table 2.3-2). Rather, the differences here more likely arise from the use of different diamond indenters or other instrument changes. ${ }^{17}$ However, if the $\mathrm{Al}_{2} \mathrm{O}_{3}$ data are considered in terms of the ratio of hardness to modulus $(\mathrm{H} / \mathrm{E})$ the scatter among the measurements is reduced considerably (see Table 2.3-1) and there is good agreement between the present results for sapphire and those of Oliver et al. ${ }^{16}$ (see Table 2.3-4). This ratio can be considered to be an indicator of the plasticity of the oxide ${ }^{15}$ (where plasticity increases as the ratio decreases) and should be a constant for a particular material. It should be noted that the MPM yields a H/E ratio for alumina that, in most cases, is significantly higher than those obtained from literature data obtained by other methods. ${ }^{4,15}$ However, as discussed above, it is most important that the MPM measurements yield self-consistent measurements, and the H/E results shown in Table 15 indicate that this, indeed, is the case if the MPM data are referenced to an invariant.

Extrapolation of the initial unloading curve to zero load allows determination of the plastic depth of an indentation (see Fig 2.3-1). ${ }^{13}$ Such information can be used to assess plasticity (nonrecoverable deformation) caused by forcing the indenter into the oxide to a selected depth. As shown above, a plasticity parameter $(\mathrm{H} / \mathrm{E})$ was helpful in evaluating variations in MPM data and it is, thus of, interest to examine the direct measurements of plastic depth for selected specimens. Such results are shown in Table 2.3-4 as a ratio of plastic depth to total indentation displacement. This indicator (which increases with increasing plasticity) was essentially the same for all the polycrystalline alumina and sapphire specimens despite the significant variations in modulus among them, and it was more constant than the $\mathrm{H} / \mathrm{E}$ values. While these measurements can be of value in judging differences between different oxides examined with the MPM, they, unlike H/E, cannot be directly compared to data from other investigations.

Although the MPM measurements associated with the bulk forms of alumina and chromia are important for verifying the MPM technique and for providing baseline data, the mechanical properties of scales based on these oxides are of principal interest in this line of investigation. The work to date has demonstrated the difficulties associated with trying to extract reliable information from very thin surface corrosion products that can be cracked, inhomogeneous, convoluted, and/or detached from the metallic substrate. However, given the small sampling volume of the MPM indenter, the present technique is appropriate for such attempts and, when indentations are made in sound scale material (as judged solely by the 
Table 2.3-3. Comparison of MPM data for chromia with results from literature

\begin{tabular}{lcccc}
\hline \multirow{2}{*}{ Approach } & \multicolumn{2}{c}{ Scale } & \multicolumn{2}{c}{ Bulk oxide } \\
\cline { 2 - 5 } & $\mathrm{H}(\mathrm{GPa})$ & $\mathrm{E}(\mathrm{GPa})$ & $\mathrm{H}(\mathrm{GPa})$ & $\mathrm{E}(\mathrm{GPa})$ \\
\hline MPM - this study & 22,18 & 404,320 & 29 & 298 \\
MPM - chromia on steel ${ }^{10}$ & 23,25 & 280,296 & - & - \\
Microhardness - chromia on & $18-33$ & - & - & - \\
Fe-Cr alloys & & - & - & 280 \\
Robertson \& Manning & & & & \\
estimates from 1iterature & & & & \\
\hline
\end{tabular}

Table 2.3-4. Comparison of plasticity parameters for bulk alumina as measured by the MPM and other methods

\begin{tabular}{ccc}
\hline \multicolumn{1}{c}{ Approach } & $\mathrm{H} / \mathrm{E}$ & $\mathrm{PD} / \mathrm{ID}^{\mathrm{a}}$ \\
\hline MPM - this study - polycrystalline $\mathrm{Al}_{2} \mathrm{O}_{3}$ & 0.066 & 0.71 \\
& 0.073 & 0.72 \\
& 0.075 & 0.70 \\
Sapphire & 0.065 & 0.70 \\
& 0.072 & 0.69 \\
MPM - c-axis sapphire & 0.073 & 0.70 \\
Robertson \& Manning survey & 0.075 & - \\
McColm survey & 0.050 & - \\
\hline
\end{tabular}

${ }^{a}$ Ratio of plastic to total indentation depth; all standard deviations were 0.01 . 
appearance of the load-displacement curves $^{9,10}$ ), reasonable hardness and modulus data have been generated as can be seen from the present results and those reported previously. ${ }^{10}$ The use of top-down indentations on as-grown scales avoids problems associated with having to place the indenter in a very thin layer in cross section, but, as described above, surface roughness can be a major hindrance. (In both cases, defects and porosity in the oxide scale can also lead to unsatisfactory results.) Careful top-down polishing of an as-oxidized surface can decrease the problems related to surface roughness, and, the utility of such an approach is currently being evaluated.

As shown in Tables 2.3-2 and 2.3-3, the MPM hardness data for the scales show good agreement with the limited results obtained by more traditional microhardness measurements (on somewhat thicker products). ${ }^{4,5}$ For both chromia and alumina, the scale hardness values were less than those measured with the MPM for the corresponding bulk oxides although there is some overlap in certain cases based on the standard deviations. Scale hardness was always much closer to that of the bulk oxide than that of the underlying substrate. In top-down indentations, the softer metal substrate can influence the measurement of hardness if the total displacement is more than about $25 \%$ of the thickness of the scale. ${ }^{14}$ For the chromia scales (about 500 to $700 \mathrm{~nm}$ in thickness), the indenter at maximum displacement $(200 \mathrm{~nm})$ exceeded this limit and it is, therefore, not surprising to measure lower hardness values than what is expected from bulk chromia measurements. However, the MPM allows measurement of the hardness as a function of displacement, ${ }^{13}$ and the average hardness of the chromia scale did not change between 50 and $200 \mathrm{~nm}$. Thus, no substrate influence could be confirmed. Moreover, the measurement of Young's modulus is even more sensitive to the presence of the substrate ${ }^{13,14}$ and, as seen in Table 2.3-3, the measured scale moduli are equal to or greater than what is expected for chromia rather than being closer to that of the substrate (see Table 2.3-2). On the other hand, the $\mathrm{H} / \mathrm{E}$ values for the chromia scales $(0.055,0.058)$ are certainly not characteristic of the bulk oxide $(0.091)$. A greater number of successful top-down indentations is needed to determine whether there is an appreciable substrate effect, and such work is now under way.

In contrast to the results for the chromia scale, the data for oxidized $\mathrm{Fe}_{3} \mathrm{Al}$ were obtained from a polished cross section. In this way, substrate properties were mostly avoided, but the limited target area and edge effects can be problematical. As with the chromia scale, the hardness of the surface product tended to be less than for the bulk aluminum oxide. This 
can be expected because, unlike the oxide grown on an unalloyed metal (as in the case of the chromia scale discussed above), there is a definite possibility of the presence of a second oxide in the scale. For the $\mathrm{Fe}_{3} \mathrm{Al}$, the exact composition of the oxide scale has not been determined, but other work ${ }^{5}$ suggests that iron oxides could exist either separately as $\mathrm{Fe}_{2} \mathrm{O}_{3}$ or as a reaction product with alumina $\left(\mathrm{FeO} \bullet \mathrm{Al}_{2} \mathrm{O}_{3}\right)$. In this case, the overall hardness should be less than that of pure $\mathrm{Al}_{2} \mathrm{O}_{3}$. (The hardness of $\mathrm{Fe}_{2} \mathrm{O}_{3}$ is substantially lower than that of alumina. ${ }^{4,5}$ ). This effect of the mixing of a softer oxide with a harder one may explain the slightly higher hardness of the scale formed on an iron aluminide containing less iron $^{10}$ (Fe-36 at. \% $\mathrm{Al}$; see Table 2.3-2) and the lower hardness of chromia-rich scales on stainless steel ${ }^{10}$ relative to the present measurement for bulk chromia (Table 2.3-3). In the same manner, Woods and Hodgkiess $^{5}$ reported that the scales on $\mathrm{Fe}-70 \mathrm{Cr}$ and $\mathrm{Fe}-40 \mathrm{Cr}$ (wt \%) were slightly harder than that on $\mathrm{Fe}-28 \mathrm{Cr}$ but, as in the present circumstances, the differences were not great and could not be rigorously deduced because of experimental uncertainty.

A major issue being addressed by this work relates to the extent to which the mechanical properties of scales can be described from knowledge of their corresponding bulk oxides. Notwithstanding the fact that, in certain ways, measurement on scales may be easier than testing bulk ceramics, ${ }^{5}$ it is important to determine whether the data base for oxides can be exploited to predict scale behavior. Robertson and Manning ${ }^{4}$ opted to use values of Young's modulus, surface fracture energy, and yield stress (hardness) derived principally from bulk oxide data (modified to account for porosity and microstructure) in their calculations of scale fracture conditions because of concern with errors associated with measurements on scales. They argued that scale values of Young's modulus should be similar or slightly less than those of the corresponding bulk oxide. ${ }^{4}$ Although previous measurements for chromia-rich scales on stainless steel $(E=280 \text { to } 300 \mathrm{GPa})^{9}$ showed excellent agreement with the present MPM determination of $\mathrm{E}$ for bulk chromia $(316 \mathrm{GPa})$ and that from the literature (286 GPa), ${ }^{4}$ Table 2.3-1 shows that this is not necessarily the case for alumina formers and that their respective hardnesses are not always equivalent. Furthermore, the large uncertainty associated with the MPM measurements for chromia on chromium and its uncharacteristic (for this type of oxide) $\mathrm{H} / \mathrm{E}$ prevent a definitive conclusion regarding the relationship between bulk and scale properties of $\mathrm{Cr}_{2} \mathrm{O}_{3}$. However, if a comparison in terms of a parameter like $\mathrm{H} / \mathrm{E}^{15}$ is made, it appears that the scale data for alumina $(\mathrm{H} / \mathrm{E}=0.086)$ and for the chromia-rich scales on stainless steel ${ }^{10}(0.082,0.084)$ more closely resemble the elastic-plastic behavior of bulk 
alumina (0.066 to 0.075$)$ and chromia (0.091), respectively, than do the values of hardness and modulus. This may have importance in the prediction of oxide yielding. ${ }^{4}$

The present work indicates that the MPM can be used not only to obtain relative scale data but also to determine the conditions under which bulk data are adequate. In both cases, such results should be valuable in modeling the mechanical behavior of scales and predicting conditions under which their ability to protect the underlying metallic material is enhanced. Improvements in methodology and specimen preparation are being pursued in order to reduce experimental uncertainty and yield better properties resolution.

A mechanical properties microprobe (MPM) was used to measure hardness and Young's modulus of scales and bulk oxides by depth-sensing submicron indentation testing. Results for the scales and bulk ceramics were within the range of expected values based on data from other methods and, for the cases examined, were self-consistent with other MPM studies. The determinition of plasticity parameters appeared to be a good way of normalizing different sets of data. The hardness and modulus of the scales did not always match those of the corresponding bulk oxide. Some difficulties with top-down indentations on a pure chromia scale were encountered due to surface roughness and possible substrate effects. Indentations into polished cross sections of scales yielded more statistically rigorous data but presented a much smaller target for indenter placement. The experiments suggested improvements in the MPM methodology and specimen preparation that should reduce experimental uncertainty, increase the fraction of successful indentations, and yield better resolution of minor differences in properties. Depth-sensing submicron indentation testing appears to be a promising method to obtain relative data with which to formulate the best approaches to improved corrosion resistance of alloys by optimizing the mechanical properties of the protective oxide scale.

\subsubsection{References}

1. P. Hancock, Werkst. Korros. 21, 1002-6 (1970).

2. H. E. Evans and R. C. Lobb, Corros. Sci. 24, 209-22 (1984).

3. P. Hancock and J. R. Nicholls, Mater. Sci. Technol. 4, 398-406 (1988).

4. J. Robertson and M. I. Manning, Mater. Sci. Technol. 6, 81-91 (1990).

5. G. C. Wood and T. Hodgkiess, Werkst. Korros. 23, 766-773 (1972).

6. D. Bruce and P. Hancock, J. Inst. Met. 97, 140-48 (1969). 
7. M. J. Bennett, A. C. Roberts, M. W. Spindler, and D. H. Wells, Interaction Between Oxidation and Mechanical Properties of 20Cr/25Ni/Nb Stabilised Stainless Steel, AERE R 13685, UKAEA Harwell Laboratory report, December 1989.

8. L. Tiefan and L. Meishuan, Mater. Sci. Eng. A120, 239-44 (1989).

9. P. F. Tortorelli, J. R. Keiser, K. R. Willson, and W. C. Oliver, "Effects of Reactive Elements on Oxide Scale Deformation and Cracking Based on Submicron Indentation Testing," pp. 271-77 in Microscopy of Oxidation, ed. M. J. Bennett and G. W. Lorimer, The Institute of Metals, London, 1991.

10. P. F. Tortorelli, J. R. Keiser, K. R. Willson, and W. C. Oliver, "Initial Determination of the Micromechanical Properties of Oxide Scales," pp. 463-74 in Proceedings of the Fourth Annual Conference Fossil Energy Materials, ORNL/FMP-90/1, CONF-900546, Oak Ridge Natl. Lab., August 1990.

11. H. E. Evans, Mater. Sci. Eng. A120, 139-46 (1989).

12. J. B. Pethica, R. Hutchings, and W. C. Oliver, Phil. Mag. A 48, 593-606 (1983).

13. W. D. Nix, Metall. Trans. A 20A, 2217-45 (1989).

14. C. J. McHargue, "Indentation Testing of Thin Films and Hard Materials," in Diamond and Diamond-Like Films and Coatings, ed. R. E. Clausing, L. L. Horton, J. C. Angus, and P. Koidl, North Atlantic Treaty Organization-Advanced Study Institute Series B: Physics, Vol. 266, Plenum Press, New York, 1991.

15. I. J. McColm, Ceramic Hardness, Plenum Press, New York, 1990.

16. W. C. Oliver, C. J. McHargue, and S. J. Zinkle, Thin Solid Films 153, 185-96 (1987).

17. M. E. O’Hern, Nano Instruments, Inc., Knoxville, Tennessee, personal communication, May 1991.

\subsubsection{Erosion Studies on a $\mathrm{Fe}_{3} \mathrm{Al}$-Based Iron Aluminide and $1100 \mathrm{Al}$ - Mukund Rao and James Keiser}

Samples of $\mathrm{F} \mathrm{Fe}_{3} \mathrm{Al}$-based iron aluminide alloy were eroded using nominally spherical steel shot. Two distinct erosion mechanisms were observed: (1) extrusion of platelets resulting from spherical particle impacts and (2) cutting of the target by angular particles either present in the initial erodent or formed on impact by fracture of the shot. The overall erosion resistance of the alloy was judged to be relatively good and may be improved by increasing the alloy's ductility. 
Measurements using a mechanical properties microprobe (MPM) showed that significant work hardening occurred due to erosion, but the hardness dropped off near the surface, apparently due to thermal effects. In contrast no sub-surface softening was observed in samples of $1100 \mathrm{Al}$ which were also eroded by steel shot.

In order to model the impact process, single $343 \mu \mathrm{m}$ WC spheres were shot at the two alloys at velocities between $20 \mathrm{~m} / \mathrm{s}$ and $900 \mathrm{~m} / \mathrm{s}$. Compared to the iron aluminide, the craters on $1100 \mathrm{Al}$ show better developed lips and features indicative of sustained plastic deformation. Both alloys showed thermally induced subsurface softening at high velocities. At lower velocities, only the iron aluminide showed clear thermal effects.

Results of the single particle and multiple particle impact tests are reconciled in terms of deformation behavior and thermal effects.

Intermetallic iron aluminide alloys based on ordered $\mathrm{Fe}_{3} \mathrm{Al}$ retain their strength to $600^{\circ} \mathrm{C}$ while exhibiting good elevated temperature oxidation and sulfidation resistance..$^{1-4}$ Although they are potentially low cost alternatives to many high temperature nickel-based alloys and stainless steels, commercialization has been hindered by their low ductility at room temperature. Recently, however, ductility limits have been raised significantly by careful alloying additions and heat treatments and there has been increasing interest in the alloys for applications in advanced fossil energy conversion systems such as coal gasification. ${ }^{3,4}$

Since materials used in fossil energy systems are expected to withstand damage both from hot corrosive gases as well as fine particulates in the gas stream, erosion-corrosion behavior is of prime importance. The present study provides a first step towards this understanding by examining the room temperature solid particle erosion response of an $\mathrm{Fe}_{3} \mathrm{Al}$-based iron aluminide alloy. Results are compared with those from erosion studies on annealed $1100 \mathrm{Al}$ in order to further understand the effect of material properties on erosion in general.

The composition of the vacuum induction melted iron aluminide alloy was (in weight percent) $15.9 \mathrm{Al}-5.2 \mathrm{Cr}-1.0 \mathrm{Nb}-0.033 \mathrm{~B}-0.011 \mathrm{C}$-bal.Fe. The alloy was homogenized at $1150^{\circ} \mathrm{C}$ for $20 \mathrm{~h}$, hot forged at $1000^{\circ} \mathrm{C}$ and hot rolled at $800^{\circ} \mathrm{C}$. Following this, samples were annealed in air at $700^{\circ} \mathrm{C}$ for $1 \mathrm{~h}$ and quenched in mineral oil. Sample surfaces were polished on 600 grit $\mathrm{SiC}$ prior to erosion testing.

Multi-particle erosion tests were conducted at the University of Notre Dame using a rotating arm apparatus. ${ }^{5}$ The erodent was spherical steel shot with diameters from 
297-420 $\mu \mathrm{m}$. Room temperature erosion tests were conducted at impingernent angles of 30 , 60 , and $90^{\circ}$ to the specimen surfaces at a particle velocity of $45 \mathrm{~m} / \mathrm{s}$.

Single particle impact tests were conducted using two different gas guns - one attached to a scanning electron microscope (SEM) capable of firing balls in controlled environments at velocities between $10-60 \mathrm{~m} / \mathrm{s}$ and the other capable of firing particles in air at velocities between $200-2000 \mathrm{~m} / \mathrm{s}$. The two guns were used to fire single $343 \mu \mathrm{m}$ diameter WC spheres at impact angles of 30 and $90^{\circ}$ to the target surfaces at velocities up to $900 \mathrm{~m} / \mathrm{s}$ at room temperature.

Samples with single impact craters were sectioned normal to the impacted surface, whereas eroded samples were mounted in 3:1 tapered sections to accentuate surface features. All the sectioned samples were polished and lightly etched and a MPM was used to measure the hardness at various locations on the sectioned samples.

Conventional microhardness measurements using a Vickers indenter were made on the steel shot and on the iron aluminide samples. A wide range of hardnesses was measured on the shot, some of which were covered with a hard, friable oxide scale. It was estimated that less than $25 \%$ of the shot had a hardness greater than $310 \mathrm{HV}_{10}$, the average hardness of the iron aluminide sample surfaces prior to erosion.

Figure 2.3-2 shows specimen mass loss measurements made at various stages of erosion of the iron aluminide alloy. A threshold/incubation period is clearly seen for all three angles of incidence. To a first approximation, similar steady state erosion rates were observed for both 30 and $60^{\circ}$ incidence. For the $90^{\circ}$ tests, the total dose was insufficient to conclusively estimate a steady state erosion rate.

Figure 2.3-3 shows the appearance of the surfaces after erosion at 30 and $90^{\circ}$ incidence. A significant number of sharp gouges and cuts due to impacts of angular particles can be seen in both Figs. 2.3-3(a) and (b). At $30^{\circ}$ incidence, several instances of elliptical impact craters with thin protruding lips/flakes on one side clearly indicate the damage caused by the oblique impact of spherical particles. Impact damage attributable to spherical particles is difficult to identify for $90^{\circ}$ incidence. Specimens eroded at $60^{\circ}$ incidence were closer in appearance to surfaces eroded at $90^{\circ}$ than those eroded at $30^{\circ}$. This is not surprising in view of the large normal component of the incident velocity at $60^{\circ}$ incidence.

Individual impact craters due to rounded particles could be seen on specimens which had been subjected to very low doses of erodent. In Fig.2.3-4(a), both craters have thin lips of 
ORNL-DWG 91-9726

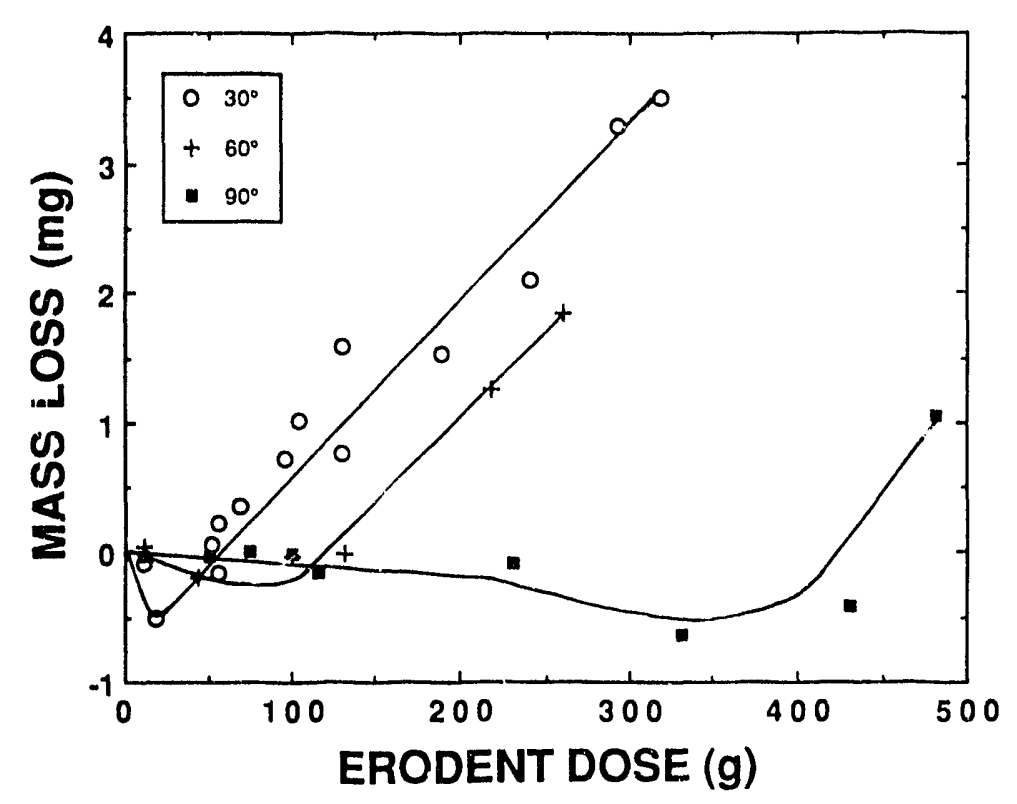

Fig. 2.3-2. Erosion test results for iron aluminide alloy.

extruded material in the impact direction. There are also networks of smaller lips/extrusions within the craters themselves. Figure 2.3-4(b) also shows two overlapping craters. However, in this case, there is little evidence of lip formation or material extrusion and significant material removal cannot be associated with the impacts. Craters of the type in Fig. 2.3-4(b) may be from impacts of relatively soft particles or due to particles diverted from the main stream and impacting at local incident angles near $90^{\circ}$.

An example of a crater due to the impact of a rounded particle at $90^{\circ}$ incidence is shown in Fig. 2.3-5. The clarity of the polishing grooves passing through the crater and the absence of lips or deformation on the crater edge show that there was little material movement in the crater on impact. This implies that the plastic zone associated with each impact does not reach the surface, making it difficult to create extruded platelets as seen at $30^{\circ}$ incidence. Even at the $11 \mathrm{~g}$ dose, portions of the specimen were covered with gouges and features more indicative of damage by irregularly shaped particles. Platelet formation and removal plays a smaller role in erosion at $90^{\circ}$ incidence than at $30^{\circ}$ incidence.

It is difficult to estimate the overall damage contributions by the two processes of material removal. Although more material is removed per event by cutting actions, most of the impacting particles are rounded. The extent of cutting may be increased significantly by fracture of the oxide scale present on some of the shot. Fracture may be more frequent for 

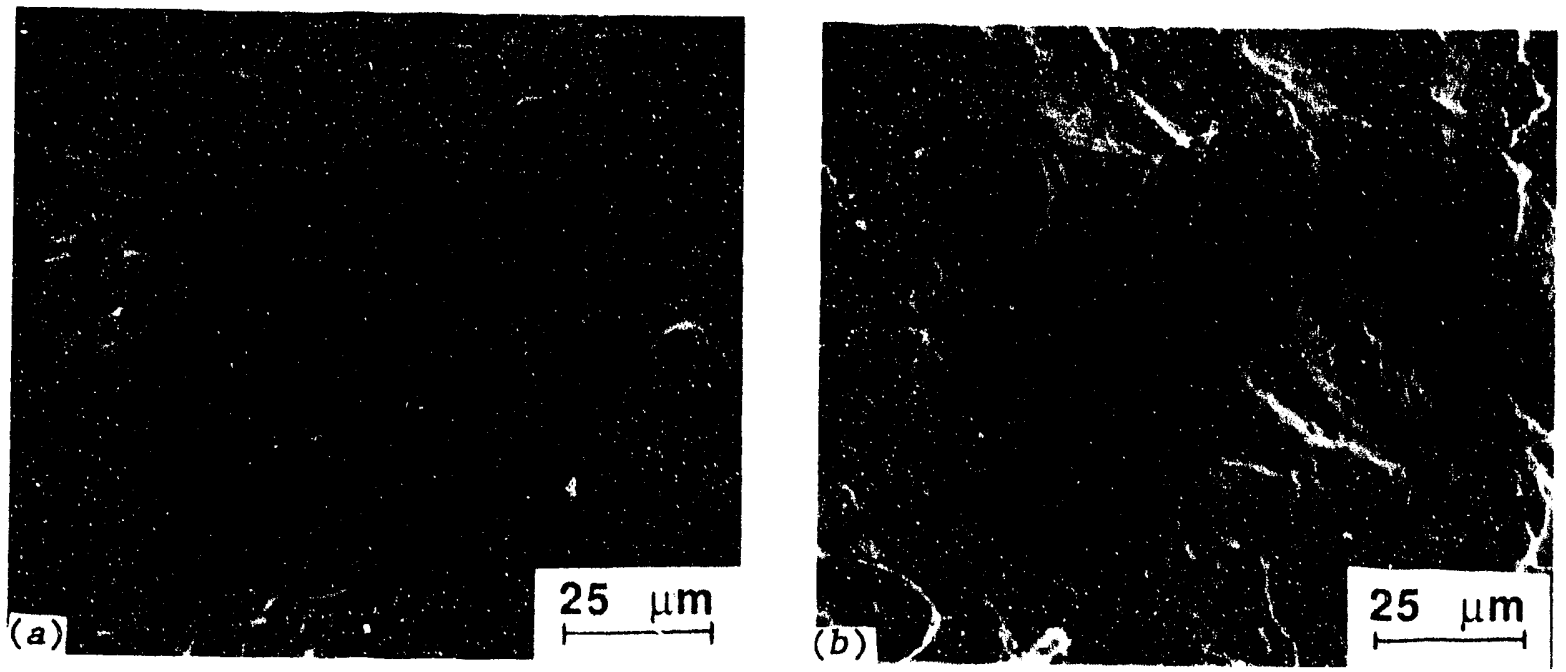

Fig. 2.3-3. Surfaces of iron aluminide samples after erosion at (a) $30^{\circ}$ incidence and (b) $90^{\circ}$ incidence.

M31896
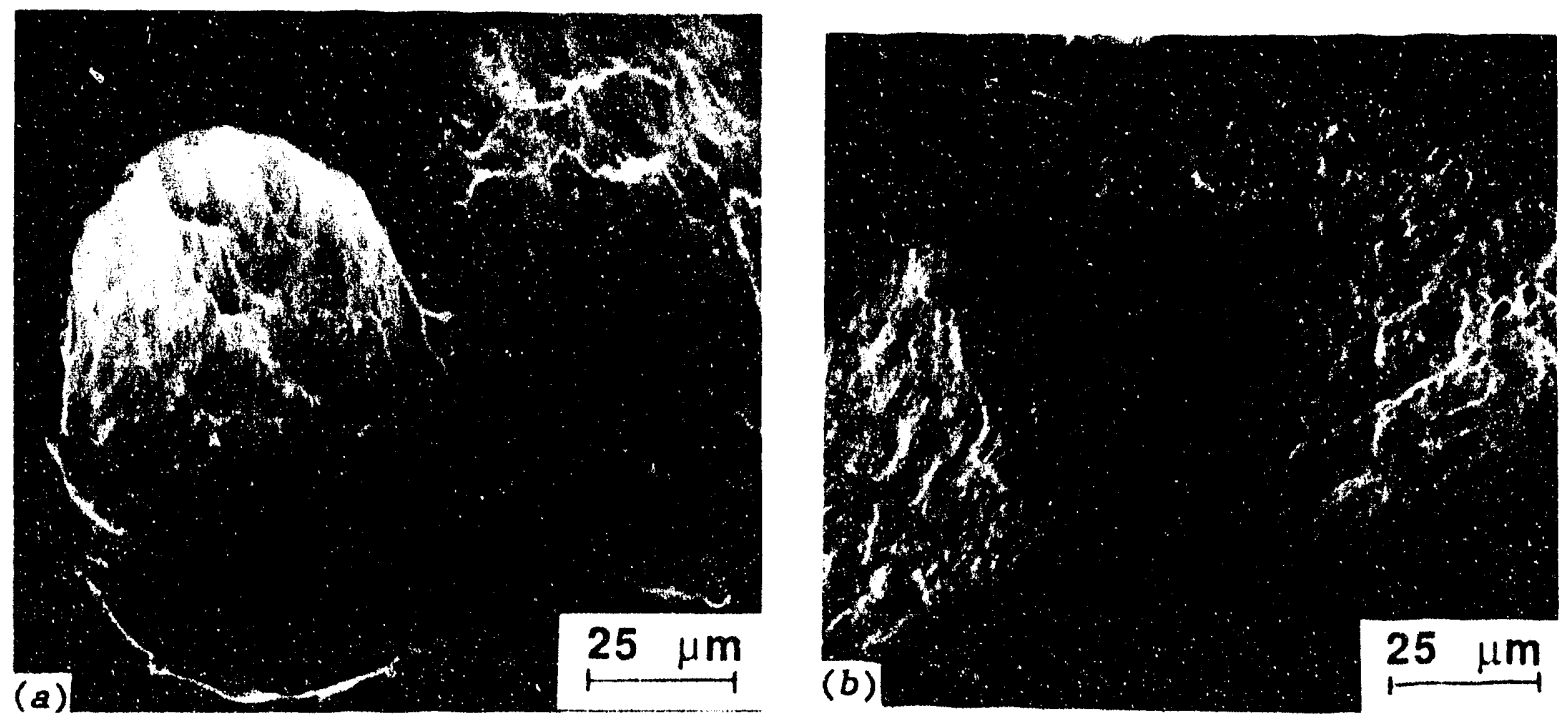

Fig. 2.3-4. Impact craters on iron aluminide sample eroded by $11 \mathrm{~g}$ of steel shot at $30^{\circ}$ incidence. 
M31901

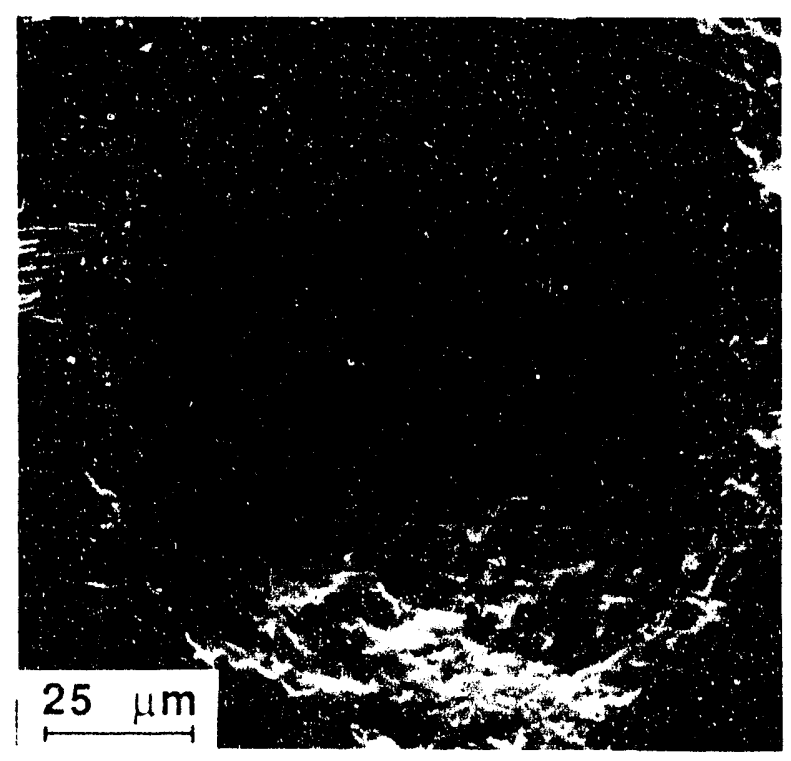

Fig. 2.3-5. Impact crater on iron aluminide sample eroded by $11 \mathrm{~g}$ of steel shot at $90^{\circ}$ incidence.

$90^{\circ}$ impacts, but impacts of angular particles at $30^{\circ}$ are more likely to produce debris in the form of a chip than an impact at $90^{\circ}$ which may create a deep gouge in the target. The combination and frequency of these events may lead to an overall balance in the erosion rates at the three incident angles. Most metallic alloys are expected to show 'ductile' behavior with erosion rates at a maximum around $30^{\circ}$ incidence angle as opposed to 'brittle' materials which have their highest erosion rates at $90^{\circ}$ incidence. ${ }^{6}$ However, erosion studies on steels (which are close in hardness and ductility to the present iron aluminide alloy) show mixed results. Depending on the erodent, heat treatments, and test conditions, maximum erosion rates have been observed at values of the incident impact angle covering the range from 30 to $90^{\circ} .^{7-10}$

Figure 2.3-6 shows the results of MPM measurements beneath surfaces eroded at $30^{\circ}$ and $90^{\circ}$ incidence. The hardness of the uneroded, bulk material has a value of 1 on a relative hardness scale. At both angles of incidence, significant work hardening occurs due to impact. A series of profiles from specimens exposed to steadily increasing doses of erodent showed that the thickness of the hardened layer beneath the surface increased with erodent dose (as strain built up beneath the eroded surface) and was greater under $90^{\circ}$ impact conditions than for erosion at $30^{\circ}$ (since a greater fraction of the incident energy is transferred to the target at 


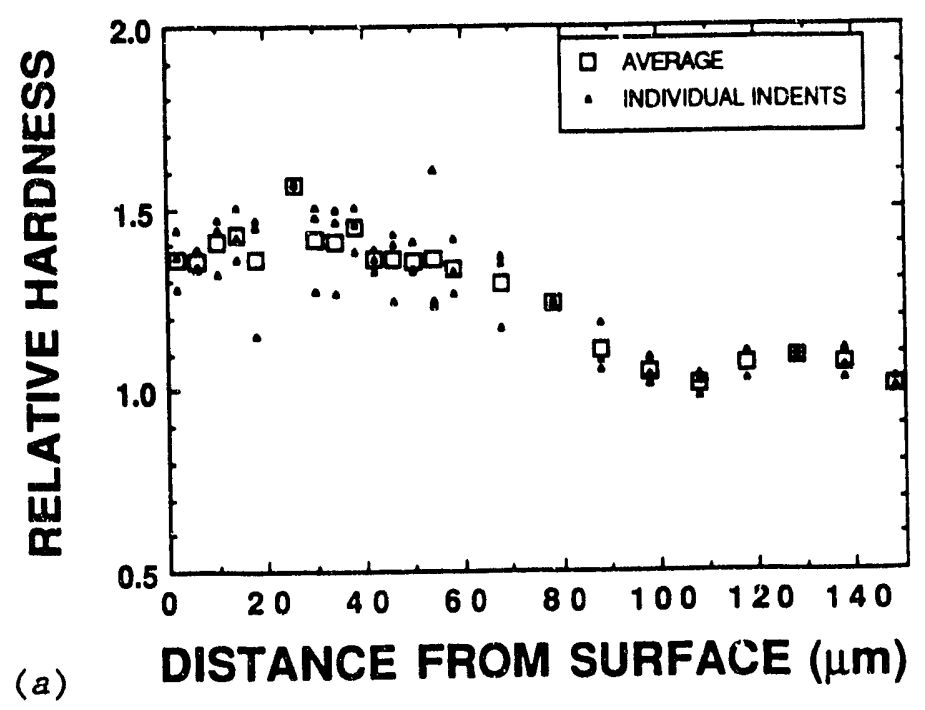

ORNL-DWG $91-9728$
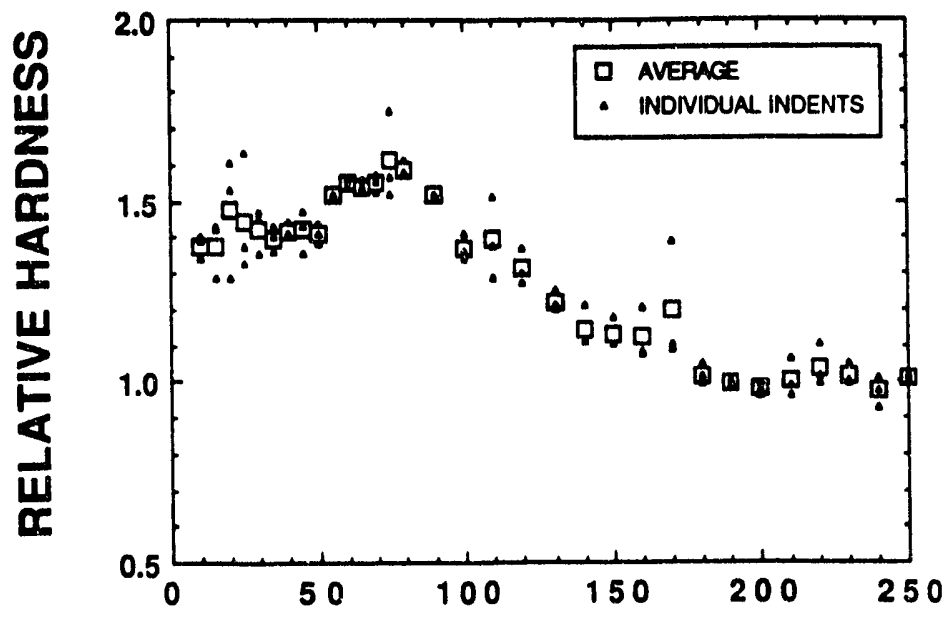

(b)

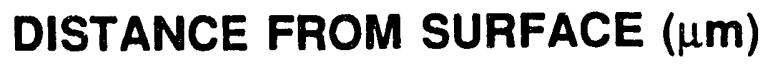

Fig. 2.3-6. MPM hardness profiles beneath surfaces of iron aluminide samples eroded at (a) $30^{\circ}$ incidence and (b) $90^{\circ}$ incidence.

$90^{\circ}$ incidence). Note, however, that the peak value of hardness is similar at both angles indicating that flow stress due to work hardening tends to increase and then saturate.

The most interesting feature of the MPM profiles is that the hardness drops off in near-surface regions. This is especially clear at higher doses and occurs more extensively at $90^{\circ}$ incidence. As has been reported previously, no near-surface softening was observed in 
annealed $1100 \mathrm{Al}$ eroded under similar conditions. ${ }^{11-13}$ In clear contrast to Fig. 2.3-6, typical MPM profiles on $1100 \mathrm{Al}$ showed a monotonically decreasing hardness with increasing distance from the eroded surface.

Since near-surface layers in the eroded iron aluminide are softer than regions farther away from the eroded surface, thermal effects may be playing a role. Typical estimates of the temperature rise during erosion depend on the thermal characteristics of the target material and its hardness under the impact conditions. ${ }^{14,15}$ Thermal effects may be expected to be more significant in low melting alloys. The present results therefore suggest that such effects may depend to a larger extent on mechanical properties of the alloy than previously thought.

Single particle impacts at $30^{\circ}$ incidence on 1100 aluminum and the iron aluminide alloy using $343 \mu \mathrm{m}$ diameter WC balls at velocities comparable to that in the multi-particle erosion tests formed similar craters. In both cases a small lip was formed as the particle exited the crater and, as expected, the crater was larger and the deformation more apparent in the softer aluminum alloy. At higher velocities, however, significant differences were apparent. At impact velocities of several hundred meters per second, (Fig. 2.3-7) there is severe extrusion and tearing of material and extensive deformation around the impact crater in 1100 aluminum.

M31236

M31242
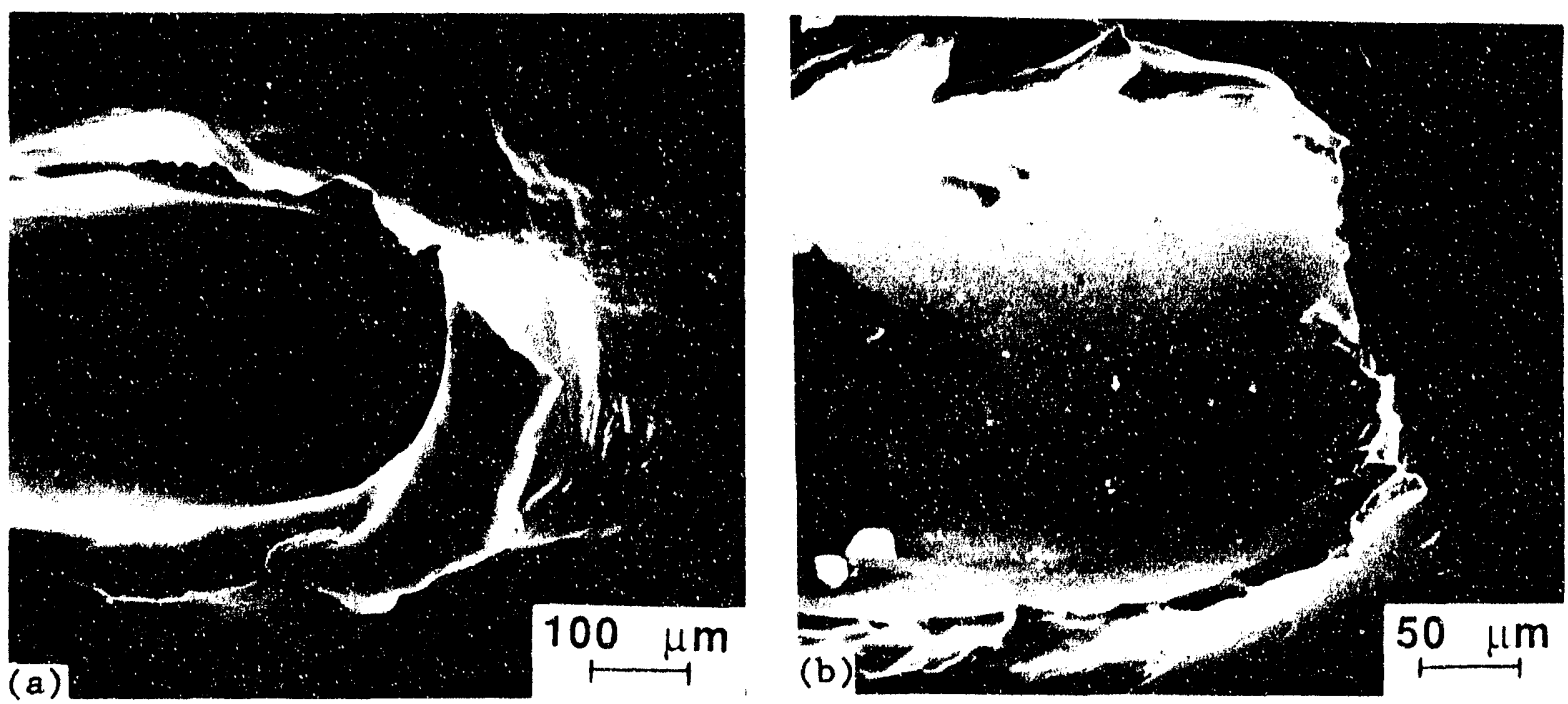

Fig. 2.3-7. Exit regions of craters formed by $343 \mu \mathrm{m}$ diameter WC balls impacting at $30^{\circ}$ incidence on (a) 1100 aluminum at $625 \mathrm{~m} / \mathrm{s}$ and (b) iron aluminide alloy at $450 \mathrm{~m} / \mathrm{s}$. Impact is from left to right. 
In contrast, the $\mathrm{Fe}_{3} \mathrm{Al}$-based alloy shows smaller lips and less deformation around the crater. Material extruded at the exit edge of the crater appears to have been completely removed, evidently due to its inability to accommodate the plastic strain associated with the impact. A similar conclusion was reached after comparing the surfaces of the two alloys after multi-particle erosion. During erosion at oblique incidence, ductile materials such as 1100 aluminum develop characteristic rippled surface structures, consisting of breaking wave crests and wave valleys, apparently involving material movement from wave valleys into wave crests. ${ }^{11,16}$ Such features did not form on the iron aluminide alloy.

MPM measurements beneath high-velocity single impact craters showed near-surface softening effects in both the materials, not surprising in view of the large energy inputs at these velocities. At low velocities, however, some differences exist. In Fig. 2.3-8(a), evidence of softening in the as-heat treated iron aluminide alloy is marginal. However, the softening clear occurs when a small amount of cold work is introduced in the alloy, as shown in Fig. 2.3-8(b). Similar measurements have not been made for $90^{\circ}$ impacts on cold worked 1100 $\mathrm{Al}$, but previous studies on single impacts at $30^{\circ}$ incidence indicated no near-surface softening. ${ }^{17}$

The results from the single impact tests suggest that in multi-particle erosion tests thermal effects may have been accentuated because plastic deformation tends to be localized in the iron aluminides. Thermal effects may be expected to be distributed evenly over large volumes in soft $1100 \mathrm{Al}$, since deformation is spread over a large volume and the material has very high dynamic recovery. In contrast thermal effects are likely to be localized in small volumes in high strength, low ductility, ordered structures such as the iron aluminide alloy. This is supported by the fact that restricting deformation by cold working the alloy accentuated the thermal effects during single impacts. Some additional support is provided by recent observations of subsurface softening due to single impacts on steels which had been previously eroded-corroded. ${ }^{18}$ The erosion-corrosion tests had been conducted at low velocities $(10-20 \mathrm{~m} / \mathrm{s})$ and resulted in slightly work-hardening the surface layers. If the type of behavior described here does occur, it may explain results which show that heat treatments and alloying additions have little effect on erosion resistance. ${ }^{8,10}$ Some of these studies considered thermal effects, but lacked direct evidence. ${ }^{15,19}$

The erosion resistance of the iron aluminide alloy is difficult to gauge from this study. However, comparison with results of studies of steels and cast irons eroded with various particles of comparable hardness ${ }^{19,20}$ indicates that the erosion resistance of iron aluminides 
may be comparable to that of materials they may replace. The elevated temperature strength of the alloy may contribute to its erosion resistance, in spite of the softening effects described above. In the present study, none of the eroded aluminides displayed cracks or delaminations suggesting catastrophic failure of the material. Thus the material had enough ductility to accommodate some amount of plastic strain. However, the limited extent of extrusion of lips and flakes suggests that erosion resistance would be improved if ductility could be further enhanced without sacrificing strength.

The erosion behavior of a $\mathrm{Fe}_{3} \mathrm{Al}$-based iron aluminide alloy by nominally spherical steel shot was examined. Two distinct erosion mechanisms were observed: extrusion and fracture of platelets by the impact of spherical particles and a cutting or gouging out of material by the impact of angular particles. Erosion rates were roughly similar at all angles of incidence, due to a complex balance of the extent of platelet formation and cutting at the various angles, with increased contributions from secondary erosion due to shattered erodent particles at $90^{\circ}$ but more efficient material removal by angular particles at $30^{\circ}$.

The aluminide work-hardened significantly under impact, and subsurface microhardness was higher than almost all the steel shot. The hardness dropped off in near-surface layers and platelets formed clearly by the impact of spherical particles were visible on the eroded surface, suggesting thermal effects during erosion. The amounts of work-hardened and thermally softened material were greater for erosion at $90^{\circ}$ because a greater fraction of the energy of impacting particles was transferred to the target. No subsurface softening was seen in eroded 1100 aluminum, and a small amount of cold work accentuated subsurface softening in the iron aluminide alloy subjected to single particle impacts, suggesting that thermal effects may be important in alloys where deformation tends to be localized over small volumes. Thermal effects may be complex in the iron aluminide alloy because of the alloy's unique elevated temperature mechanical properties.

Data from available literature showed that the aluminides may have an erosion resistance comparable to other engineering alloys, and the overall results indicate relatively good resistance of iron aluminides to solid particle erosion which may be improved by increasing the alloy's ductility. 


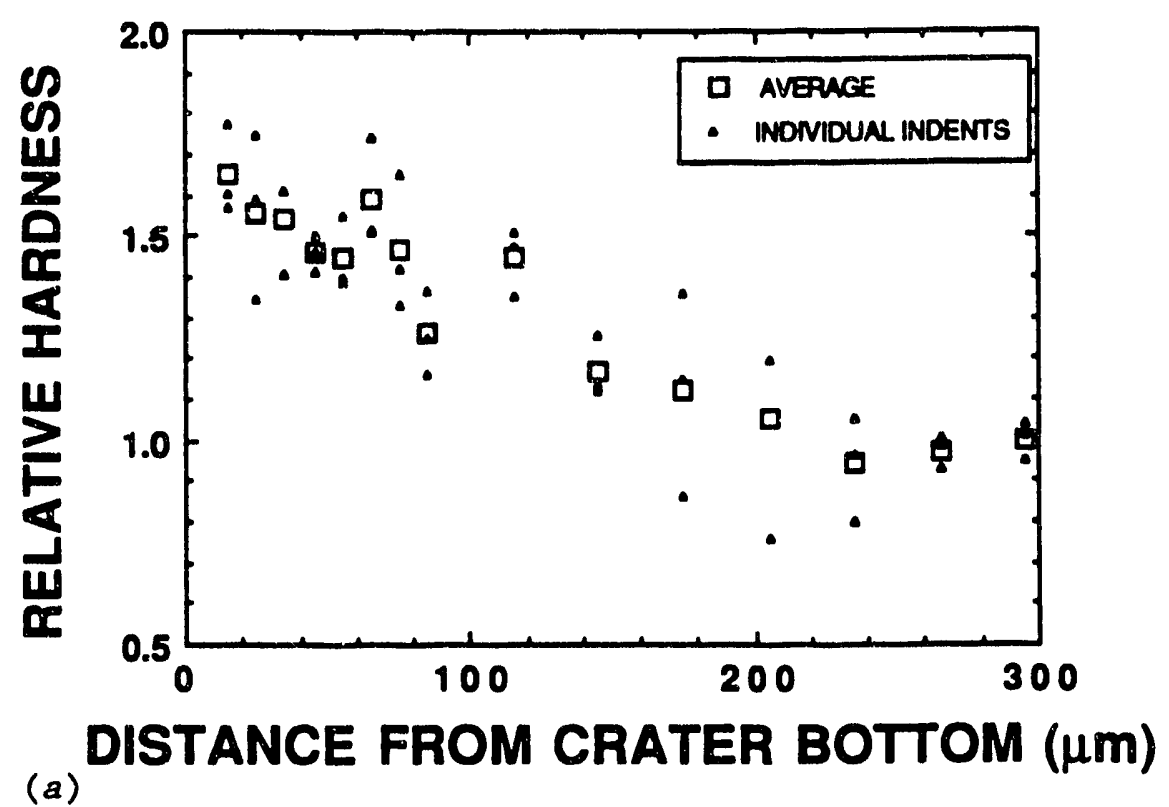

ORNL-DWG 91-9730

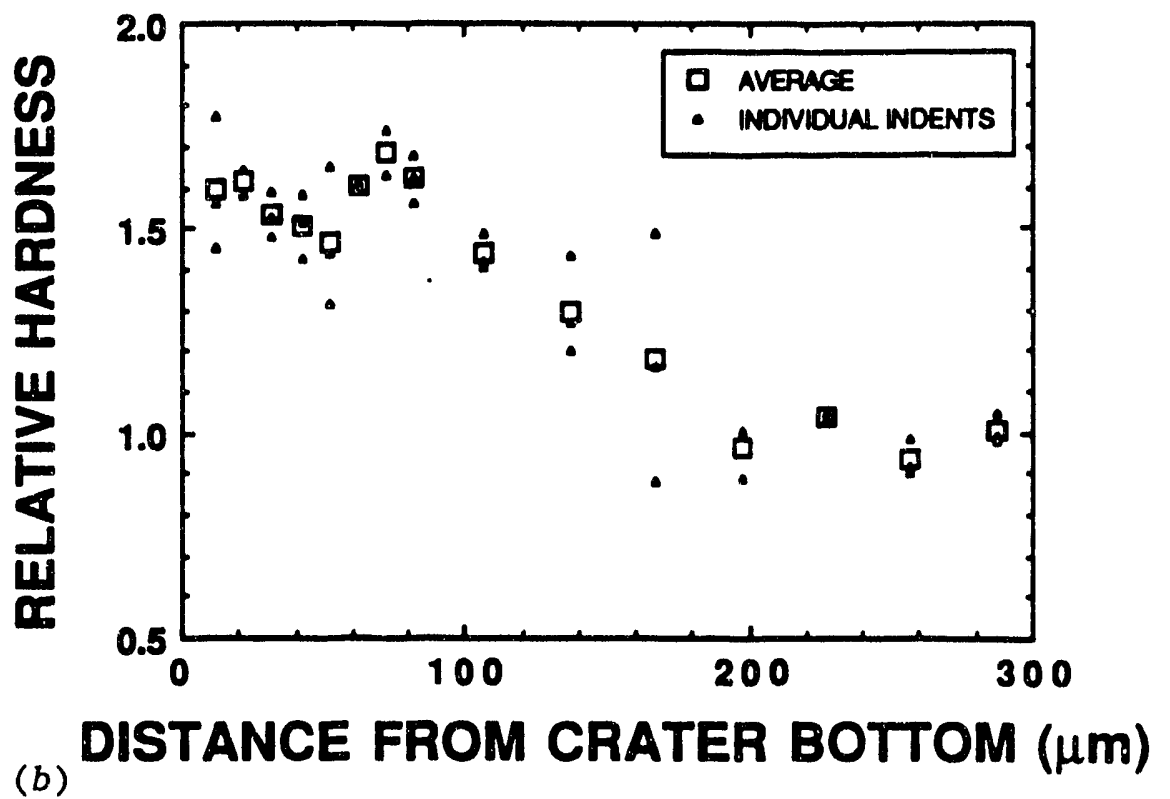

Fig. 2.3-8. MPM hardness profiles beneath craters formed due to impacts of single $343 \mu \mathrm{m}$ diameter WC balls at $90^{\circ}$ incidence on (a) iron aluminide alloy and (b) iron aluminide alloy reduced $5 \%$ by cold rolling. 


\subsubsection{References}

1. N. S. Stolloff and R. G. Davies, "The plastic deformation of Ordered FeCo and $\mathrm{Fe}_{3} \mathrm{Al}$ Alloys," Acta Metall. 12, 473-85, (1964).

2. P. Morgand, P. Mouturat, and G. Sainfort, "Structure et proprietes mecaniques des alliages fer-aluminium," Acta Metall. 16, 867-75 (1968).

3. R. G. Bordeau, Development of Iron Aluminides, Air Force Wright Aeronautical Laboratories, AFWAL-TR-87-4009, March 1986.

4. V. K. Sikka, C. G. McKamey, C. R. Howell, and R. H. Baldwin, Fabrication and Mechanical Properties of $\mathrm{Fe}_{3}$ Al-based Iron Aluminides, ORNL/TM-11465, Oak Ridge National Laboratory, Oak Ridge, TN (March 1990).

5. T. H. Kosel, R. O. Scattergood, and A. P. L. Turner, "An Electron Microscopic Study of Erosive Wear," pp. 192-204 in Proceedings of the International Conference on Wear of Materials, 1979, ed. K. C. Ludema, W. A. Glaeser, and S. K. Rhee, ASME, New York, 1979.

6. I. Finnie, J. Wolak, and Y. Kabil, "Erosion of Metals by Solid Particles," J. Matls. 2, 682-700 (1967).

7. T. Foley and A. Levy, "The Effect of Heat Treatment on the Erosion Behavior of Steel," Wear 91, 45-64 (1983).

8. M. E. Gulden, Influence of Brittle to Ductile Transition on Solid Particle Erosion Behavior. In J. E. Field (ed.), Proceeding of the 5th International Conference on Erosion by Liquid and Solid Impact, 1979, Cavendish Laboratory, University of Cambridge, 1979, paper no. 31 .

9. A. K. Cousens and I. M. Hutchings, Influence of Erodent Particle Shape in the Erosion of Mild Steel. In J. E. Field (ed.), Proceedings of the 6th International Conference on Erosion by Liquid and Solid Impact, 1983, Cavendish Laboratory, University of Cambridge, 1983, paper no. 41.

10. L. G. Peterson, G. A. Sargent, and H. Conrad, "Effect of Microstructure on the Erosion of Steels by Solid Particles," pp. 661-670 in K. C. Ludema (ed.), Proceedings of the International Conference on Wear of Materials, 1985, ASME, New York, 1985.

11. M. Rao, J. R. Keiser, and D. W. Wilson, "A Study of the Early Stages of Erosion of 1100 Aluminum Using a Mechanical Properties Microprobe," Scripta Metall. 23, 1475-80 (1989).

12. M. Rao, .. R. Keiser, and D. W. Wilson, "Subsurface Hardening and Flow of Aluminum During the Incubation Period of Solid Particle Erosion," in Proceedings of the 4th Berkeley Conference on Corrosion-Erosion-Wear at Elevated Temperatures, Berkeley, CA, January 31 - February 2, 1990, NACE, Houston, TX, to be published. 
13. J. R. Keiser, M. Rao, and D. W. Wilson, Material Behavior During Solid Particle Erosion of Annealed 1100 Aluminum. In R. R. Judkins and D. N. Braski (comp.), Proceedings of the 4th Annual Conference on Fossil Energy Materials, Oak Ridge, TN, May 15-17, 1990, Conf. 900546, ORNL/FMP-90/1, Oak Ridge National Laboratory, 1990, pp. 391-404.

14. I. M. Hutchings and A. V. Levy, "Thermal Effects in the Erosion of Ductile Metals," Wear 131, 105-21 (1989).

15. A. J. Ninham, The Effect of Mechanical Properties on Erosion, Wear 12, 307-24 (1988).

16. I. Finnie and Y. H. Kabil, "On the Formation of Surface Ripples During Erosion," Wear 8, 60-69 (1965).

17. J. R. Keiser, R. S. Heidersbarih, D. L. Dobbs, Jr., and W. C. Oliver, "Characteristics of Individual Impact Craters on Selected Aluminum Alloys," Wear 124, 105-18 (1988).

18. M. Rao, J. Keiser, B. Wang, and A. Levy, "Mechanical Behavior of Erosion-Corrosion Scales as Characterized by Single Particle Impacts," submitted for publication to Wear.

19. W. Zhu and Z. Y. Mao, Study of Erosion by Relatively Soft Particles, pp. 787-96, in Proceedings of the International Conference on Wear of Materials, 1987, ed. K. C. Ludema, ASME, New York, 1987.

20. S. S. Aptekar and T. H. Kosel, "Erosion of White Cast Irons and Stallite," pp. 677-86 in Proceedings of the Interantional Conference on Wear of Materials, 1985 ed. K. C. Ludema, ASME, New York, 1985.

\subsection{TECHNOLOGY ASSESSMENT AND TECHNOLOGY TRANSFER}

\subsubsection{Coal Conversion and Utilization Plant Support Services - J. R. Keiser and M. Howell}

In November 1990, a scheduled shutdown at the Advanced Coal Liquefaction Research and Development Facility at Wilsonville, Alabama, provided an opportunity for ten racks of corrosion samples to be removed and examined. These samples were exposed from July 1987 until November 1990, while the plant was operating with the two reactors in a close-coupled integrated two stage liquefaction mode. Coal processed was obtained from several seams including Ohio No. 6, Illinois No. 6, and Pittsburgh No. 8, as well as Texas lignite anci several subbituminous coals. Two types of corrosion samples are used at Wilsonville; corrosion coupons and u-bend samples. The coupons are nominally $5.1 \mathrm{~cm}(2 \mathrm{in}$.) squares of sheet material which provide information about general corrosion rates. The u-bend samples are 
intended to provide information on stress corrosion cracking, but general corrosion information can also be derived by weighing the samples before and after exposure in the same manner used for the corrosion coupons. The samples removed during the November 1990 shutdown included seven racks of corrosion coupons and three racks of u-bend samples.

Two racks of corrosion coupons were removed from the T102 Vacuum Distillation Tower. The samples had been exposed a total of $13,548 \mathrm{~h}$ with one rack at the upper manway where the temperature was $232-288^{\circ} \mathrm{C}\left(450-550^{\circ} \mathrm{F}\right)$ and the other rack at the lower manway where the temperature was $316-343^{\circ} \mathrm{C}\left(600-650^{\circ} \mathrm{F}\right)$. The calculated corrosion rates for the samples exposed at the upper manway are shown in Table 2.4-1, and these indicate that even carbon and low alloy steels corroded at a rate less than $0.127 \mathrm{~mm} / \mathrm{y}(5 \mathrm{mil} / \mathrm{y})$. The coupons exposed at the lower manway were subjected to somewhat higher temperatures, but the calculated corrosion rates listed in Table 2.4-2 are only slightly higher. For both racks of samples exposed in T102, negligible corrosion rates were measured for the austenitic and duplex stainless steels as well as the nickel-base alloy Haynes 263.

The T105B Atmospheric Distillation Tower actually contains eleven racks of ORNL supplied samples. Five racks of corrosion coupons are mounted on selected trays so that local variations of corrosion can be closely monitored. These racks are located in the portion of the column where the amine hydrochloride corrosion problem was previously encountered. These sample racks can only be removed and examined when the trays are removed from the tower, so examination is infrequent and was not performed this time. The other six racks consist of three $u$-bend and three coupon racks with one of each type mounted on the top, middle, and bottom manway covers.

The sample racks mounted on the top manway cover of T105B were exposed for 16,301 hours at $149-204^{\circ} \mathrm{C}\left(300-400^{\circ} \mathrm{F}\right)$. Calculated corrosion rates for the coupons are shown in Table 2.4-3, and these indicate that the corrosion rate for chrome-moly steels decreases with increasing alloy content but is probably excessive for long-time use. The more highly alloyed iron-base alloys all had corrosion rates below $0.076 \mathrm{~mm} / \mathrm{y}(3 \mathrm{mil} / \mathrm{y})$. Corrosion rates calculated for the u-bend samples are shown in Table 2.4-4, and they match up very well with the rates of the coupons in the same location. Corrosion rates for the austenitic and nickel base alloys are well within acceptable limits. 
As shown in Table 2.4-5, the coupons mounted at the middle manway had corrosion rates very similar to those on the top manway rack even though the temperature, $204-260^{\circ} \mathrm{C}$ $\left(40-500^{\circ} \mathrm{F}\right)$, was somewhat higher. Carbon steel corroded at a rate of about $0.51 \mathrm{~mm} / \mathrm{y}$ (20 mil/y) while the austenitic stainless steels were all below $0.051 \mathrm{~mm} / \mathrm{y}(2 \mathrm{mil} / \mathrm{y})$. The u-bend samples exposed at the middle manway had corrosion rates (Table 2.4-6) slightly lower than both the coupons at the same location and the u-bends exposed at the cooler upper manway.

The samples located on the bottom manway cover were at an even higher temperature [260-316 $\left.\mathrm{C}\left(500-600^{\circ} \mathrm{F}\right)\right]$, but calculated coupon corrosion rates were lower as shown in Table 2.4-7. Carbon steel corroded at a rate about one third that at the higher, cooler manways, and the austenitic stainless steels all corroded at a rate no greater than $0.007 \mathrm{~mm} / \mathrm{y}$ ( $0.3 \mathrm{mil} / \mathrm{y})$. Corrosion rates calculated for the u-bend samples are shown in Table $2.4-8$, and, they compare very well with those for coupons exposed in the same location. Again, corrosion rates for the austenitic and nickel base alloys are well within acceptable limits.

Vessel V1258, the High Pressure Separator, is not used in all modes of operation, consequently, the exposure time for samples in this vessel was only $7325 \mathrm{~h}$ during the $40 \mathrm{~m}$ exposure period. The vessel operates at relatively high temperature $399-454^{\circ} \mathrm{C}\left(750-850^{\circ} \mathrm{F}\right)$, and, as a result, the corrosion rates of carbon and chrome-moly steels were quite high. As indicated in Table 2.4-9, modified $9 \mathrm{Cr}-1$ Mo steel had a corrosion rate of $0.509 \mathrm{~mm} / \mathrm{y}$ (20.0 mil/y), and the alloys with lower chromium content corroded so extensively that the identifying marks were removed. Alloys with chromium content of $12 \%$ or greater had corrosion rates less than $0.051 \mathrm{~mm} / \mathrm{y}(2.0 \mathrm{mil} / \mathrm{y})$.

Corrosion samples have also been exposed in the reactor vessels; for this period samples were only exposed in R1235. Because of the limited space available and the small diameter of the nozzle through which the samples are inserted, smaller coupons are required, and, consequently, the exposed surface is considerably less. Calculated corrosion rates for coupons exposed 16,301 hours at a temperature of $404-457^{\circ} \mathrm{C}\left(760-855^{\circ} \mathrm{F}\right)$ in $\mathrm{R} 1235$ are given in Table 2.4-10. These results show that corrosion rates are no greater than $0.051 \mathrm{~mm} / \mathrm{y}$ $(2.0 \mathrm{mil} / \mathrm{y})$ for iron and nickel base alloys that contain at least $17 \%$ chromium.

The corrosion samples removed during the November 1990 shutdown indicated relatively low corrosion rates for austenitic stainless steels in all areas studies. In many areas corrosion rates of lower alloy materials were acceptable. 
Table 2.4-1. Calculated corrosion rates for corrosion coupons exposed for 13,548 $\mathrm{h}$ at the upper manway cover of

T102 Vacuum Distillation Tower

\begin{tabular}{|c|c|c|}
\hline \multirow[b]{2}{*}{ Material } & \multicolumn{2}{|c|}{ Calculated corrosion rate } \\
\hline & $\mathrm{mm} / \mathrm{y}$ & $\operatorname{mil} / \mathrm{y}$ \\
\hline $2.25 \mathrm{Cr}-1 \mathrm{Mo}$ & 0.107 & 4.2 \\
\hline Carbon steel & 0.105 & 4.1 \\
\hline $5 \mathrm{Cr}-1 \mathrm{Mo}$ & 0.054 & 2.1 \\
\hline $7 \mathrm{Cr}-1$ mo & 0.046 & 1.8 \\
\hline Modified $9 \mathrm{Cr}-1$ Mo & 0.009 & 0.4 \\
\hline Type 409 stainless steel & 0.006 & 0.2 \\
\hline Type 304 stainless steel & $<0.003$ & $<0.1$ \\
\hline Type 316 stainless steel & $<0.003$ & $<0.1$ \\
\hline Type 321 stainless steel & $<0.003$ & $<0.1$ \\
\hline Type 347 stainless steel & $<0.003$ & $<0.1$ \\
\hline SAF 2205 (duplex steel) & $<0.003$ & $<0.1$ \\
\hline Ferralium (duplex stee1) & $<0.003$ & $<0.1$ \\
\hline $18 \mathrm{Cr}-2 \mathrm{Mo}$ & $<0.003$ & $<0.1$ \\
\hline Haynes 263 & $<0.003$ & $<0.1$ \\
\hline
\end{tabular}

"Corrosion rates calculated assuming uniform removal of material from exposed surfaces.

Table 2.4-2. Calculated corrosion rates for corrosion coupons exposed for $13,548 \mathrm{~h}$ at the lower manway cover of T102 Vacuum Distillation Tower

\begin{tabular}{|c|c|c|}
\hline \multirow[b]{2}{*}{ Material } & \multicolumn{2}{|c|}{ Calculated corrosion rate } \\
\hline & $\mathrm{mm} / \mathrm{y}$ & $\mathrm{mil} / \mathrm{y}$ \\
\hline $2.25 \mathrm{Cr}-1 \mathrm{Mo}$ & 0.133 & 5.2 \\
\hline Type 409 stainless steel & 0.105 & 4.1 \\
\hline $5 \mathrm{Cr}-1 \mathrm{Mo}$ & 0.096 & 3.8 \\
\hline $7 \mathrm{Cr}-1$ mo & 0.081 & 3.2 \\
\hline Carbon steel & 0.072 & 2.9 \\
\hline Modified $9 \mathrm{Cr}-1$ mo & 0.066 & 2.6 \\
\hline $18 \mathrm{Cr}-2 \mathrm{Mo}$ & 0.041 & 1.6 \\
\hline Haynes 263 & $<0.003$ & $<0.1$ \\
\hline Ferralium & $<0.003$ & $<0.1$ \\
\hline SAF 2205 & $<0.003$ & $<0.1$ \\
\hline Type 304 stainless steel & $<0.003$ & $<0.1$ \\
\hline Type 321 stainless steel & $<0.003$ & $<0.1$ \\
\hline Type 347 stainless steel & $<0.003$ & $<0.1$ \\
\hline Type 316 stainless steel & $<0.003$ & $<0.1$ \\
\hline
\end{tabular}


Table 2.4-3. Calculated corrosion rates for corrosion coupons exposed for $16,301 \mathrm{~h}$ at the top manway of T105B

Atmospheric Distillation Tower

\begin{tabular}{|c|c|c|}
\hline \multirow[b]{2}{*}{ Material } & \multicolumn{2}{|c|}{ Calculated corrosion rate } \\
\hline & $\mathrm{mm} / \mathrm{y}$ & $\mathrm{mil} / \mathrm{y}$ \\
\hline Carbon steel & 0.467 & 18.3 \\
\hline $5 \mathrm{Cr}-1$ Mo (heat 5) & 0.251 & 9.9 \\
\hline $5 \mathrm{Cr}-1$ Mo (heat 6) & 0.247 & 9.7 \\
\hline $7 \mathrm{Cr}-1$ Mo (heat 8) & 0.216 & 8.5 \\
\hline $7 \mathrm{Cr}-1$ Mo (heat 7) & 0.208 & 8.2 \\
\hline Modified $9 \mathrm{Cr}-1$ Mo & 0.188 & 7.4 \\
\hline $9 \mathrm{Cr}-1 \mathrm{Mo}$ & 0.138 & 5.4 \\
\hline Type 304 stainless steel & 0.067 & 2.6 \\
\hline $18 \mathrm{Cr}-2 \mathrm{Mo}$ & 0.064 & 2.5 \\
\hline Type 316 stainless steel & 0.046 & 1.8 \\
\hline Type 317LM stainless steel & 0.028 & 1.1 \\
\hline Incoloy 800 & 0.028 & 1.1 \\
\hline Incoloy 825 & 0.026 & 1.0 \\
\hline $29 \mathrm{Cr}-4 \mathrm{Mo}$ & 0.023 & 0.9 \\
\hline Haynes 263 & 0.011 & 0.4 \\
\hline Titanium & $<0.003$ & $<0.1$ \\
\hline
\end{tabular}

"Corrosion rates calculated assuming uniform removal of material from exposed surfaces.

Table 2.4-4. Calculated corrosion rates for u-bend samples exposed for $16,301 \mathrm{~h}$ at the top manway of T105B

Atmospheric Distillation Tower

\begin{tabular}{lcc}
\hline \multicolumn{1}{c}{ Material } & \multicolumn{2}{c}{ Calculated corrosion rate* } \\
& $\mathrm{mm} / \mathrm{y}$ & $\mathrm{mil} / \mathrm{y}$ \\
\hline Welded type 410 stainless steel & 0.152 & 6.0 \\
Welded type 304L stainless steel & 0.066 & 2.6 \\
Welded type 321 stainless steel & 0.062 & 2.4 \\
Ferralium & 0.051 & 2.0 \\
Welded type 316 stainless steel & 0.046 & 1.8 \\
Welded type 310 stainless steel & 0.043 & 1.7 \\
Welded type 317L stainless steel & 0.041 & 1.6 \\
Welded Inconel 625 & 0.019 & 0.7 \\
Welded Hastelloy C-276 & $<0.003$ & $<0.1$ \\
\hline
\end{tabular}

*Corrosion rates calculated assuming uniform removal of material from exposed surfaces. 
Table 2.4-5. Calculated corrosion rates for corrosion coupons exposed for $16,301 \mathrm{~h}$ at the middle manway of T105B

Atmospheric Distillation Tower

\begin{tabular}{lrr} 
& \multicolumn{3}{c}{ Calculated corrosion rate* } \\
\cline { 2 - 3 } Material & $\mathrm{mm} / \mathrm{y}$ & $\mathrm{mil/y}$ \\
\hline Carbon steel & 0.535 & 21.0 \\
Mone1 400 & 0.064 & 2.5 \\
Type 316 stainless stee1 & 0.044 & 1.7 \\
Type 321 stainless steel & 0.042 & 1.6 \\
Carpenter 20Cb3 & 0.039 & 1.6 \\
Alloy 904L & 0.037 & 1.4 \\
Type 317LM stainless stee1 & 0.025 & 1.0 \\
Crutemp 25 & 0.023 & 0.9 \\
Incoloy 825 & 0.019 & 0.7 \\
Haynes 20 mod & 0.017 & 0.7 \\
Crucible 6M & 0.013 & 0.5 \\
Incone1 600 & 0.006 & 0.2 \\
Haynes 263 & 0.004 & 0.2 \\
Titanium & $<0.003$ & $<0.1$ \\
Hastelloy C-276 & $<0.003$ & $<0.1$ \\
\hline
\end{tabular}

*Corrosion rates calculated assuming uniform removal of material from exposed surfaces.

Table 2.4-6. Calculated corrosion rates for u-bend samples exposed for $16,301 \mathrm{~h}$ at the middle manway of $\mathrm{T} 105 \mathrm{~B}$

Atmospheric Distillation Tower

\begin{tabular}{|c|c|c|}
\hline \multirow[b]{2}{*}{ Material } & \multicolumn{2}{|c|}{ Calculated corrosion rate ${ }^{*}$} \\
\hline & $\mathrm{mm} / \mathrm{y}$ & $\mathrm{mil} / \mathrm{y}$ \\
\hline Welded type 410 stainless steel & 0.147 & 5.8 \\
\hline Welded type 310 stainless steel & 0.068 & 2.7 \\
\hline Welded type $304 \mathrm{~L}$ stainless steel & 0.067 & 2.6 \\
\hline Welded type 321 stainless steel & 0.057 & 2.3 \\
\hline Welded type 316 stainless steel & 0.054 & 2.1 \\
\hline Welded type 347 stainless steel & 0.049 & 1.9 \\
\hline Welded type $317 \mathrm{~L}$ stainless steel & 0.030 & 1.2 \\
\hline Welded Inconel 625 & 0.015 & 0.6 \\
\hline Welded Hastelloy C-276 & $<0.003$ & $<0.1$ \\
\hline
\end{tabular}

${ }^{\star}$ Corrosion rates calculated assuming uniform removal of material from exposed surfaces. 
Table 2.4-7. Calculated corrosion rates for corrosion coupons exposed for $16,301 \mathrm{~h}$ at the bottom manway of $\mathrm{T} 105 \mathrm{~B}$

Atmospheric Distillation Tower

\begin{tabular}{lcc}
\hline \multicolumn{1}{c}{ Material } & \multicolumn{1}{c}{ Calculated crosion rate* } \\
\cline { 2 - 3 } & $\mathrm{mil} / \mathrm{y}$ \\
\hline Mone1 400 & 0.241 & 9.5 \\
Carbon Steel & 0.161 & 6.3 \\
9 Cr-1 Mo & 0.046 & 1.8 \\
Type 317L stainless steel & 0.008 & 0.3 \\
Type 316 stainless steel & 0.005 & 0.2 \\
Incoloy 825 & 0.003 & 0.1 \\
Carpenter 20Cb3 & 0.003 & 0.1 \\
Type 304 stainless steel & $<0.003$ & $<0.1$ \\
Haynes 20 Mod & $<0.003$ & $<0.1$ \\
Crucible 6M & $<0.003$ & $<0.1$ \\
Type 321 stainless steel & $<0.003$ & $<0.1$ \\
Hastelloy C-276 & $<0.003$ & $<0.1$ \\
Haynes 263 & $<0.003$ & $<0.1$ \\
Alloy 904L & $<0.003$ & $<0.1$ \\
\hline
\end{tabular}

*Corrosion rates calculated assuming uniform removal of material from exposed surfaces.

Table 2.4-8. Calculated corrosion rates for u-bend samples exposed for $16,301 \mathrm{~h}$ at the bottom manway of T105B

Atmospheric Distillation Tower

\begin{tabular}{lcc}
\hline \multicolumn{1}{c}{ Material } & \multicolumn{2}{c}{ Calculated corrosion rate* } \\
\cline { 2 - 2 } & $\mathrm{m} / \mathrm{y}$ & $\mathrm{m} / \mathrm{y}$ \\
\hline Welded type 410 stainless steel & 0.038 & 1.5 \\
Welded type 310 stainless steel & 0.004 & 0.2 \\
Welded type 347 stainless steel & 0.004 & 0.1 \\
Welded type 304L stainless steel & 0.003 & 0.1 \\
Welded type 321 stainless steel & $<0.003$ & $<0.1$ \\
Welded type 317L stainless steel & $<0.003$ & $<0.1$ \\
Welded type 316 stainless steel & $<0.003$ & $<0.1$ \\
Welded Hastelloy C-276 & $<0.003$ & $<0.1$ \\
Welded Incone1 625 & $<0.003$ & $<0.1$ \\
Ferralium & $<0.003$ & $<0.1$ \\
\hline
\end{tabular}

"Corrosion rates calculated assuming uniform removal of material from exposed surfaces. 
Table 2.4-9. Calculated corrosion rates for corrosion coupons exposed for 7,325 $\mathrm{h}$ in the V1258 High Pressure Separator

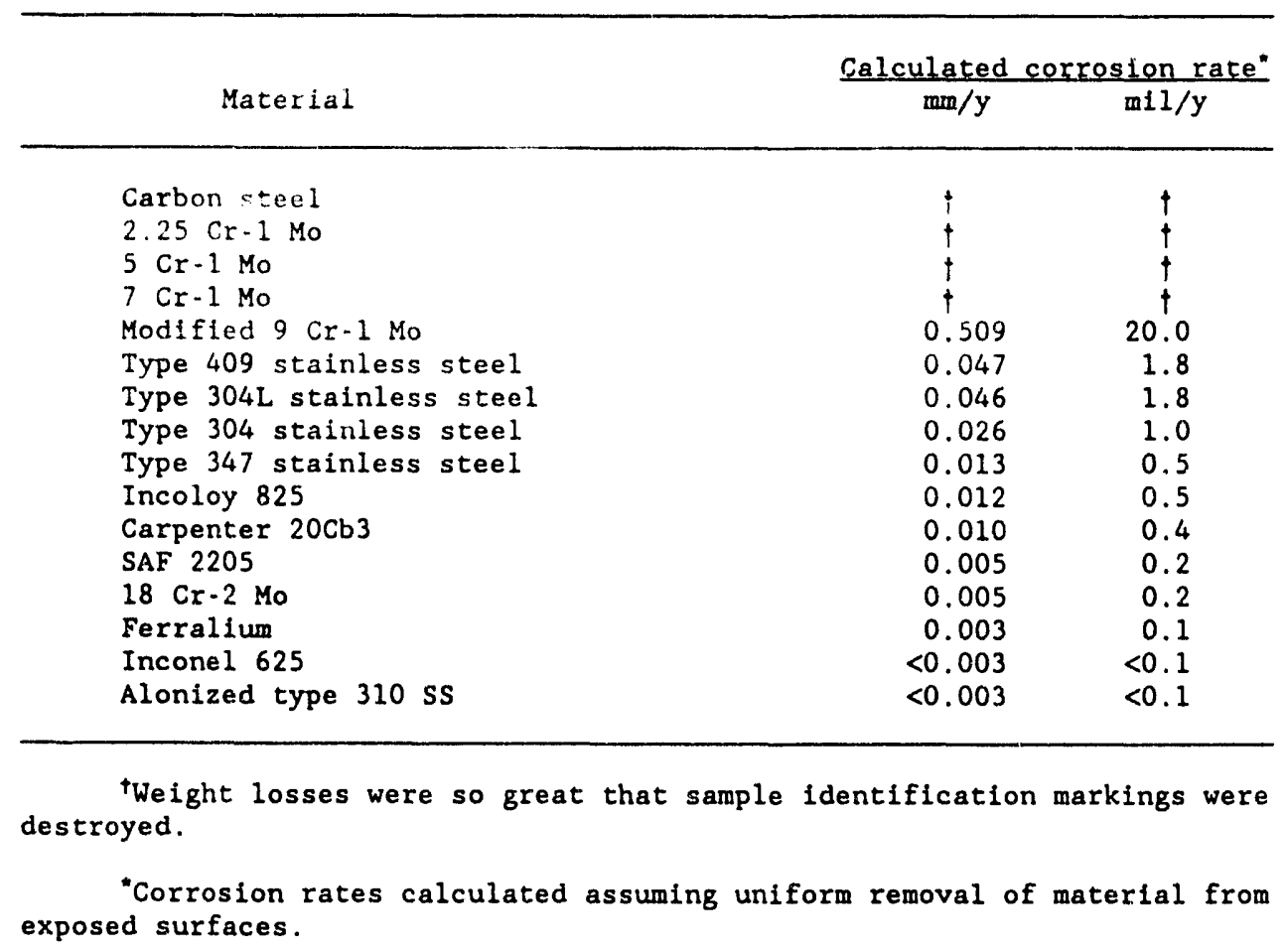

Table 2.4-10. Calculated corrosion rates for coupons exposed for $16,301 \mathrm{~h}$ through nozzle near top of vessel in First Stage Reactor R1235

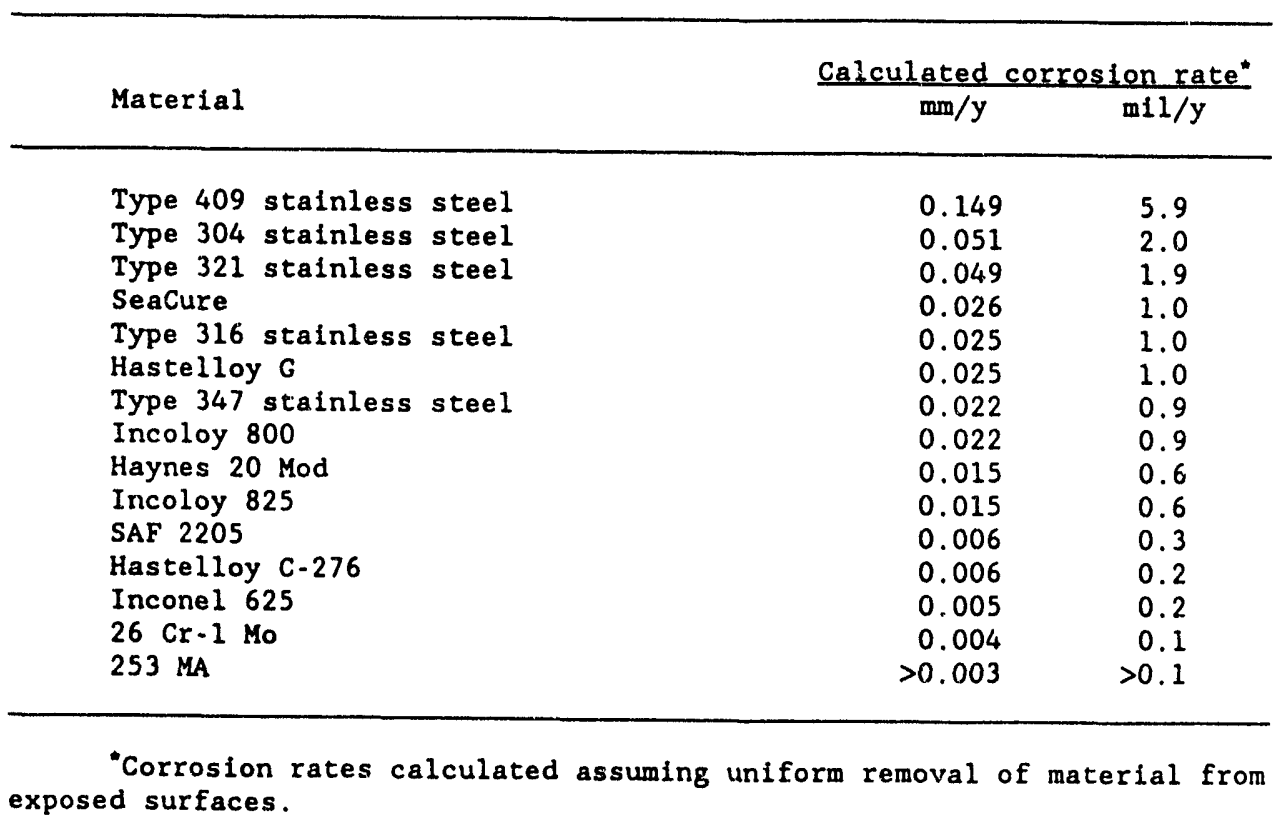




\title{
3. ENVIRONMENTAL ANALYSIS AND INFORMATION SYSTEMS
}

\author{
C. R. Boston
}

Activities in environmental analysis and information systems included assistance to the DOE Office of Clean Coal Technology by preparing four issue papers discussing environmental topics related to the Clean Coal Program, especially the effects of commercial deployment of clean coal technologies on those topic areas. Topics selected for the papers were acid deposition, the Clean Air Act Amendments of 1990, global climate change, and solid waste.

ORNL is also providing assistance to the Morgantown and Pittsburgh Energy Technology Centers (METC and PETC) in reviewing and preparing documents required by the National Environmental Policy Act (NEPA) for several projects selected for the Clean Coal Program. A key activity was the preparation for PETC of a preliminary draft Environmental Impact Statement (EIS) for the Healy Clean Coal Project in Healy, Alaska. This work is notable because it is the first site-specific EIS prepared for the Clean Coal Program.

\subsection{ENVIRONMENTAL SUPPORT TO THE CLEAN COAL PROGRAM -R. L. Miller}

Activities included assistance to the DOE Office of Clean Coal Technology by preparing four issue papers discussing environmental topics related to the Clean Coal Program, particularly the effects of commercial deployment of clean coal technologies on those topic areas. Topics selected for the papers were acid deposition, the Clean Air Act Amendments of 1990, global climate change, and solid waste.

The first paper discussing acid deposition concluded that reductions in sulfur dioxide $\left(\mathrm{SO}_{2}\right)$ emissions associated with the widespread commercialization of clean coal technologies should reduce sulfur deposition (the predominant form of acid deposition), especially in the northeastern U.S. and southeastern Canada. However, the second paper found that the relatively tight deadlines imposed by the Clean Air Act Amendments of 1990 preclude significant immediate contributions by the Clean Coal Program. Many utilities are expected to divert funds from clean coal research and demonstration; most utilities will opt for fuelswitching or buying current-generation, proven but expensive emissions controls. The global 
climate change paper concluded that full implementation of clean coal technologies in the United States by the year 2010 would reduce the rate of global fossil-fuel carbon dioxide input to the atmosphere by about $2 \%$. Although this percentage at first appears small, it becomes more impressive when compared to reductions achievable by other technologies or policy implementations that likewise are no more than a few percent. The solid waste paper found that clean coal technologies have the potential to generate considerably more to considerably less waste than conventional wet lime/limestone flue gas desulfurization technologies. Most of the technologies that are expected to generate less waste than conventional technologies do so by producing a salable byproduct.

Other work during this six-month period focused on the preparation for DOE's Pittsburgh Energy Technology Center (PETC) of a preliminary draft Environmental Impact Statement (EIS) for the Healy Clean Coal Project (HCCP). The project, proposed by the Alaska Industrial Development and Export Authority and selected by DOE in the third solicitation of the Clean Coal Program, would be located in Healy, Alaska, about 4 miles north of the nearest border of Denali National Park and Preserve (DNPP). The proposed project is a new 50 megawatt coal-fired power generating facility that would be collocated with an existing 25 megawatt conventional pulverized-coal unit owned and operated by Golden Valley Electric Association. The new facility would feature integration of advanced combustion and flue gas cleanup technologies to reduce emissions of $\mathrm{SO}_{2}$ and $\mathrm{NO}_{x}$. The EIS is notable because it is the first site-specific EIS prepared for the Clean Coal Program.

Impacts to air quality, surface water, groundwater, and ecological and socioeconomic resources from construction and operation of the HCCP were evaluated and preliminary results indicate that, for most resource areas, the impacts are not expected to be significant. Tentative findings for areas of potential concern are summarized below. Of primary concern, as predicted by analyses based on computer models, is the degradation of air quality and visibility expected in portions of DNPP because of HCCP operation. Also, during the winter, the length of ice-free water in the Nenana River downstream of the HCCP is expected to increase because of the HCCP's thermal discharge of once-through cooling water. Consequently, ice bridge formation on the river at the village of Ferry, located about 10 miles downstream, may be affected (the ice bridge is used by residents to transport supplies across the river during winter). Finally, moderate socioeconomic impacts are expected during construction and operation of the $\mathrm{HCCP}$, particularly in the areas of housing, education, traffic, police and fire protection, and medical services. 
Additional activities included reviews of Environmental Information Volumes and Environmental Monitoring Plans prepared by the project participants for Clean Coal projects. The final Environmental Information Volumes are used by ORNL as a resource in preparing environmental documentation such as EIS's or Environmental Assessments (EA's) for the projects. 


\title{
4. COAL CONVERSION DEVELOPMENT
}

\author{
C. D. Scott
}

Coal conversion research has continued on the biological solubilization of coal and the characterization of mild gasification product.

4.1 BIOLOGICAL COAL CONVERSION - C. D. Scott, B. D. Faison, J. Woodward, C. A. Woodward, and R. R. Brunson

This program has examined the feasibility of using biological catalysts for the conversion of coal to useful liquid fuels. Biological reagents potentially useful in this application include intact microorganisms in pure or mixed culture and isolated enzymes. These biocatalysts are employed in aqueous or organic media which would support the formation of solubilization products. There is particular interest in reduced (nonoxidized) products.

Two approaches to biological coal conversion are under consideration: (1) direct anaerobic microbial solubilization, and (2) direct anaerobic enzymatic solubilization. The efforts during this period have reflected our continued emphasis on these tasks, including the testing of microbial cultures capable of anaerobic interactions with coal and the further investigation of anaerobic enzyme solubilization of coal in organic solvents. A new research program has also been initiated that includes the fundamental investigation of biological catalysis in organic media. The results of this research support the ongoing applied research on coal solubilization summarized here and in previous reports.

\subsubsection{Background}

A comprehensive rationale has been previously established for the approaches used in the research for the tasks included in this program. A summary is included here for completeness.

\subsubsection{Anacrobic Microbial Coal Conversion}

This approach to biological coal conversion requires the solubilization of coal through microbial activity followed by the further metabolism of the solubilized material to minimally oxidized liquid products within the same culture. The hypothesized products of an anaerobic 
microbial coal conversion process would include low-molecular-weight aromatic and aliphatic acids, alcohols, and ketones.

A rational approach to the development of an anaerobic microbial conversion will be utilized in this work. A number of types of organisms potentially useful in this application are being considered, including those isolated from coal. The principal substrate for anaerobic microbial coal conversion will be native lignite or subbituminous coal. The microbial conversion is to be carried out in the absence of oxygen and under an inert or reducing atmosphere. The conversion reactions will initially be carried out in aqueous culture media, although partially or wholly nonaqueous systems will ultimately be considered.

\subsubsection{Anaerobic Enzymatic Solubilization of Coal}

The anaerobic enzymatic process will require the addition of hydrogen to the coal matrix and the probable removal of some oxygen and other heteroatoms. One can envision enzymes that can transfer the gaseous reagent $\left(\mathrm{H}_{2}\right)$,

$$
\text { Coal }+\mathrm{H}_{2}-- \text { (Hydrogenase) }-->\text { Reduced Coal Fragments;(1) }
$$

or utilize a hydrogen donor such as $\mathrm{NADH}$ or even other enzymes such as reduced cytochrome $\mathrm{c}$ that can serve as electron carriers,

$$
\text { Coal + NADH -- (Dehydrogenase) -- > Reduced Coal Fragments. (2) }
$$

The most effective hydrogenase will likely be isolated from microorganisms such as Proteus vulgaris, Desulfovibrio desulfuricans, and Chromatium, or perhaps some of the more recently isolated deep-sea thermophiles.

It may be desirable to utilize a less polar, organic solvent instead of water as the coal solubilization agent since this would also allow easy removal of nonpolar products. Such an approach could prove to be particularly useful in the anaerobic solubilization of coal. Relatively folar organic solvents such as dioxane and pyridine will be considered even with some dissolved water present. Less polar organics such as benzene will also be considered. Most enzymes are sparingly soluble in organic liquids, but in some cases they may be chemically modified to enhance the solubility. This would have to be done in a way that did not significantly affect the enzyme activity. 


\subsubsection{Results}

\subsubsection{Anacrobic Microbial Coal Conversion}

Research on microbial systems has concentrated on the cultivation and study of the mixed cultures obtained as microbial contaminants isolated from Argonne premium coal samples. In previous work, these cultures had been shown capable of producing methane, various alcohols (ethanol, isopropanol, and butanol), and acetate when cultivated under a nitrogen atmosphere at ambient temperature. The cultures were capable of utilizing acetate or benzoate, an aliphatic and an aromatic coal substructure model compound respectively, as carbon source. Cultures from subbituminous and bituminous coal samples produced more biomass during growth on benzoate than did cultures obtained from lignite, suggesting greater activity toward aromatic substrates. Activities during this reporting period have therefore focused exclusively on cultures obtained from subbituminous and bituminous coals.

\subsection{Culture Enrichment}

A major goal of the work reported here was the enhancement of the previously demonstrated culture activity toward aromatic substrates. In keeping with classical microbiological technique, it may be presumed that sequential transfers into medium containing the desired substrate would increase the proportion of organisms utilizing that compound. To this end, culture enrichment was carried out. Unsterilized Argonne premium subbituminous or bituminous coal samples (two different samples of each) were transferred anaerobically to medium containing $1 \%$ sodium benzoate. Previous cultures had been isolated from medium containing glucose, perhaps selecting against hydrocarbon-utilizers. Cultures were incubated at ambient temperature under a nitrogen atmosphere and strict anaerobiosis. Previous cultures had also been incubated microaerophilically, perhaps killing more sensitive anaerobic species. Several sequential transfers into media containing benzoate have been performed. Beginning on the third transfer, growth and product formation were monitored over the course of a $28 \mathrm{~d}$ incubation.

Sample results (derived from the third transfer) are presented in Table 4.1-1. Results of this work indicate that cell populations obtained from the two types of coal were distinctly different. Cultures from both subbituminous coal samples (S-1, S-2) grew more rapidly on benzoate than did the cultures from bituminous coal (B-1, B-2). Bituminous coal cultures also exhibited a lag before the initiation of active growth; no lag was observed in subbituminous 
coal cultures. Higher cell concentrations were achieved in subbituminous coal cultures than in bituminous coal cultures. However, there were also differences in the cell populations obtained from a given coal. Culture B-1 always grew more rapidly than culture B-2, although growth was sustained for a shorter period. The subbituminous coal cultures consistently produced large amounts of gas; the bituminous cultures did not. Most intriguingly, culture S-2 produced a brown color within the medium within $7 \mathrm{~d}$. The product(s) generated in cultures absorb maximally at 300 and 378 run. The amount of material absorbing at $378 \mathrm{~nm}$ increases over the course of the incubation, accounting for the increase in visible color. Gas chromatographic analysis of the sample failed to identify the colored metabolite. The original B-2 isolate also produced a brown color within $60 \mathrm{~d}$, during incubation in the presence of the coal from which it was isolated plus benzoate.

These findings suggest that in general, the ability to degrade a partially oxidized aromatic compound parallels the level of oxidation of the coal from which cultures were isolated. This hypothesis conflicts with the previously-reported finding that cells isolated from lignite grew extremely poorly on benzoate. However, the high volatile aliphatic content of lignite may effectively encourage the growth of organisms adapted to those substrates, at the expense of aromatic-utilizing organisms. The isolation procedure used in the previous work may also have impacted the culture composition.

Culture S-2 was shown to retain its ability to grown on acetate after four passages through medium containing benzoate as sole carbon source. This result shows that the ability to degrade aliphatic substrates is stable within cultures. The latter characteristic is critical to the complete degradation of coal substrates that contain both aromatic and aliphatic substructures.

\subsection{Product Analysis}

Pigment production in culture S-2 suggested the oxidative (but not necessarily oxygenative) degradation of benzoate to phenolic products, which may be colored. Oxidative substitution of the substrate is, in biochemical terms, necessary for ring cleavage. Ring cleavage is critical in turn to the effective conversion of coal, which is largely aromatic, to saturated aliphatic products such as fatty acids. Anaerobic oxidation is possible by transfer of oxygen atoms from water to other partially reduced substrates.

Cultures were acidified and extracted with ethyl acetate in an attempt to identify acidic metabolites. Thin-layer chromatographic (TLC) and gas chromatographic (GC) analyses of the 
extracts failed to detect catechol, an oxidized, oxygenated, chromophoric product known to be generated by many aerobic benzoate-degrading organisms, suggesting that the cultures were truly anaerobic. TLC and GC also did not detect phenol, a decarboxylation product that may be formed in the absence of ring cleavage activity. However, compounds with mobility similar to benzoate, plus a polar, acidic product (not benzoate) were detected by TLC. A gas chromatographic-mass spectroscopic (GC-MS) analysis revealed the presence of a five-carbon acidic, apparently aliphatic product plus compounds closely related to benzoate. The structures of the latter compounds could not be determined.

The results of this work provide very preliminary evidence that degradation of benzoate by culture S-2 proceeds by a pathway that results in ring cleavage. Failure to identify well-known intermediates such as adipate or pimelate prevents full pathway analysis.

However, the appearance of what seem to be benzoate transformation products suggests that a simple decarboxylation does not occur and is consistent with anaerobic ring substitution reactions. Also, the detection also of a five-carbon aliphatic acid strongly suggests ring cleavage.

Aqueous supernatants of culture S-2 were further analyzed by GC for the presence of alcohols or acids. There was evidence of tract amounts of ethanol and acetate in cultures; however, these results are very preliminary and must be confirmed.

Table 4.1-1. Growth of Argonne premium coal isolates in medium containing $1 \% \mathrm{Na}$ benzoate ( $3 \mathrm{rd}$ transfer)

Cell Counts $\times 10^{6}$

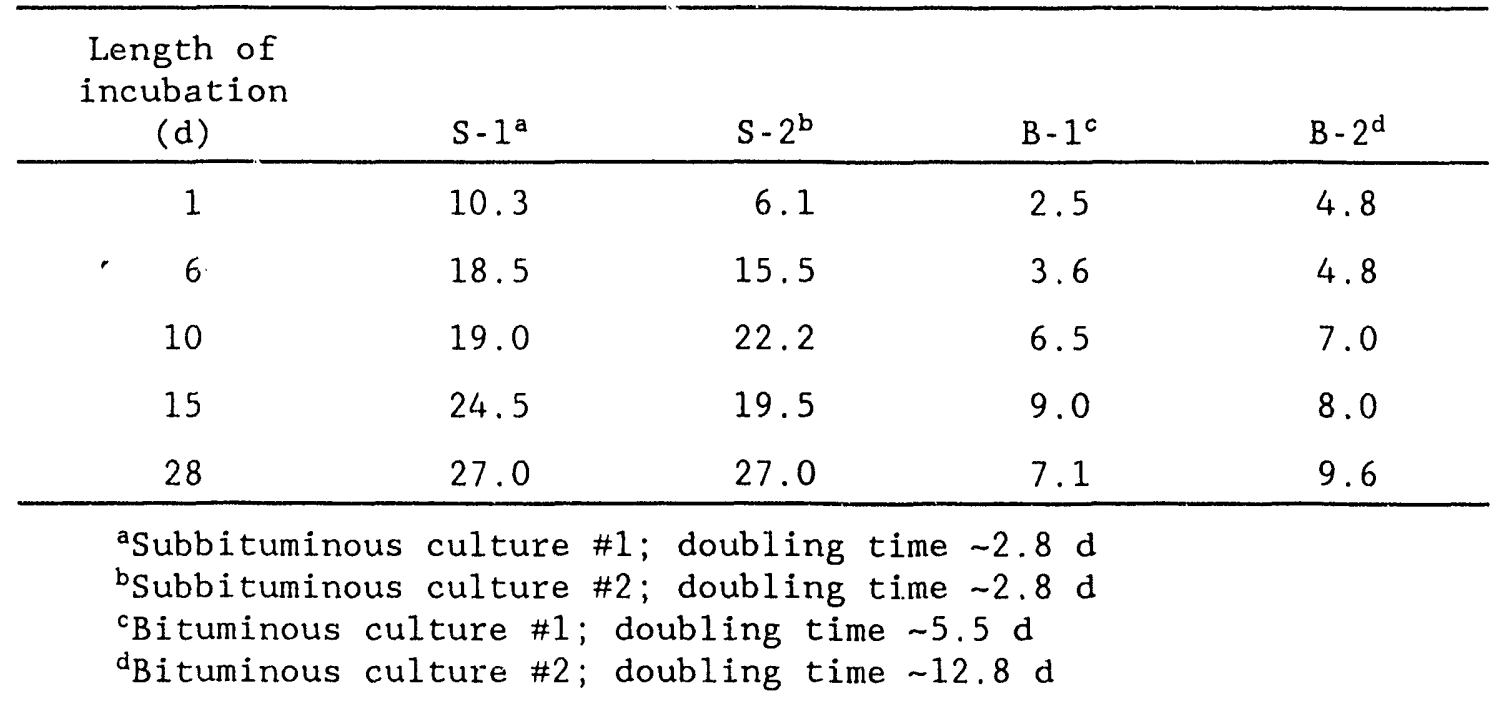




\subsubsection{Enzymatic Solubilization of Coal}

The dissolution of coal to low molecular weight aromatic fragments in an anaerobic environment could possibly be enhanced by the use of reducing enzymes. Coal contacted with enzymes in an organic medium should generate products that are relatively nonpolar as are the products of conventional thermal/chemical coal liquefaction processes. Since enzymes are generally incompatible with organic solvents, the enzymes must either be modified to decrease their effective polarity and increase their solubility in organic solutions or recovered in a hydrophobic state.

Two different approaches are currently being investigated: (1) chemical modification of the extracted enzyme to add hydrophobicity; and (2) the use of membrane-bound enzymes that are naturally in a hydrophobic environment for direct solubilization into the organic solvent. The solubilized enzymes must also have usable catalytic activity in the organic.

Experiments have focused on enhancement of enzyme solubilization in benzene and the reduction of model compounds dissolved in benzene. As in the past, two enzyme systems are being investigated: (1) cytochrome $\mathrm{C}$, available from a commercial source; and ( 2 ) hydrogenase extracted from Proteus vulgaris. The latter was recovered as either a free enzyme in aqueous solution or as membrane fragments that contained bound enzyme.

\subsection{Chemical Modification of Enzymes}

As described in previous progress reports, the main approach to chemical modification of enzymes to enhance the solubilization in organic solvents has been to interact the enzyme with methoxypolyethylene glycol activated with cyanuric chloride (PEG, available from Sigma Chemical Co.). The PEG, interacts with the free amino groups on the protein molecule resulting in a much larger molecule that is less polar. The PEG, is bound to the enzyme in an aqueous buffer at $\mathrm{pH} 10$ at $25^{\circ} \mathrm{C}$ for 1 hour, after which the $\mathrm{pH}$ is adjusted to 8 and the material is dialyzed to remove the unbound $\mathrm{PEG}_{1}$. After freeze drying, the dry, modified enzyme can be stored at $4^{\circ} \mathrm{C}$ and/or used by dissolution into the organic solvent. An optimum molar ratio of PEG, to the free amino groups within the enzyme has been established as 5:1 for cytochrome and 10:1 for hydrogenase.

Although PEG itself is somewhat soluble in benzene, it would perhaps be more appropriate to attach an aromatic chemical moiety that is relatively nonpolar and has a much greater solubility in benzene. To investigate this approach, the reagent dinitrofluorobenzene 
(DNFB) is being studied for enzyme modification. DNFB is know to interact with "free" amino groups on proteins and form a stable chemical complex. ${ }^{1}$ Hydrogenase isolated from Proteus vulgaris and cytochrome $\mathrm{C}$ obtained from Sigma Chemical Company were the two proteins tested. The technique for reacting DNFB with the enzymes was a modification of that of Sanger. ${ }^{1}$ The reaction solution was $15 \mathrm{~mL}$ of $67 \%$ ethanol in distilled water into which $0.5 \mathrm{~g}$ of $\mathrm{NaHCO}_{3}$ and $0.5 \mathrm{~mL}$ of DNFB was dissolved. Approximately $0.1 \mathrm{~g}$ of the reducing enzyme (hydrogenase or cytochrome $\mathrm{C}$ ) was then introduced to this mixture and allowed to react anaerobically in a shake flask for $1 \mathrm{~h}$ at ambient temperature. The resulting yellow precipitate was successively washed with $10 \mathrm{~mL}$ of an aqueous solution of sodium dithionite $(5 \mathrm{mg} / \mathrm{ml})$ to maintain the enzyme in a reduced state, $10 \mathrm{~mL}$ of ethanol, and $10 \mathrm{~mL}$ of diethyl ether. The solids were then dried under a N2 atmosphere and stored in a stoppered container at $4^{\circ} \mathrm{C}$. This solid product was the dinitrophenyl (DNP) derivative of the crude enzyme.

Each type of the DNP-enzyme derivative, DNP-cytochrome and DNP-hydrogenase, was tested for benzene solubilization by introducing $50 \mathrm{mg}$ of the dried material into $10 \mathrm{~mL}$ of dry benzene. After $1 \mathrm{~h}$ of contact in a shake flask operating at $100 \mathrm{rpm}$ under a N2 atmosphere at ambient temperature, the absorbance of the benzene solution was measured as an indication of solubilization. In both cases, the results were compared to a reference test in which the DNFB precipitate in the absence of protein was used. There was considerable solubilization of the modified protein with an estimate of greater than $1.2 \mathrm{mg} / \mathrm{ml}$ for the DNP-hydrogenase and $1.8 \mathrm{mg} / \mathrm{ml}$ for the DNP-cytochrome. This promises to be an interesting new approach to enzyme solubilization in organics and it will be further investigated.

\subsection{Benzene Solubilization of Membrane-Bound Hydrogenase}

A major portion of the hydrogenase enzyme in $P$. vulgaris apparently bound to the cell membrane. As such it is probably in a chemical form that is relatively hydrophobic. Previously, the hydrogenase was removed from the membrane and solubilized in an aqueous buffer by deoxycholate.

It was decided to isolate membrane fragments with attached hydrogenase and determine the degree of solubilization in benzene without additional chemical modification. The microorganisms were harvested in the exponential phase, washed with distilled water, sonicated and then centrifuged for 30 minutes at $500 \mathrm{x} \underline{\underline{\mathrm{G}}}$. The isolated solids that were predominately membrane fragments were then slurried in $0.05 \underline{\mathrm{M}}$ phosphate buffer at a $\mathrm{pH}$ of 7.0 and stored for future use. 
Two different types of tests were made to determine the solubilization of the crude enzyme particles in benzene: (1) the slurry of crude hydrogenase was reduced by the addition of $5 \mathrm{mg} / \mathrm{ml}$ of sodium dithionite and an equal volume of benzene was added with contact in a shake flask at ambient temperature for $1 \mathrm{~h}$; and (2) the slurry was freeze-dried and $120 \mathrm{mg}$ of the resulting solids was added to $10 \mathrm{~mL}$ of benzene in a shake flask at ambient temperature with contact for $1 \mathrm{~h}$. The hydrogenase activity of the liquid slurry was 0.5 units $/ \mathrm{ml}$.

As indicated in Table 4.1-2, there was appreciable protein (enzyme) solubilization in the benzene as determined by absorbance measurements at 280 run. Unfortunately, this crude enzyme product also contains appreciable quantities of other proteins and membrane components. But, the apparent solubilization of membrane-bound components could provide a useful basis for future approaches to enzyme modification.

\subsection{Degradation of a Model Compound}

The model compound, 1,2-Bis(4-Quinolyl)-Ethane, has been used in preliminary tests for the activity of the DNP-enzyme in benzene. Three different tests were maris in which dissolved DNP-cytochrome, DNP-hydrogenase, and a mixture of the two modified enzymes in benzene were in contact with $1 \mathrm{mg} / \mathrm{ml}$ of the model compound under a $\mathrm{H}_{2}$ atmosphere at $300^{\circ} \mathrm{C}$ for $4 \mathrm{~h}$. A reference test was also made in which there was no enzyme present. As in previous tests with the PEG-modified enzymes, there was a definite enhancement of degradation of the model compound when the enzyme was present with the maximum effect occurring when both proteins were present (See Table 4.1-3). Since cytochrome $C$ is supposed to have limited catalytic activity but is primarily an electron carrier or hydrogen donor, the enhancement of hydrogenase activity with cytochrome present may indicate that the hydrogenase is utilizing the hydrogen donor property of cytochrome as well as the molecular hydrogen.

\subsection{Coal Solubilization Tests}

Although the major research effort continues to be the enhancement of enzyme solubilization in organic solvents, periodic tests have also been made on the solubilization of bituminous coal (Illinois \#6). As before, it was shown that the solubilized enzymes clearly enhanced the dissolution or conversion of coal in benzene when carried out at $30^{\circ} \mathrm{C}$ under a hydrogen atmosphere. This was true for the membrane-bound hydrogenase and for DNP-hydrogenase, DNP-cytochrome, and a combination of both modified enzymes 
(Table 4.1-4). The most significant effect was again when both hydrogenase and cytochrome $\mathrm{C}$ were present.

\subsection{References}

1. F. Sanger, Biochem. J. 45, 563 (1949).

\subsubsection{Future Work}

\subsubsection{Anaerobic Microbial Coal Conversion}

Future work will focus on the continued characterization of Argonne premium coal culture $5-2$, with particular emphasis on the demonstration of ring cleavage activity and detection of useful aliphatic end products. Cultures will be manipulated to channel metabolic flux toward alcohol production, probably by introduction of alcohologenic species into the microbial consortium.

\subsubsection{Enzymatic Solubilization of Coal}

The two new techniques for the enhanced solubilization of enzymes in organic media will be further tested. The more fundamental aspects of this approach for a wide range of enzymes will be investigated in the program on "Fundamental Bioprocessing Research for Coal Applications," while the focus in this project will be on the interactions of such catalytic systems with well-defined coal and model compounds.

\subsection{MILD GASIFICATION PRODUCT CHARACTERIZATION - R. L. Graves}

\subsubsection{Background}

Mild gasification of coal has been shown to be capable of producing relatively light liquids, possibly suitable as engine fuel, and char that may be suitable for boiler fuel or other uses. Process conditions greatly influence the product qua , nd, in particular, liquid product quality often suffers if high yields are sought. In this investiga liquid and char products will be characterized such that their qualities can be related back to processing conditions, coal type, etc. The characterization includes investigating the combustion properties of the products in addition to laboratory analyses. 
Table 4.1-2. Benzene solubilization of membrane-bound hydrogenase ${ }^{a}$

\begin{tabular}{lcc}
$\begin{array}{c}\text { Description of } \\
\text { enzyme preparation }\end{array}$ & $\begin{array}{c}\text { Absorbance } \\
(280 \mathrm{~nm})\end{array}$ & $\begin{array}{c}\text { Approximate } \\
\text { concentration }(\mathrm{mg} / \mathrm{mL})\end{array}$ \\
\hline Aqueous slurryb & 0.81 & 0.7 \\
Freeze-dried solidsc & 0.46 & 0.4 \\
\hline aTests were made with 10 $\mathrm{mL}$ of benzene in a $25-\mathrm{mL}$ shake flask \\
operating at $100 \mathrm{rpm}$ and ambient temperature under a $\mathrm{N}_{2}$ atmosphere. \\
b10 mL of a slurry of the crude membrane-bound hydrogenase (20 \\
mg/mL) in 0.05 M phosphate buffer (pH=7.0) contacted the benzene for 1 \\
$\mathrm{~h}$ followed by centrifugation at $500 \mathrm{x}$ for 15 min and recovery of the \\
benzene phase. \\
c120 mg of freeze dried crude membrane-bound hydrogenase was \\
added to the benzene for $1 \mathrm{~h}$ followed by centrifugation at $500 \mathrm{x}$ for \\
15 min and recovery of the liquid.
\end{tabular}

Table 4.1-3. Enzyme-enhanced degradation of 1,2-Bis(4-Quirvit) 1)-Ethane after $4 \mathrm{~h}$ in benzene at $30^{\circ} \mathrm{C}^{\mathrm{a}}$

\begin{tabular}{lc}
\hline \multicolumn{1}{c}{ Enzyme } & $\begin{array}{c}\text { Decrease in } \\
\text { absorbance } \\
(280 \mathrm{~nm})\end{array}$ \\
\hline Reference with no enzyme & 0.002 \\
$1.2 \mathrm{mg} / \mathrm{mL}$ DNP-hydrogenase & 0.012 \\
$1.8 \mathrm{mg} / \mathrm{mL}$ DNP-cytochrome C & 0.029 \\
DNP-hydrogenase + DNP-cytochrome C & 0.036 \\
\hline aAll tests were made with a mixture of $10 \mathrm{~mL}$ benzene \\
containing 1 $\mathrm{mg} / \mathrm{mL}$ of the model compound in a 25 -mL shake \\
flask operating at 100 rpm for 4 h.
\end{tabular}

Table 4.1-4. Enzyme-enhanced solubilization of Illinois \#6 coal in benzene at $30^{\circ} \mathrm{C}$ under a hydrogen atmosphere ${ }^{a}$

\begin{tabular}{lc}
\hline \multicolumn{1}{c}{ Enzyme } & $\begin{array}{c}\text { Increase in } \\
\text { absorbance } \\
(280 \mathrm{~nm})\end{array}$ \\
\hline Reference with no enzyme & 0.08 \\
Membrane-bound hydrogenase & 0.32 \\
DNP-hydrogenase & 0.22 \\
DNP-cytochrome C & 0.48 \\
DNP-hydrogenase + DNP-cytochrome C & 1.68 \\
\hline \multicolumn{2}{c}{ aAll tests were made with 50 mg of -200 mesh coal in } \\
10 mL of fluid in a 25-mL shake flask operating at 100 rpm. \\
Enzyme concentrations in the benzene were the same as those \\
shown in Tables 1 and 2.
\end{tabular}




\subsubsection{Progress for This Reporting Period}

During FY 1991 it was planned that the characterizations should focus on chars and liquids from the pilot plants at the following organizations:

- Western Research Institute (WRI)

- SGI International

- University of North Dakota Energy and Environmental Research Center (EERC)

- PAI Corporation

Due to contractual and technical delays, only samples from WRI and EERC were available during this reporting period, aside from several samples of an upgraded coal diesel fuel blending stock frum Coal Technology Corporation (CTC).

New samples of mild gasification liquids arrived in March 1991 from WRI. The samples were in two boiling ranges, IBP-42OF and 420720F. In order to make the samples more functional as diesel fuel, we carried out a caustic washing on a portion of the sample, with reasonable results. While in the Golden, Colorado area, R. L. Graves had visited AMAX to review activities on mild gasification. Bob McCormick recommended that ORNL continue investigations of the char combustion characteristics and liquid characteristics related to engine fuels. Although high-value char products were of immediate interest, the char as boiler fuel was probably of longer-term significance. Their continuing examination of WRI liquids led them to believe that the samples we received last year contained a high percentage of cresylic acids, very likely detracting from their combustion performance. These contaminants can be removed via caustic washing. We had additional discussions with WRI on their recommended procedure for caustic washing. The caustic wash carried out at ORNL was similar, but not identical, to that done by WRI. The washed liquids exhibited an approximate $40 \%$ improvement in ignition quality as compared to the as-received sample.

Coal Technology Corporation (CTC) provided samples of a caustic-washed, distilled Coalite liquid for an ignition quality test. They believe that similar liquids can be produced in their pilot plant when it becomes operational. As we understand, there were no non-coal components in the "midwash," as termed by CTC. These were the first coal liquid samples that we have investigated that, in neat form, would operate in our test engine. Apparent cetane numbers in excess of 40 were achieved with $40 \%$ midwash content in diesel fuel, and over $60 \%$ coal liquid still produced an apparent cetane ranking of 35 . 
In late FY 1990, chars from the Institute of Gas Technology and WRI had been evaluated in the Babcock \& Wilcox fixed bed reactor, but the data had not been reduced at ORNL. The data analysis to rank the combustion characteristics of the chars are being completed in FY 1991. 


\title{
5. COAL COMBUSTION RESEARCH
}

\author{
R. L. Graves
}

\subsection{TECHNICAL SUPPORT TO PETC-USAID COLLABORATIVE COAL PROJECTS - R. P. Krishnan}

\subsubsection{Objectives}

In response to the request from the Pittsburgh Energy Technical Center (PETC), the Oak Ridge National Laboratory (ORNL) is providing technical assistance in the implementation of collaborative coal projects under the U.S. Agency for International Development (USAID)/Government of India (GOI) Phase II, Alternative Energy Resources Development (AERD) Project.

\subsubsection{Background}

In May 1983, the GOI and the USAID initiated the AERD project with a coal conversion component comprising of six collaborative coal projects.

1. Evaluation of freeboard performance in a fluidized bed combustor (FBC)

2. Scale-up of an atmospheric fluidized bed combustion boiler

3. Rheology, stability, and combustion of coal-water slurries

4 Beneficiation of fine coals in dense media cyclones

5. Hot gas cleanup and separation

6. Cold gas cleanup and separation

The PETC, USDOE under a Participation Agency Service Agreement (PASA) had the management responsibility for implementing the collaborative coal projects. In the $\mathrm{FBC}$ projects, ORNL and BHEL, Trichy, India, were designated as the lead institutions for the collaborative efforts.

The successful completion of the above coal projects in June 1987 led to a strong interest by the participants in the AERD coal conversion projects to continue the involvement of USAID and the USDOE in the following projects. 


\section{Project 1: Development of Pollution Control Strategies for Abatement of $\mathrm{NO}_{\mathbf{z}}$ and $\mathrm{SO}_{2}$} Emissions from Coal-Fired Power Plants

Nitrogen and sulfur oxide emissions from fossil-fired power plants are expected to increase significantly with the installation of additional coal-fired power plants in India. The composition and characteristics of Indian coals are different from U.S. coals and this will impact the selection of pollution control strategy. The existing data base in India on $\mathrm{NO}_{\mathbf{x}} / \mathrm{SO}_{2}$ emissions from coal-fired power plants is not adequate to quantitatively define the magnitude of the emissions, which is the first step in the evaluation of control options.

The objectives of this project are to establish the necessary data base on $\mathrm{NO}_{x} / \mathrm{SO}_{2}$ emissions by (1.) baseline monitoring in selected power plants in India using the state-of-the-art techniques de,veloped in the U.S.; (2) testing known in-furnace control strategies practiced in the U.S. in selected power plants in India; (3) bench-and pilot-scale testing of Indian coals to quantify $\mathrm{NO}_{x} / \mathrm{SC}_{2}$ emissions; and (4) imulation and modeling of the combustion and heattransfer processes in the boiler for $\mathrm{NO}_{\mathbf{x}} / \mathrm{SO}_{2}$ prediction.

The BHEL, Trichy, will carry out the projects in India as part of their ongoing research and development on $\mathrm{NO}_{\mathbf{x}} / \mathrm{SO}_{2}$ control from coal-fired power plants. Technical assistance from the U.S. will include identification and procurement of state-of-the-art equipment for $\mathrm{NO}_{\mathrm{x}} / \mathrm{SO}_{2}$ measurement, and training of the BHEL engineers in selected U.S. utilities (TVA and others) on $\mathrm{NO}_{x} / \mathrm{SO}_{2}$ monitoring and control technologies, and participation of U.S. experts in the existing bench-scale/pilot-scale testing activities at BHEL and in the baseline monitoring of Indian power plants.

\section{Project 2: Slagging Combustor Development for High-Ash Indian Coals}

Indian coals have ash content in the range of 35 to $50 \%$ and ash fusion temperature over $1482^{\circ} \mathrm{C}\left(2700^{\circ} \mathrm{F}\right)$. For coals of such high-ash content, it would be advantageous from the operational, reliability, and boiler life considerations if the ash can be successfully rejected as a molten slag rather than be allowed to carry over with the flue gas as in conventional pulverized fuel boilers. The slagging coal combustor has been developed along these lines and is now in the demonstration stage in the United States.

Recognizing the potential for this technology in India, the BHEL has an active research and development program under way. A 3.0 MW(t) process development unit has been erected and is in operation at Trichy. However, there are several fundamental and engineering issues that are yet to be resolved with respect to Indian coals (slagging potential, 
slag rejection - quantity and slag properties, ash carry-over from the combustor, optimum air preheat system, operating flexibility - startup, shutdown, and effect of design parameters on slag recovery and combustor operation, carbon utilization and $\mathrm{NO}_{\mathbf{x}} / \mathrm{SO}_{2}$ emissions) for commercial applications before the slagging combustor can be recommended for commercial applications.

The objectives of this project are to (1) demonstrate whether the slagging combustor technology is suited for Indian coals, (2) dentify the engineering problems associated with the design, operation and scale-up of the combustor, and (3) design modifications needed in the BHEL slagging combustor to conduct long duration test runs on a variety of Indian coals differing in ash content and slagging tendency.

U.S. technical assistance in the design review of the BEHL slagging combustor, screening and selection of Indian coals based on their slagging potential, and on-site participation in the testing and data analysis is envisaged.

\section{Project 3: Characterization of Indian Coals for Combustion and Gasification}

With the deteriorating quality of coal in India (highly erosive coal) coupled with fuel switching by utilities, there is a critical need to quantify the impact of coal quality on power plant performance. Pilot-scale combustion tests are mandatory to provide boiler performance data on combustion efficiency, fuel ignition characteristics, flame stabilization, slagging, fouling, erosion and corrosion of boiler components, and gaseous and particulate emissions. Pilot-scale tests are also necessary for the full-scale burning in commercial boilers. In India, there is no facility available to conduct screening tests on coal.

The objective of this project is to design, erect and commission a pilot-scale Fuels Evaluation Test Facility (FETF) at BHEL, Trichy, which will serve as a focal point for combustion research in India. The PETC combustion research division and the ORNL will be the lead U.S. institutions collaborating with BHEL, Trichy in this project.

\section{Project 4: Residual Life Assessment and Life Extension of Coal-Fired Power Plants}

The assessment of remaining life of coal-fired power plant components based on quantitative, nondestructive, real-time measurements of the extent of damage to these components is an area which is actively pursued in most advanced countries where the latest diagnostic tools are available. The methodologies and techniques are the key to a successful remaining life assessment program. In keeping with the need for steady and reliable electric 
supply, the Ministry of Power, Government of India has recently embarked on a multi-million dollar power plant life assessment and rehabilitation program.

This project will be a collaborative effort, initially between the BHEL and the Electric Power Research Institute (EPRI), in which the diagnostic techniques, design criteria, methodologies, and implementation strategies developed by EPRI for the U.S. utilities will be tested in selected Indian utilities. The highly erosive nature of Indian coals will pru vide an opportunity to test the engineering correlations for prediction of erosion of boiler and auxiliary components, and possibly extended their range of applicability

\section{Project 5: Environmental and Natural Resource Analysis of Coal Cycle}

The mining, conversion, and disposal of waste and byproducts from coal utilization have serious environmental repercussions in India. Although there are regulations stipulated for air and water quality pollutants, they are not strictly enforced except in urban areas. This policy is going to change in the near future, and several groups are working in the country on allowable limits, environmental considerations for power plant siting, and impact of air/water/soil quality in the vicinity of coal mines and coal burning facilities. In all these tasks, environmental system models and an environmental data base are vital. Air and water quality data are only now being collected in India, mainly around the large power plants in central India.

The goal of this project is to develop environmental system models for prediction of air and water quality near coal-based power plants. The present data base will only permit levelopment of the overall structure of the model and the process/environmental data needed as inputs for the system model. It is expected that the model can be refined as more data becomes available. The methodology and the model inputs and outputs will be established in this project.

The project will be carried out by the Tata Energy Research Institute (TERI), New Delhi. Assistance to TERI will be provided by ORNL, PETC, EPA in the screening, selection and adaption of the air/water quality prediction models developed in the U.S. for local conditions.

\subsubsection{Status Summary}

During this reporting period, the activities and accomplishments in each of the five coal projects are summarized below: 
1. In the $\mathrm{NO}_{\mathrm{x}} / \mathrm{SO}_{2}$ emissions assessment project, the planned monitoring of $\mathrm{NO}_{\mathrm{x}} / \mathrm{SO}_{2}$ at an Indian utility has not been possible because of the unavailability of $\mathrm{NO}_{\mathrm{x}} / \mathrm{SO}_{2}$ monitoring equipment in India. BHEL has carried out $\mathrm{NO}_{\mathbf{x}}$ measurement in $500 \mathrm{MW}$ and $200 \mathrm{MW}$ units employing a portable electrochemical flue gas analyzer (LANCOM Model 3400). This instrument does not meet the U.S. Environmental Protection Agency (USEPA) specifications for $\mathrm{NO}_{\mathrm{x}}$ measurements. $\mathrm{SO}_{\mathrm{x}}$ measurements have not been made in the $500 \mathrm{MW}$ and $200 \mathrm{MW}$ units. Oxygen, carbon monoxide, carbon dioxide and particulates have been measured, but the accuracy of the measurements is questionable.

The current test plan for the emissions monitoring includes measurement of $\mathrm{NO}_{\mathrm{x}}, \mathrm{SO}_{\mathrm{x}}$, $\mathrm{O}_{2}, \mathrm{CO}, \mathrm{CO}_{2}$, hydrocarbons and particulates in a $200 \mathrm{MW}$ tangential fired unit: Baseline monitoring will be carried out for a minimum of one week at high, medium and low steam loads will be attempted. The tests will be repeated under low- $\mathrm{NO}_{\mathrm{x}}$ producing operating conditions to determine the parameters having the most pronounced effect on $\mathrm{NO}_{\mathbf{x}}$

The monitoring techniques will consist of:

- Continuous emissions monitoring (CEM) system for online $\mathrm{NO}_{x}, \mathrm{CO}, \mathrm{CO}_{2}, \mathrm{SO}_{2}$ and $\mathrm{O}_{2}$ utilizing a multi-probe sampling grid for adequate coverage of duct crosssection with U.S. EPA approved monitors and gas conditioning system;

- Selected monitoring of total hydrocarbons (THC) using gas grab methods approved by the U.S. EPA;

- Selected measurements of Loss of Ignition (LOI) and unburnt carbon in the ash for thermal efficiency loss calculations, using grab particulate samples in the duct, upstream of the ESP. Collection of these samples will be based on U.S. EPA approved methods;

- Grab samples of coal test composites for laboratory proximate/ultimate analyses using standard ASTM sample collection and coal analyses methods.

The data from the $200 \mathrm{MW}$ unit will be analyzed to establish the pollutant levels under normal power plant operating conditions. A second series of tests in the $500 \mathrm{MW}$ unit will be conducted by BHEL and the Indian utility at a later date in consultation with the U.S. technical experts. Provision for concentric tangential firing and overfire air 
injection for $\mathrm{NO}_{\mathrm{x}}$ reduction are available in the larger units. These control options will be tested after the visit of the BHEL engineers to U.S. utilities and other installations, where in-situ methods for $\mathrm{NO}_{\mathrm{x}}$ reduction are under investigation.

To execute the test plan, all the necessary equipment will be required at the site in India. It appears now that the equipment will either have to be shipped from the U.S. on a loan basis, provided the power requirements are compatible to operate the equipment in India, or procured. To procure the equipment, additional funds will be needed (about $\$ 100,000$ ). PETC, ORNL, and BHEL are looking at the budgetary requirements and will be advising USAID and DNES on what is the most cost-effective option.

2. Approximately $\mathbf{3 0 0}$ hours of testing has been conducted in the BHEL slagging combustor at Trichy since it was commissioned in March 1989. Testing has been done on bituminous coal, a coal washery product and a lignite. These tests did result in some slag formation on the combustor walls but the quantity of slag produced and the thickness of the slag deposit were way below the design expectations. Tests have also been conducted with a fluxing agent to improve the slag fusion and slag flow properties. Some improvements were observed, particularly with lignite, but there is still a lot more developmental work required to optimize the design and operating conditions.

The agenda for future activities include modifications in both hardware and operating conditions to achieve continuous and uniform slag deposition and minimum slag carryover in the flue gas. Diagnostic tools will be incorporated in the combustor to monitor the slag formation, slag layer thickness and heat flux in the vicinity of the combustor walls. A U.S. technical expert will visit BHEL, Trichy in late 1991 to carry out a design review of the existing combustor and to suggest the modifications needed to improve the combustor performance. Two BHEL engineers will visit the U.S. for interaction and technical discussions with experts at PETC, Energy and Environmental Research Center, Brigham Young University, Solar Turbines, Argonne National Laboratory, Mountain States Energy, and the University of Tennessee Space Institute. A design review of the BHEL combustor will be attempted during the visit of the 
BHEL engineers. Testing on lignites will resume after the modifications are made to the combustor. A U.S. technical expert will participate in the testing at Trichy.

3. The design of the Fuel Evaluation Test Facility (FETF), the specifications of equipment for the FETF, and the general layout of the test facility have been completed. Process instrumentation and the data acquisition system for the FETF are yet to be specified. These tasks will be taken up after the location and frequency of sampling of the process and control parameters are finalized.

A design review of the FETF was completed at PETC in December 1990. Attendees included engineers from BHEL, Acurex, Gilbert-Commonwealth and the PETC coal combustion division staff. Two BHEL engineers were deputed for eight weeks in November-December 1990 to participate in the design review and in the combustion tests on two Indian coals which were carried out in the PETC fucls evaluation test facility. The combustion tests were intended to provide baseline data on flame stability, carbon burnout, emissions, and ash deposition. Characterization of the coal and ash samples and analysis of the test data are in progress. The information gathered in these tests was used to validate some of the critical design parameters selected for the FETF. In addition, the tests provided training and exposure to the BHEL engineers on start-up, shut-down, operations of the FETF, and the safety procedures for fireside performance testing.

The input data for calculating the loads and for preparing the final engineering drawings for the foundation, supports, platforms, columns, and the building have been prepared. BHEL is proceeding with the civil engineering activities. The foundation/structural drawings are scheduled to be released in March-April 1991. Site activities will commence thereafter. Fabrication drawings for the combustor and auxiliary components have also been taken up in parallel. The commercial boiler design group at BHEL is being consulted on a regular basis to ensure that the FETF design and the type of measurements envisioned in the FETF will be useful for the commercial boilers. The design group prefers using steam for the heat transfer fluid in the slag panels and waterwalls of the FETF rather than Dowtherm or ethylene glycol as is normally done in pilot scale units. The reason is that steam has an advantage that it is also the heat transfer medium in boilers. In addition, it is nontoxic unlike 
Dowtherm or ethylene glycol. A decision is pending on this issue at present because there is no steam source available in the vicinity of the proposed FETF site.

Concurrence of the BHEL management will be required to provide a dedicated steam supply source for the FETF since this would entail a substantial investment from BHEL. Measurements of in-situ ash emissivity, waterwall heat pick-up and thermal properties of the refractory and insulating material during furnace operation have been suggested by the boiler design group since they are extremely relevant and useful for the aesign of commercial boilers.

4. In the Power Plant Residual Life Assessment Project, the major accomplishments to date have been the visits of two EPRI technical experts and an EPRI consultant to BHEL, Indian utilities and power agencies. Through these visits, the current practices and methodologies used for prediction of remaining life of power plant components in the U.S. were communicated to the Indian engineers. Two seminars and two workshops were conducted in India with the participation of the Indian utilities, boiler vendors and power research agencies to disseminate the information. Equipment for this project has been finalized and procurement is underway.

Two BHEL engineers will be in the U.S. in May-June 1991 for four weeks. The purpose of the visit is to participate in an actual life assessment project at a U.S. utility and to get acquainted with the state-of-the-art techniques for in-situ oxide scale thickness measurement in boiler tubes, creep and fatigue analysis of thick-walled components, residual creep assessment, boiler and header life assessment and nondestructive techniques for creep and crack estimation. ORNL will coordinate the site visits and meeting with the U.S. institutions. Interpretation of the field data and predicting residual life from the field measurements will be stressed during the visit of the BHEL engineers. They will also attend the third conference on cycle chemistry and boiler tube failures organized by EPRI in the first week of June 1991.

A team of U.S. experts will participate in a life extension demonstration project with BHEL at an Indian utility which is tentatively planned for late 1991 or early 1992.

5. In the environmental modeling project with the Tata Energy Research Institute (TERI), the basic EPA air and water quality point source models were delivered to TERI in September 1990. Training of two TERI engineers on the use of these models 
has also been completed. Progress on the environmental system model has been slow because there is insufficient environmental emissions and meterological data. TERI is in the process of compiling the available data. It would require substantial investment of time and resources to develop the necessary data base to develop the system model. The current thinking is to continue these activities under the Global Environmental Center project which is to be initiated in the near future in India. Funding from USAID for the current project is not sufficient to complete the system model. Until additional funds are made available, no further activities are planned in this project. However, the data base efforts at TERI and the technical exchange of information with ORNL and other institutions in the U.S. will continue.

Dr. R. P. Krishnan, ORNL traveled to BHEL, Trichy in December 1990 to assist in the site activities. He participated in the project review meetings with USAID, GOI along with Dr. William C. Peters, PETC and the BHEL staff. A site-visit to the Central Power Research Institute (CPRI), Bangalore was made during this visit to assist CPRI with the formal proposal to USAID seeking technical assistance and training support for the coal projects to be carried out at the Thermal Power Research Center (TPRC) at Nagpur, India. CPRI has been given the responsibility to establish the TPRC by the Department of Power, Government of India. ORNL also participated in the discussion with BHEL, Trichy and the Industrial Credit and Investment Corporation of India (ICICI) on a proposed combined-cycle pressurized fluidized bed gasification pilot plant at BHEL, Trichy under the USAID Program for Acceleration of Commercial Enterprise (PACER). For details on these activities see ORNL Foreign Trip Report of R. P. Krishnan, ORNL/FTR-3858.

During the next reporting period, the site-activities at BHEL, Trichy on the FETF will continue. ORNL will be on-site assisting the BHEL engineers. BHEL engineers will visit U.S. institutions for discussions on the life assessment and slagging combustor projects. Shipment of the USAID equipment to Trichy will be initiated once the Government of India issues custom duty exemption to BHEL. This has taken considerable time and the BHEL management is pursuing the customs waiver for the USAID equipment at the highest levels in the Government of India. 


\title{
6. FOSSIL FUELS SUPPLIES MODELING AND RESEARCH
}

\author{
R. M. Lee
}

\subsection{STRATEGIC PETROLEUM RESERVE PLANNING AND MODELING - R. M. Lee, P. N. Leiby}

The SPR Planning and Modeling project submitted two reports to the Department of Energy. One concerned capital investments to allow more rapid withdrawals from the crude oil stockpile during emergencies. The other concerned the merits of a regional petroleum product reserve.

\subsubsection{Benefits of Alternative Drawdown and Distribution Capabilities for the Strategic Petroleum Reserve, January 31, 1991.}

The U.S. Strategic Petroleum Reserve (SPR) can be used to offset the effects of severe disruptions in the supply of oil. This study assessed the benefits of alternative SPR oil drawdown and distribution capabilities. Two models (DISSPR and ORNLTEIS) were used to compute the expected benefits, taking into account the probabilities of oil supply disruptions, the availability of other sources of supply to offset the disruption, the elasticities of oil demand, and other market parameters. Assuming disruptions of six months length or longer, for a 1 billion barrel reserve, expanding the drawdown and distribution capability beyond 5.5 million barrels per day may be unwarranted. With a 750 million barrel reserve, a 4.1 million barrel per day capability provides maximum benefits. These limits are determined by the rates at which the reserve would be exhausted over six months. After accounting for capital costs, somewhat lower capabilities may be optimal. These conclusions depend strongly on assumptions regarding the expected length of the disruption, and on the expectation that multiple large disruptions are unlikely (see Fig. 6.1-1).

\subsubsection{Estimating the Benefits and Costs of a Refined Petroleum Product Reserve, Revised Draft, January 31, 1991.}

The Refined Petroleum Product Reserve (RPPR) would be part of the Strategic Petroleum Reserve (SPR). There are two basic differences between an SPR and an RPPR -(a) the storage of products rather than crude oil and (b) regional vs. centralized location. Possible RPPR locations include New England, California, Hawaii, the U.S. Gulf area (co-located with the Strategic Petroleum Reserve). The key to assessing RPPR benefits is 
identifying and evaluating the advantage of its two special characteristics compared to what could be gained from the current crude oil SPR system. The primary analytical focus of this assessment was on the market benefits of an RPPR during a disruption. The disruptions considered were comparable to the extreme winter of 1989 (resulting in a distillate demand surge) and the Exxon Valdez accident (resulting in a gasoline shortage on the West coast). The benefits of a regional product reserve were estimated with a model of regional petroleum product markets. The RPPR provides special benefits only in short-term disruptions where the regional product market is especially isolated from other regions, and there is little opportunity for inter-product substitution. In general, the benefits are limited compared to the high cost of regional product storage.

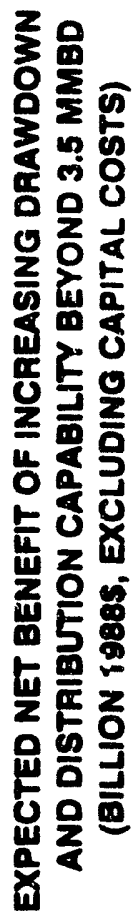

BENEFIT OF INCREASING DRAWDOWN AND DISTRIBUTION CAPABILITY

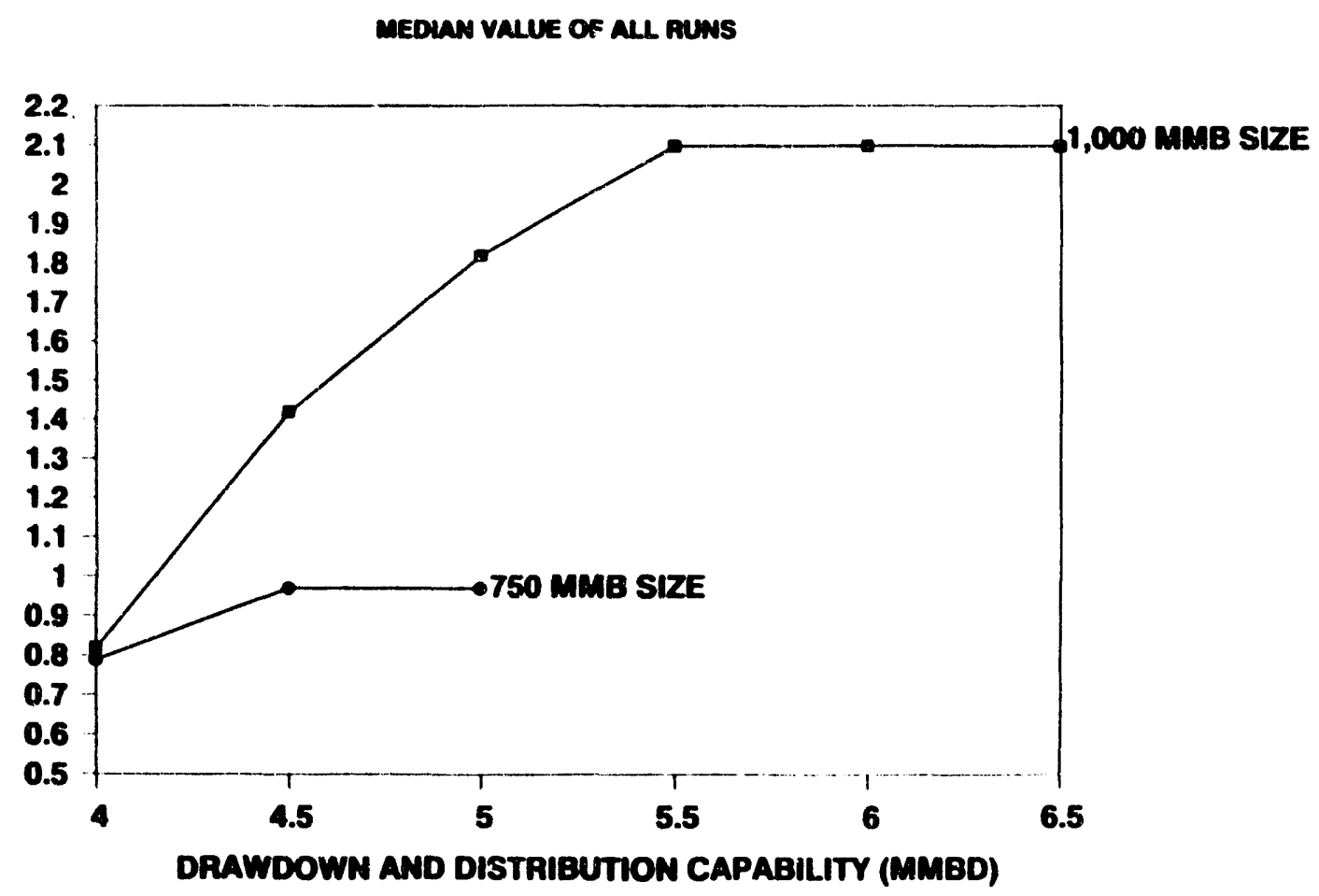

Fig. 6.1-1. Benefits of a regional product reserve drawdown. 


\title{
7. EVALUATIONS AND ASSESSMENTS
}

\author{
R. R. Judkins
}

\subsection{THE EXTERNAL COSTS OF FUEL CYCLES PROJECT - R. A. Cantor}

Fuel cycle cost analyses have become a subject of considerable interest in the U.S. and elsewhere as part of the process of producing, transforming, and using energy. More recently, efforts have been launched in the U.S., Canada, Indonesia, and within the United Nations to address the criticism that conventional fuel cycle assessments do not reflect damages to environmental and health resources. Many environmental costs associated with energy use are not fully reflected in the price consumers pay for energy services. The "uninternalized" costs, or externalities, ultimately impose a burden on society that arguably should be borne instead by energy consumers and producers. A number of state regulatory initiatives in the U.S. have been implemented to address the externalities of energy uses directly; however, resolving externality issues is confounded by the extremely complex nature of the problem. The U.S. Department of Energy (DOE) and the Commission of the European Communities (CEC) have entered into an agreement to conduct parallel studies in the U.S. and Europe on the external costs of fuel cycles. Oak Ridge National Laboratory (ORNL) and Resources for the Future (RFF) are the primary U.S. contributors to this multinational research effort.

The ORNL and RFF project seeks to develop the best range of estimates of external costs from secondary sources for the following fuels: oil, natural gas, coal, uranium, and renewables such as solar, biomass, hydroelectric, and wind. Conservation technologies will also be accommodated by the study to the extent that these technologies offer alternative strategies to capacity additions. The conservation technology areas to be explored include windows, lighting, appliances, and building shells.

Measuring the external costs for a specific energy fuel cycle involves two important components. First is the estimation of the quantities of all resources damaged by producing and consuming the fuel source, most importantly, the nonmarketed resources such as air and water quality. These physical damages represent the loss of resource quantities that fall outside the normal transactions in fuel cycle markets. The second component of measuring external costs involves the estimation of the opportunity costs of the used or damaged resource quantities. Opportunity costs reflect the value of goods and services foregone by 
applying resources to one use rather than alternative uses. Under generally competitive conditions and with incidental effects on nonmarketed resources, a value for the incremental use of a marketed resource can be directly observed as the market clearing price for this resource. In such cases, private costs can be interpreted to reflect social costs. However, there are instances where markets for energy resources in the U.S. fail to be generally competitive. Furthermore, energy production and consumption often affect nonmarketed resources significantly. For example, the production of energy from fossil fuels depletes resources associated with health and environmental quality. The opportunity costs, and very often the quantities of nonmarketed resources depleted from energy use, are not directly measurable. In these cases, the external costs must be estimated by physical relationships linking the production or consumption activity and damage to the nonmarketed resources, and from observations of individual valuations of these damaged resources within simulated or closely related markets.

There are three primary research objectives for the FY91 and FY92 funding of the external costs project:

1. To create a unified conceptual design for quantifying the various external costs associated with the production and consumption of energy from different fuel sources in the U.S;

2. To demonstrate an accounting framework that can be used to estimate the static measures of a broad range of external costs that result from incremental use of different fuel types and use this information in a comparative analysis of fuel types; and

3. To identify critical methodological issues and information needs that will affect any expanded efforts to develop comprehensive assessments of the social costs of energy use.

Project activities are divided into five phases over a 23-month time period. Phase 1 generates a research design to guide the separate assessment projects for the U.S., Europe, and any other international contributors. Phase 2 develops an accounting framework for the analysis of particular fuel cycles. The accounting framework provides the first-cut static assessment of resource impacts and attendant costs that arise from the incremental use of specific energy technologies. The framework will be applied to each of eight fuel types and four conservation options. Phase 3 considers how the accounting framework should be modified to provide a more realistic and dynamic assessment of fuel use choices. Various natural and economic models in the public domain will be investigated as possible contributors 
to linking physical and behavioral responses in an energy/economic/environmental model for future assessment efforts. Phase 4 identifies the critical issues and needs that emerge from the accounting framework analyses. A final report is prepared in Phase 5 that addresses the correspondence among this U.S. project and those of the international counterparts.

Following the initial stage of defining the project and receiving the funding to begin the project in FY91, the ORNL and RFF research team was identified and began activities. A planning meeting was held in Washington, D.C. with DOE and members of the CEC. Several position papers were prepared to resolve research questions that were raised at the meeting. A second meeting was held in Brussels which generated the need for additional position papers that were also prepared. A group of key contacts making up the U.S. team was identified and literature review activities completing Phase 1 and contributing to Phase 2 have been completed. A workshop was held on December 11, 1990 in Washington, D.C. for DOE program representatives to review the prepared position papers and to give ORNL and RFF feedback on the progress of the project so far.

As of June 30,1991, work has been completed on the paper matrices and the database architecture for the coal fuel cycle. These matrices have been reviewed internally and by DOE sponsors. A draft guidance document has been prepared for the paper matrices that uses the preliminary literature reviews of the natural and social science research to discuss the main parameters of the matrices and to guide a reader through the main analytical approaches to be used to fill in matrix cells.

ORNL and RFF expect to finish the coal, oil, natural gas, and biomass applications for electricity generation and oil and biomass applications for transportation by the end of 1991 . Additionally, we will complete all white papers in Phase 4. We expect to complete the rest of the fuel cycles and the conservation investments in the context of the scope of the Implementation Plan in the first six months of 1992 (some delay of schedule has been introduced to reflect the CEC time frame). Completion of the accounting matrices for all fuel cycles essentially completes Phase 2 of the project. The endpoints for Phase $3\left(E^{3}\right.$ model consideration), Phase 4 (critical issues and needs), and Phase 5 (comparison of counterpart studies and final report) will be in FY92. 


\subsubsection{Summary of Mectings and Documents Related to the External Costs of Fuel Cycles Project June, 1991.}

\subsubsection{Significant Mcetings:}

1. July $30-31,1990$, Washington, DC: Initial meeting of the steering committee to discuss the Implementation Plan and agreements for the parallel studies.

2. October $22-26$, Brussels, Belgium: This series of meetings with members of the CEC was undertaken to resolve some issues implied by pursuing parallel, coordinated studies; issues that were previously defined by the July meetings. In addition, it was an opportunity for some members of the U.S. research team and the DOE sponsor to meet with their European counterparts for the study, as well as persons in change of research areas that ultimately would play a key role in the European study.

3. November 13, Washington, DC: Meeting with DOE sponsor to discuss progress and plans for transferring information about the project to other interested parties.

4. December 11, Washington, DC: Workshop with representatives from DOE offices of FE, CE, NE, OEA, and EIA to get suggestions for the project and information about related work known to these offices.

5. January 28 - February 1, 1991, Oak Ridge TN: Meeting of the ORNL research team and Jacqueline Boucher, Project Manager, Coherence, Inc. and Nick Eyre, Technical Project Manager, Energy Technology Support Unit, UK Department of Energy.

6. February 4 - 6, Washington, DC: RFF and DOE Meetings with Jacqueline Boucher, Project Manager, Coherence, Inc. and Nick Eyre, Technical Project Manager, Energy Technology Support Unit, UK Department of Energy, Pierre Valette, Yves Smeers, and Phillippe Bordeau, Commission of the European Communities.

7. March 13 - 14, Oak Ridge, TN: Participation in two-day workshop on Natural Resource Damage Assessment for DOE Facilities.

8. March 19, Nashville, TN: Presentation by Alan Krupnick at VIPPS.

9. March 21, Knoxville, TN: Meeting with representatives from the Japanese Institute, RITE.

10. March 26, Oak Ridge, TN: Meeting with Hal Harvey of the Energy Foundation.

11. April 18, 1991, Raleigh, NC: Workshop on Emerging Environmental Policies and Business. Alan Krupnick presented the session of the externalities of energy production.

12. April 30, 1991, Baltimore, MD: Annual Meetings of the National Association of Environmental Professionals. Robin Cantor presented an overview paper on the project. 
13. May 23-24, and 28-29, Oak Ridge, TN: Technical briefings for the Japanese.

14. May 30-31, Oak Ridge, TN. Consultative meetings of the Steering Committee.

\subsubsection{Documents Prepared by ORNL and RFF:}

1. Implementation Plan for a Full accounting of the Fuel Cycle Costs, last revised 11/14/90.

2. The Accounting Framework, 10/15/90.

3. Selecting the Incremental Use of the Fuel Cycle and the Regional Reference Environments, 10/15/90.

4. Environmental Externalities, 11/8/90.

5. What Non-Environmental Externalities Should be Included in the Fuel Cycle Study?, $11 / 7 / 90$.

6. Intertemporal Discounting for the Fuel Cycle Social Cost Study, 11/8/90.

7. The Treatment of Construction Leadtime in the Accounting Framework, 11/5/90.

8. Foreign Trip Report of R. A. Cantor, R. B. Shelton, and A. J. Krupnick, 11/5/90.

9. The paper matrices to be used for the analysis of the coal fuel cycle, January 1991.

10. The Valuation of Environmental Externalities: Guidance Document, draft, February 1991.

11. Health Impacts Guidance Document for Coal, Draft, March 1991.

12. Definition of Ecological Impacts and Preliminary Literature Review, Draft, March 1991.

13. Beyond the Market: Recent Regulatory Responses to the Externalities of Energy Production, Draft, March 1991, a revised version was submitted to The Environmental Professional, May 1991.

\subsubsection{Documents Prepared by the CEC:}

1. Structure of the Accounting Framework -- Criteria for a Conception, 10/15/90.

2. Which Externalities Should Be Included in the First Project, 10/15/90.

3. Non-Environmental Externalities, 10/15/90.

4. Marginal Costs of Externalities, 10/15/90. 
5. Modeling and Accounting Framework in Social Costs: Some Comments, 10/15/90.

6. Relating the Accounting and the Modeling Frameworks, 11/30/90.

7. An Accounting Framework for the Environmental Costs of Energy, draft, January 1991.

8. Discussion paper on the stages of the coal fuel cycle for the analysis, January 1991.

9. Report on the 27 January 1991 - 7 February 1991 EC Team Visit to the US, February 1991.

7.2 ANALYTICAL ASSISTANCE AND ANALYSIS FOR THE STRATEGIC

PETROLEUM RESERVE - J. H. Stewart, Jr., T. R. Mueller, and W. R. Laing

Previous work on this project showed the preparation and analysis precision for eight analysis of five NIPER oil sub-samples. The sub-samples were prepared from the following crudes:
81SPR048
87SPR030
84SPR001
83SPR046
83SPR046

\author{
NPR No. 1, shallow \\ Isthmus, Mexico \\ Brent, North Sea \\ Zarzaitine
}
Maya, Mexico

After sub-sampling, the samples were digested by an open beaker procedure. Those samples were analyzed by ICP/OES (Inductively Coupled Plasma [excitation]/Optical Emission Spectrometry [detection]) and by graphite furnace atomic absorption spectrometry with a resulting precision of about $8 \%$ RSD for most of the metals of interest. Recoveries for the volatile elements, arsenic, selenium, phosphorus and tin were poor.

Subsequent work has been focused on improving the recoveries of As and Se as well as several other species, including $\mathrm{Sb}, \mathrm{Sm}$ and $\mathrm{P}$. Activity was further prioritized in three categories:

1. As, Ba, Be, Cu, Fe, Mg, Ni, P, Pb, Sb, Se, Sn, V, Zn

2. $\mathrm{Al}, \mathrm{Ca}, \mathrm{Cr}, \mathrm{Mo}, \mathrm{Mn}$

3. $\mathrm{Hg}, \mathrm{K}, \mathrm{Si}$

with group 1 having the highest priority.

In recent work we have evaluated two digestion procedures which are based on closed, pressurized dissolution techniques. A High Pressure Asher (HPA), developed by 
Dr. G. Knapp in Austria (see "American Laboratory", March 1986) uses five silica vials with pressure-release caps in a common containment vessel to achieve high pressure and high temperature. Samples of oil up to $0.3 \mathrm{~g}$ can be digested. A microwave dissolution apparatus, CEM Model MDS-2000, was used by personnel at the CEM Corporation to digest a second batch of samples. The CEM apparatus simultaneously prepares 12 individual oil samples, each approximately $0.5 \mathrm{~g}$ in weight.

The HPA-digested samples were analyzed by ORNL and K-25 laboratories by ICP/OES and at ORNL by inductively coupled plasma/mass spectrometry (ICP/MS). The microwave-digested samples were analyzed at ORNL by ICP/OES and ICP/MS techniques. Table 7.2-1 compares the recoveries achieved by these closed, pressurized analytical procedures with those obtained by open beaker digestion. Table 7.2-1 also compares percentage recoveries of elements obtained by two completely separate ICP/OES units, and a comparison of ICP/MS with ICP/OES spectrometry. Tables 7.2-2 and 7.2-3 illustrate the accuracy of the techniques when compared with certified reference values. Table 7.2-4 shows typical comparison results, obtained for the Maya crude. Full analytical data for all five NIPER specimens will be submitted in a progress report to the SPR Program Manager.

Concentrated nitric acid was used as the digestion medium for all of the recent samples. The analytical results show dramatically improved recoveries for As, Se, and $\mathrm{P}$. Some of the metals, particularly $\mathrm{Sn}$ and $\mathrm{Sb}$, may require a different dissolution medium to achieve $100 \%$ recoveries.

The data in the tables represents a single sample of each of the materials. Future work will include precision studies on additional subsamples of the NIPER crudes, and attempts to find a more suitable dissolution media for $\mathrm{Sb}$ and $\mathrm{Sn}$.

The initial performance of the ICP/MS technique has been even better than expected. The quantitation has been in excellent agreement with the ICP/OES, and the detection limits are improved by factors of 10 or more. This study shows that a repeatable blending technique, two specimen preparation techniques, and two viable, simultaneous, multielement analytical measurement techniques have been achieved. 
Table 7.2-1. Comparison of results for Conostan C-21 by three dissolution procedures and analysis by ICP/OE and ICP/MS

\begin{tabular}{|c|c|c|c|c|c|c|c|}
\hline \multirow{2}{*}{ Element } & \multicolumn{2}{|c|}{ Open Digestion ${ }^{1}$} & \multicolumn{3}{|c|}{ HPA-Closed ${ }^{2}$} & \multicolumn{2}{|c|}{$\begin{array}{l}\text { Microwave- } \\
\text { Closed }^{3}\end{array}$} \\
\hline & $\begin{array}{c}\% \\
\text { Recovery }\end{array}$ & $\%$ RSD & ORNL/ICP & $\mathrm{K} 25 / \mathrm{ICP}$ & $\begin{array}{l}\text { ORNL/ } \\
\text { ICP/MS }\end{array}$ & ICP & ICP/MS \\
\hline $\mathrm{Al}$ & 108 & 3.6 & 100 & 99 & 93.6 & 111 & 106 \\
\hline As & 26 & 8.3 & 99 & 99 & 80 & 100 & 100 \\
\hline $\mathrm{Ba}$ & 102 & 2.7 & 88 & 88 & 81 & 102 & 88 \\
\hline $\mathrm{Cd}$ & 101 & 3.6 & -- & -- & -- & -- & $\cdots$ \\
\hline $\mathrm{Cr}$ & 105 & 5.0 & 104 & 101 & 94 & 111 & 103 \\
\hline $\mathrm{Cu}$ & 99 & 4.0 & 102 & 106 & 96 & 107 & 102 \\
\hline $\mathrm{Mg}$ & 104 & 3.8 & 101 & 100. & 92 & 107 & 102 \\
\hline $\mathrm{Mn}$ & 98 & 16 & 106 & 107 & 104 & 111 & 107 \\
\hline Mo & 101 & 3.2 & 83 & 88 & 84 & 110 & 104 \\
\hline $\mathrm{Ni}$ & 102 & 1.9 & 102 & 103 & 98 & 109 & 102 \\
\hline $\mathrm{P}$ & 21 & 34 & 100 & 86 & 63 & 102 & 100 \\
\hline $\mathrm{Pb}$ & 110 & 3.0 & 101 & 100 & 98 & 111 & 102 \\
\hline $\mathrm{Se}$ & 7.2 & 64 & 99 & 105 & 89 & 100 & 92 \\
\hline $\mathrm{Sn}$ & 52 & 2.0 & 52 & -- & 46 & 38 & 45 \\
\hline V & 104 & 1.9 & 100 & 100 & 92 & 107 & 101 \\
\hline $\mathrm{Zn}$ & 112 & $5: 1$ & 106 & 103 & 97 & 108 & 103 \\
\hline
\end{tabular}

'Work of April 1989

${ }^{2}$ High Pressure Asher, Rep. Amer. Laboratory, March 1986

${ }^{3}$ Microwave Digestions by Sara Littau, CEM Corp. 
Table 7.2-2. Conostan C-21

\begin{tabular}{|c|c|c|c|c|c|c|}
\hline & \multirow[b]{2}{*}{ Reference } & \multicolumn{3}{|c|}{$\begin{array}{c}\text { High Pressure/High Temperature } \\
\text { Dissolution }\end{array}$} & \multicolumn{2}{|c|}{ Microwave Dissolution } \\
\hline & & ORNL/CP & K25/ICP & $\begin{array}{c}\text { ORNL } \\
\text { ICP/MS }\end{array}$ & ORNL ICP & $\begin{array}{l}\text { ORNL } \\
\text { ICP/MS }\end{array}$ \\
\hline As & .. & $<8.4$ & $<8.4$ & $<0.48$ & $<61$ & $\begin{aligned}<.6 \\
<1.2\end{aligned}$ \\
\hline $\mathrm{Ba}$ & 900 & 790 & 790 & $\begin{array}{l}745 \\
717\end{array}$ & 920 & $\begin{array}{l}801 \\
779\end{array}$ \\
\hline $\mathrm{Be}$ & -. & 0.66 & 1.2 & $0.16_{4}$ & 0.74 & $\begin{array}{l}<.18 \\
<.35\end{array}$ \\
\hline $\mathrm{Cu}$ & 900 & 920 & 950 & 862 & 960 & $\begin{array}{l}932 \\
886\end{array}$ \\
\hline $\mathrm{Fe}$ & 900 & 780 & 770 & 578 & 1000 & $\begin{array}{l}912 \\
813\end{array}$ \\
\hline $\mathrm{Mg}$ & 900 & 910 & 930 & 824 & 960 & $\begin{array}{l}899 \\
943\end{array}$ \\
\hline $\mathrm{Ni}$ & 900 & 920 & 930 & 885 & 980 & $\begin{array}{l}935 \\
899 \\
\end{array}$ \\
\hline $\mathbf{P}$ & 900 & 900 & 770 & $\begin{array}{l}557 \\
579\end{array}$ & 920 & 907 \\
\hline $\mathrm{Pb}$ & 900 & 910 & 900 & 886 & 1000 & $\begin{array}{l}936 \\
897\end{array}$ \\
\hline Sb & $-\cdot$ & $<8.4$ & $<8.4$ & 0.04 & $<61$ & $\begin{array}{l}<.58 \\
<1.2\end{array}$ \\
\hline $\mathrm{Se}$ & -- & 13 & $<8.4$ & $0.10_{4}$ & $<61$ & $\begin{array}{l}<.58 \\
<1.2\end{array}$ \\
\hline $\mathrm{Sn}$ & 900 & 470 & NA & $\begin{array}{l}412 \\
416 \\
\end{array}$ & 340 & $\begin{array}{l}315 \\
488 \\
\end{array}$ \\
\hline V & 900 & 900 & 900 & 828 & 960 & $\begin{array}{l}934 \\
879\end{array}$ \\
\hline $\mathrm{Zn}$ & 900 & 950 & 930 & 875 & 970 & $\begin{array}{l}939 \\
916\end{array}$ \\
\hline Al & 900 & 900 & 890 & $\begin{array}{l}846 \\
838 \\
\end{array}$ & 1000 & $\begin{array}{l}986 \\
921 \\
\end{array}$ \\
\hline $\mathrm{Ca}$ & 900 & 910 & 970 & NA & 910 & NA \\
\hline $\mathrm{Cr}$ & 900 & 940 & 910 & 844 & 1000 & $\begin{array}{l}959 \\
900\end{array}$ \\
\hline Mo & 900 & 750 & 790 & 7.57 & 990 & $\begin{array}{l}967 \\
898 \\
\end{array}$ \\
\hline $\mathrm{Mn}$ & 900 & 950 & 960 & 933 & 1000 & $\begin{array}{l}992 \\
929\end{array}$ \\
\hline $\mathrm{Si}$ & 900 & 1100 & 1300 & NA & 920 & -- \\
\hline
\end{tabular}

NA $=$ Not Analyzed

All values reported in micrograms of element/gram of specimen 
Table 7.2-3. NIST Crude (NBS 1634b)

\begin{tabular}{|c|c|c|c|c|c|c|}
\hline & \multirow{2}{*}{$\begin{array}{c}\text { NIST } \\
\text { Reference }\end{array}$} & \multicolumn{3}{|c|}{$\begin{array}{c}\text { High Pressure/High Temperature } \\
\text { Dissolution }\end{array}$} & \multicolumn{2}{|c|}{ Microwarve Dissolution } \\
\hline & & ORNL/CP & K25/1CP & $\begin{array}{l}\text { ORNL } \\
\text { ICP/MS }\end{array}$ & ORNL ICP & ORNL ICP/MS* \\
\hline As & $0.12 \pm .02$ & $<8.2$ & $<8.2$ & $<0.82$ & $<3.1$ & $\begin{array}{l}<.62 \\
<1.2\end{array}$ \\
\hline $\mathrm{Ba}$ & 1.3 & 3.9 & 4.0 & 3.55 & 3.8 & $\begin{array}{l}4.4 \\
5.3\end{array}$ \\
\hline $\mathrm{Be}$ & -. & 0.079 & 0.096 & $<.05$ & $<.019$ & $\begin{array}{l}<.007 \\
<.002\end{array}$ \\
\hline $\mathrm{Cu}$ & -. & $<1.1$ & $<.65$ & 0.82 & $<.44$ & $\begin{array}{l}0.61 \\
0.80\end{array}$ \\
\hline $\mathrm{Fe}$ & 32 & 32 & 32 & 22.1 & 32 & $\begin{array}{l}27 \\
31\end{array}$ \\
\hline $\mathrm{Mg}$ & -- & $<3.3$ & 2.7 & 2.67 & 2.3 & $\begin{array}{l}3.25 \\
3.61 \\
\end{array}$ \\
\hline $\mathrm{Ni}$ & $28 \pm 2$ & 28 & 29 & 28.9 & 23 & $\begin{array}{l}27.7 \\
27.4\end{array}$ \\
\hline $\mathbf{P}$ & -- & $<49$ & $<33$ & 4.15 & $<19$ & $\begin{array}{l}10.5 \\
13.8 \\
\end{array}$ \\
\hline $\mathrm{Pb}$ & 2.8 & $<8.2$ & $<8.2$ & 2.93 & 4 & $\begin{array}{l}3.0 \\
3.2 \\
\end{array}$ \\
\hline $\mathrm{Sb}$ & -. & $<8.2$ & $<8.2$ & $<.16$ & $<3.1$ & $\begin{array}{r}<.6 \\
<1.2 \\
\end{array}$ \\
\hline $\mathrm{Se}$ & $0.18 \pm .04$ & $<8.2$ & $<8.2$ & $<.16$ & $<3.1$ & $\begin{array}{r}<.6 \\
<1.2\end{array}$ \\
\hline $\mathrm{Sn}$ & - & $<8.2$ & NA & 0.074 & $<3.1$ & NA \\
\hline $\mathrm{V}$ & $55 \pm 1$ & 60 & 60 & 57.8 & 53 & $\begin{array}{l}53.2 \\
54.5\end{array}$ \\
\hline $\mathrm{Zn}$ & $3.0 \pm 0.2$ & 2.3 & 2.7 & 2.9 & 2.6 & $\begin{array}{l}4.9 \\
5.9\end{array}$ \\
\hline $\mathrm{Al}$ & 16 & 21 & 14 & 12.5 & 22 & $\begin{array}{l}28.7 \\
27.1\end{array}$ \\
\hline $\mathrm{Ca}$ & 15 & 7.2 & 16 & NA & 18 & NA \\
\hline $\mathrm{Cr}$ & 0.7 & 0.72 & 9.7 & 1.0 & 0.54 & 1.6 \\
\hline Mo & .. & $<6.5$ & $<1.6$ & 0.18 & $<2.5$ & $\begin{array}{l}<.1 \\
<.5 \\
\end{array}$ \\
\hline $\mathrm{Mn}$ & $0.23 \pm .03$ & 0.3 & 0.17 & $0.28_{5}$ & 0.15 & 0.3 \\
\hline $\mathrm{Si}$ & -- & 620 & 670 & - & 37 & .. \\
\hline
\end{tabular}

-Two dilutions of original sample

$\mathrm{NA}=$ Not analyzed

All values reported in micrograms of filemeni/gram of specimen 
Table 7.2-4. Maya Crude Oil

\begin{tabular}{|c|c|c|c|c|c|}
\hline & \multicolumn{3}{|c|}{$\begin{array}{c}\text { High Pressure/High Temperature } \\
\text { Dissolution }\end{array}$} & \multicolumn{2}{|c|}{$\begin{array}{l}\text { Microwave } \\
\text { Dissolution }\end{array}$} \\
\hline & ORNLICP & $\mathrm{K} 25 / \mathrm{ICP}$ & $\begin{array}{l}\text { ORNL } \\
\text { ICP/MS }\end{array}$ & ORNL ICP & $\begin{array}{l}\text { ORNL } \\
\text { ICP/MS }\end{array}$ \\
\hline As & $<9.6$ & $<9.7$ & $<.97$ & $<3$ & $<1$ \\
\hline $\mathrm{Ba}$ & $<.19$ & $<.19$ & 0.052 & 0.17 & 0.12 \\
\hline $\mathrm{Be}$ & 0.23 & 0.42 & 0.06 to $<.04$ & 0.1 & $<0.3$ \\
\hline $\mathrm{Cu}$ & 9.6 & 9.2 & 10.4 & 7.4 & 9.2 \\
\hline $\mathrm{Fe}$ & 13 & 11 & 3.00 & 7.9 & 7.7 \\
\hline $\mathrm{Mg}$ & $<3.9$ & 4.3 & 3.76 & 5.6 & 7.7 \\
\hline $\mathrm{Ni}$ & 59 & 61 & 56.6 & 50 & 57 \\
\hline $\mathrm{P}$ & $<58$ & $<39$ & 4.65 & $<18$ & 19 \\
\hline $\mathrm{Pb}$ & $<9.6$ & $<9.7$ & 0.79 & $<3$ & 0.13 \\
\hline $\mathrm{Sb}$ & $<9.6$ & $<9.7$ & $\begin{array}{l}.039 \\
.046\end{array}$ & $<3$ & $<0.3$ \\
\hline $\mathrm{Se}$ & $<9.6$ & $<9.7$ & 0.67 & $<3$ & $<.3$ \\
\hline Sn & 15 & $\mathrm{NA}$ & 12.8 & 3.5 & 0.6 \\
\hline V & 310 & 310 & 288 & 290 & 293 \\
\hline $\mathrm{Zn}$ & 1.1 & 3.3 & 4.39 to 5.99 & 1.1 & 3.7 \\
\hline $\mathrm{Al}$ & $<9.6$ & 7.2 & 2.63 & 7.6 & 7.4 \\
\hline $\mathrm{Ca}$ & $<1.9$ & 3.4 & $\mathrm{NA}$ & 8.1 & NA \\
\hline $\mathrm{Cr}$ & 2.1 & 13 & 2.2 & 0.98 & 2.1 \\
\hline Mo & 13 & 12 & $\begin{array}{l}11.2 \\
10.2\end{array}$ & 3.3 & 3.2 \\
\hline $\mathrm{Mn}$ & 0.35 & $<0.19$ & $\begin{array}{l}.102 \\
.646\end{array}$ & $<0.06$ & $<0.2$ \\
\hline $\mathrm{Si}$ & 1300 & 1300 & $\mathrm{NA}$ & 44 & NA \\
\hline
\end{tabular}

NA $=$ Not Analyzed

All values reported in micrograms of element/gram of specimen 


\section{COAL STRUCTURE AND CHEMISTRY}

\subsection{CHEMISTRY AND STRUCTURE OF COALS: METHODOLOGY FOR ASSESSING SURFACE AREA AND POROSITY FOR CARBONACEOUS MATERIALS UTILIZING INERT VAPOR SORPTION ISOTHERMS - \\ E. L. Fuller, JR.}

Many aspects of carbons and related materials are strongly dependent upon texture and morphology. Analyses of physical adsorption is an excellent method for evaluating the surface area and accessible (open) porosity. ${ }^{1}$ Inert gases adsorb on solid surfaces without specific (chemical) interactions and serve as excellent means to probe regions inaccessible by other techniques. Physisorption forms monolayers on solid surfaces which serve as the base for subsequent multilayer adsorption at higher pressures. Micropore $(<2 \mathrm{~nm})$ filling gencrally occurs at or below the pressures for monolayer formation. Various degrees of convolution give rise to mesopores $(2<100 \mathrm{~nm})$ responsible for additional condensation in the higher pressure regimes. Classical methodology involves analyses of the sorption isotherm akin to that presented in Figure 8.1-1 where the relative amounts of three (3) contributions vary for the specific morphology of the sample. The experimental isotherm is the composite sum of these processes and generally exhibits a shape akin to the uppermost sigmoidal curve. Our analyses involve assignment of the sorption to the three physical processes: (1) micropore filling of voids of less than $2 \mathrm{~nm}$ radii; (2) monolayer followed by multilayer buildup on any open surfaces; and (3) mesopore condensation governed by menisci with 2 to $100 \mathrm{~nm}$ radii. Chemisorption involves bonding to the substrate with much greater energy and will not be discussed here.

Previous works with coals have shown that the sorption processes are slow and complex, albeit very informative. These development studies were performed on cokes. These materials are more tractable in terms of their rigid structure, pore morphology, surface chemistry, volatile components, etc. Although the coke results are not truly representative of the surface properties of the coal precursors, they can serve as a comparative reference base. Cokes also provide excellent and definitive amounts of micropores and mesopores for methodology development, thus serving as ideal materials for development of methods, techniques, and theoretical interpretations.

The data used for this study were acquired with a computer controlled volumetric adsorption apparatus ${ }^{2}$ using nitrogen gas $(99.995 \%$ purity) at $77.2 \mathrm{~K}$. High purity gas is 
required if accurate meaningful data is needed at higher relative pressures. Saturation pressures were measured directly to enable accurate determination of high relative pressures. Equilibration times were those required to assure steady states (no sensible uptake of vapor within experimental error for extended periods of time as determined by the dedicated computer system). A typical isotherm for the coke materials used in this study required ca. $15 \mathrm{~h}$ for the range 0.001 to 0.995 relative pressure, $\mathrm{P} / \mathrm{P}(0)$. The isotropic coke sample is a production lot characteristic of commercial processes.

The experimental isotherm for nitrogen sorption at $77.2 \mathrm{~K}$ is presented as the uppermost curve in Figure 8.1-2. The qualitative relationship to Figure 8.1-1 is obvious and the methodology is straightforward for deducing the specific contributing components. Since the amount of sorption in the range up to $0.4 \mathrm{P}(0)$ is composed of both adsorption and persorption, the shape of the "knee" region is a more accurate measure of surface area per se. Most analyses measure the amount of uptake in this region as a measure of monolayer capacity. The autoshielding potential theory (ASP) of physisorption ${ }^{3}$ is more useful in this regard. The working form of the $\mathrm{ASP}$ equation relates sorption energy, $\epsilon=-\mathrm{RT} \ln [\mathrm{P} / \mathrm{P}(0)]$, to the coverage, $\theta$

$$
\frac{\epsilon}{R T}=\frac{\epsilon(*)}{R T} e^{-\theta}
$$

where the monolayer capacity is defined as

$$
\theta=\frac{\Gamma}{\Gamma(m)}
$$

where $\Gamma$ is the sorptive uptake measured in the experimental units (i.e., cc(STP)/gm), with $\Gamma(\mathrm{m})$ being the monolayer capacity in the same units. Appropriate algebraic transformations show that as seen in the graphical analysis of experimental data presented in rectilinear form in Figure 8.1-3.

$$
\Gamma(m)=\frac{d \Gamma}{d \ln (\epsilon / R T)}
$$

The horizontal line denotes the value of the monolayer on the same graph. The ASP parameters can be used to determine the extrapolated multilayer adsorption behavior defined 
YICROPORB, ADSORPTTON, NDD MRSOPORES

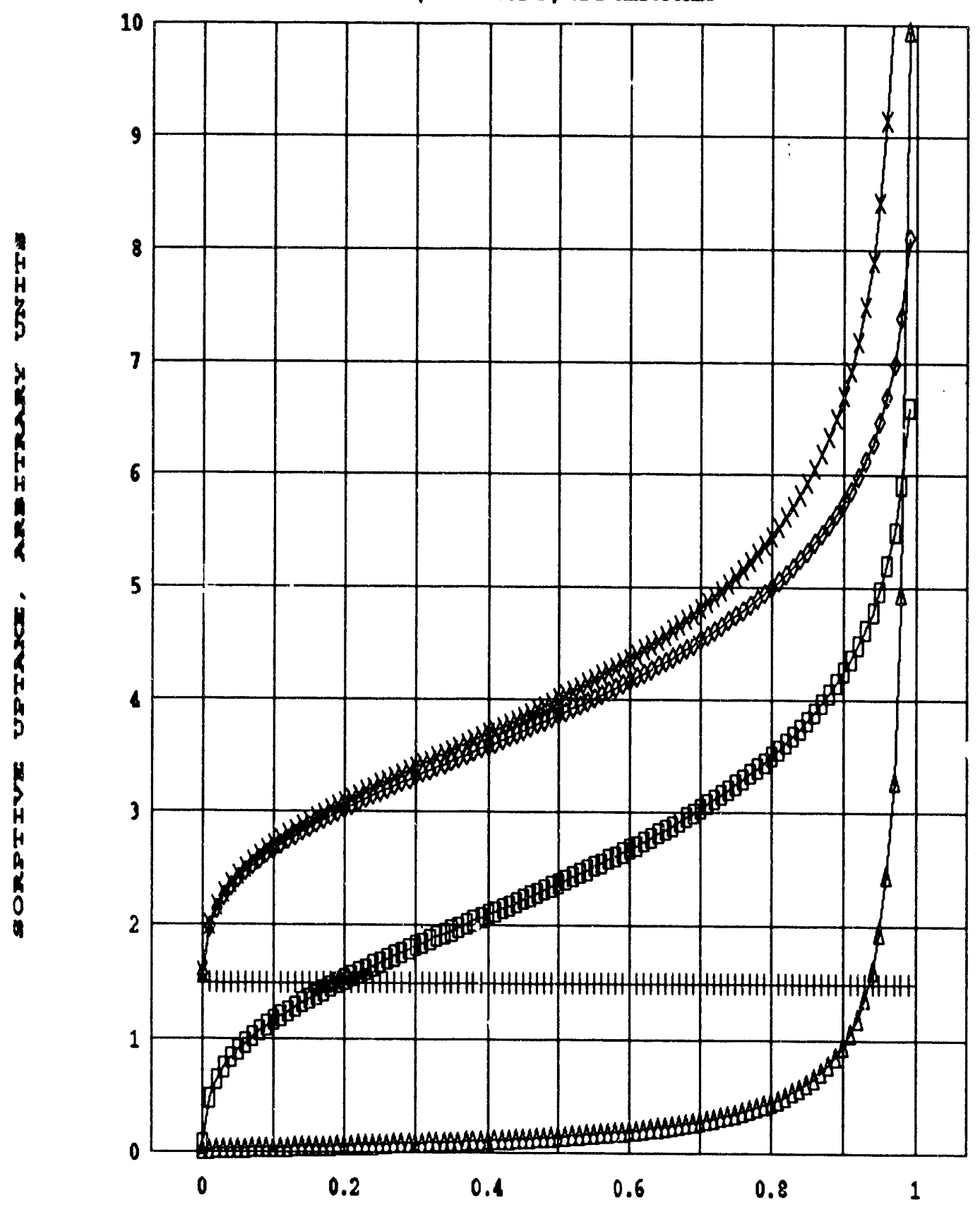

RETATTVB PRESSURE, $P / P(0)$

0 MULTILAYRR + MICROPORB 0 SOM $\triangle$ MRSOPCRE $X$ REALITY

Fig. 8.1-1. Schematic presentation of a typical sorption isotherm and its micropore, multilayer, and mesopore components. The upper sigmoidal curve depicts the overall effects noted in the composite experimental isotherm. 


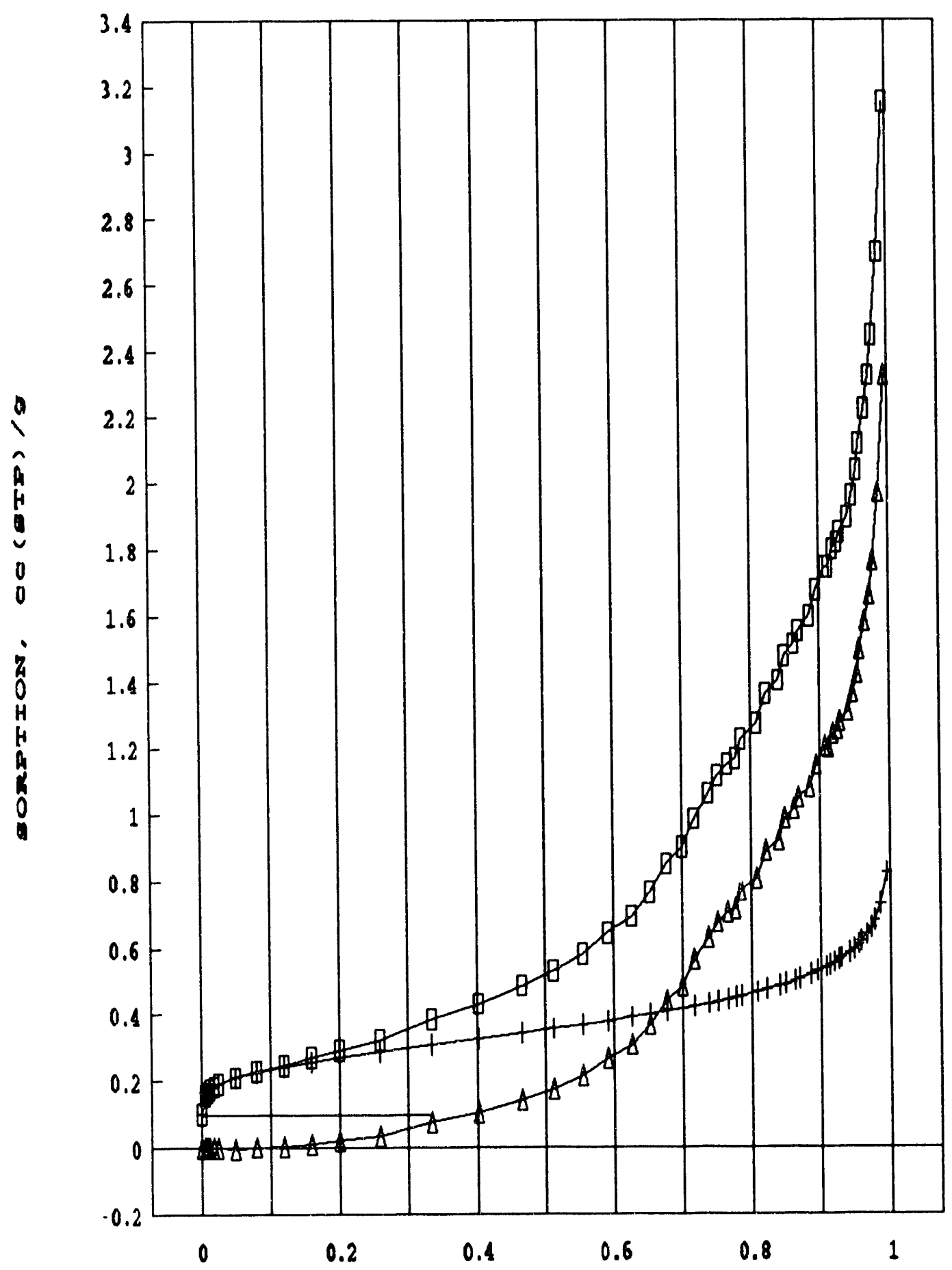

REATITVR PRESSURE, $P / P(0)$

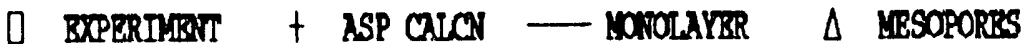

Fig. 8.1-2. Experimental sorption isotherm for nitrogenon coke A at $77.2^{\circ} \mathrm{C}$. Methods for separation into micropore filling, adsorption, and mesopore condensation is discussed in text. 
by the + points in Figure 8.1-2. Point by point graphical or numerical subtraction from the experimental isotherm is used to determine the mesopore contribution as noted as the lower curve in Figure 8.1-2 through the triangular point.

The mesopore distribution is readily related to the effective pore meniscus radii, $r(e)^{4}$

$$
r(e)=\frac{-\gamma V}{R T \ln [P / P(0)]}
$$

which for convenience can be expressed in nondimensional form, $-1 / 1 \mathrm{n}[-\mathrm{P} / \mathrm{P}(0)]$ and correlated experimentally as shown in Figure 8.1-4 for the initial stages of mesopore filling. This rectilinear form permits evaluation of the minimum pore size and the initial linear pore size distribution.

A more complete evaluation of the data is made, based upon the dimensionality of the inter- and intraparticulate pores where the dimensionality, D, is evaluated in terms of a power scaling law for the mesopore volume, $\mathrm{V}$ (meso), with respect to the effective radius:

$$
\begin{gathered}
V(\text { meso }) \propto \Gamma(\text { meso }) \propto r(e)^{D} \\
D=\frac{d \ln [\Gamma(\text { meso })]}{d \ln [r(e)]}
\end{gathered}
$$

This fractal dimension can be evaluated directly from the isotherm data as shown in Figure 8.1-5.

A synopsis of the results obtained in this study (Table 8.1) shows the amount of relevant data inherent in physisorption isotherms. To a first approximation, the BET method estimates the summation of the adsorption and micropores as reflected in the listed values. The complexity of the convolutions of mesopores is much greater for the smaller channels (intraparticulate(?), $\mathrm{D}=1.66$ ) than for the larger channels (interparticulate(?), $\mathrm{D}=0.27$ ). Details and substantiation of the interpretation of the results are being accrued from supporting microscopic analyses and related morphological techniques. The results are consistent, encouraging, and indicative that the inert gas sorption technique can and will supply valuable information related to the topology of carbonaceous substrates. 


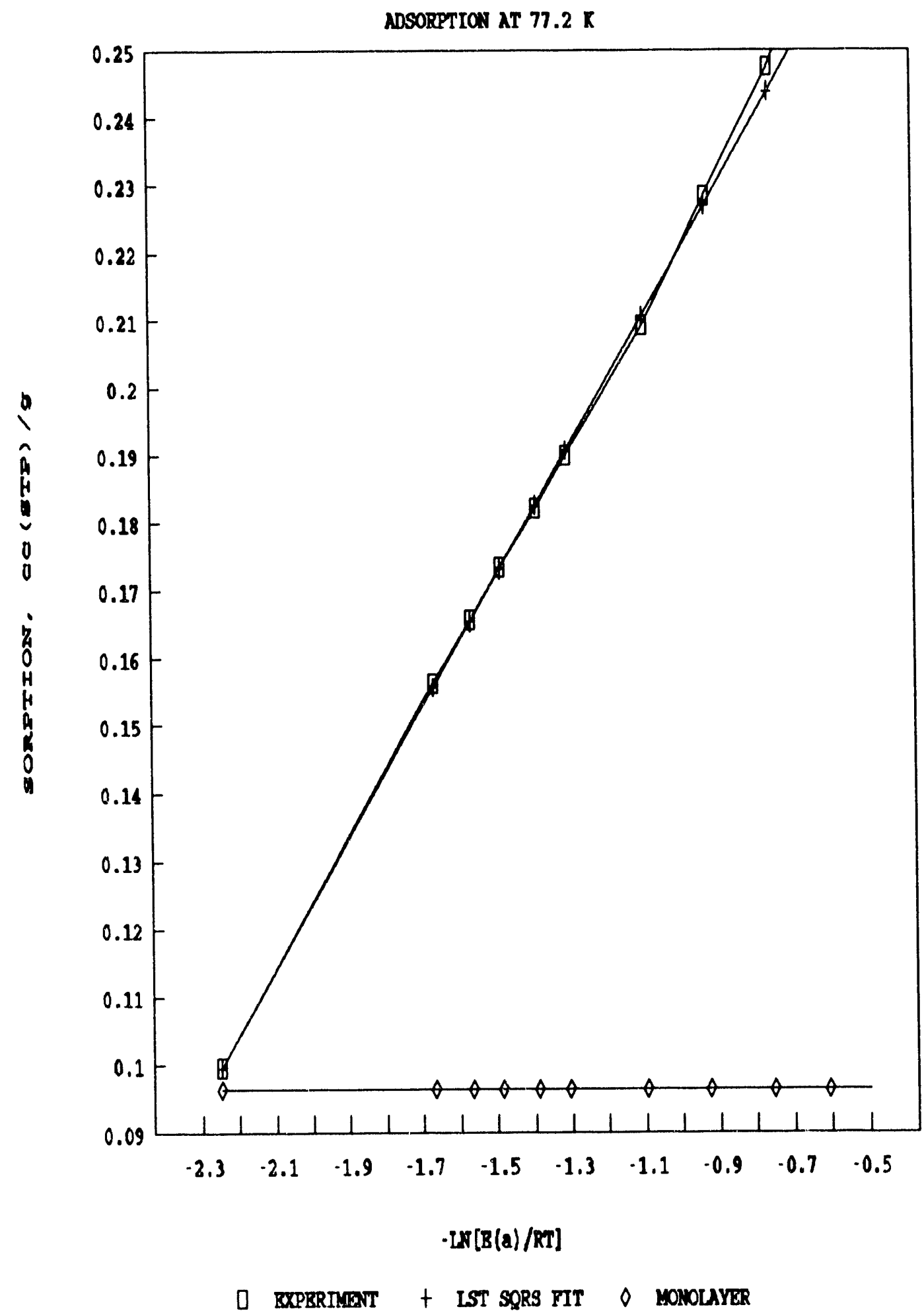

Fig. 8.1-3. Nitrogen adsorption evaluated in terms of the autoshielding potential theory. Fitted line through the data permits evaluation of the monolayer capacity and micropore capacity. 
SUkPlicu Al' $\% .2 \mathrm{x}$

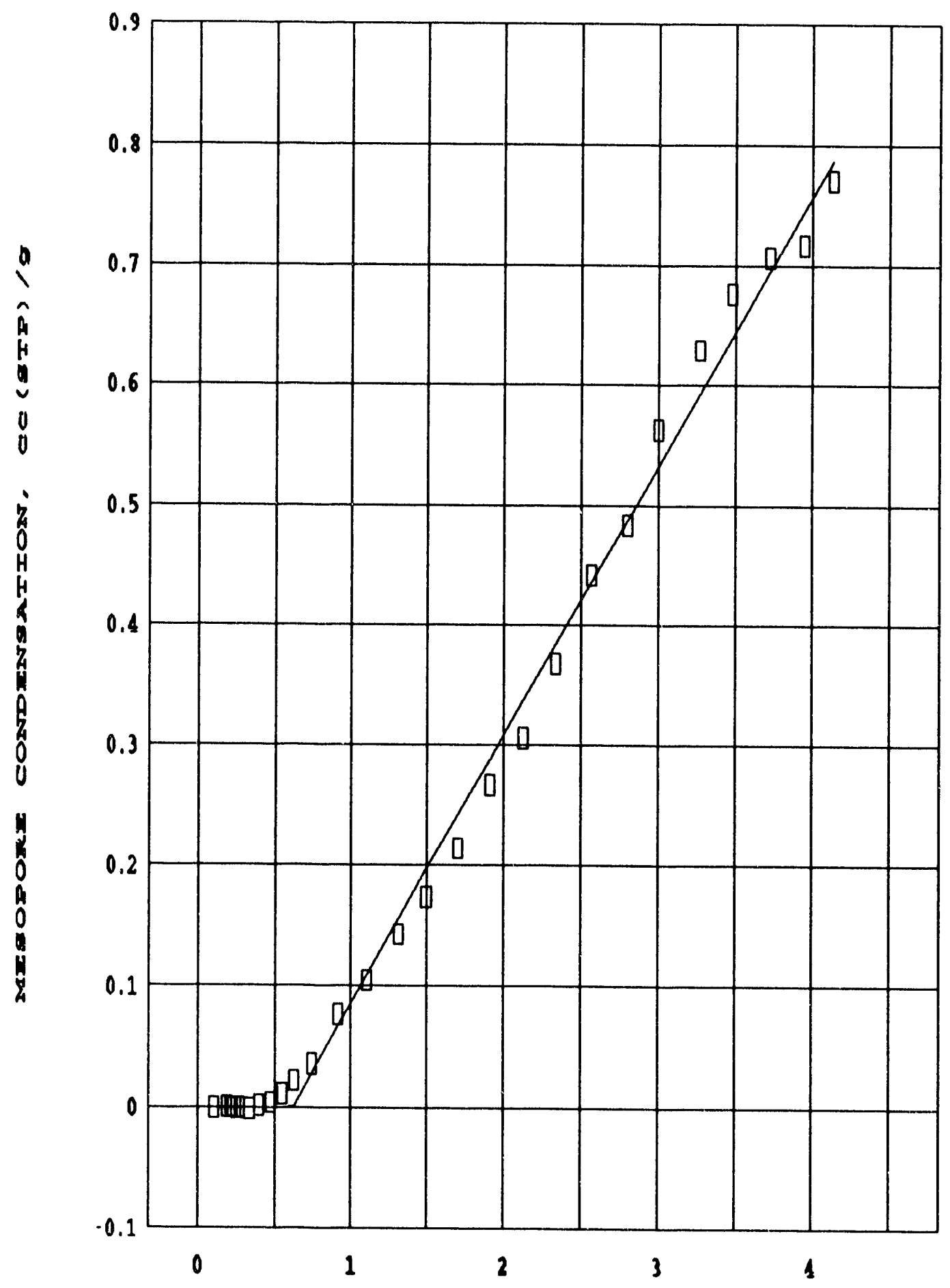

BPPBCTIVE RADIOS, DIMENSIONLRSS

(1) EXPMI - CLLOT

Fig. 8.1-4. Initial mesopore condensation on coke A showing a linear dependence on pore size. A minimum size is noted for inception of mesopore condensation. 


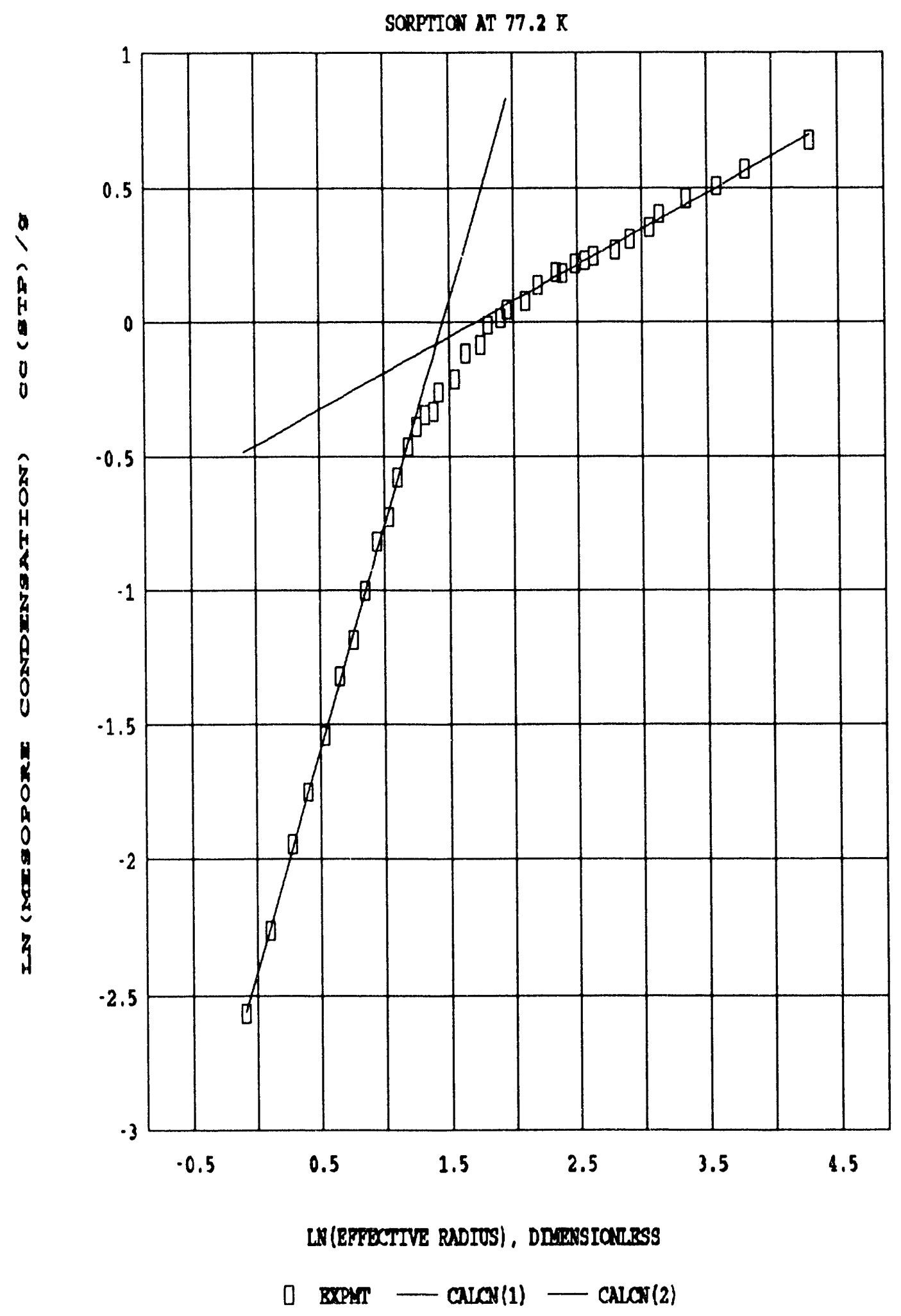

Fig. 8.1-5. Determination of mesopore fractal dimensions for coke A. Two distinctly linear regions exist, indicating two different pore morphologies. 
Table 8.1. Topological information derived from nitrogen sorption isotherm
$\epsilon(*) / \mathrm{RT}$
26.6
Monolayer Capacity(ASP)
$0.0964 \mathrm{cc}(\mathrm{STP}) / \mathrm{g}$
Micropore Sorption
$0.00925 \mathrm{cc}(\mathrm{STP}) / \mathrm{g}$
Monolayer Capacity(BET)
$0.2447 \mathrm{cc}(\mathrm{STP}) / \mathrm{g}$
C Constant(BET)
34.3
Effective Minimum Mesopore Size
0.614
Fractal Dimension(0)
1.0
Fractal Dimension(1)
1.659
Fractal Dimension(2)
0.269

\subsubsection{Conclusions}

Analyses of physisorption isotherms provide more important topological information for particulate surfaces than any other single technique. Detailed and cautious evaluation of this indirect method is required to assure definitive conclusions. Newer approaches allow distinct evaluation of pore morphology that is not inherent in classical treatments.

\subsubsection{References}

1. S. J. Greg and K. S. W. Sing, Adsorption, Surface Area, and Porosity, Cambridge University Press, 1967.

2. Micromeritics (Model 2600), Atlanta, GA.

3. E. L. Fuller, Jr., and J. B. Condon, "Statistical Mechanical Evaluation of Surface Area from Physical Adsorption Isotherms," Colloids and Surfaces, 37, 171 (1989).

4. A. W. Adamson, Physical Chemistry of Surfaces, Wiley, 1982.

\subsection{INVESTIGATION OF COAL SURFACES AND INTERFACES}

During this period, research on the analytical characterization of coal surfaces and interfaces between coal and various minerals continued. Analyses of the physical absorption of nitrogen gas on coal surfaces was performed utilizing a computer-controlled volumetric 
adsorption apparatus. Progress was made in the study of the oxidation of pyrite minerals (which are found in bituminous coals) using transmission electron microscopy (TEM) and $\mathrm{X}$-ray photoelectron spectroscopy (XPS).

8.2.1 Analytical Characterization of Coal Surfaces and Interfaces - Ted Nolan, Larry Allard, and Victor J. Tennery

Oxidation of pyrite in coals in one major source of sulfur dioxide emissions from coal combustion. This work includes study of the oxidation of pyrite minerals, with the objective of providing information on the mechanisms and kinetics of oxidation of pyrite crystals found in a large number of bituminous coals. Techniques have been developed to prepare thin foil specimens of these samples required for transmission electron microscopy (TEM). Thin foil specimens of naturally occurring pyrite single crystals and bulk samples of pyrite from coal seams have been prepared for TEM and surfaces analytical studies. Initial electron microscopy observations have permitted optimum conditions for sample preparation to be determined. We have found that large "single crystal" specimens of pyrite are typically polycrystalline and only a thin layer at the surface is actually single-crystalline. In spite of this, single crystal specimens suitable for both TEM and X-ray photoelectron spectroscopy (XPS) have been prepared. Further, it has been determined that the pyrite thin foils are stable in the environment of the electron microscope.

The objective of this task is to provide analytical characterization of coal surfaces and interfaces between coal and various minerals, particularly pyrite, for the purpose of assisting the Pittsburgh Energy Technology Center in its research on coal characterization and cleaning. This project includes the study of the chemistry and structure of coals including the properties of surfaces and interfaces. Particular emphasis is given to the chemical binding of the detrimental elements, including sulfur, nitrogen, mineral matter, etc. The distribution of these elements in various coals, and particularly the chemical and structural characterization of interfaces in coals are major tasks in the research. In addition, fundamental studies of the oxidation of pyrite and underway, to give information on ultrastructural changes related to mechanisms and kinetics of the oxidation process. Progress in the latter work is reported below.

Since pyrite is of major interest as a sulfur dioxide source during coal combustion, we have focussed major effort on first developing an understanding of the mechanisms of oxidation of this important mineral on a microscopic level. In this work, techniques of both TEM and surface analysis are used to characterize the microstructural and chemical changes 
which occur as pyrite single crystals gradually oxidize under controlled conditions. The TEM and surface analysis results are expected to be complementary, since the oxidation treatments are performed simultaneously on both the thin foil specimens necessary for TEM analysis and the bulk single crystals necessary for surface analysis by XPS.

Pyrite crystals, which have a cubic structure, typically grow as cubes having $\{100\}$ planar facets, octahedral having $\{111\}$ planar facets, or as "pyritohedra" having primarily $\{100\}$ and $\{210\}$ planar facets (Figs. 8.2-1 and 8.2-2) ${ }^{1}$. Accordingly, it is of interest of study the oxidation mechanisms of these three crystallographic surfaces. Since single crystal specimens of pyrite large enough for TEM and XPS are rare in coal deposits, other appropriate mineral specimens have been employed for the single crystal studies. These have been primarily cubes from Navarre, Spain and pyritohedra from Huanzala, Peru. The comparison to coal pyrite is being made utilizing polycrystalline pyrite specimens of suitable size from the Illinois \#6 coal.

First attempts at producing thin single crystal foils gave surprising results. Samples were prepared by slicing pyrite cubes appropriately to expose the required surface orientations. Thin foils prepared from these samples showed a fine-grained polycrystalline structure (Fig. 8.2-3), even though the bulk specimen had perfect facets typical of single crystal structures. Some single crystal specimens having a $\{100\}$ orientation and a size suitable for both TEM and XPS have been successfully prepared by slicing pyrite cubes so that the specimens were comprised of near-surface material (Fig. 8.2-4). These results are typical of those obtained from bulk pyrite specimens obtained from several different geographical locations. This suggests that only the very-near surface material on any pyrite crystal is actually single crystalline in nature, even though the pyrite form appears to be in the form of a macroscopic single crystal.

The TEM foils that are prepared utilizing a final step of ion-milling are typically contaminated with a minor growth of some compound that causes the faint polycrystalline rings seen in the inset diffraction pattern, and results in the mottled contrast seen in the image of the foil. An additional preparation step consisting of low voltage ion-milling for a short period of time with the ion beams adjusted to a very small incidence angle removes this extraneous material.

Characterization of $\{100\}$ cut foils both by TEM and XPS is to be completed in the next reporting period, which will be the last in this project. During this time the first oxidation experiments will be performed; the goal of these experiments is to determine the quantity of 
products formed at a given oxidizing condition in order to provide adequate products for the planned analyses.

\subsubsection{References}

1. L. G. Berry and B. Mason, Mineralogy, W. H. Freeman \& Co., p. 129 (1959). 
$\underset{n}{\sim}$

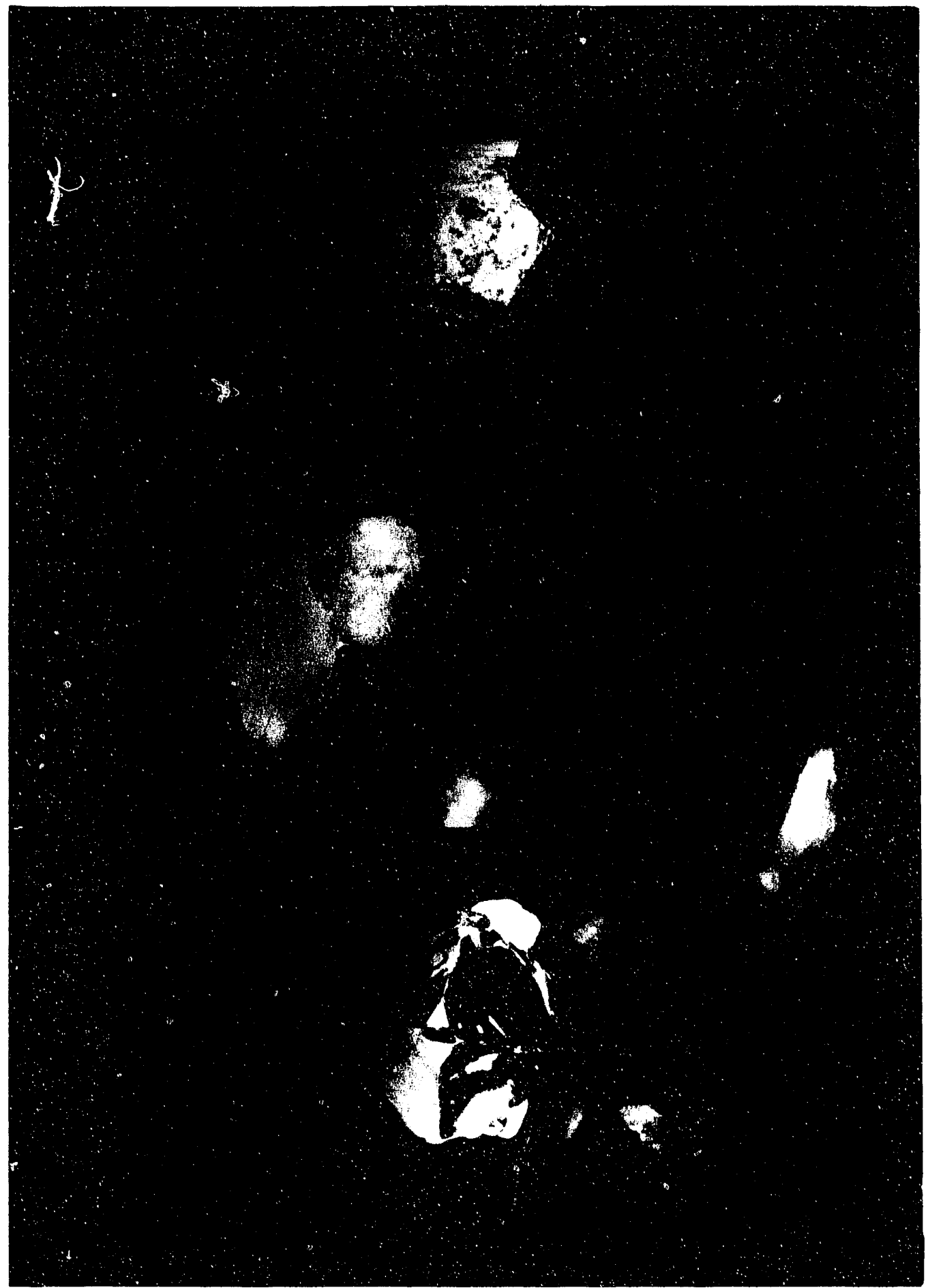

్ㅗㅇ

志

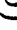

Зี

E

莺

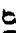

.

I

$\frac{n}{5}$

S

$\frac{0}{00}$

.

$\stackrel{\Perp}{.}$

등응

등

ஸे 일

$\infty$

$\infty$

至

高 


\section{ฟึ.}
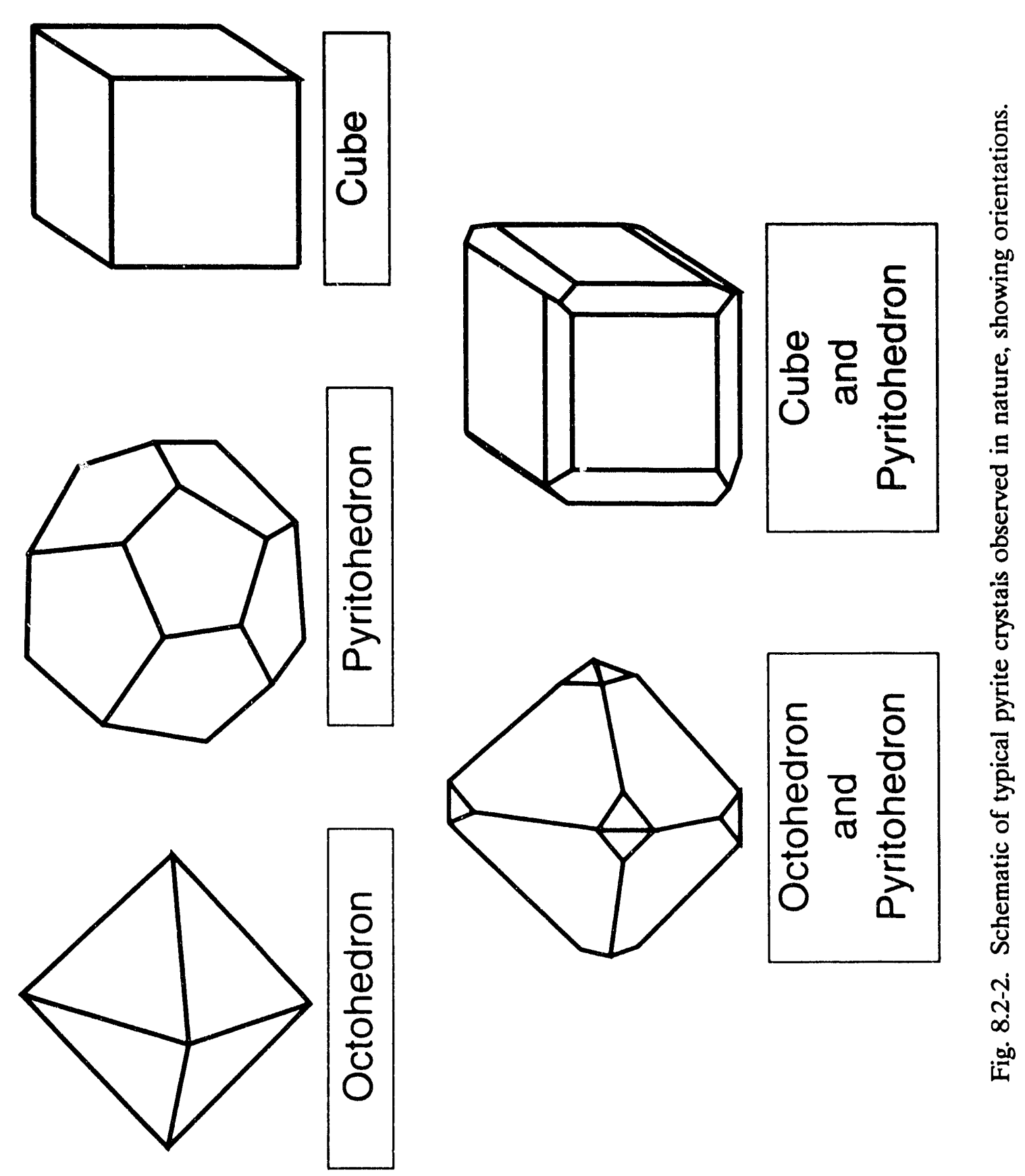

ஸे 
YP12934

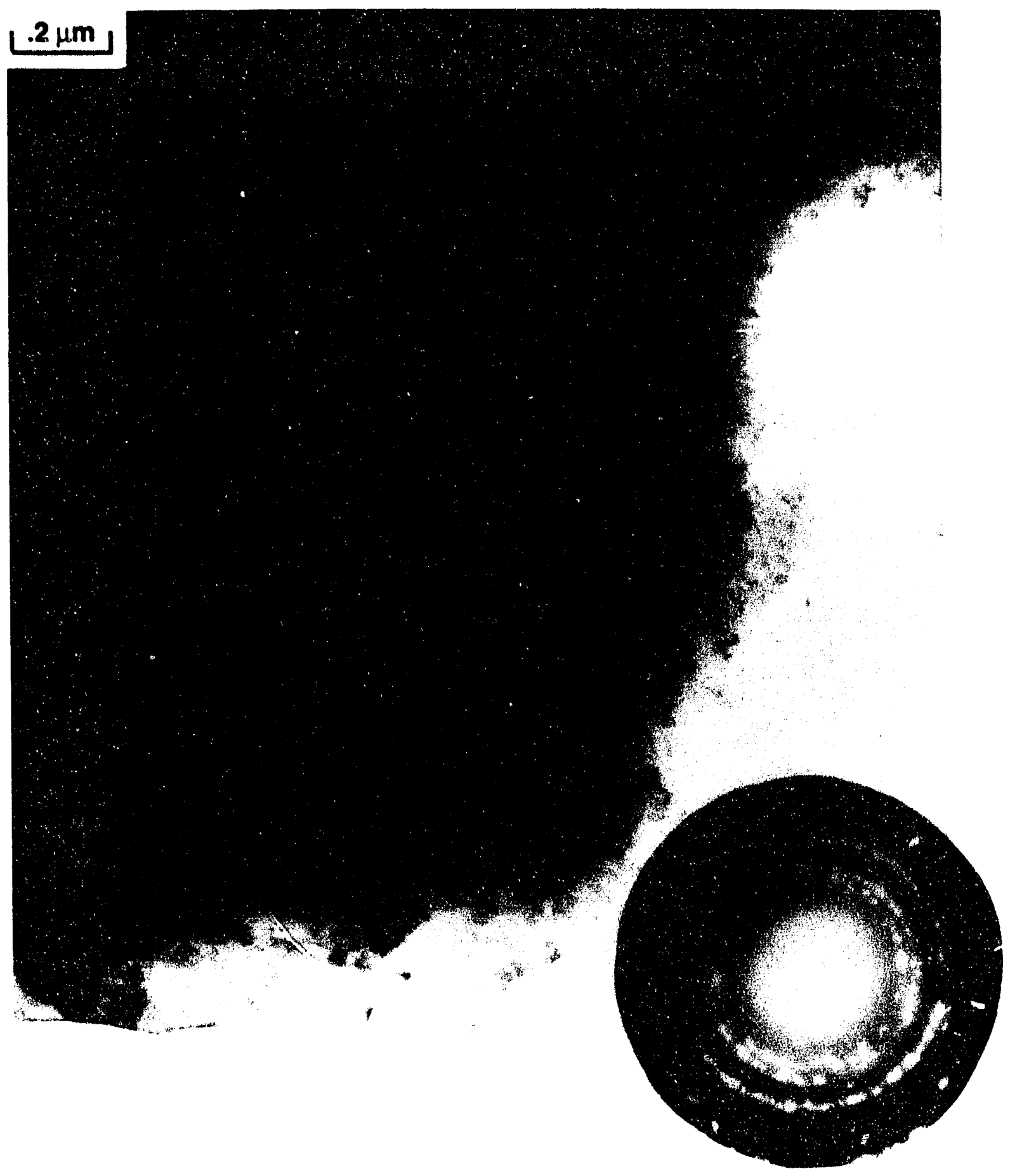

Fig. 8.2-3. Interior of single crystal cube showing typical polycrystalline structure. 


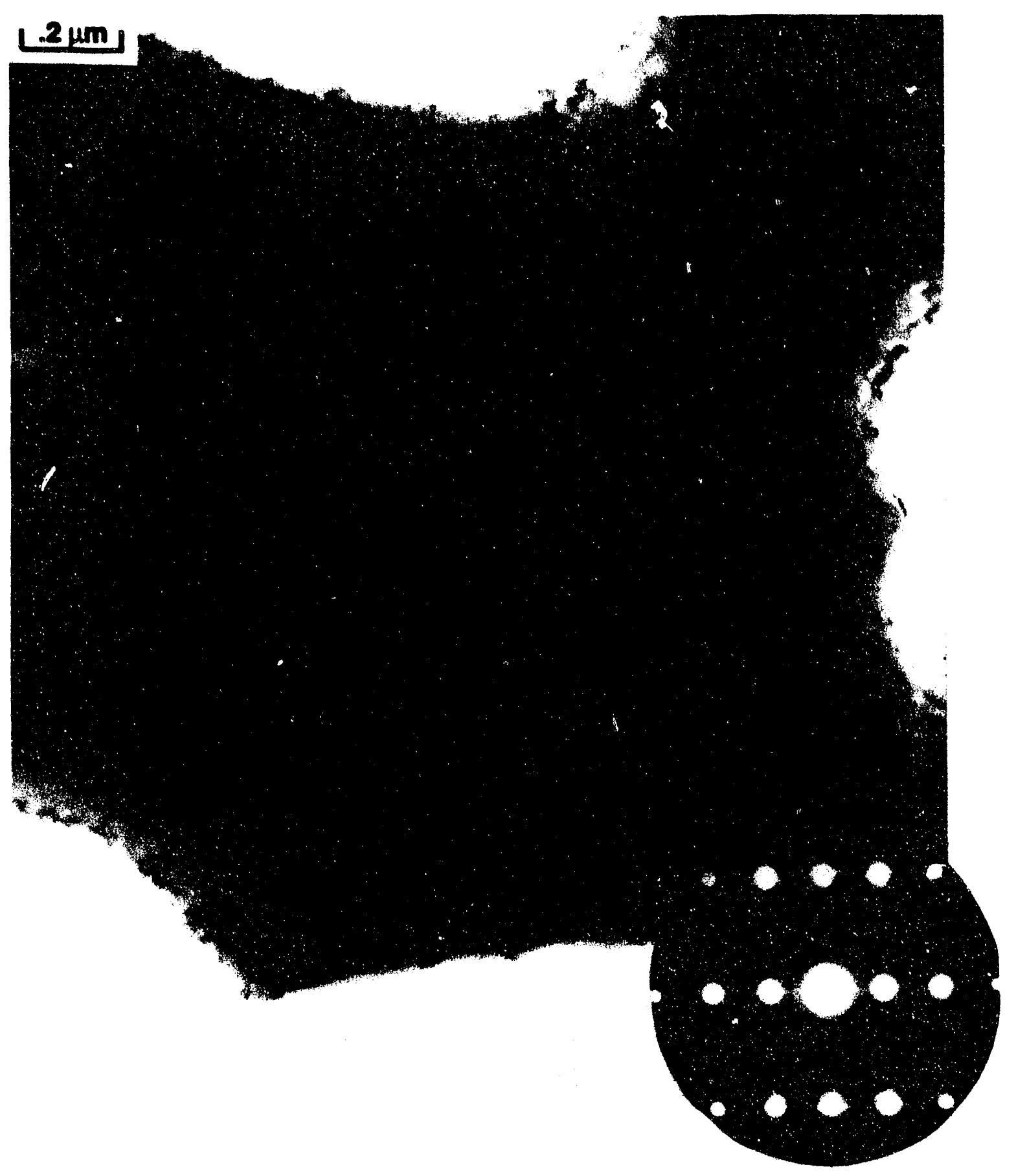

Fig. 8.2-4. Near surface region of cube revealing single-crystalline structure. 


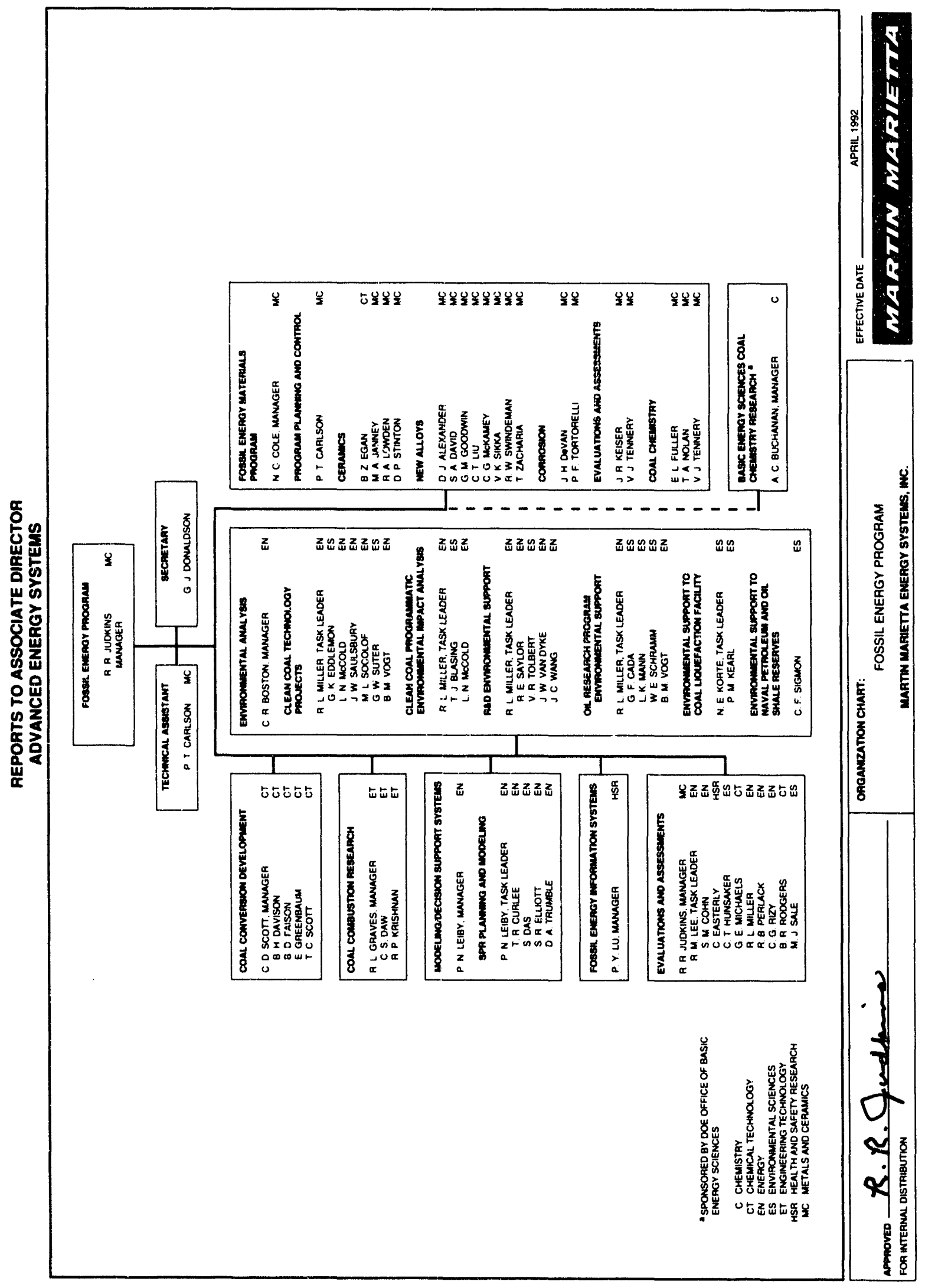




\section{INTERNAL DISTRIBUTION}

T. M. Besmann

C. R. Boston

A. C. Buchanan

P. T. Carlson (2)

N. C. Cole

D. F. Craig

C. S. Daw

J. H. DeVan

B. D. Faison

W. Fulkerson

E. L. Fuller, Jr.

R. K. Genung

R. L. Graves

E. Greenbaum

J. D. Griffin

R. R. Judkins (6)

J. R. Keiser

R. P. Krishnan
R. M. Lee

P. N. Leiby

R. A. Lowden

C. G. McKamey

R. L. Miller

C. D. Scott

S. A. Sherrow

S. P. N. Singh

J. H. Stewart, Jr.

D. P. Stinton

R. W. Swindeman

V. J. Tennery

Central Research Library (2)

Document Reference Section

Laboratory Records Department (2)

Laboratory Records, ORNL - RC

M\&C Records Office (3)

ORNL Patent Section

\section{EXTERNAL DISTRIBUTION}

M. Green

ABB LUMMUS CREST

1515 Broad St.

Bloomfield, NJ 07003

S. C. Weiner

AIR PRODUCTS AND CHEMICALS

7201 Hamilton Blvd., P.O. Box 538

Allentown, PA 18105

W. A. Ellingson

ARGONNE NATIONAL

LABORATORY

9700 S. Cass Avenue

Argonne, IL 60565-4838
C. D. Livengood

ARGONNE NATIONAL

LABORATORY

9700 S. Cass Avenue, Bldg. 362/2A

Argonne, IL 60439

D. K. Schmalzer

ARGONNE NATIONAL

LABORATORY

9700 S. Cass Avenue

Argonne, IL 60439

J. H. Oxley

BATTELLE COLUMBUS

LABORATORIES

505 King Avenue

Columbus, OH 43201 
J. M. Chilton

BETHLEHEM STEEL CORPORATION

Homer Research Laboratories

Bethlehem, PA 18016

G. Twizell

BRITISH GAS plc

Westfield Development Centre

Cardenden

Fife, Scotland KY5OHP

Tom Butcher

BROOKHAVEN NATIONAL LABORATORY

Bldg. 475

Upton, NY 11973

G. Morales-Calvo

CIEMAT (Energetic, Environment and Technological Research Center)

Programa Procesos Mineralurgicos

Avda, Complutense

22 Madrid 28040 Spain

E. Tilley-Hinkle

COAL AND SYNFUELS

TECHNOLOGY

1401 Wilson Blvd., Suite 900

Arlington, VA 22209

R. A. Wolfe

COAL TECHNOLOGY CORP.

103 Thomas Rd.

Bristol, VA 24201

R. E. Wright

COAL TECHNOLOGY CORP.

103 Thomas Rd.

Bristol, VA 24201

F. P. Burke

CONSOLIDATION COAL CO.

R\&D Department

4000 Brownsville Road

Library, PA 15129
D. G. Nichols

CONSOLIDATION COAL CO.

R\&D Department

4000 Brownsville Road

Library, PA 15129

S. B. Alpert

ELECTRIC POWER RESEARCH

INSTITUTE

P.O. Box 10412

3412 Hillview Avenue

Palo Alto, CA 94303

D. M. Golden

ELECTRIC POWER RESEARCH

INSTTTUTE

P.O. Box 10412

3412 Hillview Avenue

Palo Alto, CA 94303

J. Stringer

ELECTRIC POWER RESEARCH

INSTITUTE

P.O. Box 10412

3412 Hillview Avenue

Palo Alto, CA 94303

H. Weisenfeld

ENERGETICS, INC.

7164 Gateway Dr.

Columbia, MD 21046

K. T. Janes

ENVIRONMENTAL PROTECTION AGENCY

Global Warming Control Div. (MD-63)

Research Triangle Park, NC 27711

Y.C.L. Susan Wu

ERC, INCORPORATED

P. O. Box 417

Tullahoma, TN 37388

M. L. Gorbaty

EXXON RESEARCH \&

ENGINEERING CO.

Route 22 East, Clinton TWP

Annadale, NJ 08801 
Heidrun Barnert-Wiemer

FORSCHUNGS ZENTRUM JÜLICH GmbH

Institute for Chemical Technology

Postfach 1913

D-5170 Jülich, Germany

Martin Novack

GENERAL APPLIED SCIENCE LABS

77 Raynor Ave.

Ronkonkoma, NY 11779

J. A. Todd

ILLINOIS INSTITUTE OF TECHNOLOGY

Dept. Metallurgical \& Materials Engr.

Chicago, IL 60616

P. A. Lowe

INTECH, INC.

11316 Roven Drive

Potomac, MD 20854-3126

Maury Saddy

INTER-UHDE ENGENHARIA

OWIMICA LTD

Rua Pedro Americo 32-25 Andar

Sao Paulo, SP 01045

R. L. Phen

JET PROPULSION LABORATORY

4800 Oak Grove Drive - MS 79-21

Pasadena, CA 91020

M. H. Van de Voorde

JOINT RESEARCH CENTRE OF THE EUROPEAN COMMUNTTIES

Westerduinweg 3, P.O. Box 2

1755 ZG Petten, The Netherlands

S. T. Viscontini

MOBL RESEARCH \&

DEVELOPMENT CORPORATION

Engineering Department

P. O. Box 1026

Princeton, NJ 08540
J. P. Gyekenyesi

NASA LEWIS RESEARCH CENTER

21000 Brookpark Road (MS 6-1)

Cleveland, $\mathrm{OH} 44135$

S. R. Levine

NASA LEWIS RESEARCH CENTER 21000 Brookpark Road

Cleveland, OH 44135

S. J. Dapkunas

NATIONAL INSTITUTE OF STANDARDS AND TECHNOLOGY

Materials Building, A259

Gaithersburg, MD 20899

S. Hirano

NEW ENERGY AND INDUSTRIAL TECHNOLOGY DEVELOPMENT ORGANIZATION

Sunshine 60 Bldg., P.O. Box 1151

Higashi-Ikebukuro, Toshima-Ku

Tokyo, 170 Japan

T. Fukumizu

NEW ENERGY AND INDUSTRIAL TECHNOLOGY DEVELOPMENT ORGANIZATION

1800 K Street, NW, Suite 924

Washington, DC 20006

H. T. Burn

OAK RIDGE INSTITUTE FOR SCIENCE AND EDUCATION

P. O. Box 117

Oak Ridge, TN 37831-0117

J. B. O'Hara

RALPH M. PARSONS COMPANY

100 W. Walnut St.

Pasadena, CA 91124

Aksel Olsen

RISOE NATIONAL LABORATORY

P.O. Box 49

Roskilde 4000, Denmark 
S. McNulty

SHELADIA, INC.

Suite 100, 15825 Shady Grove Rd.

Rockville, MD 20850

G. Sorell

G. SORELL CONSULTING SERVICES

49 Brookside Terrace

North Caldwell, NJ 07006

J. H. Laue

SRS TECHNOLOGIES

990 Explorer Blvd., NW

Huntsville, AL 35806

Herman Research Laboratory Library

STATE ELECTRICITY COMMISSION OF VICTORIA

Howard Street

Richmond, Victoria, 3121, Australia

C. M. Huang

TENNESSEE VALLEY AUTHORITY

Research \& Development

MR 3A

Chattanooga, TN 37402-2801

Harry Cheung

UNION CARBIDE INDUSTRIAL GASES, INC.

Linde Division

P.O. Box 44, 175 East Park Drive

Tonawanda, NY 14151

Gilbert Kirsch

UNIVERSITE DE METZ

Laboratoire de Chimie Organique

Faculty des Sciences

Ile du Saulcy 57

Metz, France

O. J. Hahn

UNIVERSITY OF KENTUCKY

Mechanical Engineering Department

Lexington, KY 40506-0046
I. Wender

UNIVERSITY OF PITTSBURGH

1249 Benedum Hall

Pittsburgh, PA 15261

K. N. Strafford

UNIVERSITY OF SOUTH

AUSTRALIA

Department of Metallurgy

The Levels SA 5095, Australia

K. Fuhrmann

VEBA OEL

P. O. Box 45

4650 Gelsenkirchen-Buer, W. Germany

D. H. Archer

WESTINGHOUSE ELECTRIC CORP.

114 Kentzel Road

Pittsburgh, PA 15237-2816

D. L. Keairns

WESTINGHOUSE SCIENCE AND

TECHNOLOGY CENTER

1310 Beulah Road

Pittsburgh, PA 15235

N. Swift

DEPARTMENT OF ENERGY

Chicago Operations Office

9800 S. Cass Ave.

Argonne, IL 60439

D. C. Cicero

DEPARTMENT OF ENERGY

Morgantown Energy Technology Center P.O. Box 880

Morgantown, WV 26505

M. R. Ghate

DEPARTMENT OF ENERGY

Morgantown Energy Technology Center

P.O. Box 880

Morgantown, WV 26505 
J. S. Halow

DEPARTMENT OF ENERGY

Morgantown Energy Technology Center

P.O. Box 880

Morgantown, WV 26505

N. T. Holcombe

DEPARTMENT OF ENERGY

Morgantown Energy Technology Center

P.O. Box 880

Morgantown, WV 26505

W. R. Miller

DEPARTMENT OF ENERGY

Morgantown Energy Technology Center

P.O. Box 880

Morgantown, WV 26505

J. E. Notestein

DEPARTMENT OF ENERGY

Morgantown Energy Technology Center

P.O. Box 880

Morgantown, WV 26505

J. S. Wilson

DEPARTMENT OF ENERGY

Morgantown Energy Technology Center

P.O. Box 880

Morgantown, WV 26505

J. Mosquera

DEPARTMENT OF ENERGY

Naval Reactors, NE-60

Crystal City, Bldg. N.C.-2

Washington, DC 20585

Deputy Assistant Manager for Energy

Research and Development

DEPARTMENT OF ENERGY

Oak Ridge Operations Office

P.O. Box 2008

Oak Ridge, TN 37831-6269

E. E. Hoffman

DEPARTMENT OF ENERGY

Oak Ridge Operations Office

P.O. Box 2008

Oak Ridge, TN 37831-6269
D. J. Beecy

DEPARTMENT OF ENERGY

Office of Fossil Energy, FE-13

1000 Independence Avenue

Washington, DC 20545

R. J. Braitsch

DEPARTMENT OF ENERGY

Office of Fossil Energy, FE-13

1000 Independence Avenue

Washington, DC 20545

J. P. Carr

DEPARTMENT OF ENERGY

Office of Fossil Energy, FE-14

1000 Independence Avenue

Washington, DC 20545

W. Fedarko

DEPARTMENT OF ENERGY

Office of Fossil Energy, FE-232

1000 Independence Avenue

Washington, DC 20545

H. N. Giles

DEPARTMENT OF ENERGY

Office of Fossil Energy, FE-442

1000 Independence Avenue

Washington, DC 20545

F. M. Glaser

DEPARTMENT OF ENERGY

Office of Fossil Energy, FE-14

1000 Independence Avenue

Washington, DC 20545

D. Gray

DEPARTMENT OF ENERGY

Office of Fossil Energy, FE-431

1000 Independence Avenue

Washington, DC 20545

A. W. Hemenway

DEPARTMENT OF ENERGY

Office of Fossil Energy, FE-24

1000 Independence Avenue

Washington, DC 20545 
R. L. Kane

DEPARTMENT OF ENERGY

Office of Fossil Energy, FE-13

1000 Independence Avenue

Washington, DC 20545

\section{F. A. Leone}

DEPARTMENT OF ENERGY

Office of Fossil Energy, FE-35

1000 Independence Avenue

Washington, DC 20545

\section{J. J. Pyrdol}

DEPARTMENT OF ENERGY

Office of Fossil Energy, FE-13

1000 Independence Avenue

Washington, DC 20545

P. C. Scott

DEPARTMENT OF ENERGY

Office of Fossil Energy, FE-14

1000 Independence Avenue

Washington, DC 20545

T. B. Simpson

DEPARTMENT OF ENERGY

Office of Fossil Energy, FE-231

1000 Independence Avenue

Washington, DC 20545

M. I. Singer

DEPARTMENT OF ENERGY

Office of Fossil Energy, FE-30

1000 Independence Avenue

Washington, DC 20545

H. E. Thomas

DEPARTMENT OF ENERGY

Office of Fossil Energy, FE-33

1000 Independence Avenue

Washington, DC 20545

G. E. Voelker

DEPARTMENT OF ENERGY

Office of Fossil Energy, FE-23

1000 Independence Avenue

Washington, DC 20545
G. F. Wheeler

DEPARTMENT OF ENERGY

Office of Fossil Energy, FE-231

1000 Independence Avenue

Washington, DC 20545

N. F. Barr

DEPARTMENT OF ENERGY

Office of Health and Environmental

Research, ER-72

Washington, DC 20585

F. J. Wobber

DEPARTMENT OF ENERGY

Office of Health and Environmental

Research, ER-75

14 Goshen Ct.

Gaithersburg, MD 20882-1016

A. L. Baldwin

DEPARTMENT OF ENERGY

Pittsburgh Energy Technology Center

P.O. Box 10940

Pittsburgh, PA 15236

S. W. Chun

DEPARTMENT OF ENERGY

Pittsburgh Energy Technology Center

P.O. Box 10940

Pittsburgh, PA 15236

R. C. Dolence

DEPARTMENT OF ENERGY

Pittsburgh Energy Technology Center

P.O. Box 10940

Pittsburgh, PA 15236

J. L. Hebb

DEPARTMENT OF FNERGY

Pittsburgh Energy Technology Center

P.O. Box 10940

Pittsburgh, PA 15236

J. D. Hickerson

DEPARTMENT OF ENERGY

Pittsburgh Energy Technology Center

P.O. Box 10940

Pittsburgh, PA 15236 
J. J. Lacey

DEPARTMENT OF ENERGY

Pittsburgh Energy Technology Center

P.O. Box 10940

Pittsburgh, PA 15236

S. R. Lee

DEPARTMENT OF ENERGY

Pittsburgh Energy Technology Center

P.O. Box 10940

Pittsburgh, PA 15236

M. E. Maher

DEPARTMENT OF ENERGY

Pittsburgh Energy Technology Center

P.O. Box 10940

Pittsburgh, PA 15236

S. Rogers

DEPARTMENT OF ENERGY

Pittsburgh Energy Technology Center

P.O. Box 10940

Pittsburgh, PA 15236

J. A. Ruether

DEPARTMENT OF ENERGY

Pittsburgh Energy Technology Center

P.O. Box 10940

Pittsburgh, PA 15236

R. Santore

DEPARTMENT OF ENERGY

Pittsburgh Energy Technology Center

P.O. Box 10940

Pittsburgh, PA 15236

T. M. Torkos

DEPARTMENT OF ENERGY

Pittsburtsh Energy Technology Center

P.O. Box 10940

Pittsburgh, PA 15236

DEPARTMENT OF ENERGY

Office of Scientific and

Technical Information

P. O. Box 62

Oak Ridge, TN 37831
For distribution by microfiche as shown in DOE/OSTI-4500, Distribution Categories UC-122 [Enhanced Oil Recovery (Heavy, Light)], UC-123 (Oil Shale and Tar Sands), UC-125 (Liquid Fuels Research), UC-126 (Petroleum Reserves), and UC-132 (Unconventional Gas Recovery). (10 copies) 

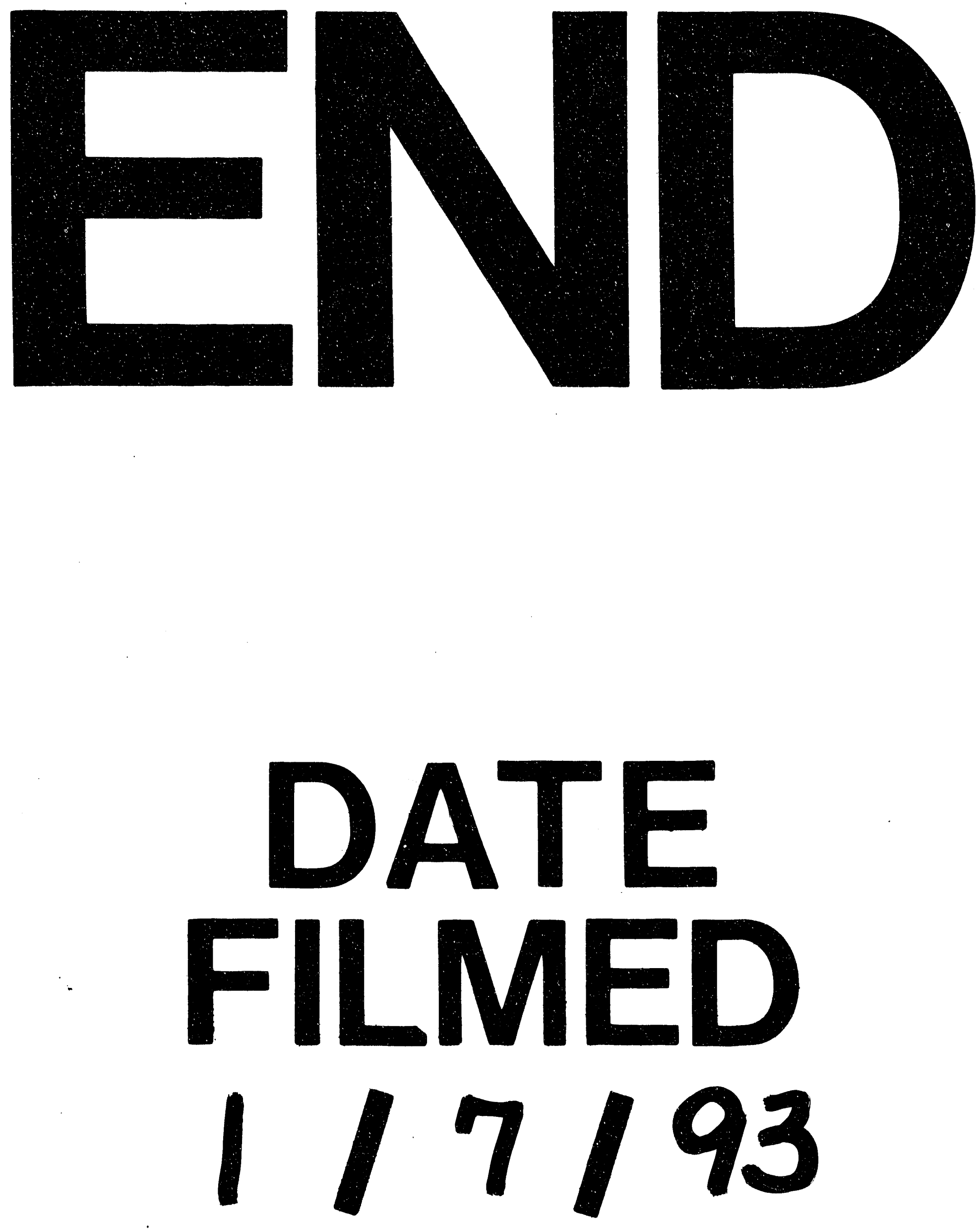
